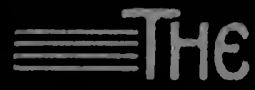

\title{
INTERNATIONAL
}

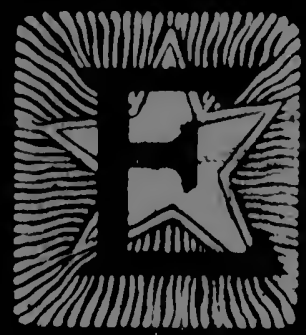




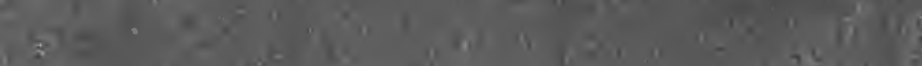

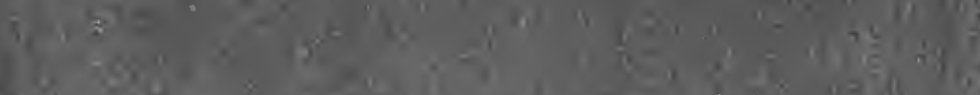

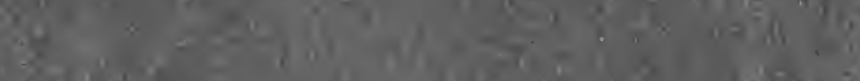

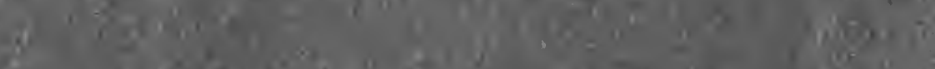

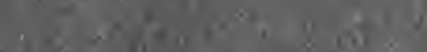

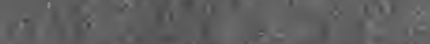

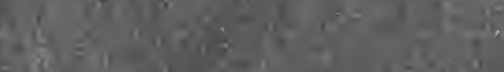

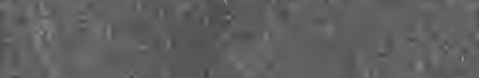

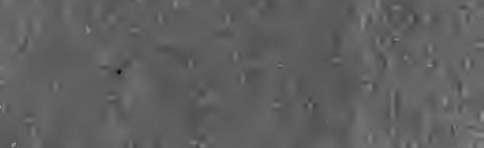

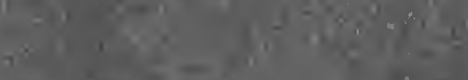
If

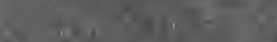

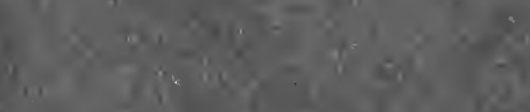

$y=\frac{3}{2}=$

(1)

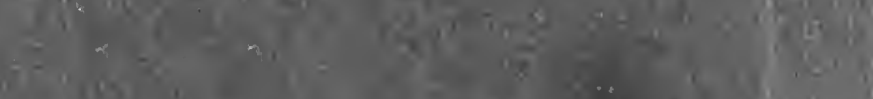
S.

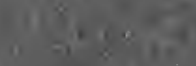
i 1

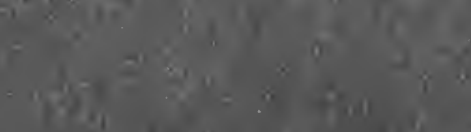
3
8

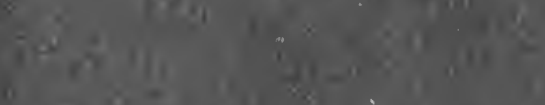

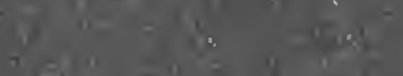

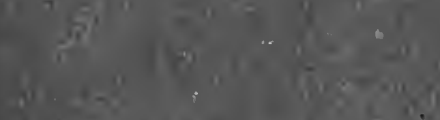

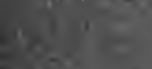

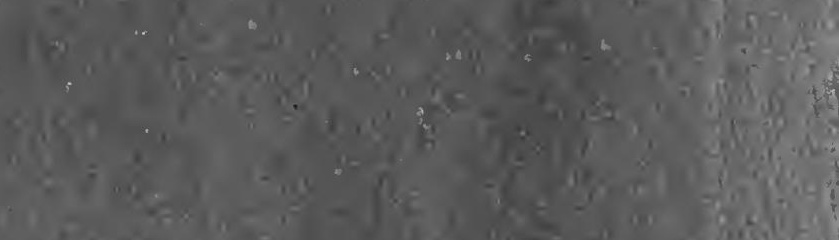

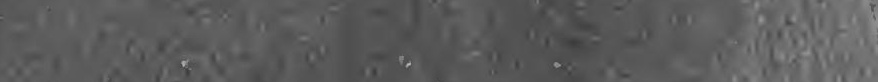

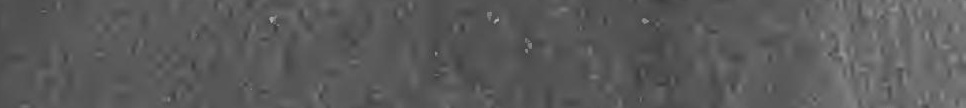

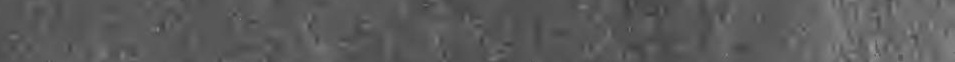

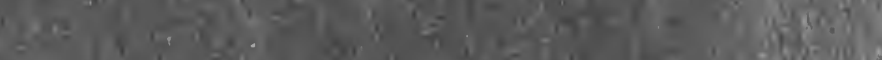

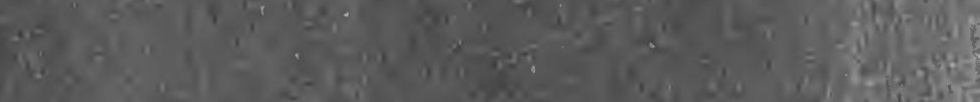

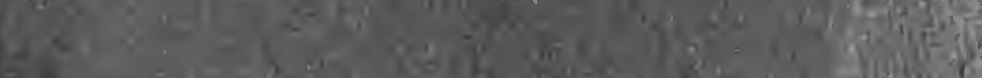

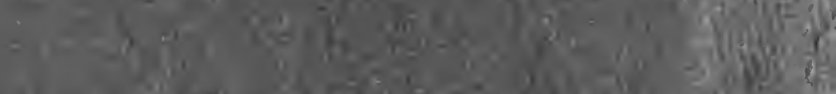

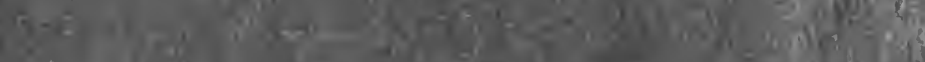

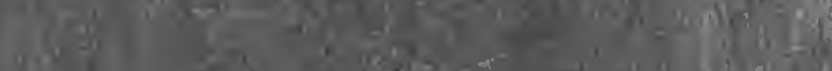




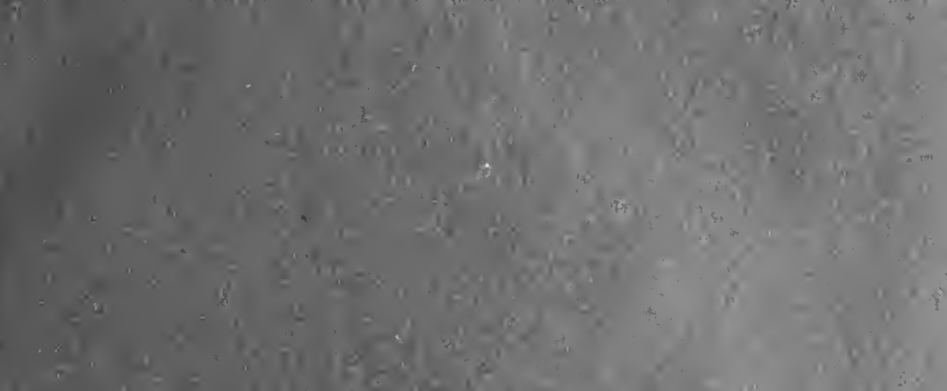

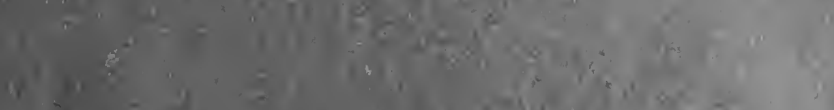

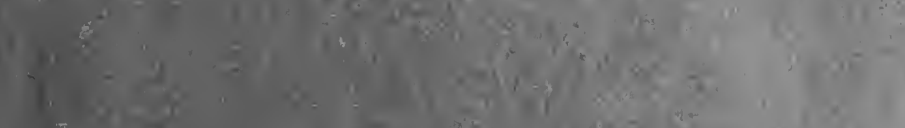

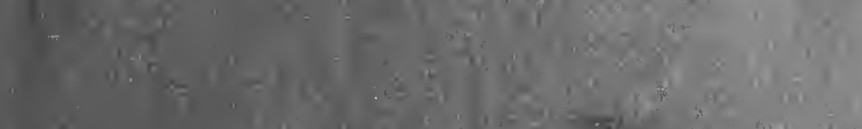

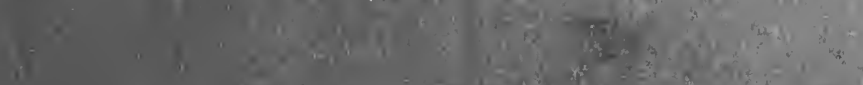

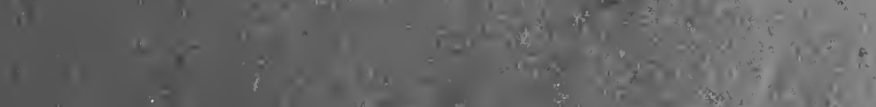

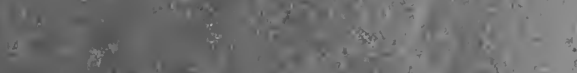

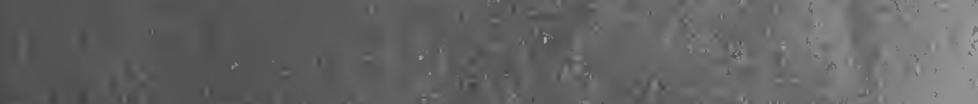

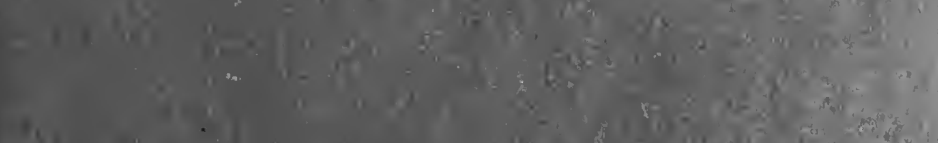

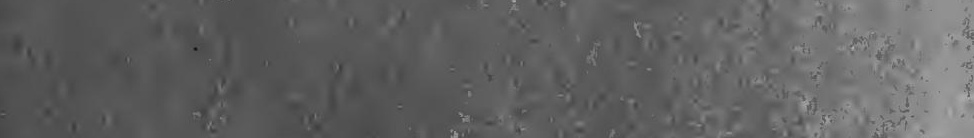

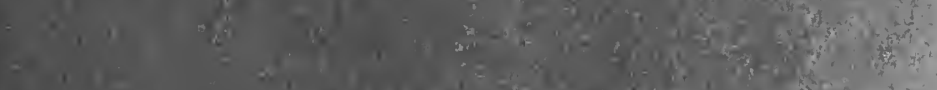

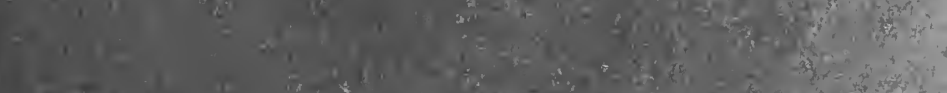

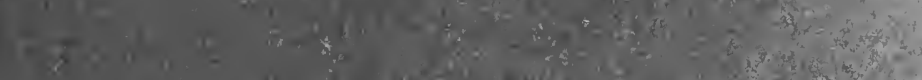

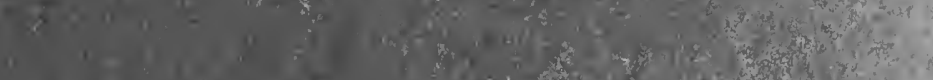

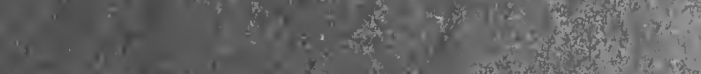

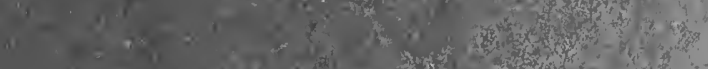

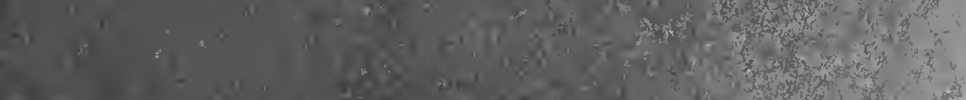

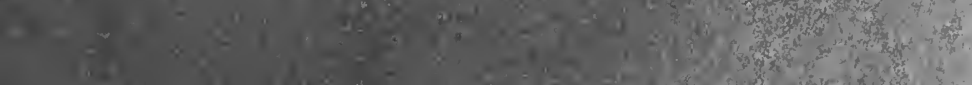

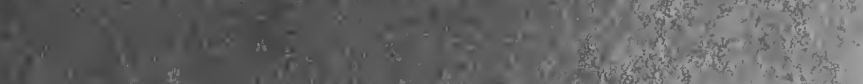

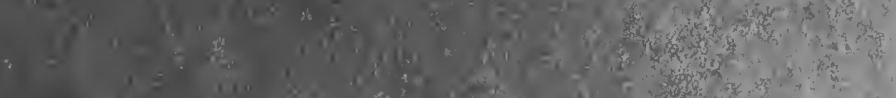

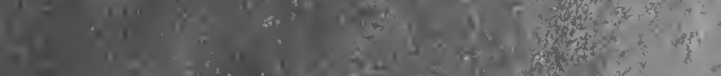

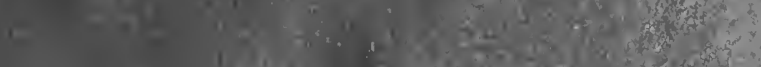

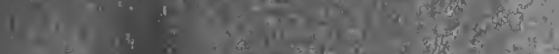

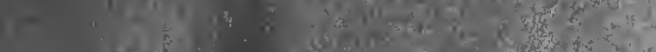



Digitized by the Internet Archive in 2007 with funding from

Microsoft Corporation 



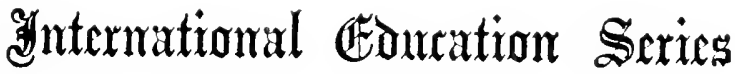

\author{
EDITED BY \\ WILLIAM T. HARRIS, A. M., LL. D.
}

VOLUME LV 


\title{
INTERNATIONAL EDUCATION SERIES.
}

\author{
12mo, cloth, uniform binding.
}

THE INTERNATIONAL EDCCATION SERIES was projected for the pur. 1 pose of bringing together in orderly arrangement the best writings, new and old, upon cducational subjects, and presenting a complcte course of reading and training for teachers generally. It is cdited by Willias T. HARris, LL. D., United States Commisioner of Edncation, who has contribnted for the different volumes in the way of introduction, analysis, and commentary.

1. The Philosophy of Edueation. By JoHank K. F. Rosenkmanz, Doctor of Thcology and Professor of Philosophy, University of Konigsberg. Translated by ANNa C. BRAcketr. Second edition, revibed, with Commentary and complete Analysis. $\$ 1.50$.

2. A History of Education. By F. V. N. PAinter, A. M., Professor of Modern Languages and Literatnre, Roanoke College, Va. \$1.50.

3. Tle Iise and Early Constitution of Universities. WiTH a SCrvey of Mediefal Einucation. By S. S. Lacrie, LL. D., Professor of the Institutes and History of Edncation, University of Edinburgh. $\$ 1.50$.

4. The Ventilation and Warming of School Bulldings. By Gilbert B. Momuson, Tcacher of Physlcs and Chemistry, Kansus City High School. $\$ 1.00$.

5. The Education of Man. By Friedricr Froeber. Translated and annotaled by W. N. Mallmans, A. M., Superintendent of Public Schools, In Porte, Ind. $\$ 1.50$.

6. Elomentary Psychology and Education. By Joskpr Bardwin, A. M., LL. D., author of "The Art of School Managcment." $\$ 1.50$.

;. The Senses and the Will. (Part I of "The MiNd or THE Child.") By W. Preykr, Professor of Physiology in Jena. Transiated by 11. W. Bkow , Tcacher In the State Normal School at Worcester, Mas8. $\$ 1.50$.

8. Iremory: What it is and How to Improve it. By David Kar, F. R.G.S., author of "Educatlon and Educators," etc. \$1.50.

9. The Development of the Intellect. (Part II of "THE MNND of THE Cuild.") By W. Prexke, Professor of Physiology In Jcna. Transiated by II. W. BRown. $\$ 1.50$.

10. How to Study Geography. A Practical Exposition of Mcthods ana Devlces in Tcaching Geography which apply the Principlcs and Plans of Ritter and Gnyot. By Francis W. PARKer, Principal of the Cook County (Illinois) Normal School. 81.50 .

11. Education in the United States: Its Mistory from the Earliest Settlements. By Ricinand G. Boonz, A.M., Profegsor of Pedagogy, Indiana University. $\$ 1.50$.

12. European Schools; OR, Wuat I SAw IN THE Schoolb of Gramany. France, AUbtria, and Switzerland. By L. R. Klem , Ph. D., Principal of the Cincinnatl Technical School. Fully illustrated. $\$ 2.00$.

13. Practical Hints for the Tenchers of Public Schools. By Geores Ifowland, Superintendent of the Chicago Public Schools. \$1.00.

14. Pestalozz: His Life and Work. By Roger DE Gumps. Anthorized Trasielation from the Recond French edition, by J. Rossel., B. A. With an Introduction by Rer. R. H. Quick, M. A. \$1.50.

15. School Supervision. By J. L. Pickakd, LL. D. \$1.00.

16. Higher Education of Women in Europe. By Hefenk Lavez, Berlln. Trunslated and accompanied by coinparative statlstica by L. R. KLKYX. $\$ 1.00$.

17. Easajs on Eduontional Reformers. By ROBERT Herbert Quick, M. A., Trinity College, Cambridgc. Only anthorized edition of the work rewritten in 1800 . \$1.50.

18. A Text-Hook in Pgychology. Ry Jorans Fhie drich Heribart. Trane. lated by MaIKARFT $K$. SMITL. \$1.00.

10. Psychoiogy A pplied to the Art of Tesehing. By Josepa Baldwi, A. M., LL.D. $\$ 1.00$. 
20. Kousseau's Emile; or, Treatiss on Edocamox. Translated and annotated by W. H. YAYNE, Ph. D., LL. D. $\$ 1.50$.

21. The Moral Instruction of Children. By FeLIx ADLer. $\$ 1.60$.

22. English Education in the Elementary and Secondary Schools. By Isac Sharpless, LL. D., President of Haverford College. $\$ 1.00$.

23. Cducation from a National Standpoint. By ALFneD Focrlıtz. \$1.50.

24. Mental Development of the Child. By W. PRerim, Professor of Physiology in Jena. Translated by H. W. BRows. \$1.00.

5. How to Study and Teach History. By B. A. HiNsdalz, Ph. D., LL. D., University of Michigan. \$1.50.

26. Syinbolic Education. A Commentaky on Frokbel's "Mother-Plat." By Susan E. Blow. \$1.50.

27. Systematic Science Teaching. By EDward Gardnier How E. \$1.50.

28. The Education of the Greek People. By Thomas Dandon. \$1.50.

29. The Evolution of the Massachusetts Public-School System. By G. H. MagtiN, A. M. $\$ 1.50$.

30. Pedagogics of the Kindergarten. By Friedrich Froeber. \$1.50.

31. The Mottoes and Commentaries of Friedrich Froebel's MotherPlay. By Susan E. Blow and Henrietta R. Eliot. \$1.50.

32. The Songs and Music of Froebel's Mother-Play. By Sosan E. BLow. \$1.50.

33. The Psychology of Number. By James A. Mcleluak, A. M., and JoHN DEW EY, Ph. D. $\$ 1.50$.

34. Teaching the Language-Arts. By B. A. Hnsdale, LL. D. $\$ 1.00$.

35. The Intellectual and Moral Development of the Child. Part I. By Gabriel CoMpayre. Translated by MART E. Wilson. $\$ 1.50$.

36. Herbart's A B C of Sense-Perception, and Introductory Works. By WILILM J. ECKOFF, Pd. D., Pb. D. \$1.50.

37. Psychologic Foundations of Education. By WiLluM T. Harris, A. M., LL. D. $\$ 1.50$.

88. The School System of Ontario. By the Hon. Grorge W. Ross, LL. D., Mivister of Education for the Province of Ontario. \$1.00.

39. Principles and Practice of Teaching. By Jambs JohonNor. $\$ 1.50$.

40. School Management and Methods. By Josepr BaLdwn. \$1.50.

41. Froebel's Educational Laws for all Teachers. By JAxEs L. HugHEs, Inspector of Schools, Toronto. \$1.50.

42. Bibliography of Education. By Wizr. S. Monrok, A. B. $\$ 2.00$.

43. The Study of the Child. By A. R. TAYLOR, Ph. D. $\$ 1.50$.

44. Fducation by Development. By Friedrich Frokbel. Translated by JosEPHINE JARvis. \$1.50.

45. Letters to a Mother. By Susan E. Buow. $\$ 1.50$.

4. Montaigne's The Education of Children. Translated by L. E. FroTOR, Ph. D. \$1.00.

7. The Secondary School System of Germany. By Fampiniox E. Boltox. \$1.50.

4. Advanced Elementary Science. By EDward G. Hows. $\$ 1.50$.

49. Dickens as an Educator. Bz JA3rs L. Hughes. \$1.50.

B. Principles of Fducation Practically Applied. By Jaxrs M. GrekNwoov. Revised. $\$ 1.00$. 
51. Student Life and Customs. By Henry D. Sheldon, Ph. D. $\$ 1.20$ net. 52. An Ideal School. By Preston W. Sка всH. $\$ 1.20$ net.

53. Later Infancy of the Child. By Gabriel Compayre. Tranglated by Mary k. Willsox. Hart II of Vol. 35. \$1.20 net.

54. The Educational Foundations of Trade and Industry. By Fabian W ARE. \$1.20 net.

55. Genetic Psychology for Teachers. By Charleg H. Judd, Ph. D. $\$ 1.20$ net. OTHER VOLUMES IN PREPARATION.

D. APPLETON AND COMPANY, NEW YORK. 


\title{
J g2ag.
}

INTERNATIONAL EDUCATION SERIES

\section{GENETIC PSYCHOLOGY FOR TEACHERS.}

\author{
BY \\ CHARLES HUBBARD JUDD, Ph. D. (Leipzia)
}

INSTRUCTOR IN PSYCHOLOGY

YALE UNIVERSITY

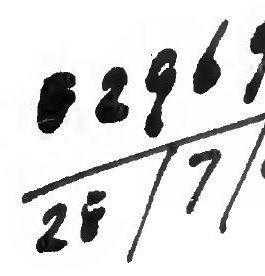

NEW YORK

D. APPLETON AND COMPANY

1903 


$$
\Rightarrow g
$$

Copyright, 1903,

BI D. APPLETON AND COMPANY.

Published March, 1903

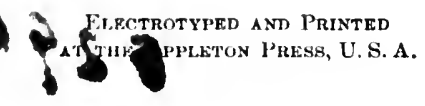

$\therefore$ 


\section{EDITOR'S PREFACE}

The publishers take pleasure in offering to the readers of the International Education Series a valuable contribution drawn from the sources of experimental psychology. It has becn preparcd with good taste and sound judgment, and it is believed that all of the chapters will be read with interest and profit by those connected in any way with the work of teaching.

Natural science has been remodeled in the past fifty years through the influence of the idea of evolution as interpreted by Darwin and his disciples. For a very long period seicnce has meant the inventorying of facts and the organization of them into a systcm in such a manner that each fact throws light on all the other facts of its group. The idea of evolution-brings into this older conception of science the idea of progressive development. Under the most advanced interpretation, science is a history of the progressive conquest of nature, first for purposes of life and second for purposes of conscious bcings. The second of these purposes obviously brings the doctrine of evolution into close rclation with education. Doctor Judd, in his excellent remarks on adaptation in Chapter IV (page 
106), quotes Professor Minot: "Vital funetions have a purpose-the maintenanee of the individual or the raee in the environment. The entire evolution of plants and animals is essentially the evolution of means of adjustment of the organism to external eonditions."

Adjustment has two sides. In one respeet it relates to the modifieation effeeted in the individual in order to suit itself to the external conditions of its environment. In the other respeet, it relates to the modifieations effeeted in the environment to suit it to the individual-i. e., to the self-aetive being who desires to use it for food, elothing, or shelter, or some other purpose eonneeted with its well-being. The mole aets on the earthwornis and on their habitat, but he modifies himself also. In the statement of Darwin the doetrine of natural seleetion seems in some respeets to eelipse the doetrine of self-aetivity whieh furnishes the energy both of the adaptation of the self and of the environment. Emerson's expression of the ideal of evolution (whieh, by the way, was written some time before Darwin's ehief work) puts it thus:

Striving to be man the worm

Mounts through all the spires of form.

Individual efforts at adaptation beeome soeial through heredity; that is to say, they go out from the individual to the speeies through heredity. But, in the more advaneed stages of life and mind, eduertion beeomes the most important faetor of progress. Doetor Judd says: "The individual gets through innitation a kind of soeial inheritance that is different 
from the structural inheritance. Imitation has accordingly been called the means of social heredity" (page 108). This doctrine is a very fundamental one and throws great light on everything connected with education.

Every teacher will be delighted with the exposition of this matter in the fourth chapter. The mole hunts earthworms and proceeds by minute steps of conceiving a purpose, and of realizing this purpose, until it produces an hereditary change in its physique. The disuse of organs causes their diminution in the individual in the course of its own life, and after several generations the effect becomes visible as an inheritance, as a diminution or utter extinction of eyesight.

The most wonderful thing about Darwin's theory is that it makes introspection a power in the objective world, although Darwin was very reluctant to admit it. The doctrine of evolution sees in nature ${ }^{1}$ a tendency to develop (or "select") such beings as possess internality and energize to realize their ideals. It is curious to note that this movement in science (Darwinian) begins by the utter repudiation of what is called teleology. It sets aside the old doctrine of design which looks for marks of external adaptation of nature to ulterior spiritual uses. But it notes everywhere the manifestation of instinct, appetite, desire, feeling, blind

1 "Nature," said Plotinus (Ennead, iii, viii, iii), "is Philotheamon, or greedy of beholding itself. A blind tendency in nature to develop some ideal implies as its logical condition a completely realized ideal in the absolute, the first principle of the world, through which nature is given its being." (Compare Psy. chological Foundations of Education, p. 21.) 
tendeneies or impulses which indieate self-movement or self-aetivity in some shape.

A plant has the power of digestion or assimilation. It is able to seize on external, inorganic objects and strip off their forms to eonrert them into regetable cells and add them to its own structure, thereby building with them its own organism. It multiplies itself into separate individualities through this process of the formation of external matter into eells of its own, each cell inspired with a low form of self-activity. But the animal shows a so much higher form of internal life, being able to form representations within itself of its environment, and to will motions in its body based on its representations, that we begin to see how nature is striving to become introspective in its "natural seleetion" and its "survival of the fittest."

Besides his elear exposition of the principles of evolution, Doctor Judd has written many elear and helpful eriticisms of existing methods and devices employed in the schoolroom.

An excellent criticism on Colonel Parker's method of teaching arithmetic-the method which insists on limiting the study of arithmetic to incidental use in eonnection with other branches of study-is to be found in Chapter IX. Also a quotation from Wundt at the end of the same chapter deserves the eareful attention of those disciples of ehild-study who hare not yet fully mastered the prineiples of the science.

"It is an error," says Wundt, " to hold, as is sometimes held, that the mental life of adults can never be fully understood except through the analysis of the child's mind. The exaet opposite is the true position 
to take. Since in the investigation of children and of savages, only objective symptoms are in general available, any psychological interpretation of these symptoms is possible only on the basis of mature adult introspection which has been carried out under experimental conditions. For the same reasons, it is only the results of observations of children and savages which have been subjected to a similar psychological analysis, which furnish any proper basis for conclusions in regard to the nature of mental development in general."

W. T. HARris.

Washington, D. C., March 2, 1903. 



\section{AUTHOR'S PREFACE}

TrE experiences of a number of years spent in teaching psychology to classes of teachers in New York and Cincinnati have fully convinced me that the great majority of teachers gain much by a careful scientific study of mental life. To be sure, there are teachers who are misled into a sentimental or superficial way of studying the child's mind, and there are certain forms of what is known as scientific psychology which have nothing to do with life of any sort and can therefore be of no value to teachers. These facts are enough to make one shrink from asserting unqualifiedly that teachers should study psychology. We can, however, on these very grounds, assert with the greater emphasis that teachers should be given some insight into scientific methods and results in order to save them from sentimentality and vagueness, and in order to allow them to judge for themselves what facts of mental life are important for the work of education and what are not.

It is hoped that this book will serve in some measure to acquaint those for whom it is prepared with the spirit and results of the scientific study of mental development. To the critical student of science much of the material presented will not be at all new. I have borrowed freely, giving credit where I have reproduced matter which is not common property or not material of my own. In a number of the chapters 
I have repeated from articles of my own which appeared in the Journal of Pedagogy, the Psychologieal Review, and the Philosophische Studien. I am under obligations to the editors of these journals for permission to reproduee here the substance of these earlier articles. The mode of presentation whieh has been followed throughout the book is that of a very informal leeture diseussion. After making this general explanation, I trust that it will be unneeessary to offer any special apologies for the frequent appearanee of the first and seeond pronouns. Teehnieal terms have been avoided as far as possible, and where they have been introdueed, some explanation has always accompanied each term at the time of its first appearanee.

In the final revision of the work for publication, I have been greatly aided by the eriticisms and suggestions of my eolleagues and friends, Professor Sneath, Dr. Rowe, and Dr. MeAllister. One other obligation whieh I wish to aeknowledge very fully is my obligation to my students, many of whom have been teaehers. From their suggestions I have learned mueh sound psyehology and pedagogy, and through tlieir eooperation the conelusions here embodied have been worked out. The present form of the diseussions has been put to the practical test of presentation to a body of teaehers. The teaehers of Green County, Ohio, went through the book with me in very much its present form. Their aeeeptanee of the prineiples and applications here advoeated has encouraged me in deciding to seek a larger audienee.

C. H. J.

New Haven, Conn., March, 1903. 


\section{CONTENTS}

chapter

PAGE

I.-TEACHER-STUDY, ITS SCOPE AND AIMS • • • • 1

II.-How EXPERIENCES ARE CONSOLIDATED INTO INTERPRETATIONS OF MEANING • • • • • • 36

III.-The ORIGIN OF SOME OF OUR EDUCATIONAL IDEALS • 69

IV.-THE NEW IDEALS OF DEVELOPMENT • • • • • 98

V.-INDIVIdUALITY, ADAPTATION, AND EXPRESSION • • 129

VI.-THE TEACHER'S WRITING HABIT • • • • . 161

VII.-RACIAL AND INDIVIDUAL DEVELOPMENT IN WRITING • 197 VIII.-THE PROCESS OF READING • • • • • • • $\mathbf{2 3 6}$

IX.-ThE IDEA OF NUMBER . • . • • • . . 265

X.-Sone limitations of OUR NatURE AND SUMMaries OF CHAPTERS • • • • • • • • . 297

INDEX • • . . . . . . . . 323

xiii 



\section{GENETIC PSYCHOLOGY FOR TEACHERS}

\section{CHAPTER I}

\section{TEACHER-STUDY, ITS SCOPE AND AIMS}

There is a kind of flattering sympathy with which it is not uncommon for those who speak to teachers to introduce their remarks. "You are an overworked class; you are the victims of an ignorant lack of appreciation on the part of the public; you ought not to be made to think more than five hours a day at the most, for it is too trying on the nerves of such highly organized human beings." How often have we heard remarks like these addressed to tcachers, and accepted with a sort of sclf-righteous complaisance, exhibited in nods and smilcs of approval or even in outbursts of applause! And how dangerous it would seem to be for any one to come before you with anything but this conventional introduction! I feel compelled, however, to be frank with you and to say to you at once that the discussions which we are to hold, are all based on the fundamental belief that there are large possibilities of productive activity in the lives of teachers, many of which are wasted; that most of us could add many hours to our present periods of mental activity without harm; and, 
finally, that if teachers are not appreciated by the publie, it is very largely the fault of the teachers themselves.

Nor are these unconventional belicfs due to the fact that the speaker is unaequainted with the type of teachers who furnish the secmingly valid basis for the statement that members of our profession are overworked. It has been his lot to know intimately two great eity school systems and a number of smaller systems in which the complete and sudden remodeling of the course of study and the introduction of entirely new modes of administration have put upon the teachers a burden of unusual weight. Under sueh conditions of ehange in the course of study and in the mode of administration one would expect to find, if anywhere, overworked teachers. But if one observes earefully he will find that what so often seenis to be overwork, is nothing but unneeessary and harmful over-worry. The diffieulty is not so much in the fact that teachers have to think and plan, as that they come to their work in a state of mental confusion and exeitement which renders any task difficult. It is not so much that they are asked to take up new studies in the schools, as that they have allowed themsclves to drift into a form of mental life which is not congenial to any kind of innovation. All this means, in brief, if you will allow me to use the terms without any veneering, that we, as teachers, dealing with immature minds day after day, tend to become so self-satisfied and so fixed and dogmatic in our modes of thought and action that we stop growing and begin to get so far behind the times that we do not find it possible to keep up with reform when reform eomes. 
I have made bold to say these things at the very outset in order that we may begin our discussions with a elear reeognition of their spirit and aims. For I should not be here with these statements about the dangers and diffieulties of our professional lives if I did not believe with all eertainty that it is possible to overeome this harmful over-worry and this eonfusion whieh doubles the burden of work. It is possible for teaehers to save themselves from mental stagnation, to advanee day by day, and thus keep paee with our rapidly progressing edueational life. The eondition, however, whieh must be fulfilled in order to attain these desirable ends is that teachers shall eonsider and apply to themselves some of the eommon prineiples of edueation.

Did you never wonder why, in this age when we are studying so eagerly all the faetors of the edueational situation, no one has ever undertaken an exhaustive study of the teaeher? We have a history of edueational systems; we study present-day institutions and their organization; we study ehildren with great eare and with mueh enthusiasm; we take up psyehology and soeiology; but we do not seem to have waked up to the faet that bad order in our elasses is sometimes a problem in teaeher-study instead of ehild-study, that the introduetion of a new subjeet into our sehools is not always a question in soeiology, but is more often a question of seeuring the eooperation of a body of teaehers who, all unknown to themselves, are buried under a mass of traditional ideas.

Now do not have visions of a mass of dry material to be studied in this new seienee of teaeher-study whieh I have brought to your attention, for I am not going to 
suggest that we send out elaborate questionnaires as our first step. I eonfess that when I look over some of the titles of ehild-study investigations, sueh as " Children's lies," "Effeets of weather on ehildren," "What ehildren do out of sehool," ete., I have sometimes thought that it would be only fair for some juvenile vietim of these ehild-study revelations to eompare notes with his fellows on those modes of obseuring faets which are at times employed by teaehers, and whieh parallel ethieally what in ehildren are ealled lies. And if the weather affeets ehildren, and if what children do outside of school affeets their work in sehool, then why might not some of these same relations be assumed to have signifieanee for the older and yet human individuals who eonduet the affairs of the elass-room? Some day the seienee of teacher-study may beeome mature enough and broad enough in its seope to venture on some of these investigations, whieh we now hardly dare to urge too seriously. For the present our range must be more limited. And yet I believe that within this narrower range the study ean be made suggestive, if we will but look at ourselves fairly and frankly, and, having seen ourselves, not turn away and straightway forget what manner of men and women we are, but diligently and daily take up the task of edueating ourselves as earnestly as we take up the task of edueating others.

There is another reason why it is right to urge upon you the importanee of this study whieh we have ealled teacher-study. It is only through an intelligent interest in one's own development that one ean gain a true understanding of the needs of the developing child.

Let me explain a little more fully what I mean. We 
have learned as one of the grcat lessons of our childstudy that children arc not small adults. There are essential diffcrences in nature between children and grown-ups, which make it necessary for us to treat children in a way appropriate to their special needs. Now, the general fact that children are different from ourselves is one which can be more or less fully grasped without any profound study. But the teacher must go further than merely to grasp the general fact. The teacher must be able to understand in detail, first, his own mental characteristics, and secondly, the specific characteristics in which the child differs from himself. This is no casy task, for it is proverbial that by nature we interpret the thoughts of others in the light of our own experiences. If you think thus and so when you hear a certain sound, then you expect, unless your training has shown you the truth, every one else to do the same under the same conditions. It requires some careful study, both of oneself and of others, to realize that thought processes in the presence of the same object may be very different in different individuals. It requires a good deal of the most careful kind of self-study as well as child-study for the teacher to realize anything about how the child before him really thinks and feels.

Some hints as to the way in which children think and feel can be gathered from the few rather vague recollections that come to us of our own childhood's habits and experiences. Indeed, some one will do a great service for child-study if he will gather recollections of this sort more extensively than they have ever been gathered and put them into systematic order. But rccollcctions can give us only hints, and if these were 
the only connceting links between adult mental life and the child's mental life, our knowledge of the child's difficulties in mental growth would be indeed meager. Fortunately there is another bond of connection. Each of us has undeveloped faculties, dormant possibilities, which make us in certain particulars close friends of the child. If, recognizing this, we turn oursclves into both teachers and pupils at once, and watch our own dormant possibilities as they grow and develop, the advantage will be twofold. We shall improve as pupils, and as teachers we shall learn some of the lessons of our art of instruction by seeing how the learner and the teacher may cooperate and how they have difficulty in understanding each other.

Mark you, I do not say that adult education in these undevcloped functions is the exact duplicate of that which should take place in the case of the child. What I do say is, that if you will discover some undeveloped faculty in your own mind and then observe its changes as you pass through the process of education, you will have one of the best experiences on which to base your child-study. For example, I once had a class of teachers who agreed to spend some time and practise in trying to improve their writing. We selected a very narrow line of study. Each of us tried to make the slope of his letters uniform, and to observe closely what the stages of development were. There are very few adults who have given much attention to the development of a uniform slope of their letters. We found this, accordingly, a proper subject to study. The effort to improve gave us, individually and collectively, I am sure, more insight into the attitude which children take in their efforts to 
learn to write, than could have becn acquircd from indefinite quantities of child-study unaided by teacher-study. And so I say we have a right to urge the importance of tcacher-study as a nccessary preliminary to child-study. 'The child's mind is indeed different from our own; if we would realize this fully, we must study the changes through which the learner passes, by direct, first-hand observation in ourselves. We must realize that mental progress never ends, and that at all stages it exhibits certain similarities and follows certain common principles, and we must seek out these principles of development where alone we can come into direct contact with them-namely, in our own expericnces.

Onc does not need to go through any elaborate process of sclf-training in order to understand the mcaning of development. He can find phases of his own experience which indicate that he is indeed a step beyond the child in mental life, but by no means yet at the limit of possible progress. Take as one of the best illustrations of this general fact, the adult recognition of distances and sizes. You see a man coming down the street two blocks away, and you recognize his true size with a fair degree of accuracy. This shows itself in the fact that your visual recognition of him does not have to be changed in any noticeable degree as he comes nearer. For short distances, such as two blocks, the facts which we all know as the facts of perspective do not make it difficult for us to recognize visual size. The result is, that in spite of the fact that the optical image of that man is much smaller at a distance of two blocks than it is at a distance of ten or twenty feet; in spite of the fact that you would have to draw the man much smaller 
if you wanted to represent him as two blocks away than if you wanted to represent him ncar at hand-in spite of these facts, you see him even at the grcater distance in his normal dimensions. Put into other words, this means that you have so fully mastered the significance of this class of cxperiences that you get a fully developed, accurate form of knowlcdge and experience without difficulty, whether the man is near at hand or two blocks away - that is, whether your visual image is large or relatively small. But now increase that two blocks to a mile, or, better still, climb up to the top of a high building and look down at the man. How does he look now? As large as usual? Of course not. Look at him as you will, he looks small. Even your knowledge of the fact that he is of the usual size does not help you. Even the dictum of some learned teacher could not makc that man look as large as usual. The trouble is that our adult consciousness is not used to dealing with men at ranges of a mile, nor is it uscd to dealing with men a hundred feet below us. The man at a distance of two blocks looked natural because he stood quite within the range of our ordinary training in the recognition of visual size. For short distances on level ground we have a developed faculty of recognition, but for long distances, and for comparativcly short distances upward and downward, we have only very limited training. Some onc may be led to ask, At what range does adult recognition of sizc ccasc to be accurate and fully developed? Wc can not answer this question in a general way. Different individuals differ very greatly. The determining factor is the amount of experience. And to make this clcar we may at once appeal to some illus- 
trations, which will at the same time serve to show the value of this teacher-study for the comprehension of the child's mind.

I remember when I was a little boy riding across a high railroad bridge with my father. Down on the flat land at the river level were some laborers. I was much interested in them, they were such little men. I could have held one of them in my hand. I deeided to share my delight with my father, and induced him to look out and see my pygmies. Like all children, I believed, of eourse, in the infallibility of my father and of my own eyes. My beliefs received something of a shock that day when he told me that my pygmies were just ordinary men, and turned back to his reading. I dare say I eharitably attributed his remark to the rather superficial glance he had given the men; at any rate, I remember believing in the testimony of my eyes in that case, and silently protesting against what was, from my point of view, a most unaccountable lack of interest in a curious race of men. Need I add the explanation of this experience? A little greater elevation, a little less experienee in the interpretation of visual sizes, and man and boy might have had experienees more alike. As it was, those men were inside the range of my father's interpretation of perspective, while they were outside of mine.

Years after I was a party to a similar comparison of adult and child experience; this time, however, I was the adult. We were riding along together, and looking out over the broad pasture land, a little girl of six and I, when we saw some horses grazing quictly a quarter of a mile or so away. There was no difficulty 
in reeognizing the horses as animals of full, ordinary size. And I was surprised into looking a second and even a third time by the little girl's eries of joy at seeing "those eolts," as she insisted on ealling them. Finally, I realized that the horses were to her untrained eyes eolts. I even indueed her to diseuss the matter with me until I told her that they were really horses, and then the look of ineredulous pity for my grown-up ignoranee gave me one of the best insights I have ever had into the truth of the prineiple that ehildren and adults live in different worlds. I also had a elearer understanding of the ehild's mind at that moment from my understanding of the faet that if the quarter of a mile had grown into two miles, I, too, might have been in doubt as to whether the horses were horses or eolts.

If these illustrations have served to arouse in your minds some idea of how the problem of reeognition of size may be made produetive as a speeial study for teachers, we are now in a position to take up in somewhat more systematie fashion eertain problems of teaeler-study, whieh may be briefly indieated in the question, How do teaehers, and indeed all adults, see and reeognize form and size? The reeognition of form is apparently a very simple funetion; and yet as our study progresses I believe we shall find that mental life as it appears in this funetion, is a most eomplex and lighly developed form of aetivity.

Suppose we start with the simplest possible figurea straight line-and see what are some of the eonditions of reeognizing its length. To begin with, let me draw a line on the blaekboard and ask you to draw on paper at your seats a line of equal length. The result will 
invariably be ( $\mathrm{I}$ have tried it time and time again with my classes) that your line on paper will be very mueh shorter than the one on the board, even if you foresce the result and try to aid your faulty reeognition of length by adding somewhat to the line you would naturally draw. The fact is that the lines are so eompletely swallowed up by their surroundings that one ean not see them apart from these surroundings. Estimated in terms of the blaekboard, the line whieh I draw is short; if the same line were on paper it would not have the same relations to the surroundings, and eonsequently it would not seem short. If we start with this natural tendeney to estimate lines in connection with their surroundings and give ourselves a little praetise in the eomparison of different lines, we shall find that we soon beeome expert in estimating blaekboard lines in terms of paper. This does not mean that we merely learn how to eorreet our natural error. We aetually learn to look at the blaekboard lines and the lines on paper in a more highly developed and aeeurate fashion. The best parallels I ean think of are those whieh eome in our ordinary experienees of fashions. You remember those large sleeves that the women used to wear. They looked natural enough onee. The whole standard of our estimation of sleeves was, if you will allow the phrase, on a large, blaekboard seale. Now we have a different seale, and some of our old photographs give us a eurious impression of the absurd largeness of our earlier standard. We have ehanged in our mode of looking at the sizes of sleeves. That ehange has taken plaee so subtly and so gradually that we overlook the ehange. But that ehange has taken plaee, not as a mere superfieial eorreetion of 
our way of looking at things; it is rather a radical and fundamental form of mental growth.

Come back now to our lines on blackboard and paper. Two facts are clear: the first is that ordinary adult experienee is not developed fully in the translation of blackboard lines into lengths on paper; and the second faet is that wc may gradually develop so that direct and accurate translation from blackboard to paper will be possible. And when this devclopment has taken place, our mental life will be really different, just as our estimation of sleeves is different now from what it used to be.

One might find any number of examples of the same general fact that we have illustrated with our blackboard line, by eomparing indoor objects with outdoor objects. Did you ever cut down a very small Christmastree and take it into the house and realize the difference in apparent size? Or have you tried to find a book in which to press autumn leaves, or noticed how small a ehair looks when it stands out on the lawn? The lesson from all these illustrations is the same. We learn to rceognize objcets in their speeial environments, and if we are forced to look at them in new environments, we nced more mental development. Do you wonder that ehildren who have learned a eertain faet in one simple eonneetion need more mental development bcforc they can make wider applieations?

Let us, however, earry our study forward by turning to certain figures which the psyehologists have drawn in their investigations of these matters of visual estimation of size. These figures are so simple that one does not make a very grcat mistake in the estimation of 
their size. But the figures are valuable material for our study, because, though the error is small, the conditions which give rise to the error are fairly simple and easy to eomprehend. In Fig. 1, for example, there are two drawings which are in reality exactly alike in form and in size. The lower one seems, however, to be the larger of the two. The reason for this wrong estimation of size, or illusion as it is ealled, is not diffieult to discover. The two eurved lines that bound either of the drawings are difierent in length and in degree of curvature. When, now, one begins to eompare the sizes of the two enclosed areas

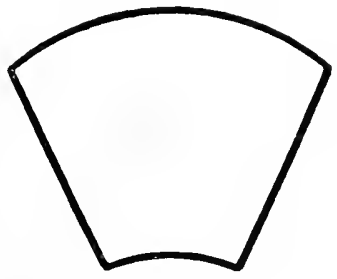
he naturally gives his greatest attention to the neighboring parts of the drawings. This is what we ordinarily do in eomparing areas, and it is usually a sueeessful method. But in this ease the neighboring parts of the drawings furnish unsafe guides. The short eurve, whieh

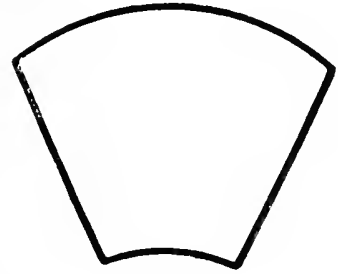

FIa. 1. is the lower boundary of one drawing, gives the impression that the whole area of that drawing is small, while the long sweeping eurve which forms the neighboring boundary of the other drawing, gives the impression of bounding a larger surfaee. It makes no differenee that the images in our eyes from these two surfaees are alike, the estimation goes astray in spite of the real identity of size and form. The interpretation is due to the relation 
in which the drawings stand, rather than to the direct impressions themselves. If one wishes to emphasize this fact of the importance of the relative position of the figures, all one needs to do is to set the two drawings in a new relation, as is done in the second figure, when they will appear to be of the same sizc, as, indeed, they really are.

These figures give us an important lesson, if we will only consider carcfully their teachings. Visual recognition of size is, after all, a complex process. It is not so much the image in the eyc-that is, it is not so much the purely sensory fact which determines the recogni-

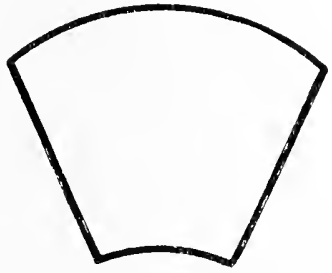

FIG. 2.

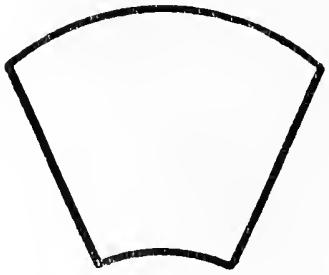

tion; it is much more the factor which we have called interpretation.

I believe that most of us have a crude notion about the way in which we get our knowledge of the sizes of things, a notion hardly more advanced than that of the ancients. Let me give you the account written by the Latin poct Lucretius, of how we come to see shapes and sizes. "I say then," wrote Lueretius, "that pictures of things and thin shapes are emitted from things off their surface . . . as a kind of film, or name it if you like a rind, because such image bears an appearance and form like to the thing, whatever it is, from 
whose body it is shed and wanders forth. This you may learn, however dull of apprehension, from what follows. First of all, sinee among things open to sight many emit bodies, some in a state of loose diffusion, like smoke ... some of a eloser and denser texture, like the gossamer eoats whieh at times eieades doff in summer .... and the vestures which the slippery serpent puts off among the thorns." 1 These thin onter films, Lueretius tells us, fly through the air in all direetions and some of them enter the eye. With an exact eopy of the object in the eye, Lueretius felt that his problem was solved. The mind sees what is in the cye, and the matter is disposed of. Of eourse we have advaneed beyond Lueretius enough to know that there is no outside rind or film taken off the objects which we see; but I venture the opinion that nost of us are quite as satisfied as was Lueretius, if we ean onee explain how the image gets into the eye. The light is foeused in the eye as in a eamera, we say, and here there is an exaet photograph. How many of us have eonsidered earefully the next, and the next step? As a matter of faet, and our illustrations up to this point have amply verified the assertion, the mere reproduction of equal lines and surfaces within the eye, is no guarantee at all that these lines and surfaees will be seen as equal. Seeing is a proeess of mental interpretation. It makes all the differenee in the world what are the surroundings of the objeet. It is always a question of whether the mind has learned to take in its impressions in a fully'developed or only in a partially de-

${ }^{1}$ Quoted from the English translation by H. A. J. Munro. 
veloped way. Seeing is, even in its simplest eases, a matter of interpretation rather than of mere passive impression.

Do you not see the value of this eonelusion for all phases of edueational praetise? When the teaeher onee realizes that seeing is not merely getting images in his eyes, but a matter of interpretation, do you think he will ever be guilty again of believing that ehildren see things beeause these things are held up before their eyes? Our teaeher-study shows us that in order to be seen, things must be held up before our minds as well as before our eyes.

Let us take up some other figures whieh will impress upon us still more deeply the lesson that seeing is a matter of mental interpretation. Fig. 3 represents two equal horizontal lines, with short additional lines forming arrow-heads at their extremities. The arrow-heads are turned in opposite direetions in the two figures, and the effeet is apparent in the underestimation of the upper figure and the overestimation of the lower figure. This figure ean be modified by substituting for the arrow-heads eomplete or partial eireles. One of the most interesting eases of this type of the illusion ean be seeured by asking some one to plaee four eoins in sueh positions that the inner edges of one pair shall be the same distanee apart as the outer edges of the other pair. Fig. 4 represents the way in whieh the eoins should be plaeed to make the distanees really equal. Of eourse, in the actual plaeing of the coins the false estimation will eome out in the fact that the distanees in question will not be made equal.

Further interesting studies ean be made by 
cllanging the figure about in a variety of ways. Suppose we come back to a figure of the same type as those in Fig. 3. Let us take a line and put at one extremity an arrow-head turning inward, and at the other extremity an arrow-head turning outward, as in Fig. 5. In this figure there is added below, a plain horizontal line equal in length to the upper horizontal line which has the arrow-heads. Comparison between the two horizontal lines shows that the upper figure is ap-

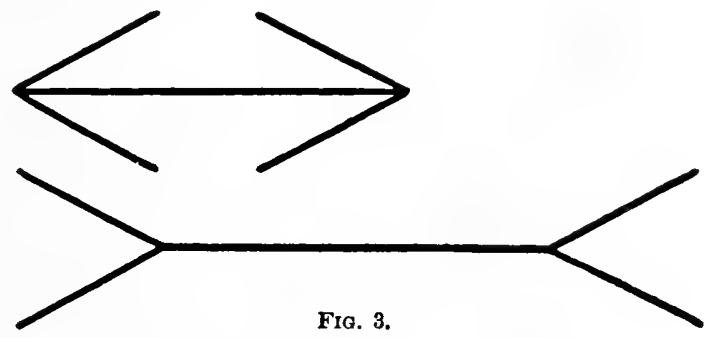

parently neither overestimated nor underestimated. I want to secure your special attention to this figure, for it is one of the best possible examples of what seems to be a simple visual process, and it can be shown to be in reality a most complex figure. As it stands in Fig. 5, it seems to be free from all illusion. But this is due to the fact that there is no adequate means in Fig. 5 of judging it. One would say, in similar manner, of one of the figures in Fig. 3, if he saw it standing alone, that there was nothing unusual about it. In Fig. 3 we become conscious of the illusion through a comparison of two different figures which are in reality equal. To become conscious of the illusion in Fig. 5 we must place about it and within it some points of reference which 
will break it up into equal parts and furnish us with the means of seeing the illusion. This is done in Fig. 6. The short cross-lines, while thes add nothing to the
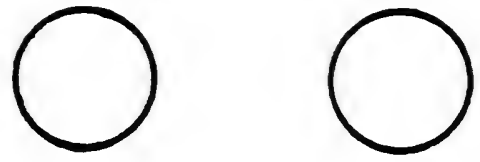

FIG. 4.

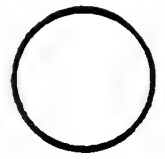

main figure, serte as points of comparison. Thus the cross-line $A$, betreen the arrow-heads, is equally distant from the two ends of the line. The short lines, in and $\%$, at the left and right of the upper figure, are also placed at equal distances from the ends of the line. The same relatire points are indicated lower down in the case of the plain line in the figure. Fow we see that the arrow-heads hare, after all, had a rery marked influence on our risual process. The right side of the upper line, eren though we did not know it in Fig. 5, was stretched out in our recognition of it, and the left side was correspondingly shortened. The space outside of the line was infringed upon on the right side, and the end of the line was drawn back out of the emptr space on the left. In short, the presence of those arrow-heads changed the whole internal and external character of the line. This is just as irue, let me repeat, in Fig. 5 as in Fig. 6. The difference is that in Fig. 6 we hare prorided the means of bringing it into consciousness, 
while in Fig. 5 no such means were present. Thus we see that we can not trust our ordinary obsertation to

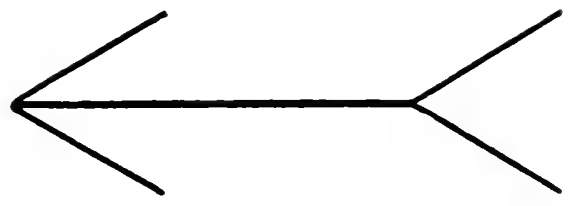

FIG. 5.

discorer all the facts in resard to our processes of recognition. Suppose, for example, that we had stoppe in our study with Fig. 5. The should hare thought of the whole process as rery simple, whereas. as a matter of fact, it is, as shown br Fig. b, rert complex.
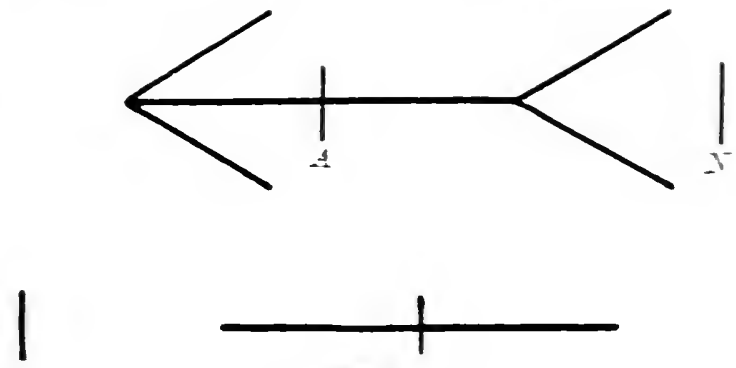

Fig. 6.

Do not try to resist this conclusion to which we hare been coming; by an appeal to ordinar experience. Ino not sar that seeing straight lines seems like a rery simple and eass process. This seeming ease. and acturas risual perception, is like the seeming ease of watking. 
Walking is, however, as we all know, a complex product of development, apparently easy and complete so far as immediate individual experience goes, because of long practise, and because the environment is familiar. One of the best ways to study walking, from the point of view of one's own cxpcrience, is to change the environment, as when one tries to walk a tight rope. Then one understands, perhaps better than ever before, something of the child's difficulty in keeping his balance and controlling his feet. In a similar way one realizes that seeing and interpreting lines is a difficult process when he tries to interpret lines in a new environment. Or an adult may realize something of the child's condition when this same adult puts himself under the directions of a drawing teacher, and finds by comparison of his own ability with that of his teacher that the ordinary person is only partially trained in the recognition of forms and distances.

Mental life is made up of processes which, like the ability to see lines, have reached a certain level, and have then become fixed. In other words, at this level the processes have stopped developing. We fand where we are to-day, forgetful of the past, and ignmrant of the changes which that past has worked out, and consequently blind to the possibilities which lie beyond us. Our study of these simple lines ought to show us something of the nature and possibilities of mental development. The teacher who gets stranded at one stage of development and knows no past or future, is not fit for his profession, for he can not realize what the child has to pass through, and he has no outlook for his own improvement. 


\section{TEACHER-STUDY, ITS SCOPE AND AIMS 21}

The great lessons that eome to us as students of even sueh minor forms of mental development, are tolerance and sympathy for those below us and ambitions for better thing in our own lives. If even a few teachers would take these lessons in regard to spaee pereeption to heart and put themselves through a eourse of training in drawing, and give us aceounts of their experienees, we should have a very valuable chapter added to our teacher-study.

Such a study of our mental development would need to supplement itself with some earefully kept reeords, for there is nothing so easy as to forget what one did and thought at an earlier stage of development. Have you ever worked at a problem slowly and laboriously until the solution was reached, and then wondered how in the world you eould have failed to reeognize what is now so elear? The earlier stage of development in which the problem was not solved, is soon forgotten when you take that forward step which brings you to the solution. It is this forgetfulness of where one started which makes it so hard to show the right degree of sympathy for those who do not eomprehend at their lower level of mental development what one has learned to see so elearly at a higher level. So I say it would be well for us each to go through some series of mental developments and leave behind him some earefully preserved records. This has been done in one ease of space perception with suffieient completeness to furnish us an interesting and helpful example.

The faets I am about to deseribe now will also illustrate to you what the psychologists eall an experiment. We all of us know what an experiment in physics is, or 
an experiment in chemistry, but it sounds a little odd at first to speak of experimenting with one's mental processes. And yet there is a good deal of psychological experimenting which is going on these days, and we are learning more about mental life than we ever knew before, because of the large possibilities of gaining new information which are afforded by these experiments. Our next description will, therefore, have a double significance. It will be a description of a psychological experiment on the development of perception of length, and as such it will give you some insight into the character of the experimental process and into the method of taking records, and it will also throw light on our problem-the nature of our visual perception of form.

Two figures like those with which we became acquainted in Fig. 3, with the arrow-heads turning outward and inward, were drawn on cards in such a way that by slipping an casily adjustable card backward and forward over a fixed card, one of the figures could be lengthened or shortened to suit the wishes of the person on whom the experiment was tried. Fig. 7 will make the arrangement intelligible. On the fixed card, $A$, was drawn a long line with a single arrow-head turning outward. Over this long line was placed the adjustable card, $B$, on which was drawn the short figure with the arrow-heads turned inward. The cards were then placed one on the other, as indicated in the lowest diagram in Fig. 7. At $A$ and $B$ we had the two figures, and by moving the card $B$ backward and forward, the lines could be made to seem equal. The person trying the experiment, or the subject as we call him, adjusted $A$ by moring $B$, until the two figures seemed equal. His 
only task was to make the lines seem equal, not to make them really equal. When this had been done we had,
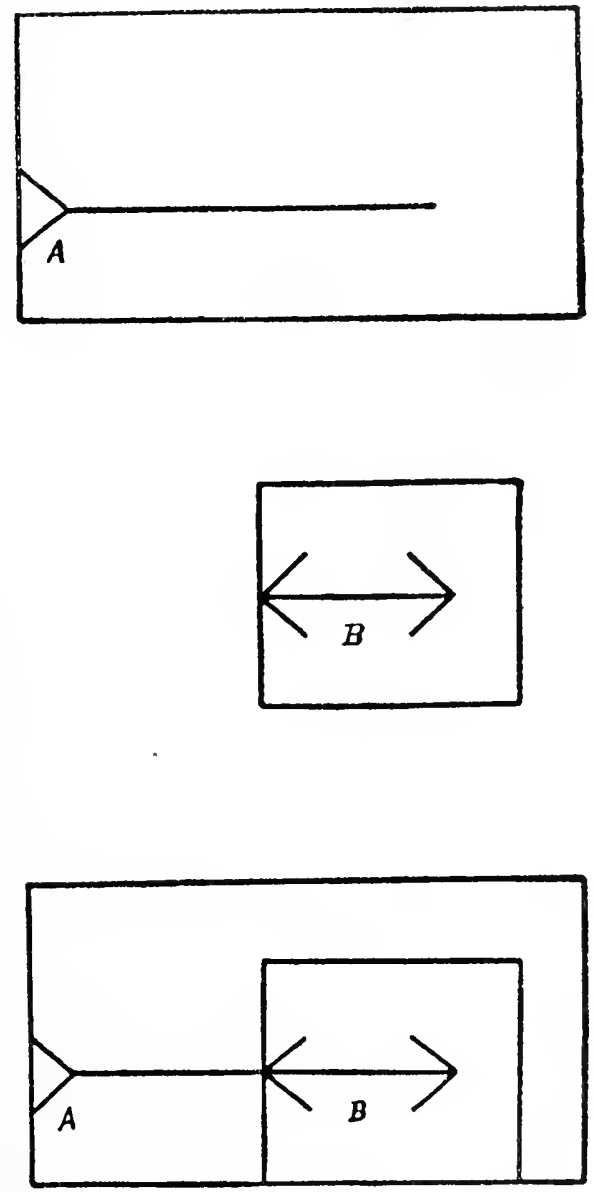

Fra. 7. 
in the difference between the lines $A$ and $B$, a measure of the illusion; for the greater the illusion, the greater was the difference between the length of the lines.

This experiment was tried by the same person hundreds of times, with carefully recorded results, and the results showed that the illusion gradually grew less and less intense as practise went on. Let me give you the results of these experiments in graphic form. Figs. 8 and 9 are made up from the tables of measurements from two different persons.

The meaning of these figures is not difficult to understand, if one remembers that any point in space has both horizontal and vertical position. Take, for example, the point at which the irregular ascending linc in Fig.

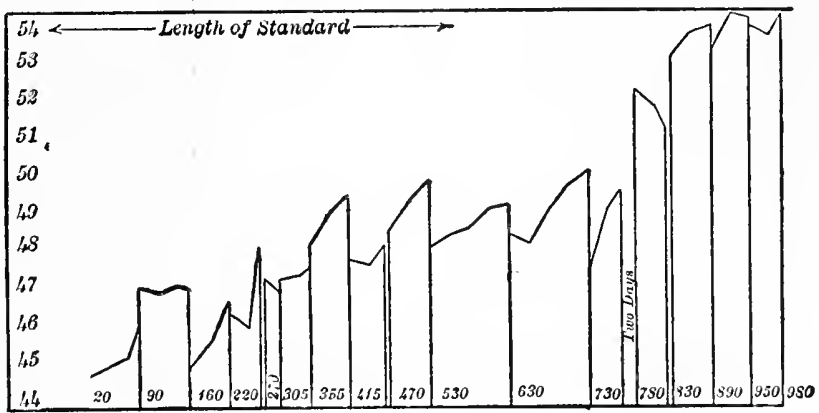

Frg. 8.

8 begins. This point has a certain vertical positionthat is, it is at a certain distance from the base-line of the figure. It has also a horizontal position-that is, it is at a certain distance from the left-hand bounding line. In like manner every other point in the irregular ascending line has both vertical and horizontal 
position. Now, in such figures as 8 and 9 we use these vertical and horizontal distances to express two different kinds of facts. First, if we want to show the amount of the illusion, we place a point at a certain distance above the base-line. In this way distance from the base-line in Figs. 8 and 9 comes to mean degree of illusion. Along the left-hand edge of the figure you will find certain numerals which make this matter of quantity still more definite. Thus, in Fig. 8, 44 at the very base-line means that the length of the line $A$ (Fig. 7 ) in the first experiments was 44 millimeters. The numerals 45 to 54 then indicate various lengths through which the line $A$ (Fig.

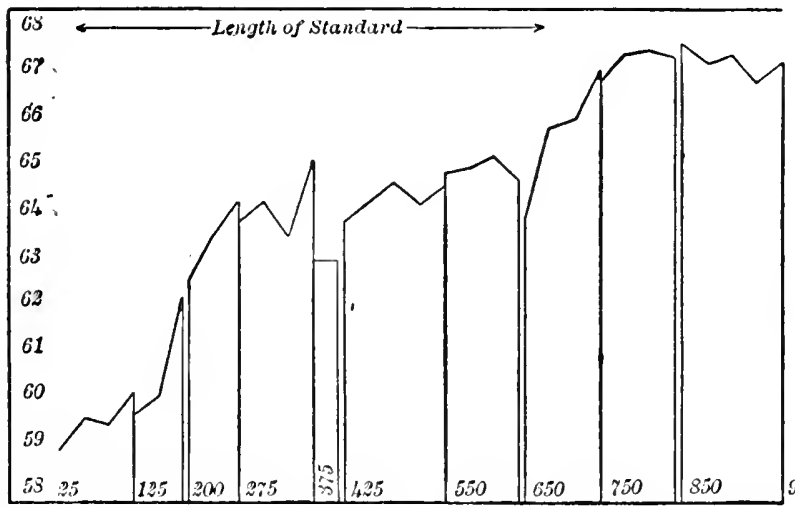
950

Fig. 9.

7) passed until finally it came very nearly to the length 54 , which is the length of the standard line $B$ (Fig. 7). If, now, one takes any point in the regular ascending line of the figure, and refers to this series of numerals at the left, he can see how long the line $A$ (Fig. 7) was at that stage of the experiment. 
At the same time any given point in the ascending line has horizontal position. This horizontal position is used to express the number of experiments that have been tried, and the numbers at the bottom of the figurc indieate how many experiments are represented by each point. Thus the line bcgins in Fig. 8 at 20 and ends at 980 . This means that 980 experiments were tried in all. The fact that wc progress by twenties is aeeounted for by the fact that in most cases in this experiment twenty measurements were averaged before being cntered in the table. The various vertieal lines that interrupt the aseending line tell you how the experiment was arranged as to time. Eaeh single vertical linc means a pause of a few hours in the experiment. A double vertical line means a pause of a night.

I hope that this will make clear the significance of Figs. 8 and 9. Two persons began setting the lines represented in Fig. 7 with very marked errors, and as the trials proceeded, these persons gradually improved until, finally, after 980 trials in onc case, and after 950 trials in the second case, they set the two lines nearly right. Note carefully that this does not mean that the persons in question came to be able to correct thcir wrong way of seeing the lines through some afterthought about the illusion. The fact which is significant in this experiment is that, after a good deal of setting of these lines, one gets such complctc control of the arrow-heads at their extremities that he sees the lines as they should be. He undergoes the same kind of change in the way of looking at these lines as that which all of us have undergone in our way of looking at big sleeves. The interpretation has changed. Menta] 
life has developed in a small way, and the arrow-heads which were before eonfusing additions to the horizontal lines, have now been mastered. The arrow-heads are accordingly no longer sources of an illusion; they are regularly interpreted factors.

I wish cvery teacher could be induced to try this or some similar experiment, so that he or she might learn in his or her own experience what changes in mental life a little training can bring about. The meaning of the statement that children see things in a way that is different from ours would become a living fact, rather than a bare statement. This experiment shows in the brief space of a few days what in ordinary life, where no attention is given to this illusion, would never take place at all. It is therefore an interesting case of development beyond ordinary experience. Furthermore, the fact that a rccord was kept makes it possible for us to give a very exact account of the way in which the development took place.

Something of the same kind can be seen when one goes back, after a long abscuce, to the home of his childhood, and notes the smallness of the house and yard and the small clcration of the neighboring hills and the nearness of the next house. To onc's childish mind distances were much vaster than they are now in adult life. One has undergone in all these years a slow transformation in his mode of secing things. The whole interpretation of objects is on a different scalc. This is clearly a case of mental development, though it is development in a relativcly simple function, the function of seeing sizes. Remember that if such a simple mode of interpretation is capable of such marked transforma- 
tions through accumulation of cxperience, then the more complcx modes of interpretation must be capable of much grcatcr development through similar processes of expcrience.

Let us come back, after this description of actual observations and rccords of the transformations which can be produced through practise, to a more complete
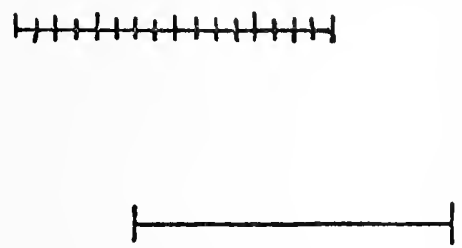

Fia. 10.

illustration of the fact with which we beganthe fact that there are a grcat many illusions into which our undeveloped adult consciousness falls. If you draw two lines of equal length and then break up one of the two with a scries of short cross-lines, as in Fig. 10, the two lines will no longer look equal, but the interrupted line will secm longer. The same principle holds for squares which have been broken up by cross-lines, as shown in Fig. 11. This whole group of illnsions is described by the general name, illusions of filled space. The namc means, of
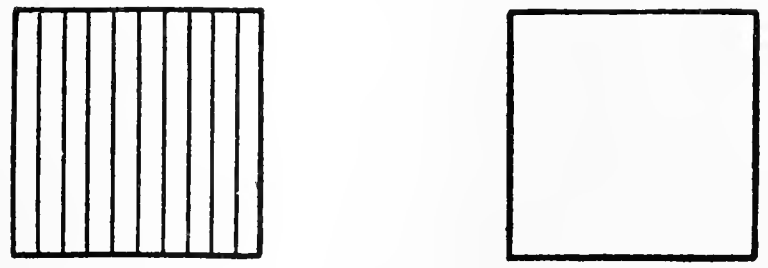

FIG. 11.

course, not that one line or one square is absolutcly cmpty space and the other filled, but that in one case 
the filling is of sueh a speeial, noticeable eharaeter that it is, as eompared with the other, uniform line, or square, much more filled. The illusion is easy to understand. There is more to pay attention to in the filled figure. This moreness we easily turn into moreness of length, while as a matter of faet it is merely moreness of filling. Again it is interpretation that is aecountable for the illusion.

An interesting faet in this eonneetion is that with large objeets our interpretation is governed by other motives. In the ease of an empty room, for example, the barren laek of furnishings ealls our attention to the size, and the empty room looks unusually large, not small like the empty square. Or again, when the stripes whieh in our figure of the square make the figure look wide, are transferred to a garment, the effeet is to earry vision up and down the lines and to eall speeial attention to the length instead of to the width, and thus we eome to understand the various forms of subtle art by which the rotund matronly figure is elongated to our guileless and undeveloped eyes.

Again we may refer to a group of striking figures in whieh the false estimation of distanees results in a distortion of direetions. The earliest figure of this sort to be noted and deseribed was found on a tapestry pattern. It is reprodueed in Fig. 12. The long vertieal lines are parallel, but they seem to eonverge and diverge, thus giving the whole figure an irregular eharaeter, whieh destroys entirely the parallel appearanee. The explanation of this figure does not seem to be simple. The short eross-lines are evidently the faetors whieh eomplieate interpretation; but the exact way in whieh the 
eross-lines produce their effeet is diffieult to determine. There is a simpler figure of elosely related type to which this eomplex pattern is generally redueed for purposes

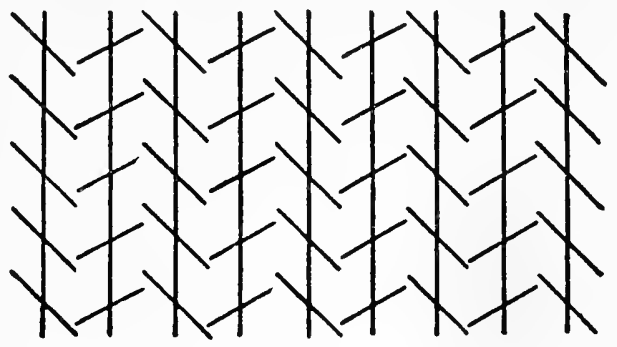

F1a. 12.

of explanation. The simpler figure is presented in Fig. 13. Here the long oblique line is the center of intcrest. It is interrupted by the space between the two verticals. The result is that one can not see the oblique

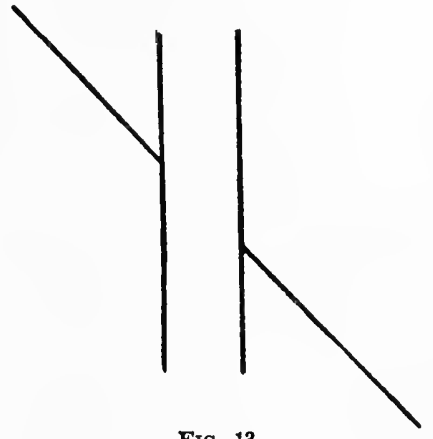

Fia. 13.

line as a single continuous line. The left-hand part seems somcwhat too high, whilc the right-hand part is too low. If now one thinks of the oblique lines as increased in number, as in Fig. 12, thcy beeome the stronger factors, and they sueeed in tipping the interrupting lines, and do not themselves suffer deflection as in the simpler figure.

Another interesting group of illusions appears in eertain arehiteetural forms. A high eolumn, for ex- 
ample, the sides of which aseend in perfectly straight lines, seems to be too slender at its middle point. In other words, sueh aseending boundaries of a column naturally appear slightly eoncave at the middle. It has often been noted that the Greek eolumns were so eonstrueted as to eounteraet this illusion by having a marked eonvexity of their aseending lines-that is, the Greek columns were really slightly bulging at the middle, so that they might produee the pleasing impression of straightness rather than eoneavity.

Enough, however, has been said to make clear the fact whieh we started out to emphasize in this first discussion. The teacher's own mental life is a world in whieh marked variations and undeveloped possibilities are always showing themselves, if we will only look for them It is not merely in the more eomplex proeesses of reasoning and lofty thought that this holds true. It is true that even in the simplest process of recognition of very commonplaee figures, we have mueh that might be improved by training and development.

It remains, in closing this first discussion, for us to ask, why do we not ordinarily develop further in our recognition of forms. The answer is not far to seek. Ordinarily practieal life does not demand it, and we simply live on with half-developed faeulties, because these are good enough to meet our immediate needs. We are like men of every age, for in every age there have been intellectual prizes which have awaited the finding; but men have lived on and on, satisfied with good enough, until some vigorous, self-possessed mind has appeared and has boldly sought to improve beyond the immediate praetical demands of the lower life. Sueh a mind always 
finds effort repaid by further improvement, until finally he eomes to live at a new level, with broader outlook in every direction. If we would rcalize the true meaning of the word edueation, we must think of it not merely as a word to apply to others; we must think of the possibilities of self-improvement. Teachers often get so absorbed in doling out, over and over again to their children, the same little fund of facts, the same little incentives to new experience, that they eome to think of themselves as finished products. The practieal lesson of self-knowledge, which will grow elearer to you from any intelligent study of your own faeulties, is that you can sympathetically help others to grow only while you are growing yourself.

If you have observed all there is to be seen in a plant or animal, I mean if you think you have observed all there is, then throw it away, it is useless for a lesson in nature-study. The true view, the vicw you must get if you would be a helpful teacher, is that you have still before you large unexhausted possibilities. You may be a little in advanee of the children, indeed you ought to be; but if you are so far in advanee of them that you have no bonds of sympathy in undeveloped faeulties which you reeognize, then you can not understand them and they will not understand you.

And now to make these general statements more speeific, and to give the illustrations of spaeial form whieh we have been studying in our reeent diseussions some direct praetieal bearing, let it be noted that our recognitions of form and size are in general very mueh in need of special training.

The subjeet of form-study, which is gradually com- 
ing to have a recognized place in our elementary schools, is one of the most timely additions to our course of study. The reason that the value of form-study is not more fully realized by teachers is that teachers are very gencrally without knowledge of how exceedingly defective is their own mastery of form. We look at all sorts of objects in adult life in the most superficial way. We have literally cultivated the habit of neglecting form by our failure to develop this phase of our mental lives. The result is obvious in a thousand ways. We miss not only the esthetical pleasures that we might gain, but we miss also the great funds of information which might be had from the mere looking at objects, if we would only look with the mind's eye and not with a vacant and uninterested gazc. I should say to teachers, learn to look at everything that presents itself, and note its form and size and position. If the object has no other value, there is at least value in the training of one of your faculties. Furthermore, such careful observation may bring out values which you know not of. The basis of higher mental life must be laid bcfore that higher life is possible. The trouble with most of us is that we try to carry on the training of our faculties from the wrong end. We get books on art and architecture, instead of going out and getting our eyes open to the facts that would put content into our reading. Let us change all this. We are beginning to do it for the children in the schools, in that we are beginning to train them in the rudiments of seeing. This reform in the schools would stride forward with great rapidity if we could only realize our own needs as tcachers. Let us begin this training of ourselves. 
One of the best ways that I know of to train oneself in observing, is to begin drawing. Draw some one thing every day. It need not take very mueh time. Go home and draw something to-day. Do it in the privaey of your own room if you are ashamed of the results. Do not tear it up when it is done, but go out after you have drawn and look at the objeet again. You will look with keener interest and insight and you will do better next time. Do not do this for the sake of trying to beeome an artist, and do not drop your practise after the third or fourth day. Remember this is a normal sehool in whieh the teaeher is pupil as well as faeulty. You will be repaid in time more than you imagine. You will not need to worry about examinations in your normal sehool; you will not need to be afraid of ehanges in the eourse of study. And I venture the propheey that you will not be exhausted by this work. It is not the kind of work that teaehers who are overworked, as they eall it, eomplain about. They eomplain about work that does no eontribute to their mental growth and is not done in pursuit of this kind of self-improvement.

But I will not exhaust your patienee with exhortation. If the moral of our introduetory diseussion is not clear now, it never will be. Let us review briefly as we elose. Teacher-study will help us to understand ourselves and will indireetly help us to understand the ehildren. If we take some of the simplest aets of seeing lines and figures, we shall find that we have yet large possibilities of development, and we shall find that development means a ehange of a very fundamental type in our modes of mental reeognition. These possibilities of development, as well as the figures by which the pos- 
sibilities were revealed, all go to show that recognition of size is a fact of interpretation, not a mere fact of impression. And finally, the practical pedagogical lesson is that interpretation of size and form may, and should be more highly cultivated by all of us. 


\section{CHAPTER II}

HOW EXPERIENCES ARE CONSOLIDATED INTO INTERPRETATIONS OF MEANING

DiD you ever ask yourself why it is that we have two eyes and two ears? We all recognize the fact that we need two legs in order to make walking possible; that we frequently need two hands-one to hold the object on which we are working, and the other to do the manipulating. But I venture to say that most people are not aware that seeing is never perfect unless both eyes are cooperating, and that hearing is never complete unless both ears are in use. The truth is that natural and complete visual and auditory experiences are just as much dependent on our two organs of sight and hearing as natural walking is dependent on the combined action of two legs. And the unfortunate individual who is deprived of one eye or one ear, has to make use of unusual and clumsy means of sight and hearing, just as the man deprived of one of his legs has to make use of clumsy devices for walking.

Let us demonstrate this in a simple experiment with hearing. The experiment is one which can be performed very easily by any one. Ask the person on whom the experiment is tried, or the observer as we may call him, to close his eyes, and then let the experi- 
menter make some sort of a snapping sound (snapping the fingers or snapping with a card will produce suitable sounds) just in front of the middle of the observer's face or just behind the middle of the back of his head. You will find that the observer will make the greatest mistakes in trying to tell where the sound came from. Sometimes when it is in front of him he will tell you it is behind, and vice versa. In other words, for sounds which are thus half-way between the two ears, there is no means of distinguishing easily the difference between what is in front and what behind. Now let the experimenter move his hand in making the snapping sound slightly to the right or left of the middle line, and it will be found that the observer can give much more accurate localizations-that is, the moment the sound is stronger in one ear than it is in the other, the observer has a complex experience which makes it possible for him to make a comparison and to understand his impressions. The two ears cooperate in these latter cases, in that one reports the sound with a greater intensity than does the other, and by this means the observer recognizes that the sound is on the side of the greater intensity.

We make use of the same principle in ordinary life. When one wishes to locate a sound, he moves his head around in this direction and in that until finally he gets a different impression in the two ears, and then he can locate the source of the sound on the side of the stronger impression. It is probably true that the difference in the way in which the sound gets into the two ears is also of importance, but our discussion need not go into further detail. You see that, after all, there is some 
necessity in ordinary hearing for the use of both ears, at least, if we are to know accurately where the source of the sound is located.

Similar facts can be demonstrated for the eyes. Most of us believe that the world looks the same when viewed with one eye closed as it does when viewed with both eyes open. A simple experiment will convince you that one-eyed vision is less complete than two-eyed vision. Close one eye. Hold up some small object directly in front of the open eye-a pencil or one of your fingers will do; or it will be better yet if you will let some one else hold something in front of you. Now raise your right land above your head so that it is out of the range of vision, and rapidly bring it straight down, trying to place the end of your index-finger on the end of the object. After you have brought the finger down and failed to touch the object, open the closed eye and see how clearly the mistaken positions of finger and object are seen with two eyes. One who has tried this experiment a number of times will never be in any doubt as to the fundamental value of two eyes. With two eyes we see the position of objects in depth clearly and vividly; with one eye a great part of this recognition of depth is lost. If you once get into the habit of observing this difference, you can notice it in a great variety of cases. Close one eye and look at a distant group of trees, at a house, or at some object in the room, as a chair, and notice how flat they all look. The best instant at which to notice this flatness is just at the moment when you open the closed eye and see the object fairly, leap into depth.

This difference between one-eyed vision and two- 
cyed vision is due to the fact that the two eyes get different views of any object at which they look. With the right eye you see a little farther around the right side of the object, and with the left eye you see farther around the left side of the object. The result is that the image in one eye is different from the image in the other eye. Our idea of depth depends on this difference. This is very neatly illustrated in the common instrument with which you are doubtless acquainted, namely, the stereoscope. You will recall that there are always two pictures to look at. These two pictures are mounted in such a way that one is seen with the right eye, the other with the left. You may not have noticed it, but the two pictures, the one on the right and the one on the left, arc different. They were made in cameras that have two separate openings corresponding to the two eyes. One picture shows a little more of the left side of objects, while the other shows a little more of the right side. If it were not for this difference and for the fact that this difference is now preserved for your vision, in that you look at the two pictures through the stereoscope so as to introduce one picture into one eye, and the other picture into the other eye-I say if it were not for this difference in the two photographs, you could not see the solidity which is the charm of stereoscopic pictures.

The question which arises at once after one has been shown by these experiments the importance of two-eyed vision is, Why is it, that when we close one eye, things are not ordinarily recognized as unusually flat? The answer to this question is to be fourid in the statement that in ordinary one-eyed vision which is 
not subjected to close examination, we get the meaning of what we sec by the aid of past experience. We do not see things fiattened out as they really are presented to the single cye, but we see beyond the flatness and understand what the objects would be if we saw them with both eyes. In other words, we have become so accustomed to our full two-eyed form of interpretation, that, even though only half the usual amount of visual experience is present, we turn it into the usual mold of complete interpretation. In doing this we are aided by the familiarity of the objects and by our knowledge of their surroundings. If we prepare groups of relatively strange objects in a wholly unknown order, as we can easily do by passing threads backward and forward at different levels in a box, then one-eyed recognition of depth becomes almost or quite impossible.

"But," some one will probably ask, "how is it that we never recognize in ordinary life what impressions are coming in at the one eye or the other, and at the one ear or the other? If it is true that the two organs of sense in each case are of such importance, why do we need to make this careful study to find it out?" If you will get the true answer to these questions, you will have one of the important facts in regard to your own mental lives. The fact is that we do not pay attention to sense impressions for the sake of getting the impressions themselves; we pay attention to sense impressions for the sake of understanding their meanings. Now, the differences in auditory intensity which come to us through the two ears, are of no interest as mere facts of intensity, but they are rich with meaning; and that meaning is what we have learned to recognize. Inten- 
sities mean, in such cases, position in space. In the same way the different views of objects which we get in the two eyes, are of no interest as different views, but they are of great interest in their meaning, for the meaning of these differences is solidity and depth. The solidity and depth is what we see, for at our advanced stage of mental development we attend to the meaning only, and neglect entirely the simple fact of sensory differences from which we derive the meaning.

Mental life is made up in very large measure of these processes of getting behind experiences and grasping meanings. Take, for example, our recognition of a word. A word taken as a mere sound is a very meager experience. Take such a sound as " cold." Pay attention to it as a sound. It is hard and guttural. There is nothing attractive about it; taken all in all, as a mere sound, it promises little for any one's thinking. Imagine yourself a foreigner, unacquainted with all the fulness of meaning that we put into the world becausc we understand it, and you will recognize what we are trying to emphasize when we say that our mental states are not bound down to present impressions, but are constantly reaching out, and are attaching to the impressions a rich fund of interpretation.

Or take another illustration. What is a coin to the intelligent adult? Is it a bit of metal with certain decorations? As a matter of ordinary experience, you know how little attention we usually pay to the decorations. It is a commonplace form of amusement to try to see how little most people know about what is on coins. Greenbacks are overlooked in the matter of appearance, even more than coins. Our memory of the 
size of a common greenback is very defective. But when it comes to meaning, we all have a clear realization of the meaning of currency. We know that there is a ccrtain additional fact behind the mere appearance of the coin or the greenback, which additional fact we call value. Value is the power to bring us desirable things through exchange. This understanding of value is not present in the child's mind, for the child has had no experience on which to base recognition of meanings. He is engrossed in the bright hard metal. Not so with us. We receive the impression, to be sure, but we do not linger even for a moment on the impression. Our attention is upon the remoter significance. Just as we sec solidity in ordinary one-eyed vision, which is in reality flat and meager in content, so here in the bit of silver, we realize the possibilities of new cxpericnces not revealed at the moment.

Mental life is full of illustrations of this type. Indeed, so constantly do we attend to meanings instead of to the real mental states that it is for the most part impossible for us to separate the two. When we look away across the landscape, for example, and see the distant green fields, we are having an experience in which the present impression and its meaning are very closely woven together. As a matter of immediate vision, the color which the eye receives from those distant so-called green fields, is a very dark bluish green-indeed, in some cases it may even be distinctly blue; but we do not ordinarily notice that. We have come, through past experience, to know that colors grow darker and milder in tone, as their sources are more and more removed from us, and so we think of the distant blue-green, not 
as it looks, but as it means. There where the grass is growing it is bright green, and the patch of color in our landscape, which is not bright green, means that grass, and we understand it. We see in our mind's eye the meaning, rather than the present shade of the color. One can convince himself that he has gone far beyond present experience in such a case by pulling up a handful of grass and holding it in the line of vision, and thus helping himself by contrasting the two experiences of color to discover what is the real color of the rcmote field. Or by an examination of some landscape painting, you may convince yourself that the artists have known this fact about colors for a long time. If they wish to bring up in your mind a distant object of any kind, they tone down its colors and darken the shade, and you see it, not as mere color, but as alive with meaning.

Perhaps some of the best illustrations with which to make clear this fact that we fill out all our lives with meanings, are the illustrations in which we find men attaching the wrong meaning to experiences. One walks out on a dark night and sces the fleeting, shifting darks and shades. What infinite possibility of ghostly interpretation if one is only disposed to read meanings into what he sees! Indeed, I think much of the mystery which men have been wont to read into their environments may well be dwelt upon as showing how much of harm as well as of good may be accomplished by this habit of ours of looking for the meanings beyond our impressions.

The ancient priests knew well how to furnish to the minds of the ignorant people the impressions out of which they could derelop the weirdest meanings. 
Suppose you did not know anything about the modern stereopticon, with its projection of pictures and scenes in more than life size. Suppose that on some night, or in the shrouding darkness of a temple, you should be confronted with the outlines of a face projected by such a stereopticon. What would you see? You would see with your eye nothing but a flat image. But your active mind would not stop there. You would enlarge upon that image in the only terms that could possibly suggest themselves to your mind, ignorant as we have assumed it to be of the projecting stereopticon. You would literally see a real thing. If you will follow out that line of reasoning, you can understand much of the deccption practised by the ancient priests. They kncw how to project images, not as we do with the stereopticon through a glass lens, but by means of metallic mirrors, especially by means of concave mirrors, which are fair substitutes for the lenses which we use. For a screen, these priests used the smoke rising from sacrifices, or they used the temple walls. These served very well in place of our sheets of canvas. The people, ignorant of all the machinery back of the image, saw the projections as visiting deities, and the trick is explained.

It is interesting to read some of the accounts. Thus, in the following we can fairly see the priests getting their image into focus beforc the gaping multitude. It is an account given by Damascius. He writes: "In a manifestation that ought not to be revealed, there appeared on the wall of a temple a mass of light, which at first secmed remote; it transformed itself in coming nearer into a face, cridently divine, of a severe aspect, but mixed with gentleness and extremely beautiful." 
An account by the Italian, Cellini, of one of his experiences is amusing in its transparent simplicity. Cellini relates that he became acquainted with a Sicilian priest, skilled in necromancy, and asked the priest to impart some of his knowledge. The priest said that the man must be of a resolute and steady temper who enters upon the study of the black arts. Cellini goes on to say: "I replied that I had fortitude and resolution enough if I could but find an opportunity. The priest answered, 'If you think you have the heart to venture, I will give you all the satisfaction you can desire.' Thus we agreed. The priest, one evening, prepared to satisfy me, and desired me to look out for two companions. Having secured two of my intimate acquaintances, we resorted at night to the Colosseum, and there the priest began to draw circles on the ground with the most impressive ceremonies imaginable. He brought with him several precious perfumes and fire, with some compositions also which diffused noisome odors. As soon as he was in readiness, he made an opening in one of the circles, and, taking us by the hand, led us in, at the same time ordering his partner to throw perfumes into the fire. The ceremonies lasted about an hour and a half. There appeared several legions of devils, insomuch that the amphitheater was quite filled with them. The priest requested me to stand resolutely by him, because the legions were now about a thousand more in number than he had designed, and besides were most dangerous. $\mathrm{My}$ companions were in a terrible fright, and even the priest trembled with fear, endeavoring by mild and gentle methods to dismiss the spirits in the best way he could. The priest entreated us to 
have good heart and take carc to burn the proper perfumes. Though I was as much terrified as any of them, I did my utmost to conceal the terror I felt." Does it need any comment to make it clear that the smoking incense was nccessary to serve as a screen for the dancing spirits, that the circles on the ground were necessary to keep the visitors in proper range, and that the attending terror of the whole occasion augmented powerfully the natural tendency to see a real being in each shadowy phantom?

Do not fail to keep in mind the general fact which all of thesc examples are intended to illustrate. The gencral fact is that the character of any mental process depends, not merely upon the immediatcly present factors, but also, and very largely, upon what one sees beyond the given factors as the rcmoter meaning. This fact that we add meaning to all of our experiences is one of special importance to our teacher-study. It is very easy to overlook it from the point of view of ordinary experience. The common man wishes to gain complete knowledge of any object. This he desires without particular reference to the question of what is presented and what is seen as meaning. Now and then, in certain exceptional cases, even the ordinary man becomes interested in the difference between presented fact and interpretation. This is the case when he has to sit on a jury and compare the testimony of two or more witnesses for the purpose of discovering exactly what it was that presented itself to the eyes of each observer, and what each added in the way of perfectly honest private interpretation of meaning. In such a case the ordinary man is, like 
ourselves, interested in the qucstion of meaning versus impression.

The teaeher's interest is not quite the same as that of the juror, but is very closely related to it. The teaeher wants to know what parts of a given experienee which he and the child are having at a given stage in any study, are really common to both. If he eould sharply distinguish in his own experience that which is added meaning from that which is immediately presented impression, he would bc better able to understand that he and the ehild may be looking at the same object, and yet be having vastly different experienees.

The illustration that comes first to mind is, of course, the illustration of the new word. I remember the first time I heard the words Ornithorhynchus paradoxus. They were spoken by a teacher who knew what they meant, and his whole thought was doubtless off in Australia, where there is an interesting animal bearing that name. What was my state of mind? The name had a sort of impressive sound for me, which I dare say my teaeher was not notieing at all. I thought that name over as a kind of mouth-filling combination of rather melodious noises and nothing more. My teaeher and I were in the presenee of the same experienee, so far as the immediately given factors were concerned, but he had the meaning, and I had only the sound.

It is not merely words, however, as common as they are in our school life, whieh illustrate the absence of meaning on the one side and its presenee on the other. Did you ever go with some intelligent teaeher of anatomy to examine his museum? Did you ever notice how every ugly bone and jar grows eloquent with inter- 
est when he begins to let you into the secrets of what he sees in those specimens? And did you ever note by contrast how barren and commonplace a museum is when you are left to wander about by yourself, with your ideas tied down to the little that can be seen in the merely present fact?

The ability to add meanings to impressions is always a mark of extended experience. The teacher differs from the pupil in the larger degree of ability to sec meaning in the objects about him. The expert has a greater range of interpretation than has the novice. Everywhere, richer meanings grow up with fuller experiences. One may almost define what we have been calling the meaning of impressions by saying that these meanings are past experiences brought over into the present. Thus, when one sees a dark blue on the distant horizon and knows that it means a green field, this recognition of meaning is due to the fact that on some previous occasion a dark color has grown brighter and lighter as one has walked toward it. In other words, the present impression has meaning because in some past time we discovered the meaning of a similar impression. The richness of present interpretations will, accordingly, depend on the degree in which one has profited by past experiences, and there is a very large justification for the statement that education consists in the process of adding meanings to given impressions.

Such a definition of education as that which has been offered, requires some further explanation before it can be accepted as cntirely safe. Not all mcanings are desirable additions to present impressions. Thus, when the savage learns that an eclipse means the wrath 
of some avenging dicty, he has doubtless, in one sense of the word, had an enlargement of expericnce, but he has hardly been improved, or cven educated, in the best sense of the word. What he needs for his education is not merely the addition of meaning to his impression, but the addition of a correct and productive meaning. And just here is the indefinitely large problem: What meanings are correct and productive as additions to given impressions? Here is the serious side of the teacher's task. Be sure, as you face your pupils with a new impression, that they will soon attach some meaning to it. Your problem is to find out what the impression is, and what is the appropriate meaning. Your next problem is to discover what conditions arc most favorable to the establishment of proper meanings, instead of false meanings, in the minds of thesc pupils. And, finally, your constant task must be to discover what meanings are growing fixcd in your pupils' thoughts, and to guard most jealously these growing processcs, and by constant supervision to see to it that only productive meanings grow undisturbed.

Since this matter of the mcanings which are attached to impressions is of such importance for our scientific study of the teacher and the teacher's work, it is worth while for us to dwell upon the naturc of these added meanings at some length. And the lesson which one must learn at the very outsct of this study and must keep in mind all along, is the lesson which has already been taught by our examples, but can never be too fully emphasized, namely, the lesson that it is one of the most difficult tasks in the world to know in any given casc what is meaning and what is impression. 
There are certain cases in which impression and added factors are sufficiently separate so that any one can easily discern both of them. 'Thus, we have all had the experience of meeting some person whom we have met once or twicc before and whom we have nearly forgotten. We have to search in the remote corners of our minds for some stray fact which will guide us in what to say and how to treat the person. Perhaps the earlier experience was agrecable, and with a faint recollection of that in mind, we try now to renew the pleasant relations. We are all the time very conscious of the fact that past expericnces are being revived to aid us in understanding and dealing with the present. In other words, we are conscious of the fact that the interpreting meanings which should comc out of the past and illuminatc the present, are separate from the immediate impression. We recognize in our effort to remember, that the process of finding some of the remoter meanings of the face and voice are different from the immediatc impressions.

Turn from this stranger to your familiar friend. To be sure, the present impression is again nothing but a facc and a voice; but these are now no meaningless visual and auditory impressions. The face and the voice arc full of rich significance. You know just how to act, and you have that comfortable feeling of familiarity that comes from a clear and full knowledge of the meaning of your impression. The meaning comes so easily in this case that we do not think of it as separate from the impression. We do not say that we remember our intimate friends-we say that we recognize them, thereby indicating that in this case meaning and im- 
pressions arise together. To be sure, the meaning never could have appeared if it had not grown up in past experience, but at this stage of development it is not referred back to the past at all. It is not a memory, it is a present fact. Let us call it a present meaning, in order to distinguish it from something remembered and dragged into the present out of the past. Present meaning and memory are, then, two different forms in which experience gets itself added to present impressions. Memory is the more obvious case of enlarging upon our impressions; present meaning is the more common and the more important case.

Let me impress upon you the difference between present meaning and memory by means of an illustration which was furnished to me by a friend. He feels a very strong dislike for horses. He can not bear to come near a horse's head. This is, as you readily see, a way of looking at the horse which differs radically from the way in which most of us look at that animal. My friend's interpretation is that the animal is harmful, to be avoided, and thoroughly disagreeable. For a long time he said this peculiar personal attribute toward horses remained a mystery to him. No memory served to show him how he had acquired this sort of a present meaning. He knew he differed from most people whom he saw liking and admiring horses, but that was not enough to dissuade him from his view; for him horses were and are thoroughly distasteful factors of experience. He confided his feelings to an uncle one day, and received from the uncle the information which cleared up the whole matter. When he was a boy he had been bitten by a horse. That experience had left its mark 
on his future interpretations of horse nature, not in the form of memory, for the incident was entirely forgotten, but in the form of a thoroughly established meaning. To-day he looks at horses as that experience led him to know horses; but all he has carried away for his mental life is the meaning of the event, not the actual memory image.

Each of us has had similar experiences, though perhaps less clearly defined. Have you never taken a strong dislike to some one you have just met? Have you not read into his face or manner all sorts of disagreeable traits? And then have you not suddenly realized, as an explanation of the whole interpretation in which you have been indulging, that this man looks like-some one you knew in the past? In other words, you have becn disliking him because your experience has been such that these special features which he exhibits, mean something unpleasant to you. Notice that in such a case your recognition of present meaning could not depend on memory, for the memory came after the interpretation. The meaning is explained by your recalling after a time some special face in your past experience which has hclped to establish the meaning, but the interpretation was something different from the explanation afforded by memory. The interpretation is immediate and definite; memory follows in such a case far behind. If there are cases in which tardy memory arrives to explain our sudden interpretations, how many cases are thcre, do you suppose, in which the interpretation goes forward in the same way but is not explained at all? I think a careful analysis of experience would go to show that our lives are made up of interpretations that 
are so settled and fixed that the memory factors which would explain them are long since dispensed with.

Indeed, there are some cases in which memory can not be invoked at all in the explanation of our present meanings, and yet these meanings are the results of past experience. Take the illustrations with which we opened this discussion, the illustrations of ordinary hearing and seeing, and the demonstration of the utility of two ears and two eyes. When one hears a sound in the two ears and receives in so doing, impressions of such a character that the sensation on one side is stronger than the sensation on the other side, he interprets the location of the source of the sound on the basis of the difference in intensity of the sensations in the two ears. This may be stated in other words as an interpretation of the meaning of the experiences brought to him by the two ears. If you will watch an infant you will see that the infant does not interpret the meanings of sounds in any such successful fashion. Indeed, one need not go as far back as infancy. An experimenter ${ }^{1}$ has recently demonstrated that adults may, through experience, improve very noticeably in their ability to locate sounds. This shows that adults may become more expert in the interpretation of the meanings of their impressions. What is this process of growing expert in interpretation? Certainly it is not cultivating memory. We do not say to ourselves, this sound in the right ear means the same kind of sounding body as that which we experienced yesterday. Indeed, as we have already pointed out, we do

${ }^{1}$ Professor Pierce, in Studies in Space Perception, p. 98 et seq. 
not even distinguish the two sounds in the two ears as scparate. Experience has grown up in these cases by a kind of blind process of trial. The infant or the developing adult does not so much think about meanings, as he tries to fit himself in a practical way to the impressions. Sometimes he fails to fit himsclf to the impression, and suffers the consequences; sometimes he succeeds, and enjoys the advantages. Thus he accumulates certain habits of turning in the right direction, not because he knows why, but because his best and most satisfactory experiences are those which resulted in movement in a certain direction in response to a certain combination of impressions. It is this method of blind accumulation of habits of interpretation which gives us, for example, the present meaning of water when we are swimming, or of a turn in the path when we are riding a bicycle. No memory is necded, for the meaning in this case is recognized as a demand for a form of immediate activity and has grown up by personal effort.

Or take again the illustration of seeing with two eyes. When we see a little more of the right side of an object with the right eye, and a little more of the left side of an object with the left eye, we are not surprised. We do not have to refer back to past experience for some explanation. We have had such expcriences thousands and thousands of times every day, and the result is we have a ready-made form of interpretation. We know what that means. It means a solid object. So fixed is this mode of interpretation, that if we persuade ourselves to look into a stereoscope, we must interpret those pictures in terms similar to our ordinary experi- 
ence. We see in the stereoseope a single solid image, not what is really there, namely, two flat pictures.

Our minds are thus eonstantly seeing in present impressions their meanings. These meanings are the results of past experiences, but they do not depend in any great number of cases on any clearly recognized reference to remembered experiences. You look into a mirror, for example, and you are performing an act of double interpretation. In the first plaee, you see the object straight ahead of you, baek of the mirror. This experience is due to a fixed mode of interpreting experiences whieh if formulated would lead to a statement of the general principle: light has traveled in straight lines in a suffieiently large number of past experiences so that one is safe in interpreting present cases in the belief that it is always true that light travels in this way. It is hardly necessary to point out that no one ever does, in ordinary life, formulate sueh a principle as the basis of locating objects in mirrors. Indeed, no one ever thinks about his past experiences in any explicit way. Past experienees have been boiled down into a very safe and praetical habit of interpretation. We see objects straight ahead. But now notice the interesting faet that our interpretation of objects seen in mirrors goes further than this. We have, as I said a moment ago, a double interpretation. If we see the frame of the mirror, or if we recognize the presence of the mirror in any way, we know enough about mirrors to interpret our mirror object as a reflection, not a real object. We interpret the light as coming from straight ahead, but we interpret it as coming from what we know through experience to be an image rather than 
a thing. A savage does not have this added experience which enables us to interpret our experiences in mirrors as images. He takes the image for a real object. We do the same when we fail to notice the mirror. In both these latter cases the interpretation is not double; it is simple, and based on the more common fact that in all our past experience light comes in straight lines and from real objects.

I hope these illustrations have made it clear to you that present meanings are not identical with memories. Our way of looking at things is indeed the product of past experiences, but past experiences are not reproduced in full in the vast majority of our interpretations. Past experiences are worked over, epitomized, condensed, or whatever you please to call it, if you will only recognize that our modes of getting at present meanings are wonderfully economical means of guiding us. They bring all the past into our present lives, sifted and arranged for immediate use.

Indecd, if you will consider carefully you will see that such condensation is just as important a condition for progress as is retention. Suppose every time we were confronted with an impression, we had to go through a long process of passing in review in memory all the related facts out of our past. We should never progress. It is because we do not have to carry the uscless parts of this past into the future, because we have the powcr of selecting and appropriating what we need, that we can profit by past experiences without being burdened with the experiences in full.

If we may borrow an illustration from the life of a nation, we may say that history is the nation's mem- 
ory of itself. History aims to bring up the past as fully and accurately as possible. It will expend its highest energy in the effort to reach completeness and fidelity. If you would learn, on the other hand, what are the experiences from which the nation has profitcd, what are the lessons it has carried over into a condensed and immediately useful form, then you must study the present institutions and the life of its people. Our thought, for example, of what an executive head of a nation should be, is expressed in our President. Our President is, to be sure, at the same time an expression of what our fathers, trained under kings of Europe, thought an executive should and should not be; but the chief office of our nation is not an historical record, it is a present institution, an embodied result of condensed experience. It is understood and appreciated in our national life to-day, not because of its reference backward, but because of its present value and utility.

In an analogous way our understanding of a familiar word, such as the word danger, for example, is not due to memory of what that word has been known to mean in the past. When one hears the word danger shouted behind him, he begins to get out of the way. The word with its meaning is a living, present factor in his life, with present meaning and rich content. Experience has entered into the word, of course. You might shout "Danger!" behind an infant indefinitely and the chances are you would get a smile as return for your precautions. But though the meaning of the word danger has been learned through experience, one's present knowledge of that meaning is not to be described as memory; it is much more direct, and therefore much 
more uscful; it is what we have called present meaning.

When we compare memory and present meaning, we find that present meaning is usually the result of morc extended development than is found in cases of memory. 'Thus in the illustration which we used some time ago, of the mental processes which arisc in the cases of meeting a comparatively new acquaintance and of mecting a familiar fricnd, memory is evidently drawn upon in the case of the new acquaintance, bccausc sufficicnt experience for direct interpretation is not yet acquired. So also in lcarning new words. One has to go through the memory pcriod in order to reach the interpretation period. This is especially obvious when one tries to lcarn a foreign language. One finds it nccessary to stop and think of meanings, to recall slowly and laboriously what he has lcarned. In later, fuller acquaintance with words, one will bccome freer and freer from the necessity of remcmbering. Spencer has stated this fact in regard to memory and interpretation very clearly in his Principles of Psychology, ${ }^{1}$ wherc he writes: "Memory, then, pertains to that class of psychical states which are in process of being organized. It continues so long as the organization of them continues, and disappcars when the organization of them is complete."

One might spend a long time dwelling upon the importance of this statement of Spencer for educational practise. If it be true that memory is a stage of incomplete mental development, that there is a higher and

${ }^{2}$ Vol. i, p. 452. 
morc perfect form of organization beyond memory, then the fact must be recognized as important for school work. Certain it is that school work has no right to stop when it has trained memory. It must go on to the higher stage, which we have called recognition of present meanings.

There is, however, a much more significant question about the relation between memory and interpretation than this which wc have answercd by saying with Spencer, that memory, when it is present, is an incomplete phase of development. The question which our present-day education is most eagerly asking is this, How far is there any real nced of memory in giving present meanings? May we not pass to present meanings, it is asked, with much greater directness? Some of us are not asking this question in words, perhaps, but we are asking it in a practical way when we try to reduce to a minimum the memory work in our daily teaching of the children. Can we get along with less memory, asks one teacher, when he does not spend much, or even any, time in repeating the multiplication table. Can we get along without the greater part of memory drill, asks another teacher, when he says he would rather develop power in his pupils to deal with experiences as they rise, than cultivate memory of any number of facts which can not be put into immediate use. And so on through the whole list of modern educational reforms, we find this question of memory versus direct interpretation, one of the most vital questions in all our thinking and teaching.

It is a question which certainly deserves discussion from the point of view of the teacher's own mental life 
as well as from the point of view of the teacher's work. How much of our training in methods of teaching, for example, do we owe to memory, and how much do we owe to what we like to call tact or spontaneous powcr of dealing with situations when they arise? I hardly need to remind you that the common answer to this question in regard to the training of tcachers is, like the common answer to the question in regard to the training of children, much in favor of direct ability to interpret and control rather than in favor of memory. So from all points we come to the question, How can direct interpretation be gained with the least possible delay, with the least lingering at the lower level of memory?

There nced be no hesitation in giving the answer to this question. The amount of memory drill necessary in order to secure immediate interpretation is reduced just in the ratio in which practical and immediate contact with impressions is increased. Direct handling is the great means of training by which we can obviate the necessity of memory work. The method of learning what things are by using them, is so distinctly the modern method of learning that we all understand its cardinal virtues. Some of the games which we learn almost entirely by practise, and hardly at all by precept, are perhaps the best illustrations of the avoidance of memory work in adult education. If one wants to learn tennis, for example, he commonly goes out and tries to hit the ball. When he succeeds, it is due to the fact that he has tried a variety of ways of reaching the ball and has finally found the right response to his prescnt impression. Success is in a measure the result of past 
failures, and certainly each success will lead to a higher level of proficiency in the future. But one does not remember in any great degree these various experiences which perfect his ability as a tennis player. He just keeps on trying, each time coming a little nearer to what he regards as a satisfactory degree of proficiency. Again, consider the experience of learning to ride a bicycle, which is much like that of playing tennis. Other examples are, learning to swim, learning some trick of manual dexterity, such as tying a complex knot. In all these cases one learns by trying. Each experience is incorporated at once into present meaning, the useless parts of the experience being dropped on the spot, and only that which is thoroughly assimilated being carried away. That is, if the trial is not successful it is rejected, and just in so far as it is successful it is retained as a present mode of acting in a given situation. The last and most successful movement is recorded in such cases, not in memory images, but in the form of an acquired habit.

Memory is not needed in the cases we have been discussing, because memory would carry forward too much. If memory shows itself at all in such cases, it is usually in the very undesirable form of a haunting recollection of some disastrous failure, which contributed to education only in the most remote and negative way. That the final successful movements are not retained in memory, you can make yourself realize by trying to tell somebody else how you performed the successful move. For example, try to explain how you tic a knot, and see how little is retained in memory. On the other hand, the habit never fails, in spite of your 
inability to reeall how you aeted the last time and the time before. In the presenee of proper eonditions of string and free ends you feel that "warmth and familiarity" of experience whieh marks it in your mind as an experience which you ean easily and direetly interpret and manage.

One can avoid memory work through training in the use of things. This is the observation which experienee forees upon us at all points, and this is the principle that our modern edueation is so eagerly taking up in all departments-in the kindergarten, in the eonstruetive work of the elementary sehools, in manual training, and in the laboratory work of our high sehools and eolleges. Learn by use, learn by doing, and you shall have followed the shortest route to reeognition of present, practical meanings.

And now I believe that we have said what there is to be said in favor of making present meanings the goal of mental development. We have, up to this point, shown our willingness to join the ranks of those who are striving to improve modern education by making it less a matter of mere reeolleetion of earlier experiences. It is time, after all this emphasis of immediate training in present meanings, to point out some of the limitations of this sort of training, and to say something in faror of a rational form of memory work; for while we should be ready to eorrect the abuse of memory work in the schools, we should never be so far absorbed in this campaign against memory work as to try to put entirely out of the schools all forms of memory training. Memory work rightly planned and earried out eertainly has a plaee in our school life, and there is danger in our 
modern pedagogy that we shall be too radical, and shall lose some of the great advantages that come from the cultivation of indirect, memory interpretation.

The great limitation set upon the value of training that includes no memory is that it is inflcxible. Immediate interpretation without memory is the mechanical side of thought. It proceeds on its way without variations. Lct me illustrate this by referring again to such forms of interpretation as one has when he looks into a mirror. In past expericnces the light has so regularly travcled in straight lines that we have a fixed mode of intcrpretation. This mode of interpreting light, either ncver had an immature memory stage, or else it very soon passed beyond memory. It is as immediate and complete as any form of recognition of meaning possibly could be. Notice that it does not admit of change cven when we know, as in the ease of a mirror, that the conditions are changed. We avoid inconvenicnce in dealing with mirrors by superimposing upon the original fixed mode of interpretation a seeondary, or added clause of interpretation, adapted to mirrors as special faetors of experience. In other words, we do not attempt to change the first mode of interprctation at all. We let it stand as fixed and safe for most purposes, and simply say to ourselves that it is, after all, not true that the object is back there as we sec it in the mirror, that as a matter of fact the object in this case is around an angle.

The fixity of our interpretation of the direetion in which light travels would also get us into trouble if we had to deal very frequently with objeets under water; for, as you know, a ray of light is bent in passing from 
water into air. But here, too, it is easier for us to think our way through such unusual eases than to modify our general mode of interpretation. We see objects which are partly under water and partly above the water as if they were bent, but we do not disturb ourselves on this account; we have learned to hold in memory the eorrection that objects are not bent as they seem to be. We thus make our interpretation by addition, not by any modifieation of the fixed form of ordinary pereeption.

Relatively fixed modes of interpretation which have passed more or less eompletely beyond the memory stage-that is, beyond the possibility of modificationare more common than most of us realize. Such relatively fixed modes of interpretation are not always as unchangeable as is our mode of interpreting the direction from whieh light eomes into the eye. They are sometimes eapable of ehange under very strong provoeation, but the provoeation must be indeed great. Thus, most of the people we deal with are fixed, so far as our estimate of them is eoneerned. It would take a great deal to induee us to think well of some people or ill of others. Even if a man whom we do not like does a good thing, we refuse to see it as good. Our mode of interpretation is too fixed. Political faith is proverbially fixed. If one is a stanch partizan he will see things in a way appropriate to his partizan interests, and arguments avail little to change him. In matters of social practise, in matters of taste, and even in matters of religion, we find ourselves fixed and immovable, and our grounds for being fixed passed so long ago out of memory that we ean not give an 
account of the origin of the mode of looking at things which we now adopt.

If you will study the way in which onc of these fixed habits of intcrpretation begins to break up when the sufficient provocation arises, you will see the value of memory. Some fact presents itself which refuses to be interpreted in the old way. If in such a case onc can by recollection call up the grounds of the fixed mode of interpretation, he may place the new fact alongside of the older considerations and may formulate a new and broader mode of interpretation. Have you not heard some wise political orator saying to a stubborn audience of opponents: "Let us consider why you bclong to your party. Do you not remember how your father was a member of that party, and how it did thus and so in the good old days? Ask yourselves whether it is doing the same to-day." What is our political orator doing? He is putting us back at the beginnings of this political faith of ours. He knows very well how difficult it is to rcadjust the fixed habit of maturc interpretation, even when readjustment is nceded, and he knows also how much casicr cliange will be if he can oring us back to the beginnings of this mode of thought. In short, he is playing upon the variable element of our mental natures, and that variable element is memory as opposed to fixed interpretation. Memory is characteristic, as Spencer put it, of those psychical processes which are in the stage of formation. If you can get at the memory stage of interpretation you can change it.

I suppose you are already asking yourselves the quesion to which our discussion has now brought us: Is it 
advisable in the eourse of education to keep any of the modes of interpretation open to the possibility of easy revision? The answer to that question can hardly be anything but an emphatie Yes. There are a very large number of interpretations which need eonstant revisions. Thus, every time a pupil passes from an elementary stage of a seience to an advaneed stage, there must be a readjustment of ideas. For example, in passing from the arithmetieal to the algebraie methods of dealing with the number idea, a very great enlargement of the number idea must take place. The transition from physies to its applieations in meehanieal engineering, is another illustration of a more practical type. Our social ideas very often need readjusting. Take, for example, all our habits of thought about our fellow men. Take our politieal interpretations. I remember an old fellow in the country where a part of my boyhood was spent who had voted the ticket of one party all his life. On one oceasion a friend of his in the opposing party was nominated for some petty local ofliee. The old hardshell worked faithfully for his friend until election day, and then the habit of thought and action of a lifetime was too much for him, and he went to the polls and voted against his friend, whom he recognized as after all out of the true fold. Such an example as that illustrates, more eloquently than could any argument, the necessity of kecping one's modes of thought ready for revision. If you want to aroid beeoming a fossil in any line, keep the rcasons for your habits of thought sufficiently fresh in memory to make it possible to reeonsider them from time to time. 
Take the questions of how teachers shall arrange eir work for the class room, and what their methods instruction shall be. Have you not scen teachers ho have thought in certain ruts with such rcgularity rery time a certain subject was presented, that they have come petrified? Given a boy of twelvc, a problenı percentage and a blackboard, and such a teacher can ot see or expect more than one result, and that result ust come in a perfectly fixed, definitc way. If some ne comes from some other school and says that this ethod is not right, what can our teacher with the xed mode of thought do? Nothing. He does not reember now why he adopted the method. It is fixed, at is all there is of it; new methods are not wanted.

Mark you, I do not say that every time some one mes to you with a ncw method you should adopt it. that I do say is, that if you want to kecp yoursclf from etting into bad ruts, you must be intclligent about hat you do and about what you think; and the way be intclligent is to be able to remember why you do, ad think, as you do. Pcdagogy is little if anything ore than a means of waking a teacher up to the impornce of understanding his or her own modes of thought ad action. Why does a child mean this or that to you? hat are your rcasons for your attitude toward your upils? Why do you think geography is an important abject? Why do you use the inductive method? Why e you prejudiced against manual training? These e questions which, if you can not answer, you are a ave to blind attitudes of mind. You may even be a fair acher and not depend on anything but these blind ad thoroughly established modes of thought, but the 
chances are against you. You should give your habits of thought, as I said a moment ago, a periodic looking over, and, if necessary, a periodic revision.

And what is true of teachers and other grown-ups is true of children. They can learn to be in a sense expert by the mere methods of trial and retrial, by the methods of practical manipulation. They can be intelligently expert, however, only when they add to their ability to do things, some knowledge of how things are done and why they are done. In the good old days, boys were sent out as apprentices, and they learned by. trial. To-day we give our boys a thorough course, in which, if we are wise, wc mix with trial some memory work. I think that the day is not distant when we shall recognize in all departments of our teaching that memory work has its large and proper place along with the more direct forms of learning. And for ourselves, I think we can find, if we study the matter closely, as we shall try to do in the next chapter, that many of the great difficulties that beset teaching are duc to the fact that teachers do not try in a practical way to be something more than routine tcachers; they do not try to keep alive their memories and to understand the reasons for their present modes of looking at their cxperiences. 


\section{CHAPTER III}

THE ORIGIN OF SOME OF OUR EDUCATIONAL IDEALS

Is one of his letters, Stevenson sums up the discouraging side of educational efforts by saying that one must keep chopping and chopping and never have the satisfaction of seeing the chips fly. What teacher has not realized keenly at times this feeling of vagueness and uncertainty as to the effect of class-room and school work? We seek to render this uncertainty somewhat less trying by holding now and then what we call tests. We are ready to admit that these periodic tests do not give us an entirely satisfactory indication of what has been accomplished, but we want to see some of the chips flying, and so we get what meager satisfaction we can out of examinations.

How different it is in other callings! The carpenter looks over his work as it progresses day by day; the merchant takes his inventory and account of stock at least once every twelve months; the lawyer knows when the verdict comes what has been the effect of his plea; the doctor finds his patient better or worse; and so on through the whole list of professions and occupations. The results are obvious, and they come soon enough to serve as guides for new efforts. If this or that method of treating a disease does not produce the desired re- 
sult, the doctor soon knows it and changes; if this or that method of advertising is successful, the merchant soon finds it out and develops it more fully. With teaching it is different. We think we have a new and most successful method of teaching, and we use it with unrestrained enthusiasm, only to find that the children on whom the method has been tried are being hindered in their general mental development by their special devotion to this one subject. One can not cast up accounts in matters of education until that far-off period when the boys and girls shall show themselves well or illy equipped for life outside of the schools. And even then, who shall separate the results of school training from the results that grow out of the influence of home and sociat life? Surely the teacher's task is one in which it is not easy to weigh and measure methods and results.

Did you ever consider the effects of this remoteness of results on the teacher's conduct and mode of thought? Of course we all realize that just because we are not brought to a practical test day by day, we are, more than most people, open to the temptation of shirking. But I do not intend to dwell on that phase of the discussion. I wish rather to assume that a teacher has unlimited devotion and untiring zeal, and to point out that even under these conditions, the remoteness of the end of education has its marked effect on thought and conduct. The best way, perhaps, to describe this effect is to say that, deprived of the obvious guides which the carpenter, or merchant, or members of other professions have, we as teachers are dependent on the ideas which we hold as to our aims and purposes. In other words, 
we set up as substitutes for unseen and remote ends, a variety of theoretieal ends. We do something to-day and to-morrow, not beeause we expeet to find our efforts ripening into immediate fruition, but beeause our thoughts as to what we should aeeomplish lead us to take this step and the next. I think sueh a line of eonsideration as this serves to explain and justify very fully the large amount of discussion which edueational questions are everywhere reeeiving. Certainly there is no profession more in need of good ideals and strong ideals than is that to whieh we belong.

So neeessary, indeed, are ideals to guide the work of the teaeher, that history is full of illustrations of the faet that where no earefully thought-out edueational ideals have been at hand, the neeessary ideals have been seized up from this or the other outside source and have been made to stand as guides for pedagogieal endeavor.

Let us consider in detail one of the best historieal illustrations of such borrowing of ideals. Just at the beginning of the eighteenth century there grew up in the little German eity of Halle an edueational movement whieh was destined to have a far-reaehing influenee on the development of Germany's sehool systems, and indireetly on the development of our own sehool ideals. An enthusiastie professor in the University of Halle saw what seemed to him to be the possibility of developing a new and more practieal form of sehool work. He organized a sehool for waifs, and attaehed to this general sehool, a training-school for teachers. The results of this movement are still alive in a vigorous normal institution bearing the name of the founder 
of the earlier school, the name of Franke. Franke's school made some innovations in the subjects chosen for instruction and in the way of teaching these subjects, but in these innovations we shall not interest ourselves now. The fact of chief interest to us here is the thoroughgoing application of a certain narrow religious ideal which Franke worked out in the organization and discipline of his pupils. "Play," said Franke, "must be forbidden in any and all of its forms. The children shall be instructed in this matter in such a way as to show them, through the presentation of religious principles, the wastefulness and folly of all play. They shall be led to see that play will distract their hearts and minds from God, the eternal Good, and will work nothing but harm to their spiritual lives. Their true joy and hearty devotion should be given to their blessed and holy Saviour and not to earthly things, for the reward of those who seek earthly things is tears and sorrow."

There is something strangely narrow in that ideal which Franke set up for the discipline of his pupils. We shall miss the significance of Franke's work, however, if we fail to recognize that this was with him a true and clear ideal. It did not arise from any careful study of children; it did not arise from any broad historical study of what education had been; it sprang rather from a deep religious conviction. It was an ideal which the teacher relied upon to guide him in the task of preparing his pupils for life here and hereafter. It was an ideal which I dare say Franke himsclf would have admitted was beyond the possibility of any immediate test. Indecd, it was enthusiastically adopted by 
him just because no test was undertaken of the value or limitations of play. It was a borrowed educational ideal.

And now that you have seen the narrowness of Franke's educational ideal, borrowed from his religious beliefs, let me ask you whcre our own ideals of play came from? Or, to relieve the discussion of direct personal applications, take the schoolmaster of a generation ago; what did he think of play? I remember some of my own experiences which lead me to believe that if some of my teachers were not inspired by profound religious zeal, at least they were inspired from some other source, perhaps opposite to that of Franke's inspiration, by prejudice against play equal to that of Franke, if not exceeding it. The changes which our own ideals of play are undergoing at this very time serve to call our attention as teachers most emphatically to the prejudice against play so prevalent in the schools of yesterday, and give us at the same time good ground for the question, Whence came these earlier educational ideals, and whence are coming the newer ideals? In short, we have here a phase of the large question of the teacher's professional ideals. Whence do they arise, and what are they?

Professional ideals are to bc distinguished from ideals in general. There are some teachers who have a kind of schoolroom manner and mode of thought, different from the manner and mode of thought which they carry into every-day life; these teachers illustratc the strength of special ideals adapted only to the professional life of the teacher, and unfortunately they illustrate too often the peculiar and narrow character 
of these special ideals. Professional ideals are not, however, always bad. The term " professional " refers to all these speeial ideals about the aims of edueation whieh we as teaehers take up from this souree or that, and use to guide our steps along the by no means obvious path of educational work. Very frequently we do not realize whenee these idcals eame, or how appropriate or inappropriate they are as guides. They are like the modes of present interpretation of whieh we spoke in our last elapter, always present in developed mental life, but frequently so far beyond the memory stage that their sourees are forgotten and the possibility of ehanging them is very limited.

Many of our professional ideals are borrowed from tradition; sueh ideals have, in a double sense, passed the stage of memory. In the first plaee, those who transmitted the ideals to us have commonly lost sight of their first sources; and in the seeond plaee, we have forgotten in turn whenee we drew the tradition. We teaeh, in short, as we were taught, and we do this because it is easier to take up with ready-made ideals than it is to make new ideals for ourselves. When some educational thinker steps out with a new ideal for the school, we all stand back and refuse to have anything to do with the new ideal. If we recognize his proposition as a eall to defend our old views, we find out very soon that the justifieations for these older views are long lost in misty antiquity. The eurious fact is, that even if we do become eonvineed of all this, we do not, or ean not, muster energy enough to reopen the whole question and revise our ideals in the light of the new facts. Or, at least, to put the case somewhat more 
mildly, the process of revising our ideals is exceedingly slow, and requires a generation or two before new traditions can grow up. Would that we might have a body of teachers so well informed as to the traditions of their profession, and so constantly in touch with the helpful new considerations, that revisions of educational ideals would not be so difficult and tedious! And this is, in other words, nothing but a plea for more study by teachers of their own ideals and of the grounds of these ideals.

By way of illustration, let us push that question of discipline in the school a little further than we did in our discussion of Franke's methods with his children. What is your ideal of good order? Where did it come from? I venture to say that we all of us have a notion that we are not responsible for the imposition practised on children in the schools. This idea, to which we cling more or less tenaciously, of making children sit in one place for long periods of time, is gradually being given up, it is such an ignoble failure. But how many gencrations of children have suffered in the years past because of this notion of order, a notion which any intelligent mother could have told teachers was, to say the least, defective!

By way of contrasting other idcals of order with our own, it is intercsting to know that in the schools of Hindustan and of many other Oriental countries, the boys are allowed to sway backward and forward and to read aloud from their books as they study, each in his placc. The way in which the teacher picks out the good boy there is to select the one who is wiggling most energetically and talking to himself the loudest. They 
have a form of order which agrees with our view that doing is essential to the learning process, very much better than does our own form of order.

Even in the old Roman school, from which our schools borrowed much, the boys had far greater freedom than in the later medieval schools which followed the Roman schools. As Laurie puts it in his history: "The pupils seem to have spoken out loud when learning, and the masters outshouted them." Our ideal of order evidently did not come from this old Roman school.

Furthermore, the changes we are now making show that our older ideal did not come from a careful study of children and their needs.

We sometimes try to justify the ideals of rigid order by saying that quiet is necessary to concentration of attention, and bodily repose is necessary to mental activity. But all this is shallow fiction. Bodily activity is always present in connection with vigorous mental activity as we shall see more in detail in our later discussions. Indeed, in children this bodily activity is of a very pronounced type. We are coming, as every student of present-day education recognizes, to see more clearly the necessity and value of proper movement as an aid rather than a hindrance to education. And as to the necessity of quiet for mental concentration, do you think your boys and girls will get quiet when they go into the activities of real life? And if not, do you think we are preparing them best for life in our quiet schoolrooms?

No; if we are to understand the present organization of our schools, we must go back through the cen- 
turies, stopping for a moment to see how the stern Puritans of New England enforced the law that all things pertaining to this life are trivial and fit only to be eradicated by the schoolmaster. We must pay our respects again to Franke and his school; we must go back of the Reformation, with its schools for the people conducted on the same plan as the earlier church schools. Here in the church schools we have the beginnings of our modern ideals in more than one particular, but in no particular more clearly than in the matter of discipline. The medieval schools conducted in connection with the cloisters were organized on the same stern principles as the whole life of those institutions. The silent monks, given over to meditation, withdrawing from the frivolous and untutored world without, these were the only schoolmasters of that day. They marched to and from the service with bowed head and lips moving only in silent prayer or devout hymn. They learned the words given them by the authority that presided over them. They suffered in confinement and with cruel tortures for the slightest infraction of the laws under which they lived. All this they thought to be necessary in order that they might free their spirits from degrading association with the unspiritual body. And when they took boys into their cloisters to preparc them for intellectual and spiritual life, these zealous monks naturally followed in great detail the lines of discipline through which they themselves had come to their high estatc. What did these sequestered monks, cut off from all the real life even of their own times, know about the child's nature? To them the child was nothing but a soul to be savcd at any cost of sclf- 
sacrifice and mortification of the body. To them anything which looked likc play was a reminder of the vulgar, wicked world outside the cloister walls. To them sternness and severe discipline were the only means of salvation. And since their day, teachers have gone on accepting this false notion of play and school discipline. Now and then there have appeared extremists like Franke, or like the teachers in the Port Royal schools in France, or like the Puritans in our own New England-all of whom have tried to be more consistent than most of us. These cxtrcmists said that if our school discipline is right it should be extended so as to cover all the hours of the day; no half-hearted compromise like ours of half a day of play and half a day of severity would do for those eager souls. And then, on the other hand, there have been men like Robert Ascham, who have pleaded for humanity and mildness. There have been men like Rousseau and Froebel, and a host of others, who have said to us in no uncertain terms: Give up the harsh and artificial rigor of the school. Bring back this institution to real living and natural enjoyment, and let us recognize the children's rights of body and nervous organization as well as of what we call soul.

The trouble with us as teachers has been in the past that we have never waked up to the fact that our idcal of order is a mechanical, traditional idea. I am not going to say that the new ideal on which we are working in our American schools will not contain something of the spirit of the old sad-eyed monk's view of life. There is some truth to my thinking in that medicval idca, carried in those olden days to an extreme 
and accepted blindly by generations since. But that truth must be mixed with other truths. The other truths are rushing in upon us in these days. They come from child-study, from our study of biology and sociology. We are learning the lesson that an act does not need to be disagreeable to be virtuous, that pleasure is compatible with highest effort. And it is possible that we are being a little carried away by these discoveries. If the old monk was a hard master, some of our modern schoolmasters have adopted what Professor James has so aptly called a "soft pedagogy." This violent swing from one cxtreme to the other is due to the fact that in ncither case is the idea an intelligent one. It is adopted blindly from tradition, or it is seized up from modern science. Teachers need to become more intclligent as to the grounds of their practises.

If we turn from school discipline to the matter of instruction, we come upon a group of traditions that it is almost impossible to bring teachers to realize are mechanical and often dead. A subject of study gets itself petrified very rapidly. One generation learns it in school in a certain way, and when that generation has grown old enough to be in charge of the work of tcaching, it is almost impossible to introduce a new elcment or phase of instruction. If you ask why we teach. thus and so, you will be confronted with a whole serics of artificial excuses; the real reason is that we, as the older generation, are so fixed in our modes of thought about the subject in question that we can not realize that there is any rational ground for change.

Take such a question as that of the desirability of changing the character of gcography in the schools. 
I have seen whole bodies of teaehers protesting against eommereial geography. They have tried to brand eommereial geography as mereenary and materialistic. They have tried to point out that there is less exaetness and less discipline in sueh study than in the minute scrutiny of the map which used to be demanded. Such teachers would rather loeate the most northerly town in the State of Maine, than know the way in which eotton is gathered and paeked for market. They would rather mark a pupil down for forgetting that one eorner of the State of Pennsylvania touehes Lake Erie, than teaeh a class how eoal is blasted and earried out of the mines, or how iron is turned into steel. It is not true that these faets of industrial life are unworthy of eareful study in the sehools. It is true that the average teaeher will not arouse himself to revise his notions of geography. I venture the remark again, that our teaehers are not so mueh intelligently opposed to the new demands made upon them by the new eurrieulum as they are blindly worried on imaginary grounds. A new geography is demanded of them. The traditions of a lifetime rise up in rebellion against this innovation. Nine times out of ten the teaeher begins by feeling imposed upon, and ends by rebelliously thumbing over the new requirements, and goes away worrying beeause the new requirements and the old ideals do not agree.

Whieh is right, the old ideal of what geography is and ought to be, or the new requirement? Again I shall venture to formulate the results of observation in the statement that probably neither the new requirement nor the old ideal is entirely right. They both need careful examination and criticism. They need 
intelligent study on the part of class-room teachers. The trouble in our school systems is that there is not cnough of this constant comparison in an enlightened way, of new demands and old ideals.

If in a large mercantile house the methods get ever so little bchind the times, the results show themselves in a falling off of profits, and there is a constant spur to keep one's eyes open in the observation and study of methods. But in the teaching profession there is no such constant spur. Onc may fall years behind and not realizc it. One may be so blind as to be quite unwilling to see even when the new subjects and methods are brought to his door. Or one may, if he will, be progressive, and realizing the charactcr of his own profession be his own spur.

I have used the illustration of geography first, because that composite science is so clcarly one of the storm-centers in our present-day discussions of education. Physical geography on the one side, commercial geography on the other; nature-study in all its manifold departments; political history and social scicnce as studies of the human institutions of which gcography used to give us a glimpse-all these new subjects are calling for recognition in a larger measure. These are the subjects under which tcachers are chafing. What shall we do with them? I think therc is only one answer that can be given to this question with any hope of bringing about a satisfactory solution. The individual teacher must examine for himsclf the new claims. He must bring out his old geographical ideals and prepare to undcrstand them. Above all things he must not put himself blindly on the defensive. Never hold to an 
cducational ideal as if it were infallible. Remember that it too has real grounds on which to rest, and the value of the ideal will depend on the validity of these grounds. Prepare to know the grounds, that is the rational line of defense. Do not turn this task over to the superintendent, especially if you have the mental reservation that, whatcver he concludes, you will hold to your old ideals.

The conflicts between reform and pedantry which we have scen so often in our schools, are due to the fact that one or both parties to the controversy are unable to see back of their particular ideals to the underlying justification.

One could pause and draw from history illustration after illustration of how bitter conflicts have been waged in breaking up petrified ideals not only in education, but in other realins of thought as well. We have a kind of admiration for the men who laid down their lives for the ideals represented in the crusades, when the nations of Europe determined to repossess the Holy Scpulcher. And yet, after all, the greatest good accomplished by the crusades was not the protection of the medieval religious ideal, but the renovation of this ideal. The verdict of history is clear. The crusades were blind struggles for an imagined and unsubstantial good. In that strugglc the medieval man learned the difference between the good to which he had falsely held and the real good. One can not read that lesson of history aright without applying it to his own lifc. We fight blindly for educational ideals, only to find in the course of the struggle that we were perhaps partly right, but seldom wholly so. Let us take 
the lesson as a warning against that kind of defense of our educational ideals. Let us do the intelligent thing, the rational thing, and before we become militant and rush to arms, let us use our minds, which we as teachers hold to be the safest guides in life.

It is hardly in place in a general discussion of the tcaeher's attitude toward the subjects in the curriculum to devote much time to the detailed discussion of the separate subjects themselves, and I shall reeognize that limitation of our present opportunity. I shall not entcr into any defense of nature-study and commercial geography, cxcept to repeat an incident which seems to me to be full of the kind of meaning whieh my whole argument has tried to convey to you. I once had the opportunity of speaking to the teaehers of a small Ohio city in defensc of certain changes which had recently been introduced by a new superintendent into their course of study. The argument ran something like our present argument. The accepted studies of our curriculum have not always been the aecepted studies. Arithmetic was once rccognized as valuable for school discipline only in so far as it was necded to make possible computation of the ehurch calendar. Geography of the sailor type is a comparatively recent subject. The carlier forms of geography used to be more like our present astronomy. And so on, I was trying to show how the school course is a gradual growth, and was drawing the conclusion that what has grown up to its present stage of development must be expeeted to grow further. After that teaehers' meeting was over an old gentleman came up and said to me, "Young man, you might have made your state- 
ments a little stronger if you had had the experience of one as old as I am. I can remember when a young New England girl who had come to teach in the school which I was attending, introduced a new subject into the course of study of that school, and that new subject was geography. There was a good deal of excitement about it in the community and much skepticism on the part of the sages as to the propriety of the innovation. Especially the teacher in the next district was disturbed that the good old traditions of the schools thereabouts were thus ruthlessly set aside by that young New England girl." I asked the old gentleman what the outcome was, and he laughed and said for his answer that his daughter was now teaching naturestudy in the school.

Of course geographical ideas are not the only ones that are getting a renovating these days. We do not have to go far into any of the lines of instruction to find changes. I shall content myself, however, with reference to one of the more general of the proposed changes in the course of study. Why is there such opposition to the new ideals that are being offered to us in the so-called constructive work, or manual-training courses in the schools?

The common attitude toward constructive work can be discussed from several points of view. In the first place, we may undertakc a description of what the attitude really is in the mind of the average teacher. And here I think we may safely say that most of us think of constructive work as a sort of secondary mode of training, closely related to pure physical training or even to recreation. We seldom find a teacher who 
would be willing to defend the position that constructive work is coordinate in importance with reading or arithmetic. We usually think of constructive work as less intellectual than the other subjects mentioned. We think of it as less ennobling, as less characteristically human, as less highly developed. Consequently, we fecl at liberty to neglect constructive work more than the other subjects. We do not feel that it is anything of a stigma upon oursclves when we admit frecly that we are not able to conduct constructive work successfully. If too much of this kind of work is demanded of us, we chafe under the requirement and wish for a special teacher to relieve us of the work.

Another point of view from which we might discuss constructive work is that of the teacher's equipment. Most teachers are not prepared to take up such work. They possess no manual dexterity, no knowledge of tools and materials, no imagination with which to plan such exercises, and worst of all no desire to correct any of these limitations.

Again think of the relation of constructive work to our present school organization and equipment. Our desks are not adapted to such work. The arrangcment of our desks in the rooms is not suited to it. The supplies ordinarily furnished by boards of education do not include the necessary tools or raw materials for constructive work.

Finally, from the point of view of the parents of the children, constructive work is not what is expected of the schools. I once heard an irate parent sum the matter up by saying that his children did not go to 
school to cut and fold papers or whittle wood-they could do that at home without the help of a teacher.

Certainly such considerations as these which we have been briefly summarizing, show beyond the possibility of doubt that constructive work is not a fully accepted or willingly accepted innovation in our school work. Men may argue as they will at teachers' meetings and in the educational journals about the advantages which arise from the introduction of constructive work into the school. The simple fact is that most of us listen to these arguments in the proverbial fashion, with both ears, one ear serving, however, as an exit for what comes in at the other.

Why is it that an average teacher is so prejudiced from the outset against constructive work? I find it very much more difficult to give a definite answer to this question than it was to give an answer to the question of the source of our ideals of school discipline. The difficulty of accounting for our prejudice against constructive work in the schools lics in the fact that this is not a prejudice peculiar to teachers. It is so wide-spread, I was about to say so universal, and so old, that it is impossible to get at the special period when it came into the school or even had its origin. The fact is that men of all classes have long drawn a sharp contrast between bodily activity and mental activity. The Hindu devotee who sits in one position ycar after year busy with high and holy thought, the Greek laughing at the philosopher so lost in meditation that he clumsily falls into the well in his path, the religious ascetic of the medieval world who sat and gazed for hours and even days into blank space-all these are 
witnesses to the antiquity of the contrast between bodily dexterity and mental activity.

Taking up the matter from the point of view of the science of psychology, especially from the point of view of the psychology which has been written by the so-called English school, mental life has been treated for the most part as if it were made up of impressions and of ideas resulting from these impressions. Until very recently no one thought it necessary to say very much about expression, or the active side of knowledge. If expression was mentioned at all in the earlier psychologies, it was treated as a kind of unessential after-effect. Thus we have all of us come to think of action as something which one may or may not enter upon after he has had a thought. We consider the thought as a kind of taking-in process, and as a kind of turning over in the mind of what is thus taken in, but we have not been in the habit of expecting action unless the thought is supplemented by a process quite apart from the thought and additional to it. We all of us tend even now to believe that one may think intently and be perfectly inactive so far as his expressive muscles are concerned. In short, the tradition of our psychology, both scientific and popular, has been that bodily dexterity and mental life are distinct and separate.

I suppose that it will require a generation or two of teachers to root up these ideals and to clear the way for a new and better ideal in the art of teaching. I suppose that the strongest evidence will have very little force in assaulting this stronghold of tradition, and so I shall feel quite satisfied with the results of 
my efforts during the remainder of this chapter if I can only set you inquiring into the validity of your idea as to the relation of mental life and movement.

In order that there may be no ambiguity as to my position in the matter I will say to you frankly at the outset that I belicve we have been all wrong in this matter. I believe we have cnough facts now to makc it perfectly clear that bodily movement is present in a very pronounced form whenever there is mental activity, and I believe it can be shown that the training of this bodily movement is an essential part of the general training of the individual. If these beliefs are justificd by the facts, then the conclusions will not be very difficult to draw, our educational ideals are sadly in need of revision, and the sooner we can effect this revision the sooncr we shall undo the harm that has been done by accepting a false ideal.

Let us turn now to a consideration of some of the facts which support the statements just made to you. There is a very simple experiment which any one can easily try. Take two bottles of different sizes, cover them so that one can not see what is in them, and then put shot into the smaller one until it is exactly equal in weight to the larger, empty bottle. Then take up the bottles in your hands and you will find that, in spite of your knowledge that the two weights are the same, the small bottle will seem very much heavier. That is, you are subject to what we have already learned in another connection to call an illusion. It requires no great degree of insight to see in a general way what is the cause of the illusion. There are plenty of other illusions of the same type. You take up a small bottle 
of mercury and it will seem very heavy, much heavier than you expected from looking at the bottle. The sudden difference between what you expected and what you really get in the way of a sensation, increases very much the effect of the weight. We say that the apparent weight has been inereased by contrast. Now, in our experiment of the two bottles of the same weight but of different sizes, there is such a eontrast. Bottles of different sizes are commonly different in weight. But if the expected difference in weight does not really appear when we pick up the bottles, then we are led through eontrast to perceive just the opposite of what we expected.

There is a not uneommon trick whieh is of the same type as this illusion of the bottles. Fire or six of us stand around some person who lies on two chairs and at a given signal we each lift with one or two fingers of each hand, and the person seems to be very light. We do not pay attention to the fact that the weight is distributed so as to be very little for eaeh of the lifting fingers. We expect to lift 150 pounds, we aetually lift about 15 pounds or less with each finger, and the result is we do not notice the 15 pounds as being at all heavy. The eontrast between 150 and 15 is great enough to account for the whole illusion. The holding of one's breath and the other mummeries that are generally added to the experiment, help to distract one still more from the 15 pounds that have to be lifted and so aid the illusion even further.

Up to this time we have spoken of these illusions in the usual terms of impression and mental contrast, and I venture the guess that most of you have thought of 
mental eontrast in this eonnection as a sort of conflict in the mind between what is expected and what really came in. That is, you have been satisfied to think of the whole matter as a mere eomparison of impressions. But there is a great deal of bodily aetivity involved in this illusion of whieh the explanation by mere impression does not take aeeount. When you looked at the two bottles, or when you prepared to lift the person lying on the chair, the sight impressions that came in at your eyes were not the only facts whieh we need to eonsider. Your conseiousness went beyond the impressions and interpreted them. The interpretation involved as its most important faetor in this ease, a recognition of what you eould do with the objects at which you were looking. What you eould do was added to the incoming sight impressions and your real idea of the objects before you was not merely "that thing," but it was rather "that thing whieh ean be lifted with more or less effort." Even before you did any actual lifting your impression was joined to the possibilities of expression. In some other eases, the expression faetor is more elaborate. For example, if one of the bottles is full of medicine and you look at it, you see not merely "that light-eolored bottle whieh ean be lifted," but you see "that light-eolored bottle whieh is to be turned up and a part of its eontents swallowed." In other words, there is no idea whieh is made up entirely of mere impression; there is always a factor of expression. This factor of expression is so closely related to one's personal use of the objeet that we may say that the personal phase of all knowledge is the expressive phase. It is because there is something that I can do with ob- 
jects that these objeets are of interest to me. Anything which I never ean use, is of little importanee to me, and I am sure to overlook it. What I ean use, I look at sharply. I reeognize, aeeordingly, when I look at such an objeet not merely its eolor or its form, but also its value to me. I add meaning to the impression in the manner deseribed in our last ehapter. And this fact of value or meaning is paralleled on the bodily side by an actual preparatory contraction of my muscles. If, as in the ease of the bottles in our experiment, the objeet is small, the eontraetion of the museles will be very slight, but it ean nevertheless be demonstrated as present by means of appropriate reeording apparatus. And what is of greatest importanee to us here is that the intensity of museular preparation for lifting agrees with our interpretation of the objeet as heavier or lighter. 'That is, in the ease of the two bottles of different sizes and like weight, our museular preparation is eontrolled by the different sizes, and we get ready in the ease of the larger objeet to lift a heavier objeet. When now, we do the lifting, the larger objeet seems light beeause our aetual museular preparation was too great and the objeet was therefore very easily raised. The eontrast, you see, is not a mere matter of eomparing impressions in the mind, it is a question of the kind of interpretation which was added to the impression, and the interpretation in this ease, as in every ease, involves certain faetors of bodily aetion. Bodily aetion is present before the lifting really begins, and before we reeognize that we are in aetion through any impressions of aetual movement. Bodily aetion is the expressive side of the experience. We see accordingly that an ineoming im- 
pression and the expressive intcrprctation, are mutually interdependent; that they supplement each other; and that together they constitute the total unitary experience.

The reason why we do not recognize in ordinary life the constant relation of bodily activities to impressions, is that we have a wrong notion of what goes to make up bodily activity. Most of us think of bodily activity as consisting in a movement of sorre of the external parts, such as the arm or face. We forget that there are ccrtain inner movements which are always changing with every incoming impression. Take, for example, the action of the heart. We all know that in extreme cases of strong or sudden impression, the heart beats violently, or seems suddenly to stop. We see the face grow red or white when the appropriate impression is received, even when there are no signs of external movement. What we see in extreme cases as noticeable changes in the action of the circulatory system, gives us a clue to the general fact which scientific investigation has fully established. This general fact is that cvery impression, be it ever so weak and insignificant, affects in its mcasure the distribution of the blood in the body. Put in other words, this means that one of the forms of bodily activity which regularly accompanies impressions is the internal change in the way in which the heart and the blood-vessels do their work. And this is a very large cxpressive factor; it is an important form of activity, cven if it does not involve external muscles of the hand and face.

One of the simplest ways of demonstrating the constancy and delicacy of these inner activities is that de- 
vised by Mosso, an Italian scientist. He balaneed a man so earefully on a balanee-board that the slightest inerease in the amount of blood in the head would be indieated by a tipping of the board downward at the head end. Then he found that even if he let the man go to sleep, and thus made him less susceptible to impression than usual, the slightest noise would have as its inmediate eonsequenee an increase of the amount of blood in the head. Just as hard study or exeitement results in a rush of large quantities of blood to the head, so a slight impression produees in its degree a slight inerease in the amount of blood. The earefully eonstrueted balanee-board showed what the coarser observation of ordinary life shows only in cxtreme cases.

What is true of the aetivities of blood circulation is true also of aetivities of breathing and of digestion. One has felt himself stop breathing when listening intently to some pieee of musie or to some patriotic orator. One has seen a whole eompany draw a long breath of relief after an exciting seene on the stage. The holding of the breath and the long after-breath show how very strongly our aetivity of breathing is affceted by the impressions that come in at ears and eyes.

As for digestion, we all know that excitement is very far from eondueive to the enjoyment of healthy life; and recent researches earried out with the aid of the Röntgen rays on the movements of the stomach of a eat during digestion showed that these movements stopped with surprising promptness and invariability whenever the animal was disturbed by any external impression.

All of these facts serve to call attention to activitics 
accompanying impressions, and they ought to enlarge our common view of what activity means. When one sits still and listens, he may be very active in some one of these internal systems, even though he presents to himself and to the world at large a placid and unruffled exterior.

It remains to mention another group of activities which are not internal, but commonly escape attention because they are so constant. Did you ever stop to consider that cach one of us is constantly active so long as he sits up and loolds up his head? One has only to watch a nodding, drowsy man to rcalize how much muscular energy is involved in our ordinary sitting up. The muscles of the ncck are always in a state of tension during waking hours, and thcir activity must not be omitted when we are making up a list of our ordinary bodily responses to impressions. For is not hanging the head a proverbial expression for shame? Do we not recognize the man of buoyant spirit by the proud carriage and the head thrown back? Do we not notice the straighter walk of the soldier when the thrilling martial music is ringing in his ears? Indeed, one can notice on every hand the close relation bctween the way one carries himself and the way one looks at the world about him and sees in its impressions hope and promise or envy and enmity. One's bodily activity can not be described without full recognition of these forms of muscular activity which appear in our attitudes. They are not forms of rapid movement, and that is why they do not impress us very strikingly. They show all the better the fundamental distinction between the activity and what we ordinarily mean when we use the 
term movement. The body is always active, internally and externally, whether its parts are noticcably moving or not.

This distinction between activity and movement is significant for the teacher. Do you think that the boy who sits still in his seat at school is not active just because he is not moving? Watch him a little more closely and you will sec that the true description of what he is doing involves a good deal of attention to forms of activity that are no less real because they are not forms of external movement. That boy would, if he did the natural thing, get up out of his seat and come up to you, as, indecd, he often starts to do when he forgets. He would naturally start and go to his neighbor who has something interesting under his desk, if it were not for the law of the school. He would jump up and look out of the window at the slightest provocation. The reason why he does not do this is that a kindly Providence has furnished him with two sets of muscles, onc which would fain do the forbidden thing, and the other set to hold back these unruly members. And when the boy wants to look out of the window, but seeing the threatening look of the teacher, holds himself in the seat, he sits still by sheer force of muscular activity. His warring activities are not as obvious to the cye as they would be if he started up and then sat down again in a hurry, but he is in reality getting up and sitting down at the same instant, so that what may look to the superficial observer like sitting still is in reality doing much hard work.

You have felt like sneezing or coughing, have you not, when you were obliged to go through the ex- 
cruciating expcricnce of kceping still? You have had a tickling scnsation on the end of your nose at a time when you did not dare, out of respect to your social cnvironment, move your hand up to that irritating organ? How did you manage in these cascs to sit still? Was it not through an effort, and was that cffort any the less real because it did not involve actual movement? Such an experience ought to help you to understand why it is that a boy has such difficulty in keeping still; for the sights and sounds out of doors which stir our torpid grown-up blood all too little, are to lim the most attractive objects in the universe, and the thought of running about the room is as irresistible to him as is the most inviting allurement to our adult ambitions.

But we must draw this discussion to a close without cntering into any of the applications of this principle that nental activity is always paralleled by bodily activity. It is to be hoped, lowever, that the impression begins to grow in your minds that we are very active beings, and that our usual prejudice against activity in the school is not altogether justified. The activities which we arc exhibiting in larger measure than we usually rcalizc, are of great importance to the tcacher in his study of himself and in his study of his pupil. The traditional notion that the school is a place in which impressions are merely to be poured into the mind has laad its day. We are beginning to enter upon a new cra with new educational ideals, and it will be well for us to get out our old ideals about the nature of mental life and give them a thorough renovating. The fact is that most of our notions about bodily activity are due to the fact that we have overlooked the inner activ- 
ities, and that we have overlooked thosc constant cxternal activities which do not result in actual and obvious movements. But these large groups of unnoticed activities are very closely related to our impressions. A given impression results in its own appropriate activity, and that activity is just as much a part of the bodily condition of the experience and of its interprctation as is the process in the eye or ear which we call a sensory excitation.

We shall take up next some discussion of the general principles upon which we are reconstructing our educational ideals. The work of this chapter has bcen largely negative. We have attempted to call attention to the fact that the teacher's professional ideals frequently rise and get themsclves established on wholly inadcquate grounds. The teacher then forgets where the ideal really came from, and holds to the unjustified ideal with all the grcater tenacity because its grounds are lost from view. What we necd in our study as teachers, is to become conscious of our idcals, to think of their grounds, and to rccast many a false belief in vicw of fuller and bettcr knowledge. 


\section{CHAPTER IV}

\section{THE NEW IDEALS OF DEVELOPMENT}

The last ehapter closed rather abruptly with a negative conclusion. In that diseussion we were showing how unfounded is our ordinary notion that mental life can be understood without attention to aceompanying bodily aetivities. There was a very large positive prineiple involved in that conelusion, the prineiple that every mental state has its parallel bodily expression, but we did not there attempt to work out that positive principle with all its pedagogical eorollaries.

The negative conelusions of our earlier diseussions were, however, merely preparatory to the positive, eonstruetive treatment of edueational ideals. Certainly there could be no justifieation for mere negations in a series of diseussions of this sort. Indeed, there is no justifieation for mere negation in the thought of any teaeher. We should never stop working on our ideals until we have something positive. See to it that you never cultivate that chronic state of doubt whieh makes it impossible for you to belicve in the validity of any ideal. You will never have peaee of mind in your teaching, you will never overeome the fretful wear and tear of seeking after petty deviees, until you 
have found out some broad positive prineiples which can be relied upon to guide your work.

Fortunately there are many positive ideals and positive principles with which to replaee old and wornout prejudices. These newer ideals are being offered to the teachers on many sides. Sometimes the new principle is only half formulated. Sometimes the enthusiastic advocate is disposed to overemphasize the value of this or that new educational doctrine. Indeed, there is much sinning by way of omission and commission; but through all the error and the misguided enthusiasm, one can see the outlines of a few of the great fundamental principles which promise to furnish our educational practise with a firmer and broader basis than has ever been known before.

One of these general principles is the principle of expression, with the negative side of which we closed our last chapter. No one has given this principle a clearer statement than has Professor James in that almirable book of his, Talks to Teachers. He defines education $^{1}$ as "The organization of acquired habits of conduct and tendencies to behavior." Such a definition throws the whole weight of attention in teaching, not on the impression which is given to the child, but on the expression which is to result from the impression. In the chapter following the one from which we just quoted, Professor James confirms the position taken in his definition of education with these strong words: ${ }^{2}$ "An impression which simply flows in at the pupil's eyes or ears, and in no way modifies his active life, is an 
impression gone to waste .... It leaves no fruits behind it in the way of capacity acquired. . . Its motor consequences are what clinch it. Some effect due to it in the way of an activity must return to the mind in the form of the sensation of having acted, and connect itself with the impression. The most durable impressions are those on account of which we speak or act, or else are inwardly convulsed." Such an ideal as this which Professor James gives us is certainly full of positive suggestions for the class-room teacher.

One might seek out other examples of strong positive contributions to educational thought, but we shall not content ourselves with a mere review of these principles as they are given to us by our leading thinkers. We are fortunate in being able to seek the same source of inspiration which these great leaders have sought, for the whole thought of our times, not only in education, but in every sphere of natural science and sociology and psychology, is dominated and controlled by the one great principle, the principle of development.

Within the last half century we have secn this idea of development rise and spread over every domain of human thought. The geologist seeks to know the development of our planet. The astronomer inquires boldly into the sccrets of the great cosmic devclopment that brought forth our sun and our sister worlds. On the other hand, delving down into the infinitely small, the biologist seeks to know the development of the minutest living cell. Even the student of human life in any and all of its phases, has adopted the same point of view, and whether he be historian, or economist, or 
psychologist, his chief problem is to trace the course of human development.

I need not tell you that in the educational world this same idea of development is everywhere being recognized. The development of the child, the development of our school organization, the development of the curriculum-all these are common subjects of investigation. Has not our own subject up to this time been the subject of the development of the teacher's ideals? And so we are introducing no strange question when we ask what is this general idea of development. What is its value to the teacher, and how can we get some help from it in our school work? If it is true that Professor James in his Talks to Teachers is only working out this idea; if it is true that Professor Dewey is seeking to realize the same ideal in his experiments; if it is true that President Hall has to thank his grasp of the same idea for what of value there is in his writings-if all these men come back to the one broad idea of development as their starting-point, then, certainly, it is time that the individual teacher should turn with all despatch to a study of this fundamental idea.

True, this is no easy task which I have proposed to you, for all the recent writings in the sciences and in education have been trying to work out the details of this idea. The story is told of Huxley, the English scientist, that on one occasion a narrow-minded opponent wrote, demanding that Huxley send him a brief summary of all the arguments for evolution, in order that this same opponent might refute them. Huxley replied, advising his correspondent to take a complete course in the science of comparative anatomy, 


\section{GENETIC PSYCHOLOGY FOR TEACHEISS}

in whieh science Huxley assured him he would find many of the reasons in favor of evolution. And, perhaps, some eaptious critic will be disposed to set aside our suggestion that the-individual teacher acquaint himself or herself with the meaning of this fundamental idea of development on the ground that sueh an aequaintanee would involve a study of all reeent scienee. But I think we ean meet our eritic by admitting frankly the truth which there is in his remark. Certainly the individual teacher can not read all the modern literature on development. On the other hand, no teaeher should fail to read some of this literature, enough at least to grasp the meaning of the idea. If eaeh teacher will get the broad outlines of the idea, he or she may leave it to the speeialists to work out the details in this direetion and in that, devoting himself or herself to the narrow and yet thoroughly produetive task of working out the details of the idea in the elass-room.

The edueational world has need of a vast army of investigators to settle some of the unsettled questions about mental development. The various forms of development of the mind in the eourse of its learning to read, or write, or eount, are phases of development with which no one is fully aequainted. These are phases of development that no one has any better opportunity to investigate than the individual teaeher. Iset us not give up this task beeause we ean not solve it before we begin our work. Let us, rather, boldly enter into the investigation, first getting something of the inspiration and guidanee that is to be derived from a survey of the general prineiple of development as it has been formulated by the leaders in seience up to this time. 
The idea of development was first worked out in the science of biology. The other sciences, such as sociology and psychology, liave borrowed a great deal from the earlier studies of biology. Perhaps we shall do well to go back to the biological formulation of the principle of development as the basis for our present discussion.

The biological notion of development may be defined by the use of three phrases. The first of these is the phrase, individual variation, the second is selection, and the third is hereditary transmission. The best way in which to get at the meaning of these three phrases will be to take a concrete illustration.

There is a little mouse-like animal which lives in our fields and burrows under the sod for earthworms. It is called a ground nole, and has broad shovel-shaped forefeet by means of which it does its digging. This same little animal has very small, weak eyes. Indeed, at times the eyes are not only much reduced in size, but are covered with a layer of skin so that they are useless for vision. The mole spends most of its time underground, and digs out intricate passages for itself in its search for food.

We know something of the history of the mole species through our study of embryology, for the embryo repeats in a large measure the typical stages of the development of the species. Our knowledge of the history of the mole species teaches us that generations and generations ago, the ancestors of the present moles were of a different type. They were small, mouse-like creatures which devoured insects and worms, but lived above the ground and had strong eyes and no broad 
digging forefeet. In other words, the first moles were not like the present moles either in habits or in structure.

Let us carry ourselves back in imagination to the early moles that lived above ground and had strong eyes and slender toes. We know what happened with a good deal of detail, for the biologist has seen similar facts over and over again in our modern world. There was a day on which some mole in foraging for food got hold of an earthworm. It turned out to be good food, and the fortunate mole began to look for more. Finally, it found that it could get earthworms best by doing a little digging. A good many animals have learned to dig to some extent; think of the fowls. But this digging meant a great change in the mole. It began to be interested in a wholly new kind of life. The earthworms had never been the prey of animals of this kind before, and they were very plenty. The whole mole family began to dig for worms.

By and by there was born in the family a little mole which had broader forefeet than moles had been used to having. Whether this was due to the fact that the parents of Broadfoot had been getting stronger and broader feet by digging, or whether it was a mere accident, is hard to decide. The fact is that the little mole arrived with a broader foot. This individual variation, as the biologists call. it, this deviation from the usual structure of the family, gave Broadfoot a great advantage. He could dig faster and could get more worms with his improved shovel than could any of his family. He even grew bold and went clear under the ground, and in that way he escaped the enemies he 
would have met above ground, and had an easier time under ground where there was less competition. The experiment which nature had tried of giving one little mole broad feet was a great success. The advantages which Broadfoot enjoyed made him live longer, and he had a larger family and supported them better, so that ultimately broad feet came to be the most common form among moles, and the moles with slender feet had a harder and harder time, and ultimately died out. This preservation of the stronger type and decline of the weaker type is what the biologist calls natural selection. Natural selection is no premeditated choice on any one's part; it is, to use another current phrase, merely the survival of the fittest. And the fittest who survive, transmit their strong characteristics to their young through hereditary transmission. Some of the young in any family get more and some get less of the desirable characteristics. Thus, we have a new series of individual variations and a new series of selections of the fittest, and a new series of transmissions.

The broad feet of the mole have thus, through long generations, been gradually improved until they have reached their present form. In the meantime let us not forget to include the eyes in our study of development. The first moles probably had a good deal of inconvenience under the ground with sand which kept getting into their eyes. By variation the eyes of some moles turned out to be very small and weak-all the better for the underground burrowing. In fact this seeming weakness was a positive advantage. What a fortunate mole among moles must have been the one born with a layer of skin completely corering the eyes! 
Development is thus a progressive fitting of a spceies more and more fully to its environment. Whatever is desirable in the strueture of any member of the species is fostered and improved. Whatever is undesirable is cut off. But desirable and undesirable in this ease are relative terms. Desirable means helpful in the given environment. Thus we should speak of eharacteristies as being, not absolutely good or absolutely bad, but as suited or unsuited to the environment.

The prineiple of adaptation was foreefully stated by Professor Minot in his address as president of the American Assoeiation for the Advaneement of Seienee. His statement was as follows: "Vital functions have a purpose. The purpose is always the maintenanee of the individual or of the raee in its environment. The entire evolution of plants and animals is essentially the evolution of the means of adjustment of the organism to external eonditions." And after making this general statement, Professor Minot applies the prineiple to human progress, so that there may be no doubt as to the man's share in this progressive adaptation to environment. He says: "In practical life it is eonvenient to distinguish the works of nature from the works of man, the 'natural' from the 'artifieial.' The biologist, on the contrary, must never allow himself to forget that man is a part of nature, and that all his works are natural works. This is espeeially important for the present diseussion, for otherwise we are likcly to forget aiso that man is as eompletely subjeet to the necessity of adjustment to external reality as any other organism. From the biological standpoint all the work of agriculture, of manufactures, of commerce and of 
government is a part of the work of consciousness to secure the needed adjustments." 1

It should be noticed in this connection that development for adaptation may reach a stage of relative conpletion. That is, progress in adaptation may go so far that an animal is sufficiently well adapted to the particular environment in which he lives, and then change either stops entirely or goes forward only very slowly. Thus, the forefeet of the ground mole represent what is, in all probabilities a completed adaptation. If the forefeet should by variation appear in any given mole wider than the average, this would be no advantage, for an increase above the average width of the digging foot would require an increase in muscular strength in order to manipulate the wider foot. And this increase in strength would require in turn a larger body, and a larger body would mean that the mole would have to make a larger passage through the ground. These larger passages would require more digging than the smaller mole has to do with the average forefoot, and this requirement of more digging would neutralize the advantage of the broader forefoot. There is thus a certain equilibrium where the animal is better off than it would be throngh further increase in the size of its organs. Many animals which have been long in a given environment have reached such a state of relatively complete adaptation.

We turn now from the kind of development which we have been discussing, the structural development, as we may call it, to consider another phase of develop-

${ }^{1}$ Science, July 4, 1902, pp. 9, 10. 
ment. There is a social development as well as a structural development. Every species of animals develops certain common habits of life, and these are transmitted to the young of the species through the example set by the older niembers. The social tradition is very strong in certain species. Think, for example, of a little ant or a little bee coming into their respective communities. The military order and division of labor in an ant-hill or in a bee-hive, are matters that could not be transmitted to the young of the species in the form of bodily structures, but they are a part of the lesson of living which the species has learned in its long struggle for existence. The young addition to the community must learn to fit into the cooperative life of the community. This process of learning what are the rules of community life, will be a great benefit to the individual, and he will gain from it lessons which he never could have worked out for himself if he had not seen the whole community in action. The individual, therefore, gets, through imitation, a kind of social inheritance which is different from the structural inheritance with which we are well acquainted. Imitation has accordingly been called the means of social heredity.

Social heredity is one of the most important phases of human development. To be sure, we are in very large measure what we are as individuals because of a long process of structural development in our race. Think of our hands and feet, for example, as illustrations of structural adaptation. In the other higher animals the fore extremities and hind extremities are much alike, but with us the legs are long, strong, supporting organs, ending in feet which are very advan- 
tageously supplied with broad flat walking surfaces and with short and little developed digits. The arms are light and muscular, with free joints, and they carry hands which have long flexible digits adapted to the most delicate kinds of manipulation. Surely this differentiation in the structure of our hands and feet shows a very high degree of adaptation of the purely physical or structural type. But think of the immensely higher form of development which comes in the life of every one through social heredity. Think, for example, of the student of art, supplied with hands through physical development, but learning the use of those hands only through the careful training of some master. This master's training is a part of the student's social inheritance. Or think of the athlete supplied with legs and feet through structural inheritance, but learning the use of these organs under the social stimulus of competitive races. Our social training is, after all, our highest inheritance.

Before we turn to the direct application of all these general terms which we have been defining, to our own special problem of school training, it will be well for us to recognize the fact that variation, and selection, and adaptation have a narrower meaning and may be applied to strictly individual life. Not only does the individual as a member of a species profit by advantageous variations, but the individual develops in the course of his own life through a similar series of discoveries of new adjustments. Thus, take the case of a man who has always done some act in a given way, until suddenly he finds by a chance variation or by a carefully premeditated rariation in his mode of action, that some other 


\section{GENETIC PSYCHOLOGY FOR TEACHERS}

way is better. This is a personal variation. The savage who first discovered that arrows would fly straighter if feathers were added to the bare shaft, eontributed an important faet to general knowledge through individual variation.

The period in life when variations are the predominating faets is the period of ehildhood. Did you ever notiee that children learn to ride a bieyele sooner than old people, and are very much freer in their aetions after they have learned? Their greater faeility in learning is due to the fact that thcy begin to learn at a period when all their movements are mueh more variable than they will be in later life. Consequently, ehildren diseover the right movement to make in balaneing themselves on a bieyele sooner than adults, bccause they naturally make more different kinds of movements. They have, to use the technieal terms, a greater series of variations in action from whieh the best and most adaptive movement may be scleeted.

After this gencral discussion of the nature of development, let us turn to a eonsideration of some of the modifications whieh the acceptance of this general idca has wrought in our pedagogieal ideals. Take first of all the question which Franke discussed so seriously, the question of whether the ehild is by nature good or bad. You remember Franke's answer. He said the child is low and earthy in his nature. His play is an exhibition of the evil in him, and so on through the whole list of ehildish eharaeteristies. This view was perhaps more than usually emphasized by Franke and his followers, but it represents fairly well the generally aeeepted notion about the child even less than two 
centuries ago. Rigor and constant suppression of the childish nature werc the accepted practises of the school, so long as this view prevailed.

Suddenly, in the midst of all this rigor of practise and strenuousncss of ideal, there came the teacher of a new educational gospel. That new gospel was given to the world by Rousseau in his book on the education of Émile. If Franke and others had thought the child's nature evil, hear the opening scntence of Rousscau's book: "Everything is good as it comes from the hands of the Author of Nature, but everything degenerates in the hands of man." 1 And then if you will follow the later argument of the book, you will find Rousseau carrying out the idea that the child is good and necds only to be allowed to grow up in a perfectly natural way. We are warned against the harmful influences of social life, against the artificial practises of the schools. Back to nature! Back to the primitive forms of life! These were the doctrines of Rousseau and his school.

With this fundamental disagreement between those who believe the child to be good, and those who believe the child to be bad by nature, what is the individual teacher to accept as the true idcal? I confess I do not wonder that teachers feel confused. Take, for example, the modern form of this same dispute about the goodness or badness of the child's nature. It centers around that word of which we hear so much from the Herbartians, the word interest. There are those who tcll us that the child's native interests are the safest guides to lead us in the tasks of sclecting and arranging educa-

'Payne's translation, p. 1. 
tional materials. We have heard edueational writers and speakers enforce this argument in favor of natural tastes and interests by such statements as this: "Physieians are eoming to agree that in cases of convaleseenee from disease, when there are no known rules to guide the patient's diet, it is safe and expedient to follow the patient's own wishes." "Henee," runs the argument, "when we do not know what is the best course to pursue in directing the development of the eliild, it is safe to follow the ehild's own interests."

Opposed to all this unqualified aeeptanee of the child's interests, as guides of our educational practise, stands our knowledge that ehildren's interests are very transient and often very trivial. Some would say that it is obviously best at times to make the ehildren do the hard and uninteresting things. I am not sure that the highest wisdom does not favor that strenuous form of training whieh one of our Chieago educators is said to have adopted. He is so opposed to the doctrine of natural interests that he gives his ehildren eaeh day, at a certain hour by the eloek, a short course in bodily ehastisement as a supposedly helpful, though probably uninteresting, preparation for the hard, uneompromising duties of life.

So the dispute goes on, and there seems to be little light on the difficult question of whether the ehild is good or bad. As for most of us, we work out a sort of average between the two extreme views. We applaud the eulogizing of the child nature in public, and we reserve the right to think a great deal in private about the ehild's innate wiekedness. We urge lenieney on our fellow teachers in view of our confidenee that the 
child is by nature tending toward better things; and yet for ourselves we sometimes mourn that the day of the rod as the symbol of pedagogical authority is rapidly passing. In short, we have most of us patched up a compromise between Franke and Rousseau, and believe in both. The child is bad, yes, that is too true! The child is good by nature, yes, that is the saving clause in our creed!

The gratifying fact about the doctrine of development is that it makes it possible to continue in our average belief that the child is neither wholly good nor wholly bad, and at the same time it places this average belief of ours on a firm rational foundation and explains it and illuminates it in the most complete fashion.

The doctrine of development says of the child, here is an immature being. He is not adapted to the environment in which he has to live. He does all sorts of things that would injure him, and fails to do a great many things that are quite essential to a happy and successful life in this environment. In short, considered with reference to the immediate present, this child is about as poorly adapted to life as any one easily could be. But, continues the doctrine of development, this is, after all, not so bad as it might be, for the child has certain redeeming characteristics. He has the possibilities of variations and adjustments in a much higher degree than we older people have. Where we fail to fit our environments, we are generally so fixed in our habits that we can not easily change. If we are unadapted now, we continue unadapted to the end. The child, on the other hand, has the largest possibilities of fitting himself to his environment. In this he is much 
better off than any mature person in the world. If the child's lack of adaptation is a bad characteristic, then certainly this adaptability is one of his most hopeful characteristics, and quite compensates for his lack of present adaptation.

Do you not see where the fault has been in earlier discussions of this subject? Teachers have applied adult standards to the child's life. According to adult standards, lack of adaptation is an evil. We must come to recognize the fact that in judging the child's nature no such standard will apply.

See how this new view of the child as a developing individual is modifying our notion of punishment. We do not punish a child now because we wish to meet out to him vengeance for his infraction of law. We punish a child these days only when we deem pain helpful to him as an aid toward his more complete adaptation. The law of the school has a deeper meaning to us. It is a rule which if obeyed will help the child to pass from an unadapted state to one of adaptation. If the rule is not strong enough to lead the child pleasantly and without compulsion in the right direction, stronger measures must be adopted. Teachers of to-day who understand the real meaning of punishment do not get angry at children. I think the greatest advance in school discipline that we have to record in recent generations is the advance which has been made in the teacher's attitude toward the child. To-day we look upon the child's mistakes and failures as phases of the process of development. We correct these shortcomings as a part of our general duty of supervising development. 
While we are on this subject of punishment as one phase of the process of education, it is interesting to note that we who teach in the schools are not the only ones who have come to take a broader vicw of the meaning of the terms good and bad, because of this increased insight into the nature of human development. Go to any one of the well-conducted penitentiaries of the land and you will see that there too, men are treated, not as if confinement were society's revenge, but as if confinement were society's means of education. There are a great many men to-day who are studying the criminal, and they are very generally of the opinion that the typical criminal is a man whose development has been arrested in some way or other. Give this undeveloped man an opportunity to get some further training and see if we can not in that way adapt him to life in the community. That is the way in which those who study the criminal are arguing, and their principle is exactly the same, if you will only recognize it, as that which we are adopting under very much happier conditions in our schools.

You can see, I think, that the far-sighted application of this principle of punishment as a means to education does not forbid the use of pain. We are not to make the developing process at all stages one of easy concession to individual preferences. The fact is that every now and then the individual needs a sharp turn in development. Even nature, to which appeal is so often made by those who would have the child's life one unbroken day of sunshine-even nature uses pain as a means of development. The unpleasant consequences from any form of overindulgence are nature's punish- 
ments. They are not nature's revenges, but rather her lessons to guide us in the future.

Another change in our educational views which has resulted from our new insight into the nature of development is that we do not regard the child's early unsuccessful efforts in any line of thought or action as culpable mistakes. When our fathers and mothers went to school, the teacher used to blame the boys and girls for not being able to write well or pronounce well, or for not being able to do this or the other thing correctly. The teacher merely heard lessons; sat as a sort of judge of the perfection of the child's adaptation, and measured out reward or punishment according as the child was successful or unsuccessful. To-day we think of the child's errors, not as culpable offenses, but as indications of a need of fuller development. We do not demand of the immature child that he shall fulfil the same requirements as those which we impose on adults. In short, we consider perfection to be a relative term, to be applied with a clear rccognition of the stage of individual development.

The adoption of different standards of judgment for different levels of development is a phase of our application of the new ideals of development to which we have already made frequent references in earlier chapters. We pointed out, you will recall, in our first discussion of visual perception, that the same image falling on two different eyes will be differently interpreted. These different interpretations, even when they are what we call illusions, are not to be classified as right and wrong, but rather as more or less fully developed. And so through our whole discussion of the teacher's 
life, we have been seeing again and again the same general principle illustrated, the principle that different stages of mental life are different in character and require different standards of judgment.

This difference betwcen different levels of devclopment is sometimes overlooked because we see the same person passing through the differcnt stages of progress. We see the same boy, for example, taking work in arithmetic and then in algcbra, and we somehow think of the boy as just getting more and more mathematics. In other words, we overlook the fact that the general word mathematics covers a number of different modes of thought, and that the word boy covers a great many different levels of development. Sometimes we have a striking illustration which calls our attention emphatically to the fact that the boy studying arithmetic is quite a different grade of boy from the same boy when he has, later in life, grasped the mode of thought appropriate to algebra.

Let me give you an illustration which brings out the difference betwcen the arithmetical stage of development and the algebraical stage. Some years ago some students of education and of mental life discovered in a country district in Indiana one of those, interesting characters known as a mathematical prodigy. This boy could add great columns of figures with astounding rapidity. He had a multiplication table that ran up to 150. He knew all the short methods of calculation given in the books on rapid methods, and he had invented other rapid methods unknown to the makers of books. In short, he had more arithmetic in his head and at his ready disposal than any of the skiliful 


\section{GENETIC PSYCHOLOGY FOR TEACHERS}

mathematicians in the land. They took this boy from lis home to the State University and tried to train him so that he might find a higher use for his mathematical bent. But just at this point they discovered the fact in which we are now interested. They found that this boy had so much arithmetic that he could not, or would not, learn any algebra. In other words, he had developed all of his powers in one way, and that, too, at a relatively low level, and now the next step upward was impossible to him. Algebra was not according to his mode of thought.

Nothing could show more clearly than this example of the arithmetical prodigy the fact that modes of thought at one level of development are not the same as modes of thought at higher levels. The most obvious warning which comes from the case cited in our illustration is the warning not to let children stay too long at one level of development. But deeper than this warning, the student can see in the cxample a most admirable illustration of the broad principle that different stages of mental development are essentially different, and require different standards of judgment.

What is perhaps the clearest recognition of this principle, appears in the recent scientific studies of the mental lives of animals. Animals have often been credited with marvelous mental powers. Who has not heard that crows and cats can count? Who does not wonder at the geometrical knowledge of the bee which builds its cell in the perfect hexagonal form, and so on through the whole list of animal achicvements? And now we are coming to recognize more and more clearly that in none of these performances of the animals is 
there any justification for assuming the existence of marvelous mental powers.

The crow sees five men go into a hut and four come out, and he does not allow himself to fall into the trap and come into dangerous proximity to the one remaining man. But that does not show that the crow counted the men who went in and the men who came out. It might show ability to count if mental life were all at one level, and that the level of mature counting consciousness at which we live. But even you and I have methods of dealing with number relations without resorting to our usual method, which is the highly developed method of counting. Did you never go to the store and make a number of purchases and then start home with a haunting feeling that you have left something unpurchased? You did not count, that is obvious, for if you had, you would have been sure whether you had left something undone or not. Can you explain that feeling? Certainly the feeling is not the result of counting.

Or take an illustration from some of the experiments which the psychologists try in their laboratories. Sit down at your table and with a pencil make a series of taps. Do not count, but just make a short series of about eight to twelve taps. Now pause for a moment, and make another series of exactly the same length. You can do it with a certainty which will surprise you if you have never tried it before, and all this without counting.

The fact is, we have in mature mental life a good many different ways of dealing with number relations - some higher and some lower. The highest way of 
dealing with these relations is that of counting; one of the lower ways is that which we have just described of grouping objects without counting. The crow probably does not count, he recognizes groups.

Or take other relations than the number relation. Take some of the animal instincts that make animals appear to have such great foresight. Take the persistent and highly commendable devotion of the setting hen to her eggs. We shall be deceived if we attribute all this to any clear-headed maternal foresight or prophetic imagination. Her action is rather, as Professor James says, to be attributed merely to a blind feeling uppermost in her consciousness that those eggs are the never-too-much-to-be-sat-upon things.

Or another illustration given us by the naturalist Wallace, may be used to illustrate how animals come to deal easily with distances and with falling bodies. Their knowledge of these subjects is not of the high type of the scientist who lays his yard-stick upon the distances and times the falling body with his delicate chronometer. When you hear this illustration repeated you should think of that blind form of feeling for distance which the ball-player has when he pitches a curved ball or bats at one. You should think of the way in which a billiard-player knows his angles of rebound without the higher abstract forms of measurement. The illustration, which I wish to borrow from Wallace, is a description of the skill in flight exhibited by certain sea-gulls in the Southern seas. Far from land, and quite unable to light in order to devour the fish which are their prey, these gulls develop the ability to feed in mid-air. After catching a fish, one of these 
birds soars far above the surface of the water and there it cuts the body of its prey in two with its sharp beak, and lets one part fall while it swallows the other part. Then, with incredible rapidity, the bird swoops downward, overtaking the falling part before it reaches the water, and, recapturing it, rises again and repeats the process until finally it has devoured all of the fish. Such activities as these are more accurately adjusted to the relations of space and gravity than any of which the child or even the most highly trained adult is capable. And yet we do not think of the bird as higher in its intelligence than man. The fact is, we recognize the general principle that the level of mental development attained by the bird, and hence its whole mode of mental action, is different from that exhibited in the highest processes of adult life.

This principle of mental development is coming to be very fully accepted among scientific students of animal life. It is also coming to be recognized more and more by teachers as they study the levels of mental development at which they find children. Children, too, have a certain recognition of number. Is it the same as adult recognition of number? Evidently it is not, for we find children quite unable to manage some of the relations with which we deal easily. But is this the only difference between children and ourselves, that we can manipulate more relations than the children can? Is the difference merely one of the number of processes with which we are familiar? Do children and adults think in the same way about even those relations with which they both deal? The answer to this question we are coming to understand in the light of our principle 
of development. Even when dealing with the same relation, ehildren's modes of thought are not like ours. They are at a different level of development, and that different level of development means a different mode of thought.

Thus, when the ehild first learns addition, the proeess does not have the same meaning for him as it does for the adult who knows the relation of addition to the higher process of multiplieation. And when the ehild learns multiplication, the proeess does not have the same signifieanee for him as it does for one who understands the use of logarithms. With each step in advance one sees richer and richer meanings in the proeesses which he half grasped in ehildhood. The man reads Robinson Crusoe or Gulliver's Travels and sees, not only the story which interested the boy, but he sees the literary art and the deeper satire on soeial life. His view is, as we say, broader and fuller. This is what we expeet of a developing individual. We apply different standards of judgment to different stages of mental life, and it is well that we should. The duty of the teaeher is to recognize this as a sound principle of edueational praetise.

The general principle of differenees in mental proeesses at different stages of development, opens up a whole series of questions for the teacher to investigate. How does the ehild deal with number relations, how does he read and write? The details of mental development call for investigation, for we understand as yet very little of the different stages through which children pass. Even memory of our experienees, as we have already pointed out, helps us but little in 
understanding the details of development, for our own earlier experiences did not consist in attention to the processes of development.

This leads us to a consideration of the fact that the child, though he is all the time developing, is wholly without knowledge of his own process of development. Take, for example, the child at play. We are coming to recognize the great importance of play for individual development. The child has weak muscles and organs of sense which have never had their full range of experience. Nature does not send such an untrained child into the serious struggle of real life, but lets him spend a few years in a sort of sham struggle. This sham struggle the child takes in all seriousness, and enters into it with all enthusiasm-for him it is real life, though we call it his play. The child sees only the things with which he plays. He does not look beyond the play and see the development for the future which he is getting. He just romps, and has a good time. There is nothing premeditated or reasoned out in his conduct. He is developing in what may be called the natural or wholly non-rational way.

In calling the child's development non-rational we must make sure that the word non-rational is not misunderstood. Non-rational does not mean irrational or contrary to reason. The child may grow into an adult, and, looking back on his development, he will see how the struggles through which he has passed all contributed to his better adaptation. He will then recognize the reason for this or that impulse implanted in him by nature. He will see, for example, why nature gives to every child a play impulse. He will also come 


\section{GENETIC PSYCHOLOGY FOR TEACHERS}

to understand why it was advantageous that this or that variation which he exhibited as a child should be checked before it became a burdensome habit. In other words, he will see as an adult, beyond the immediate facts which engaged his attention as a child. $\mathrm{He}$ will see beyond mere play, and discover that play is in reality a process of development; beyond the painful experience he will later recognize nature's helpful lesson. In short, he will see how fully in accord with the principles of his reason it has all been. His development will thus appear as rational, though he did not know it before, and though he did not plan it-though it was wholly non-rational when it was actually taking place.

Again, when we say that the child's development is unpremeditated and non-rational we conceive ourselves as standing in the child's position. From the teacher's point of view the child's development should not be non-rational. The teacher should know why play is good for the child. The teacher should always be considering the proccss of development rather than the immcdiate facts of the child's expericnce. The teacher's place in the development of the child might be dcfined by saying that the teacher is a rationalizing factor-a kind of higher intelligence furnished the child to aid him in passing through the dangerous non-rational period of childhood. As the child takes step after step thoughtlessly and unknowingly, it is the duty of the teacher to stand by him and to prepare the way for cach of these steps of development, so that nature may bc supplemented in bringing the child safely and well to maturity.

Do we as teachers succeed in this rationalizing of the 
child's development? Let us ask this question specifically, with reference to one of the subjects that we shall take up later. Do we as teachers know how to develop the writing habit in children any more rationally than they themselves? Is not the writing lesson too often a blind struggle in which teacher and pupil unite in a sort of try, try again form of procedure, which never realizes whither it is leading? Is it rational to leave our children to work out their own educational salvations with a mere engraved copy to guide them? The copy merely shows them the end to be attained. Between their undeveloped efforts and that goal lie leagues after leagues of development. How shall they best find their way along that weary road? Who among us is ready to answer clearly? Who among us knows the steps by which fingers and arm and hand grow more and more responsive to the demands of brain and eye? Who among us is prepared to do his full duty until all these stages of development have become parts of his rationalized knowledge?

Such questions as these are questions that every teacher should face. They are the questions which arise the moment one realizes that the teacher stands by the child to rationalize the child's non-rational development.

Another line of thought, which we may take up briefly, enforces very greatly the principle that the child's development is non-rational. It is the line of thought which grows out of a consideration of the facts of imitation. Modern science has given a good deal of attention to imitation. It is one of the means of transmitting habits from the older generation to the 
younger. It is a channel of what we called a little while ago social inheritance. The infant sees its mother smile, and there spreads over the infant's face a reflected smile. Do you suppose that the infant realizes that this is one of the means by which his devclopment in the social habits of expression is being accomplished? Of course not. The infant just imitates in a wholly unthinking, non-rational way, and the development goes on as nature has prescribed.

We can understand this sort of unthinking imitation when we catch ourselves imitating a yawn that we saw a moment ago. Or let some member of our social circle set some fashion, cither of conduct or of dress, how meekly we all follow! Fashion is the blindest, most non-rational thing in the world, and it owes its power to the trait of human nature which we are discussing, namely, the tendency to imitate.

The teacher does not need to be told that children are great imitators. For wccks after a Buffalo Bill show has been in town the boys will be lassoing posts, and small domestic animals, if not, indecd, passers-by. Let a company of soldiers pass through a city, and the boys will do nothing but think of military affairs during the next month. The girls, too, have their milder imitations, as one can see when some little six-year-old daintily prevents her perfectly safe skirts from getting into the dust of the crossing, by holding them as her seniors do theirs. And the teacher who recognizes this tendency toward imitation in children, recognizes also that it is wholly non-rational. The child does not sit in judgment on the habits of his elders. He simply follows blindly whatever they do. Education would be 
very far advanced if it did nothing but select and set before the children good examples for imitation. The teacher certainly can not afford to overlook the fact that blind non-rational imitation on the part of the child, places on the teacher a very heavy burden of responsibility for the setting of clcar-sighted, rational examples to be imitated.

There is a final lesson whieh must be added to this discussion of the non-rational eharaeter of the clitd's development. The child should not always remain non-rational in regard to his own development. Hc should gradually be brought to the stage where he can become his own rational guide, his own teacher. 'The educator who does not sce to it that children are made independent of him, has not done his whole duty. And this process of rendering the child independent and rational is not a task to be undertaken suddenly at the end of school life. Wc used to think of graduation day as the commencement of independent self-guided eonduct. We are coming morc and more to sec that all along the eourse of the sehool life the lessons of dcvclopment may be learned in two ways. First, nonrationally. That is nature's first method. And then as soon as some experience has been gained by naturc's first method, this experienee should be turned to account in the development of a higher stage of mental life, and at that higher stage it will be possible to advance not mcrely non-rationally, not merely by blind struggling, but also by self-eonscious struggling, whieh is self-dirceted, rational conduet.

There are other lessons that come to the teacher from the study of the principles of development. Some 


\section{GENETIC PSYCHOLOGY FOR TEACHERS}

of these are of such importance that we shall be justified in takìng up another ehapter in considering them. Then we shall pass on to some detail studies of how children develop in the lines whieh we try to eultivate in the schools.

The main underlying thought which we have been working out in these first four chapters, should be clearly before you now. All mental life is of interest to us because it develops. The subtle ehanges in the proeesses of thought and perception whieh go to make up individual development, will eseape us if we do not make them subjeets of eareful study. Even our own modes of thought are but half understood until we begin to look into their sources. If we will but have the eourage to undertake this study of ourselves and of the ideals of our times, we shall see that just now we are taking up a large idea whieh is destined to modify our edueational thought and methods more than they have ever before been modified in a single period of the world's history. This new idea, with all its derived principles, is the one whieh we are diseussing - the idea of development. Get at this idea from many sides. Study your own development. Study the development of your pupils. Study the stages and ends of development. Reeognize education as one phase of the broad proeess of development. 


\section{CHAPTER V}

\section{INDIVIDUALITY, ADAPTATION, AND EXPRESSION}

Is the last chapter we introduced the discussion of the gcneral principle of development, beginning with an illustration from biology, which served as the basis for the explanation of the terms variation, selection, transmission, and adaptation. We then pointed out how the doctrine of development disposed of the old dispute as to the goodness or badness of the child's nature. We called attention to the growing recognition in science and in practical education of the characteristic differences bctween different stagcs of mental development; and, finally, we concluded by pointing out the relation of the teacher, as a rationalizing factor, to the child's development, which, in its first stages, is wholly non-rational.

The first new application of the gcneral idea of development to which we now turn, grows out of a recognition of the significance of the term variation. We have already secn that variation is the necessary first step in both individual and racial progress. And it is obvious also that the advantages or disadvantages of variation are most keenly felt by the individual, for where the variations are advantageous the individual is selected and becomes an important factor in turning devclop- 
ment in the direction of his own superior characteristics, and, conversely, where variations are disadvantageous the individual suffers, and is selected for elimination. In the same way where one institutes a new mode of action in his individual life, and thus produces what we have called a variation in individual action, selection retains what is advantageous, and eliminates what is disadvantageous. And this process of selection goes on whether attended with pleasure or with pain.

Judged from a narrow view of individual life, it seems hard at times to see a single human being suffering the consequences of an unfortunate variation. Indeed, we have been passing, as a people, and as a body of teachers, through a period of thought in which we have rebelled against the mere suggestion that an individual could be sacrificed for the larger good of the race. The principle that all men are created equal has seemed to us so eminently desirable an ideal with which to inspire one's eflorts in life that we have held to it as one of the dearest dogmas of our democracy. We have held to it in a form in which human experience never justified our stating it. For if there is one thing that appears clearly in all human life, it is that individuals are not born with like tastes or capacities. Men are differentiated through the appearance of inevitable individual variations. Let men be equal before the law all you please. Let them seek on a common footing, even with equal opportunity, if you will, life, liberty and happiness, but their lives will be different, they will make different uses of their liberty, and their happiness will be of the most varying types.

The doctrine of development did not discover this 
fact of the existence of variations, it simply pointed out the value of variations for development. We can now recognize in a clearly explained fashion the necessity of individual variations. Variations are the first steps in development, and without them the larger progress of the race and of the individual would be impossible. Our view of life thus expands so as to include not merely the moment when there is pleasure or pain from the selection, but so as to include also the remoter and final advantage from the whole process of consummated development.

Gradually we are coming to accept a higher form of the idea of individuality. We are beginning to grasp the new idea in our school life. A few generations ago when our public schools were first organized, the children began at a certain age in the first grade and went on through the years of school life on the theory that they were always equal. Teachers knew that they were not equal, of course, but the theory was maintained. The theory was maintained sometimes in the expensive way of holding back some bright boy, or else of pushing some stupid boy forward. Teachers had no courage to face parents with the statement that all men are not. created equal. So firmly were our schools based upon this principle of equality that to separate a child from his fellows was a most noticeable fact.

How different it is coming to be! The school of to-day is striving for a new ideal of the child's individuality. If a boy has variations that are advantageous to him, we recognize it. Most boys have some advantageous variations, and we see that it is the business of the schools to find these and give them the em- 
phassis they deserve. In short, the school is coming to recognize individuality as a mark of differentiation rather than as the stamp of uniformity. A boy or a girl is seen to have individuality when he or she does things in his or her own way. If that individual way is good we foster it, if it is bad we cut it off and develop a substitute; for our work is to help make permanent the child's advantageous variations, and to eliminate his disadvantageous variations.

I need not dwell upon the changes in school organization which exhibit this change in our attitude on the question of individual character. We are coming to promote children now as individuals, not in droves. We allow boys and girls to follow, before they leave the higher grades of our schools, some of the subjects that shall best develop their natural powers. But more significant than these external changes in organization, are the changes which show themselves in the class room in the individual teacher's ideals. 'To the old pedagogue every shivering child was but another unit in his school attendance. Each pupil went through the same strenuous ordeal in the same way. The public school was, as some one so aptly put it, a great machine for polishing pebbles and taking the edges off cliamonds. The teacher of to-day is, more and more, grasping the ideal of individuality, and school work is showing the results in a broader, more human relation between the teacher and each individual child.

The broad way in which the ideal of individuality is being taken up is in no way better illustrated than it is in the clearness with which we recognize the harmony between our ideal of individuality and our ideal of edu- 


\section{INDIVIDUALITY, ADAPTATION, AND EXPRESSION 183}

cation in classes. We never think of putting a boy off by himself with a tutor, as the highest form of instruction. That is a treatment of individuality which seeks to draw the lines of exclusiveness about the boy. Individuality fostered by exclusiveness is not the kind of individuality we want. We want the boy to test the utility of his variations in contact with his fellows. We want him to profit by the advantages of imitation, and in this way to acquire some of the variations in action which originate with the other boys. In short, we know full well how to hold at once the ideal of social development and the ideal of individual development. We have the broader view of individuality, which means contact and relation with the world, not separateness. And so we are glad to put boys and girls into classes. We are sorry sometimes that the classes liave to be so large, but better large classes pulsating with individual life than the rarefied atmosphere of the exclusive circle of an individual or two withdrawn from social contact.

Coordinate with the individual, in our discussions of development, stands the environment. No one ever thinks of the process of devclopment without recognizing the fact that the individual variations are selceted and preserved or rejceted because they either fit or do not fit a certain environment. You recall our earlier illustration of the ground mole with its broad forefeet and weak eyes. These structures are fully developed in the sense that they fit the environment in which the mole lives. Examined by themselves, out of relation to the environment, the eyes of the mole would be judged to be failures, and the feet would probably be 
considered clumsy. It is only when we recognize the fact that scnsitive eyes would be worse than useless in the dark underground channels in which the mole lives, that we comprehend the reason for the line of backward growth of the eyes. But once we comprehend the relation of the mole to his environment, we see the reasons for it all. The failure of the eyes as cyes is entirely explained by the successful adaptation of these eyes to their particular environment.

One way of putting this matter of relation to environment is to point out that true development does not consist in mere refinement of functions for their own sake. Thus, if in contrast with the molc's eye, you examine the eye of the hawk or trout, you will find a very highly refined organ of vision. But you will have no reason for changing your verdict about the mole's eye in the presence of these examples of higher refinement of vision. The mole's eye is adapted to the molc's environment, though it is not as highly refined an organ as is the hawk's eye or the eye of the trout.

Or to transfer the discussion from the mole to human life, we too have certain functions which arc very little refincd. Among the human scnses, for example, smell and taste are notably defective as compared with the smell and tastc of many of the animals. We have heard educators of rank assuming that development meant refinement, and deploring this lack of sensory refinement in the human race. Indeed, I know of one family where, through the persistent efforts of the father, the children have been so trained in the detection and discrimination of odors that they can identify their friends in the dark through their keen olfactory 


\section{INDIVIDUALITY, ADAPTATION, AND EXPRESSION 135}

sense. These ehildren have a refined sense of smell. If refinement of the senses were the goal of edueation they would be far nearer that goal than most of us. But I venture to say that even before we have argued the matter out in detail, we shall all feel that human development has not been entirely wrong in its negleet of the senses of taste and smell. The truth is that even before men understood that true development meant adaptation rather than mere refinement, they had the word pedantry with whieh to eharaeterize those forms of ultra-refinement whieh extended beyond all praetieal purposes. As for the defieient faeulties whieh most of us eheerfully aeknowledge in many direetions-in smell and taste, for example-these are like the mole's eyes, faeulties whieh we do not need in our lives. We should be distraeted from the more important eoneerns of our environment if we were devoted to tastes and odors. We live in a soeial environment where the sense of hearing gives us more important information than eould possibly be obtained through the sense of smell. A refinement of the sense of smell would be wholly useless to our ordinary mode of aetion and thought, and would be quite out of harmony with even our bodily strueture. Did you ever notiee that the animals whieh have the most highly developed sense of smell are so eonstrueted that the organ of that sense is earried elose to the ground where alone it ean be advantageously used? Think of the dog or of the beasts of prey. And what have we as men to do with that ground environment? An Afriean traveler tells us of a tribe of natives who rely mueh upon the sense of smell, whieh they have developed to a very high degree 
of perfection. But, he adds, they generally go on all fours when they are following a scent.

Mere refinement of functions should never be the end of educational training. This has not always been recognized. There have been periods in the history of education when men devoted themselves so closely to the refinement of their use of classical Latin that they had no energy left for the real facts of their immediate environments. There are teachers to-day who would rather get at some detail of the Revolutionary War than have an intelligent understanding of their duty as citizens in a great peaceful republic. There are pupils who are led to believe that arithmetic consists in those intricate puzzles which get nowhere on this earth, and have no value, unless, indeed, the refinement of arithmetical acumen beyond all degree can be defined as having value.

There are certain difficulties in the application of this doctrine of adaptation, and we shall not overlook them. But before we come to these difficulties in the way of application of the doctrine to school work, let us pause for a moment and consider whether there is not a lesson for us as individuals in this principle of adaptation. How many of us are fully adapted to the environments in which we live? There is the young man or young woman, just out of one of the higher schools of the State, suddenly plunged into a farming community or into a small manufacturing or mining town. What is he or she equipped to do in such a community? Generally the teacher is equipped only to enter into the details of this or that form of thought and study, such as mathematics, or Latin, or literature. 


\section{INDIVIDUALITY, ADAPTATION, AND EXPRESSION 137}

Now, mark you, I have nothing to say against mathematics or Latin, or literature. The more the young teacher has of all these the better. But the trouble lies in the fact that this young teacher too often has no ambitions except to go on and on along these same lines. To use the technical phrase, the teacher is ambitious to refine more and more these particular forms of training. The doctrine of adaptation ought to come to such a young teacher with a new view of his duty to himself. There is nothing so worthy in life as to meet successfully the environment into which one is thrown. Even if you are going to outgrow this environment very soon and go to another, do not deceive yourself into the thought that you do not owe it to yourself to fill this environment with a well-adapted personality. A teacher in a farming community who knows so much mathematics and literature that he can find nothing of interest in the scientific studies of soil and insect life which are engaging the attention of many of our scientists-such a teacher has begun refining functions without laying the broad foundation of adaptation. He will find that he is not a force in the community. He will be regarded as curious and foreign to the life of the people among whom he moves, and it will be his own fault. And when he leaves that community, as he is very likely to, and goes to another, the probability that he will find a purely mathematical or literary environment is so small that it is safe to assume that he will again find himself an outsider. And with each successive move he will find his powers of adaptation growing smaller and smaller.

This fact that we as teachers spend our lives pur- 
suing refinement of functions is what makes people look on our schools as out of date, and it is a realization of the necessity of giving up the ideal of mere refincment for the broader ideal of adaptation, which is fortunatcly shaking us out of our slumbers and setting us about a complete and thorough revision of our courses of study. Who is not familiar with the demand which is nowadays so frequently made that our school courses shall train boys and girls for life in the working world into which they are soon to pass? And who is not aware of the change in the spirit and content of our cducation, which is coming as a concession to this demand? We see the increase of practical courses in business methods and in manual training. We see the physical cnvironment of the child presented in courses of nature-study. We sec the social environment taken up in elementary civies and history. In short, the movement in all parts of the country and in all grades of schools is in the dircetion of adaptation of the child to his environment.

Indecd, so overwhelmed are we with the new practical ideal of education that there is some danger of our failing to weigh carcfully the true difficulties in the way of its application. Let us stop and ask ourselves what we mean when we spcak of the child's environment. Think, for example, of the boy, who, instead of the course in history, is given a course in business arithmetic. What is the interpretation of the principle of adaptation in such a case? The teacher has evidently said to himself, this boy is going into business. He will come into contact every day with business problems. The historical facts, on the other hand, are facts which 


\section{INDIVIDUALITY, ADAPTATION, AND EXPRESSION 139}

lie far in the past, and will never enter directly into the boy's life. The conelusion seems to be direct, give the boy business arithmetic, and let history go. Again, here is a boy who will leave school at an early age and take up a trade. That boy does not need very much geography; he would be better off if his hands were trained in the use of tools. Let us give him manual training instead of geography.

One of the elearest indieations of our general aeceptanee of the prineiple of adaptation is to be found in the fact that we are perfeetly familiar in these days with sueh arguments in favor of business arithmetic and manual training. The argument docs not shoek us as it would have shocked our fathers. And yet I believe that most of us feel that there is something laeking in an ideal that is so direetly and exelusively praetieal. We feel that the child's environment has been defined in too narrow terms when we see in the environment of the boy going into business merely the humdrum of eommereial eompetitions and successes, or when we sce in the environment of the laboring man mercly his tools and his trade. One feels like saying, "Yes, let us reeognize in our schools all these praetieal demands, but let us try to see more in the ehild's possibilities than is ineluded in this narrow definition of environment." We feel, even where we do not see them elearly, some of the difficulties in the way of applying the prineiple of adaptation to our sehool work.

Let us face the question that we have raised. What is the true environment of the ehild? In the first plaee, we see more elearly to-day than ever before that the child must live a real life in the school and home com- 
munities in which he grows up. Do we regard these as his true environment? In some sense, yes. We must treat of this immediate environment in our study of education. There are some teachers who have not yet waked up to this fact that they must pay attention to the life in the school and in the home. They think only of the large world which lies beyond the child's present grasp. They would distinguish between the child's immediate environment as transient and unimportant, and the future environment in which the child is to live, and would consider the latter as the real environment to be recognized in education. For such teachers, education is always an anticipatory adaptation to something yet unseen. On the other hand, there is fortunately an increasing group of educators who regard it as a mistake to think exclusively of the future. They would define the child's environment in such a way as to recognize very much more fully the present. Hear, for example, the words of Rousseau, where he says: " "What must we think, then, of that barbarous education which sacrifices the present to an uncertain future, which loads a child with chains of every sort, and begins by making him miserable in order to prepare for him, long in advance, some pretended happiness which it is probable he will never enjoy?" And, later, hear him lay down the positive side of his doctrine: ${ }^{2}$ "The first education," he says, "ought to be purely negative. It consists not at all in teaching virtue and truth, but in shielding the heart from vice, and the

1 Payne's translation of Emile, p. 44.

${ }^{2}$ Ibid., pp. 59, 60. 
mind from error. If you could do nothing and allow nothing to be done, if you could bring your pupil sound and robust to the age of twelve years without his being able to distinguish his right hand from his left-from your very first lcssons the eyes of his understanding would be open to reason. Without prejudice and without habit, he would have nothing in him which could counteract the effects of your endeavors." Certainly this is an unambiguous plea for the school to think of itself as the child's true environment. To be sure, the present environment in such a school of negative education would not be a school with desks and blackboards. It would be rather a playground with objects of nature about the child.

Conceiving of the child's immediate environment as rich in present experiences, there can be no doubt that our modern education is coming to give more and more attention to present adaptations. We show the children a plant and tell them how to cultivate it and use it. This is adaptation to the natural surroundings of the child, and it breaks in upon the monotony of ever preparing for the future as they used to in the school of yesterday. This is a step toward practical education.

We see the schools of to-day taking up studies of domestic occupation, and of healthful recreation. We sec the boys and girls trained in play and in physical exercise. To the old-fashioned educator all thesc activities were too trivial for the school. The natural surroundings of the child were supposed to impress themselves upon the child without any supervision, and the school concerned itself only with the remote future. Certainly we have gained much by these changes. 


\section{GENETIC PSYCHOLOGY FOR TEACHERS}

In our high sehools we see the same tendeney. The sehool eommunity organizes itself into athletie associations, literary assoeiations, and even into general governing bodies eontrolling the whole life of the school. There is in all this a reeognition of a real social environment in the sehool itself, not in some remote social world of the future. This attention to present adaptations is in keeping with the highest and best understanding of development as a proeess of adaptation to environment, a part at least of that environment being the immediate surroundings.

While we laud these efforts to bring about adaptation to the ehild's present environment, let us not fail to see that there is danger that in the midst of all this attention to present environment there shall be no adequate reeognition of the larger problem whieh unquestionably lies beyond. For we all of us know that the child must some day live in an environment whieh is not like his present environment. We know that his present adaptations must be made the stepping-stones to the larger adaptations into whieh he is to rise. The mistake of the old edueation was that it negleeted the present too mueh. The danger of our present system is that we shall make no explieit provision for the future. There is sueh a thing as studying oeeupations in the home eity so long that the boy and girl shall have no adequate notion of the large world beyond. There is danger that plants and animals shall be studied to sueh an extent as to exelude the boy and girl from a thorough mastery of the elements of some of the less immediately applieable, but no less essential, adaptations of arithmetic and reading. We must not lose sight of the faet that 


\section{INDIVIDUALITY, ADAPTATION, AND EXPRESSION 143}

adaptation to any given environment is never of the true type unless it leaves a certain amount of energy and attention free to go still higher and to seek out wider ranges of environment.

The great difference between the lower grades of human and of animal life and the higher grades, is that the lower grades of life are limited in their adaptations to certain narrow environments. All these lower adaptations consist in changes due to direct individual contact with the facts to which one is adapted. Think first of animal adaptations. The ground mole, for examplc, develops a broad foot for digging. That is a direct adaptation, and it serves only to fasten the animal to his narrow environment. The street gamin bccomes adapted in very much the same direct fashion to his environment. But direct adaptation is not the highest form of development. Man's adaptations at the present stage of development consist chiefly in indirect adaptations. Thus, man has developed a varicty of indirect devices for digging, and he does not necd to develop individual bodily organs such as the mole has. Man may have a variety of methods of meeting the same situation. This makes possible the use of one mode of adaptation, while at the same time it permits the enlarged development of a higher, broader mode, without impairing the first.

This is exactly what we should aim to recognize in our education. Suppose we want to train the boy to meet advantageously his relations to his physical enviromment. The first and most available method is to bring him into direct contact with the natural objects which are a part of his immediate environment. This 


\section{GENETIC PSYCHOLOGY FOR TEACHERS}

is the only way in which the animal or any undeveloped individual comes to know nature. But it is not the only, or even the most comprehensive way that man has, for man has, besides direct contact, a way of gathering into books observations from all over the world, and laying them before the boy. The boy can not go to Greenland or to the equator. If his only method of development were that of direct contact, he could not know nature in these remote regions. There is need, accordingly, of training in the indirect modes of knowledge. We recognize in present-day education that it is a great mistake to take the book method of bringing the boy into contact with naturc before we use the direct method, for books are good to enlarge the boy's environment, but they do not constitute his most direct path of approach to inmediate environment. Clearly the true method of training the boy is to give him first direct contact with naturc and with the social life about him, and then give him the means of enlarging his natural environment by means of books. Do not become so absorbed in either direct environment or in the books that you neglect the other. The neglect of direct environment was the mistake of the bookish education of the past. The neglect of the more general, indirect means of adaptation through books, is one of the menacing dangers of our present derotion to direct adaptation.

It ought to be clear through such discussions as these which we have been following, that man's dcvelopment, while it has much in common with the lower forms of development, has a range which is immensely broader. The young animal endowed with the struc- 
tures of his species has only to grow up and come in contact with his social and physical environment, and exert himself in the regular activities of getting food and providing for himself and family, and his work in life is done and his development is complete. Such an animal has a narrow range of environment to which he is adapted, and in which he must live. A man might develop in very much the same way. The savage boy does, indeed, follow the same formula of education. And it looks very much as if the highest ambition of certain educators is to foist upon the human race this same formula of direct adaptation, as the highest definition of education. The truth which these educators have is by no means to be overlooked. It is the great truth that, like the animal, the human being needs much direct adaptation. But there is the larger truth which must also be recognized. Man has multiplied vastly the range of his adaptations by the development of the power of indirect adaptation, and now a single man may come into contact with a vast environment and may fit himself to it. Spencer, at the close of one of his chapters, calls attention to this vast extension of human environment in the following examples: ${ }^{1}$ "From early races acquainted only with neighboring localities, up to modern geographers who specify the latitude and longitude of every place on the globe-from the ancient builders and metallurgists, knowing but surface deposits, up to the geologists of our day whose data in some cases enable them to describe the material existing at a depth never yet reached by the miner-from the savage barely

' Principles of Psychology, vol. i, p. 318. 


\section{GENETIC PSYCHOLOGY FOR TEACHERS}

able to say in how many days a full moon will return, up to the astronomer who ascertains the period of revolution of a double star-there has been a gradual widening of the surrounding region throughout which the adjustment of inner to outer relations extends."

The broad range of human adaptations, and of the human environment, is a fact which teachers should keep in mind as they try to work out the problem of school training. It is not full human adaptation when a carpenter is adapted merely to his bench and tools. It is not full human adaptation when the young man becomes a cog in the wheel of business and nothing more. Our schools have a higher duty than mere commercial training. They have a larger task than to keep children at the level of the narrow-sighted present. They have it as their best function to prepare for the narrower and also for the broader adaptation. They should show the boy what is about him, and they should also show the boy how to reach what is beyond.

Thus, we see that the acceptance of the principle of adaptation does not in any degree curtail the largest hopes or ambitions for school training. Let us not be narrowed by our new ideal. For while our new ideal is giving us much firmer ground to stand on, while it is clearing up for us the relation of school-life to the present, it is in no way lessening our duty to the future. Practical education as the basis for liberal education is the true ideal. Never confound this with the false maxim that practical education is a substitute for libcral education.

We have come back, as you will see, through this discussion of adaptation to cnvironment, to the point 
at which we began our study of the idea of development. The ideal of adaptation is one which lays greatest stress upon activity, not receptivity. An individual adapted to his environment is not an individual who has passively received something, he is rather an individual who has met his environment in an active way, and has fitted himself to that environment through his own exertions. The whole modern discussion of education is ringing with the word activity. We do not give children their mental development, we help them to get it through their own endeavors. We talk of expression and self-activity as the fundamental necessities for individual development. And we have come to think of both mental and bodily activity as most intimately related in working out the ends of individual development. Some of the facts which go to establish the relation between bodily and mental activities have been reviewed in an earlier chapter. Let us eome back to the discussion with more faets to establish this relation and show its signifieance for development.

Every one recognizes the importance of what we call attention. The ehildren in the school are urged to give attention to this or that. Taken in a broad sense, attention to an object means making it a eenter of active adaptation. The boy is attending to the ball, which he tries to catch. In terms of his development this means that the boy is concentrating his whole nature for the time being on that ball, and is striving to fit himself and his ball environment to each other. Nothing could show better the completeness of this relation of attention to adaptation than a study of the bodily conditions of attention. 


\section{GENETIC PSYCHOLOGY FOR TEACHERS}

The bodily eonditions of attention eonsist in a series of aetivities. In the first plaee, every sense organ fits itself by activity to the objeet of attention. Both eyes move in their soekets so as to look direetly at the objeet. Within each eye, the fine museles whieh eontrol the lens are straining to get the lens in the best possible condition to give a elear, sharply defined image of the objeet. Even the head may be bent forward so as to bring the eyes nearer the objeet, and at times we literally get up and move toward the eenter of attraetion. If the object is one that gives forth sounds, there is a similar adjustment of the ear. There is a eontraction of the little musele whieh stretches the ear-drum so that one has a well-stretehed reeeiving surfaee, sensitive to the slightest sound. The head is turned so as to bring the ear toward the souree of sound, and one investigator reports that he was able to demonstrate even in human beings, movements of the outer ear of the same type as those whieh we see very clearly in the animal, though these human ear movements were fortunately less intense and mueh less notieeable.

The senses of taste and smell also have aetive adjustments. Thus, when we attend to tastes, the salivary glands beeome very aetive, and furnish the liquid in whieh to dissolve any substanee eoming to the mouth. This is an important aetive adjustment, for only fluids can affeet the organs of taste. Similarly, when we attend to odors we snuff the wind and the nostrils dilate, even though we make little use of this sense. In the case of animals, of eourse, there are very noticeable movements aceompanying the aetive turning of the senses of taste and smell upon a given objeet. 
The sense of touch is perhaps the most actively adjusted of the senses. We can not attentively see or hear, or otherwise recognize the presence of an object, without making an active effort to grasp it. This active adjustment of touch has been suppressed in part through long periods of social training which forbids our seizing everything which we see, but the movement is there, nevertheless. Attach the hand to any delicate recording apparatus and you will see that it moves in the direction of any object of attention. Some persons have grown very skilful in leading others to the object of their attention by holding their hands. This socalled mind-reading, or better called muscle-reading, is by no means a difficult task. You can usually find in any party of five or six, some one who makes sufficiently intense movements of the hands toward objects of attention to become a suitable subject for even amateur muscle-reading.

A great many experiments have been made to show the presence of involuntary hand movements toward objects of attention. Professor Jastrow has recorded ${ }^{1}$ a series of experiments with the planchette, or writing board. A sheet of glass placed on rollers and having a tracer attached, is brought under the hand. The subject without looking at his hand, thinks intently of reading across a page of print, or he recalls a poem, or thinks of a tower, and the hand moves noticeably, following the shifting of the attention.

One of the best practical illustrations of hand movement following attention is to be found in the case of

1 Fact and Fable in Psychology. 
the learner on a bicycle. Let such a learner try to pass some approaching object which attracts his attention, and the chances are he will run into the very object which he was trying to avoid. The explanation is very simple. He could not help moving toward the object of his attention. The hand movement, which turned out so disastrously on his bicycle, would not have becn noticed if he had been walking. But a hand movement when a hand is guiding a bicycle is a much more important matter as the consequences showed.

Attention means, as these facts indicate, the active conccntration of the senses on the object attended to. But it mcans more than this. Have you not felt the mustering of all your vital forces as an essential part of the most intense attention? One holds his breath in order to kecp his trunk muscles ready for action. One fcels the muscles of legs and arms grow tense. The very beating of the heart stops, ready to begin again at a furious rate as soon as the suspense of waiting attention shall give place to the attention of real action. All this shows how the mental state of attention is a process of active adaptation.

Or turn the matter about and see what arc the effects of activity upon the character of idcas. What part of the streets of your native town do you recall most clearly? Not the long, unintcresting stretches where you never stop. It is the corner where you make the turn, it is the house at which you are accustomed to stop, that you think of most clearly. These are the parts of the strect which are of practical importance. They are the parts to which your actions are directed, and where action is directed there attention is directed. 
Nothing can be clearer than this conclusion that mental activity and bodily activity are both working toward the practical adaptation of the individual to his environment. The chief consideration in our presentday study of mental development is not the impression that goes in at the eyes or ears, but rather the way in which attention is adjusted to these impressions, and the way in which action is directed by attention.

Again turn to that whole group of mental processes known as the cmotions. A few years ago two scientists ${ }^{1}$ advanced what was at that time a novel and bewildering proposition, namely, the proposition that the emotions are not conditioned merely by impressions, but are conditioned also by the way in which the individual reacts to these impressions. There is much scientific truth, they said, in the old advice to keep up your courage by whistling, for no matter what your surroundings are, if you can act as if you were cheerful, you will find that your emotional state will correspond to your actions rather than to your impressions. This theory of the emotions, now known as the James-Iange theory, has leavened the wholc lump of our psychological thought. We no longer think it strange that one should emphasize the active conditions of emotional life, or, indeed, that one should emphasize the active conditions of any phase of mental life. We are quite willing to accept in some form or other the proposition that action is quite as important as impression.

All the careful experimental studies of the emotions

1.Professor James and a Danish physiologist, Professor C. Lange. 
recently made, go to show that the different types of emotions are directly connected with different forms of action. Let us review one of the typical experiments. Train a blindfolded person to move the arm back and forth through any convenient distance, say, for example, a distance which measured at the fingers amounts to about a foot and a half. One can learn to make this movement with a good deal of uniformity. The movement depends on two groups of muscles: those which carry the arm outward and are called extensor muscles, and those which draw the arm inward and are called flexor muscles. Both extensor and flexor muscles are more or less active during the entire movement, even when not drawing the arm in the direction of their special contraction. Suppose now that some influence should make the extensor muscles at the beginning of the movement tenser than usual, and should leave the flexor muscles unaffected. The result would be that the arm would move in the direction of the tense extensor muscles easily, and in the opposite direction less easily. This is exactly what happens when one is given a pleasurable sensation of any sort. Give a person a sweet taste, for example, and you will find that his outward arm movements are longer than they normally were. These longer outward movements show that the extensor muscles are unusually tense. Conversely, if one gives the subject a bitter taste or a disagreeable sensation of any sort, the flexor muscles will be unusually tense and the outward movements will be curtailed.

Other experiments also confirm the general principle that all pleasurable experiences express themselves in large expansive movements, or in tensions of 


\section{INDIVIDUALITY, ADAPTATION, AND EXPRESSION 153}

the muscles favorable to such movements, while unpleasurable experiences express themselves in contracting, withdrawing movements. And even passing from these to other forms of experience, we find everywhere the same characteristic fact, that each emotion has its characteristic motor conditions.

The value of emotional reactions in the development of the individual can not de doubted. Darwin ${ }^{1}$ was the first to attempt a detailed explanation of the utility of emotional reactions. Whether we agree with his analysis of the various emotions or not, we have to recognize the fact that he set the pattern for modern explanations of the emotions in that he sought to find their value for development. The great value of many of the human emotional expressions is probably to be found in their utility as means of social communications. But some have other values as we see, for example, in the protective function of the emotional reactions which withdraw the body from disagreeable stimuli. Or again, the reaching out after objects which give pleasure is evidently in keeping with the general fact of development that in the great majority of cases pleasant experiences are favorable to individual life.

These special groups of facts which appear when we study the active conditions of attention and of the emotions, are typical of all phases of development. If one wishes to understand individual development, he must study not merely the impression side of the individual's life, he must study more especially the expression side. Impression is, of course, necessary to develop-

1 Expression of the Emotions. 
ment. Impression is the means by whieh the environment produces its first effect upon the individual. If an individual were not sensitive to his environment, the later adaptive proeess would be impossible. But impressions are present in superabundanee at all stages of human life. So far as the sense-organs of the boys and girls in our schools are concerned, we have no reason to believe that they do not reeeive the same number and kind of impressions that our own sense-organs receive. Nature has thus provided that the environment shall produee its first effects, long before the boys and girls can fully make use of these impressions. The raw materials for adaptation, the impressions, are there very early, waiting for the individual gradually to adjust himself to them.

The active adjustments of oneself to impressions is the real adaptive proeess. All the sensations must be distinguished from eaeh other and the individual must learn how to react to eaeh impression. Certain groups of impressions must be treated in groups, not bceause they are alike as impressions, but because they are all objeets of a single form of reaetion. In short, so far as this raw material for development which presents itself in the form of impressions is concerned, it must all be worked over and eonnected with individual reaetions before it ean be regarded as really assimilated by the developing individual.

Take the form of training whieh we call sensory training in the sehools. We present certain sense stimuli, such as colors, and sounds, and sensations of touch. Do we do this for the sake of developing the receiving organs? Not if we understand the process 


\section{INDIVIDUALITY, ADAPTATION, AND EXPRESSION 155}

aright. The colors that fall on the eyes, the sounds that fall on the ears, are all received, so far as mere reception is concerned, by organs that were given to the individual through the development of the race. The individual life is too short a span in which to modify appreciably the development of cye or ear as sensitive organs. This appears in the fact that ecrtain eyes which are defcetive in sensitivity, the color-blind eyes as we call them, can not be improved by individual development. Indeed, it often requires two or three generations of fusion with well-developed individuals to correct color-blindness, so thoroughly is the condition of the sensory organ determined before individual development begins. Individual development bcgins at the point where racial developinent ends. Our sensoly training takes the sensory impressions after they are received, and, first of all, sharply discriminates them, and then organizes them.

Discrimination is not a process of impression. How often one has heard two sounds, for example, two sounds in a foreign language, and has confounded them. When we hear Chinese, for instance, or even French, if we do not understand it, the sounds all seem to run together in a confused mass. The different sounds are there so far as the recciving process is concerned, but we do not discriminate them. Now, instead of merely listening to these sounds, begin to try to reproduce them. That is, change from the attitude of impression to the attitude of expression, and as you try to fit your active life to each of the different impressions, you begin to discriminate and recognize. In other words, you begin to have more than the mere impression, you begin to 
have recognized impressions. This is sensory training. It is not training of the sense-organs, it is training in discrimination and in reaction to sensory impressions.

Nowhere does the relation of mental development to activity appear more clearly than it does in the unities which we build up in experience and call ideas. Every experience of visual or auditory recognition is, on its impression side, a complex. Every object at which we look, makes a series of impressions upon us. But we do not get an idea which is broken up into parts. We see things in the same unitary way as that in which we react to them. The fact that our action and thought are adapted to unitary objects rather than to single attributes of objects, is evidence of a close relation between ideas and actions, not between ideas and impressions. Thus, when we look at a piece of iron, the sensory stimulation received by the eye is not separated in our action or in our thought from the other attributes of the object. The color fuses in our idea with the weight, and the weight fuses with the roughness and coldness, and altogether we act toward the piece of iron as toward a single object, not as toward a group of colors, weights, roughnesses, and temperatures. The action and the idea correspond in that they are both unitary complexes containing in modified form the net results of all the varied sensory antecedents.

Striking parallels can also be found between the more complex unities of consciousness and action. Thus, take the case of the piano-player. At first his activities are a series of single, separate responses to separate notes. But later he strikes a whole chord in 


\section{INDIVIDUALITY, ADAPTATION, AND EXPRESSION 157}

a single moment. Or take the singer; one may be able to sing cach note of the scale separately and not bc able to sing even a simple line of music. What must be learned in these cases? It is the combination of the elementary movements into new wholes, so far as the action is concerned. And when such combinations of activitics are once established, we have corresponding complex ideas. The ideas of a musical chord, and of a vocal transition, are to the trained mind, unitary wholes, not merc aggregates of impression elements. And while these wholes contain, in a certain sense, the differcnt sensory elements, they are in a much larger and more important sense, unitary processes with characteristics depcnding upon the fact that the elements are unitcd into a single idea.

We have, however, dwelt long enough on these illustrations. The general principle to which they all lead is the general principle that development is adaptation, and adaptation is an active process. The individual has many. functions, but all these functions cooperate in his higher and higher development, and that means that they all cooperate in working out more and more adequate forms of activity.

These, then, are somc of the new ideals that are growing up in our education. We shall be blind to our own individual advantage if we do not see that the new spirit which springs from these new modes of thought is worthy of our individual study and acceptance. We shall be equally blind to our own advantage if we do not see that we can not fully grasp the newer spirit without understanding the fundamental idcas which underlie it. 
There is a good deal of doubt in the minds of some teachers as to the value of their taking up some of these general lines of consideration. Give us methods and deviees, they say. Let the leaders in edueation, let the superintendents, if you please, work out the larger problems and give us the result. But this is an idle demand. The method may be ever so perfeet, the deviee may be ever so well wrought out, and yet fail unless administered in a right spirit, and the spirit can never be cultivated by mere superfieial imitation.

Our edueational life is full of dangerous opportunities to eultivate false and superfieial ideals. Teachers are, as we have already said, more than most people dependent on their ideals. And espeeially at this period when the air is full of pedagogieal doetrines from the North and from the South, from the East and espeeially from the West, it behooves eaeh one of us to have a real, genuine ideal to save us from errors.

The history of the past has been a history of vague striving after such safe ideals. Men have borrowed their ideals from the ehureh, from their philosophy, from their neighbors, from their teachers, who in turn borrowed their ideals from earlier teaehers. Slowly the struggle has gone on and has brought us to these times. IJere again there is large opportunity to borrow if we are so disposed. The traditions of the sehools are ever present as fertile suggestions. The suggestions of our neighbors are offered even more freely than in former times. We may horrow; but you know the result of sueh borrowing. We ean not borrow any more as they used to in the good old days, for we are in an age of rapid progress; the next piece of borrowing that we try, 
may upset our whole system. It is the blind borrowing of ideals that makes the teaeher of this generation anxious and worried. It is the Babel of tongues without any single voiee of authority, and this is what makes us feel eonfused. What is to be the relief? Are you going to wait until some one shall eome and silence all this wrangling? If so you have a long dreary life ahead of you. There is to be mueh diseussion of educational doetrines from this day on. You ean not silenee it or suppress it. The thing for you to do is, prepare to meet it. Have some ideal of your own. Get a broad prineiple, and then enter into the active disenssion of details yourselves, and be, eaeh one of you, a faetor in the edueational thought, not a eonfused outsider.

This is eertainly not too large a demand to make upon our teaehers. I do not suggest that you try to write articles for the edueational reviews. That seems to be a dangerous sort of dissipation at the present time. I do not even suggest that you write a book. I certainly do not ask you to read all the books. But I do ask that before you let yourself adopt a plan of work in your elasses, you eonsider some of the reasons for your plan. If it is writing that you intend to teach, or reading, or arithmetie, do not simply go ahead without any eonsideration of what is the value of this study for the boys and girls. Do not enter upon a lesson without thinking over its aims and purposes. You try to make the boys and girls think about what they are going to do before they do it, why should you not think about what you do?

And so I bring this general diseussion to a elose with 
an urgent recommendation to you that each one of you think himself or herself into the modern view of education. There is not one of you who could not, and should not, understand the main outlines of this broad and fruitful idea of development. It is an idea that will illuminate your whole work. It will make it easy for you to understand that children improve slowly. It will give you a new spirit of tolerance of their undeveloped states. It will give you a broader ideal of the purpose of education and its relation to the other phases of the child's life. And above all it will give you a basis on which to build your methods, and it will give you suggestions as to the particular problems which you should take up for further investigation. 


\section{CHAPTER VI}

\section{THE TEACHER'S WRITING HABIT}

Is the preceding chapters we treated of some of the general characteristics of our mental lives and of some of the general ideals which influence us in our work as teachers. We turn now for a time to more special topics. How we write, and read, and use numbers, are the topics to which I shall now ask you to direct your attention. These are, in a gencral way, certainly not new subjects, and $I$ am wcll aware that you have, before we enter upon the discussion, a good many valuable ideas on how children should learn to write and read and use numbers. But $I$ wish we might set aside for a little time all that we know about how children should do these things and might approach the familiar subjects from a somewhat different point of vicw-the point of view of our teacher-study. How do you and I actually behave when wc writc? This is a somewhat different question from the one with which we are more familiar, the question which asks how we shall teach children to write.

Our question is one of self-study. It is not especially a question of self-examination, for I do not wish you to examine your writing with a view to comparing it with some copper-plate model. I wish rather to 
induce you to stop and think that you, as a trained adult, have the habit which your children are working most earnestly to acquire. You, as a trained adult, can take a pen or a pencil, or a piece of crayon; and you can, rapidly and without apparent effort, express ideas by means of written symbols. What is this habit of which you have such complete control? It certainly is not an abstract or theoretical affair. There is a very great dcal of your concrete personality involved in it. Did you cver stop in the midst of all your pedagogical struggles to think that in writing, as in many other respects, you are your own best subject for study? Did you ever think that when you sit down and study this or that so-called systcm of penmanship, you are studying somcthing very remote and abstract, something that contains very little of the human beings who have to produce such letters and use them in rcal life? I wish I might draw your attention to the habit of writing as a human performance, to your own habits in writing as profoundly interesting illustrations of what education is aiming at. For, if I mistake not, education aims to cultivatc human habits of thought and expression-not forms and symbols. One of the troubles with our teaching of writing has been that we have had our eyes too much on the lifeless, material paper and ink, and not enough on the pulsating human being back of these material things. The habit of writing is not to be found in lines on paper-it is in human beings.

Perhaps it will not be amiss for me, as we enter upon this study of ourselves and of our ability to write, to assure you that this is no subtle scheme by which 
to induce you to accept some new form of penmanship. I solemnly promise not to turn out to be an advocate of some new series of writing books, or even a representative of one of the publishers now dealing in writing books. If I were to give an opinion growing out of a careful perusal of a good deal of what has been written for teachers on the subject of writing, I should not hesitate to say that the multiplication of new writing books and the multiplication of pamphlets and even volumes in support of these numcrous systems of penmanship, nust be recognized as very largely accountable for the deflection of the attention of teachers from the really important questions of the nature of writing habits, to the less essential and often wholly unessential characteristics of this or that system of copics. Let us agree, then, that this is not a study of systems of penmanship, but a study of the nature of the writing habit, beginning with a careful examination of developed writing as exhibited in the teacher.

Writing involves as its most obvious factor a complex muscular movement. Our study of developed writing may well begin with this obvious factor. One does not need to know very much about the muscles of the hand and arm to recognize the fact that there are a great many of these muscles involved in writing. Thus, one must carry his hand across the page on which he writes. This movement across the page is performed by the larger muscles of the arm. It is a movement in the shoulder-joint and at the elbow. This movement is vcry different, in regard to the muscles which it involves, from the finer finger movements which ordinarily make the pen-strokes. I say ordinarily, for 


\section{GENETIC PSYCHOLOGY FOR TEACHERS}

there are, of course, certain special modes of writing in which all the movements are arm movements. And even if one insists on talking about these relatively unusual forms of arm-movement writing, the same general proposition is true. The lateral movements across the page are different in character and in the muscles employed from the rotary movements by which the letters are formed.

When one begins to notice this fact, that writing movements are made up of a number of different factors, he begins to notice in the same connection that all the different factors fit each other perfectly. The finer pen-strokes and the movements of the arm across the page do not interfere with each other. The arm muscles do not contract too soon, but wait until the finger-work is done, and then easily and fluently, without our noticing that an entirely new movement is being woven into the total complex of action, the arm muscles carry the hand forward to a new point where now pen-strokes are to be executed.

Or consider the ordinary finger movements by means of which most of us make the pen-strokes. It will be clear to you after a little observation, that the thumb does not perform the same kind of movement as the first finger, and that the middle finger does not perform the same movements as either thumb or first finger. The first finger makes the downward strokes. In these downward strokes the thumb and middle finger simply guide the downward movement and gire to it its inward and outward curves. The returning upward strokes of the pen are very largely the work of the thumb. The guiding of the upward movements is 
the work of the first finger and the middle finger. Put in a general way, one can say that thumb and first finger do most of the active work in the upward and downward pen-strokes, while the guiding of these strokes is the complex result of the cooperation of all three fingers.

The cooperation of the three fingers is, like the larger cooperation of the arm and fingers, so nicely adjusted that we do not notice the complexity of the movement in ordinary experience. We should ordinarily describe the stroke of the pen as a single movement. It is in one sense of the word a single morement, but it is single only in the sense that its factors, which are many, are perfectly fused so that there is no interference or lack of harmony. The various muscles are perfectly timed to each other and perfectly regulated with respect to intensity of action.

All this cooperation of the different muscles must, of course, be due to some controlling system which sends to each muscle at the appropriate moment the proper command to act. The muscles themselves have no power of uniting with each other. They are separate organs. Their cooperation is due to the nervous center with which they are all connected. And so our first consideration of the external muscular movements in writing, leads us to a study of the way in which these movements are controlled and initiated.

Every muscle is supplied with a delicate nerve-fiber. You know enough about nerves and their connections so that we need not go into any extended discussion here of the details of nervous structure. No muscle ever moves except as it is aroused to action by its 
nerve-fiber; and no nerve-fiber ever arouses a muscle cxcept as it receives its impulse in turn from the brain. When, now, we find a group of muscles acting in perfect harmony, as do the writing muscles, we can explain that harmony by the fact that in the brain there is a group of nerve-cells all connceted with each other and so organized that they produce from a single region the combined harmonious action of the different muscles. We speak of this organized group of cclls as the center of muscular coordination. And by muscular coordination we mean the fact of cooperation which we described a moment ago.

Developed writing movements depend, then, on the existence of a group of brain-cells which are interconnected and interrelated in a most complex way. The growth of this series of interconnections between the cells was a process that required time and practise. At the beginning of this practise each cell acted in a large measure apart from its fellows, and there was no wellorganized cooperation, or muscular coordination as we have learned to call it.

One can get a notion of what the condition of things must have been beforc the cells became organized, through certain disorganizing experiences which one has in adult life. Suppose you are writing and a sudden peal of thunder sounds in your ears. You know the result. Your pen flies off in some unexpected direction, spoiling the line you were just about to complete. Even a milder noise than thunder will often make one start and spoil a pen-stroke. These failures of the writing muscles to cooperate in the usual fashion when one hears loud, sharp sounds, are explained by the fact 
that the thunder, or the other loud noise sounding in one's ears, sends into the brain very strong excitations which stir up the whole brain. The excitation is so great that it does not respect the usual channels of well-organized discharge into the muscles. Instead of flowing out as a well-coordinated impulse, this strong stimulation leaps forward on its own arbitrary paths, and those eells which it excites most intensely simply break away from the system to which they belong and act independently of the system, just as in earlier times they acted independently because the system was yet unformed. This independent action of eertain nervecells breaks up immediately the harmony of the movement. We see the value of the ordinary coordination in contrast with this lack of coordination.

Nothing could be more instructive for the teacher than to study these irregular movements which are made under the influence of some sudden, strong stimulation. You find it impossible to make a regular movement under these eonditions. If some one should, at sueh a time, preach you a long sermon on making the letter eorrectly, it would not help matters any. The faet is, the wrong movement was due to a lack of ability to make the right movement. The machinery of coordination broke down at that instant and the false movement appeared. Now you know how to sympathize with your pupil whose maehinery of movement has a good many weak points. Impulses go astray in your pupil's nervous center beeause the center is not eompletely organized. It does no good to preaeh to him about correct movement-at least, if you preach to him in the spirit of blaming him for the wrong 
movement at the wrong time. He does not choose the wrong movement. He has before him a problem very difficult for us to understand, namely, the problem of making any movement that shall even approach what you want and what he wants.

There is another kind of experience in adult life which will help us still further in our effort to comprehend what is meant by a coordinated movement. Think of a movement which even in adult life is wholly unorganized. There are muscles in our bodies which are supplied with nerve-fibers but which we have never learned to use. For the sake of understanding the child's feelings about his writing lesson, try sometime to write with your own undeveloped muscles in your fect. This is not an absurd proposition by any means. There are a great many people in this world who, for one reason or another, have learned to use the feet very dexterously, and some have even learned to write with them. Of course the feet are not as well adapted to fine work of this kind as are the hands, but if you will make the trial you will find that your immediate difficulty is not that there is a lack of muscular activity, or even that there is a lack of general adaptation of the organ to this kind of movement. Therc will be movement enough and to spare, and there will be movement which, if trained, would do the work very well. The first fact which you will discover is that the movements which are present, are not coordinated. They are not under control. A little experience will show you how hopeless it is to try to do anything with these untrained movements except through patient practise. You must have the nervous organization 
before you ean have the eoordinated movement. And this is exaetly what is true of the muscles of the child's fingers, hand, and arms.

If, now, the general charaeter of the writing movement, as a eoordinated movement, made up of many factors, is elear to you through these contrasts, we may turn to the study of some of the charaeteristie forms of writing movement. It is obvious, of eourse, to all of us that there are great individual differenees in writing movements, and it is also true, as we shall see, that the explanation of these individual differences must be sought in the individual modes of eoordinating movements. It is not ehiefly, if indeed it is at all, differenees in the shape or size of the hand, or differences in the eharaeter of the writing materials, which determine these individual differenees. The way in whieh one writes will be determined in a measure by the materials whieh he uses and by the strength and shape of his museles. But these are very seeondary faetors. The ehief eonsideration is the nervous organization whieh controls the coordination of the muscles. In other words, one's individual writing is the expression of his individual habit of movement. His hand may be large and strong, but if writing is for him a series of fine delieate eoordinations, then his writing will not show the size or strength of his hand, but will express rather, by its fine delicate lines, the eharaeter of the eoordination.

We can see even by superficial examination of a number of adults that their habits of movement are very different. Ask two persons to sit before you and. to write a given word over and over again, and watch 
their hands and arms and compare their modes of movement. You could tell that the products of these movements must be different from the very fact that there are such noticeable differenees in the movements. But we shall not be satisfied with this superficial observation of what can be seen directly. Let us resort to a thoroughgoing experimental analysis of a number of individual coordinations.

Such an experimental analysis is not difficult, at least in so far as the grosser coordination between the arm novements and other movements is concerned. One can arrange a tracer in such a way that while one is writing as usual with the fingers, the tracer shall record, not what the fingers do, but only what the hand as a whole does. All that is necessary in order to make such a tracer, is first to find some part of the hand that does not participate in the finger movements. Such a part of the hand is, for example, the hand bone, or so-called metacarpal bone, just back of the little finger. This metacarpal bone moves every time the hand moves, but it has no part in the movements of the thumb and first two fingers. A simple tracer of the sort represented in Fig. 14 is fastened to this bone.

The tracer consists of a spring $(A)$ which fits closely on the hand and carries the light rod $(B-B)$ which runs forward far enough so that the distance of its end from the wrist and elbow is the same as the distance from the wrist and elbow of the pen held by the thumb and first finger. This equality in length ensures a record of the hand movement which is on the same scale as the writing, and thus comparison 
is made direct and easy. At the end of this rod is placed a perpendicular glass tube $(C)$, and through this falls a closely fitting pencil $(D-D)$. The record in any given case is made by writing naturally and allowing this tracer, whieh is fastened to the hand during the writing, to make a record on the same paper as that which receives the writing. The written letters are the records of finger movements plus all the hand and

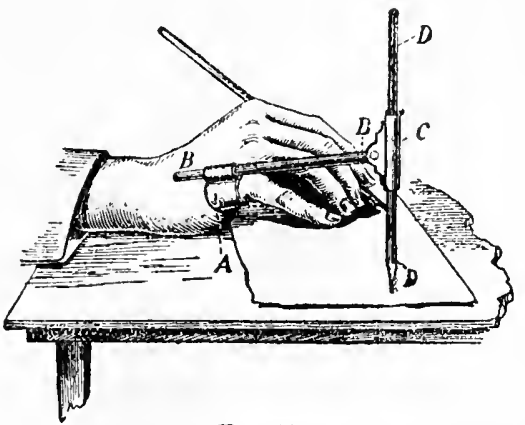

Fig. 14.

arm movements, exeept such hand and arm movements as are made during the intervals between words, when, of eourse, the writing pen is raised from the paper. The tracer-pencil is kept by its own weight eonstantly on the paper, and records all that the hand and arm do, but nothing of the pure finger movements. By a comparison of the written letters and the tracerrecord we can therefore easily determine what part of the whole work is done by the arm and hand and what part is done by the fingers.

A large number of records liave been taken by means of sueh a traeer. Many of them were made by teachers, so that we may use the results directly in our study. Of eourse your individual record would not be exactly like any one of the reeords whieh I have to show. But out of the many records which I have taken, I have 
selected examples which seem to illustrate the gencral types of handwriting, and so your general type of writing is doubtless here represented.

The first typical record which we shall takc up for detailed study is shown in Fig. 15. The letters written

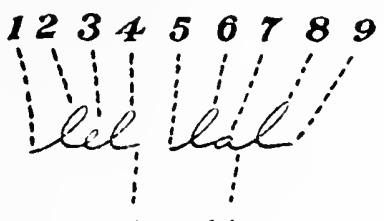

1011

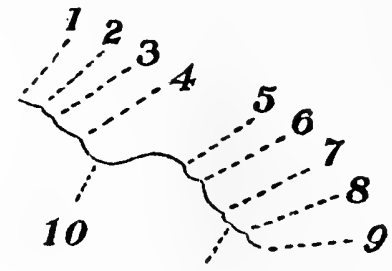

11

Fig. 15.

appear on the left, and the tracer-record on the right. The points which correspond to each other in the two parts of the figure arc similarly numbered. The most obvious fact is that the hand participated only in the forward morements, while the fingers did all of the finer work in forming the letters. Thus, the lines between 1 and 3 in the tracer-record represent the wholc movement of the hand during the writing of the lctter $l$ and the first stroke of the letter $e$. A still more striking illustration of the relation between hand movements and finger movements is found in the case of the letter $a$. From 6 to 8 in the tracer-record, we have the total movement of the hand from the top of $l$ to the top of the next succeeding $l$. The movcment $6-7$ in the tracer-record, represents the part played by the hand in making the downward stroke of the $l$ and in carrying the fingers forward to the position from which they did the larger part of the work of forming the $a$. If 
6-7 is contrasted with $2-3$, which represents a similar movement from the top of an $l$ to the top of its next succeeding letter, which was in that case $e$, a very characteristic fact in all hand movements will be observed. It is the fact that in most cases the hand does its part in the formation of a letter before the fingers begin their finer formative work. Coming back now to the $a$, we see that after making the long movement $6-7$, the hand participated in the completion of the $a$ only to the extent indicated by the line $7-11$. The point 11 is somcwhat less definite in its location than are the other points, and is consequently indicated below, rather than above the line.

Another important fcature of this tracer-record appears in the differences in slope of the three parts 1-10, 10-5, and 5-9. The part 1-10 indicates the movement of the hand during the writing of the first group of letters. Its slope indicates that the hand executed a considerable movement from left to right on its own center in the wrist. During the pause between the writing of the two groups of letters, an entirely different form of movement was executed, as is shown by the new slope in the line 10-5. In the first place, the slope indicates that this movement was made from an entirely different center. It was indeed an arm movement centered at the elbow, instead of at the wrist, as was the movement 1-10. But it also included a wrist movement from right to left, as is indicated by the convex form of the line just before 5 . The interval between the groups of letters was, accordingly, employed in executing an arm movement which carried the hand forward, and in executing a backward wrist 
movement whieh prepared the hand for the new series of forward movements which we find reeorded from 5-9. This new series was made up again of wrist movements from left to right.

Fig. 16, from a different writer, presents a somewhat different type of coordination. Here the hand

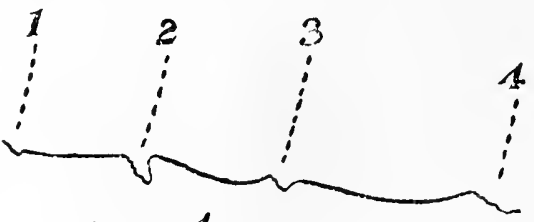

1

cene
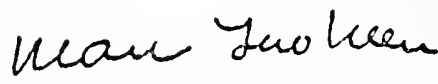

FIa. 16.

movement during the writing of the letter was mueh less than in the ease of the first subject. The arm movements were longer and freer. The hand and fingers were earried forward by the arm during the intervals between words, to positions eorresponding to the middle of the word to be written, and then the fingers exeeuted the major part of the writing movement.

This is, beeause of the limited amount of hand movement, a very exeellent illustration of the relation of hand movement to the word. Any group of letters whieh is written with a single progressive hand movement, as were these groups in the figure, will be seen to have a kind of unity whieh ean not be overlooked. It is not the unity of a single letter, to be sure, but it is a higher form of complex unity. It should be noted also that such hand movement units are not always' co- 
extensive with single words. A long, complex word is often broken up into two, or even three, such hand morement units with a regular arm movement between. Sometimes, on the other hand, two short words are united into a single continuous phrase and are written with a single unitary hand movement.

Records essentially identical with the one reproduced in Fig. 16 wcre secured from a number of persons who wrote "round" letters, and from every case investigated in which the writing was of the type known as vertical. There is, accordingly, ground, as far as these cases are concerned, for the statement that broad, round letters, indicate a preponderance of finger movement.

While the relative importance of the various movements is different in the cases reproduced in Figs. 15 and 16 , yet the same general statement which was made in the analysis of Fig. 15 can be repcated for Fig. 16: the function of the hand is to participate only in the forward movements, while the fingers do the work of constructing the letters, and the arm acts chicfly in the intervals between words in such a way as to carry the hand forward. It is only neccssary to note that in this second case special emphasis is given to the constructive finger movements which have a relatively larger part to perform than they had in the first case.

A third type of record is reproduced in Fig. $1 \%$ This record shows a very pronounced preponderance of arm movements. The movements recorded in 1-6 and 7-11 differ little in slope from the recognized arm record between 6 and $\%$. The hand reproduces the letters in much more detail than in the other cases, because 
it is carried along in the process of writing by a general arm movement. To be sure, the finer details of the letters are here, as before, formed by the fingers, but there is more of the general work done by the hand, and arm muscles. The writing here reproduced is obviously bolder and more angular than that in the earlier records. This writing is typical of a whole group of cases
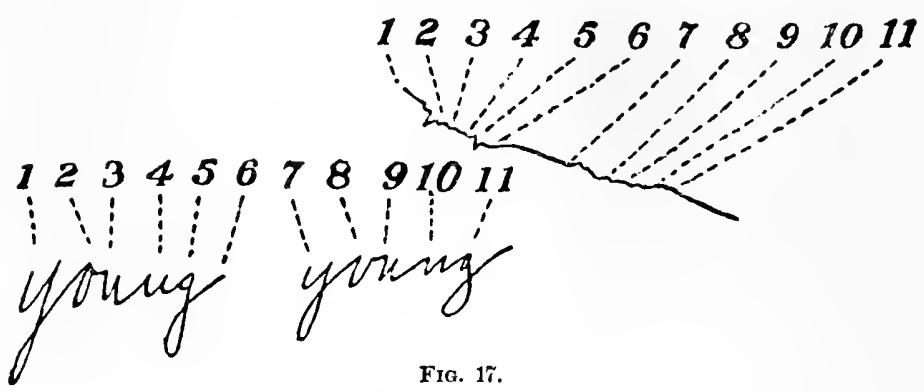

FIG. 1\%.

in which the morement is coarse and more general, and in which less attention is given by the writer to questions of form.

It remains for us to notice that there are certain forms of writing in which the individual has trained himself to make no use whatever of the fingers. It is not our purpose at this time to deal with such unusual and extreme forms of writing movement. Enough to say that they require long periods of special practise. When the ordinary individual is asked to write without moving the fingers, the records generally make it very clear that some finger movement has crept in, in spite of the effort to exclude it.

The general conclusion from the comparison of a large number of records, of which the three reproduced 
represent the chief types, may be summed up briefly in the statement: in ordinary writing the fine formative movements are executed by the fingers; the movements which carry the fingers forward are executed by the hand or arm; and the pauses between groups of letters are utilized for longer forward arm movements which bring the hand back into an easy working position.

The different types of coordination are well illustrated in these three records. Let me repeat the statement that each individual has his own peculiar combination of arm and hand and finger movements so that while these three records represent types, they do not by any means represent all possible forms of coordination. The forms of coordination are as numerous and as various as are the individuals who write.

Let us carry the experiment further so as to see what are some of the influences which effect even a well-established habit of movement. A subject was required to make a record of a series of free upward and
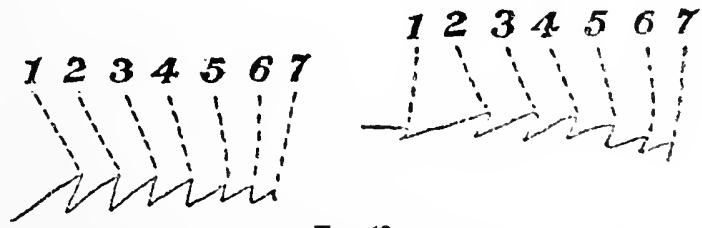

Fig. 18.

downward movements such as those represented on the left of Fig. 18. In this first experiment no restrictions whatever were placed upon the subject; he was allowed to make each line in the freest possible manner. The 
corresponding tracer-record is given on the right of the same figure. The presence of some finger movements appears in the fact that there is a lack of sharply defined angles in the tracer-record. The tracer-record shows, however, by its general form and slope, that it is due very largely to free arm movements which carried the whole hand over the same path as that traversed by the writing pen.

The lines which the subject had prepared in this first free drawing were then set for imitation, and in order that the imitation might be exact, the extremities of each of the upward and downward novements were indicated before the movement began by means of dots. A typical result of such restricted morement is presented in Fig. 19. It should be noted
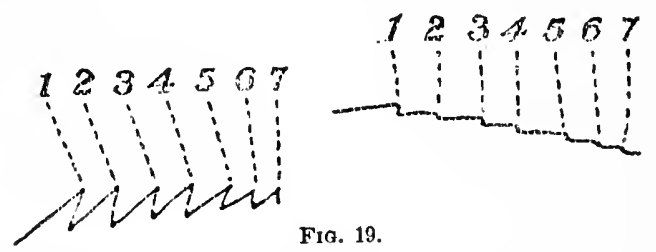

Fia. 19.

also that the time required for such restricted morement was decidedly longer than that required for the first free movement represented in Fig. 18. The characteristic difference between these two movements is, of course, obvious when the two tracer-records are compared. The first or free movement is predominantly an arm morement, the second contains a very much larger clement of finger movement, especially in the downward strokes. The subject finds that in order to meet the points prescribed, it is necessary to make a fincr, 
more accurate adjustment than was necessary in the first drawing.

A fact which appears very clearly in Fig. 18 may also be nuade a subject of special comment. The movement is not the same in character at the outset as it is later in the course of the drawing. This same fact appears in almost every record of writing. The hand is.evidently not in position at first, but requires a few strokes to adjust itself. Sometimes the necessary adjustment is brought about by a greater emphasis on finger movement, sometimes by a more pronounced hand movement.

Another group of results is as follows: Any change in the conditions under which the subject writes will modify the character of coordination. A change from a hard pencil to a soft pencil, or a change from a vertical position of the paper to an oblique position, will be sufficient to produce noticeable variations in the character of the muscular coordination, even when the product of the movement--that is, the written lettersconform very closely to the same type.

There is one movement which enters into the total complex of writing movements which requires special attention. It is not recorded by our trácer and consequently must be studied by itself. It is a movement which the physiologists describe by the name pronation. It consists in rotating the hand, so that it tends to lie flat on its palm. This rotary movement is possible, as you know, because the lower arm is supplied with two bones-the ulna and radius-which fasten at the wrist in such a way that they can turn the hand so that the palm lies either upward or down- 
ward. When the palm is downward, or prone, the position is due to the movement which we mentioned, the movement of

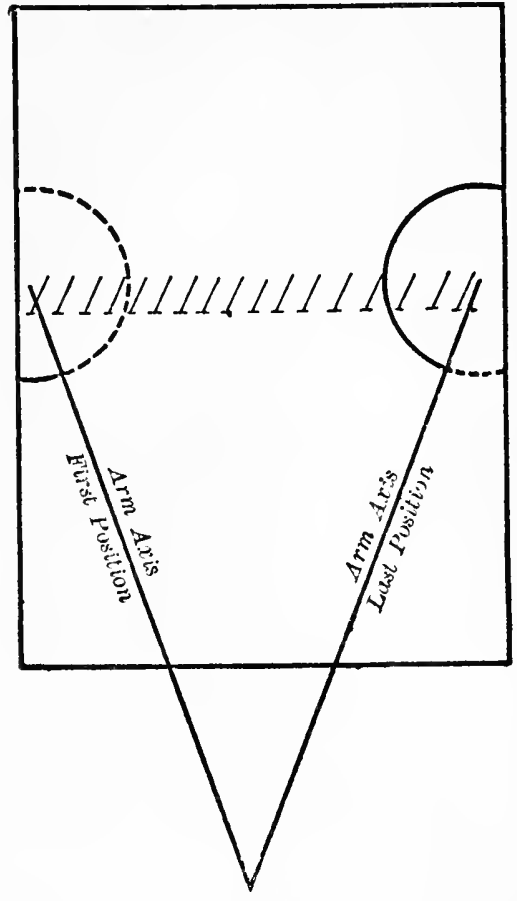

Fra. 20. pronation. Most adults make a slight movement of pronation in the course of writing a line across the page. The motive and effect of this movement can be easily understood. Let us first note that the position of the hand and fingers at the beginning of the line of writing is such that the movement of the first finger (which, as we have seen, is the most important movement in directing the pen in its downward strokes) will give the letters a certain slope with reference to the edges of the paper. This first slope may bc to the right, or it may be vertical, or it may be to the left; but in any case it is the result of a pen movement which depends for its direction upon the total position of the hand, arm, and fingers, with respect to the edges 
of the paper. As the hand moves across the paper during the writing of the line, it is obvious that the position of the arm and hand with respect to the paper must undergo a change by virtue of the movement of the arm about its center in the elbow. To makc this statement definite we may study the angles with the aid of Fig. 20, and we shall find that the angles formed by the axis of the arm and the left edgc of the paper are, at the beginning of the line, acute below the point of intersection and obtuse above; while the angles formed by the axis of the arm and the edge of the paper, at the end of the line of writing, either are, or tend to be, just the rcverse. If as sometimes happens the center of arm movement-that is, the elbow-is itself moved forward during the writing of the line, the above statement in regard to angles holds with this change: each period betwcen movements of the elbow is to be treated as if it were a scparate line.

The gradual modification in the position of the arm axis with reference to the edge of the paper, which takes place during the writing of a line, requires some definite form of compensating movement, if the slope of the lctters is to be kept uniform with reference to the edges of the paper.

It should be noted at this point that a compensating movement of less degree is required to counteract the changes in the direction of the axis of the hand which are due to the wrist movements that take place as we have seen in writing a word (sce Fig. 15, p. 172). This lesser corrective movement is of the same type as the greater movement which is the main subject of discussion; it therefore needs no special discussion. An- 
other preliminary remark is that if one examines many specimens of handwriting, he will see that only partial corrections of the slope of finger movements have usually been effected by ordinary writers. The slopes of letters at the end of a line, and the slopes of letters at the end of a word, are commonly greater than the slopes at the beginning. This failure to correct the slope, gives to the line and to the word, the somewhat irregular appearance usually noticeable in ordinary writing.

Coming back to our main discussion, we may say that, so far as any correction in slope is effected, this correction results from a movement of pronation which tends to throw the upper end of the pen toward the writer and thus to give the pen a movement more nearly parallel to its first movements at the beginning of the line. This movement of pronation is one which most adults have, but have in only partially developed degree. It is a kind of added refinement which gives uniformity to the slope without interfering with the continuous arm movement across the page. If the movement of pronation is present only in small degree, another way of securing uniformity of slope is to keep moving the elbow forward every time the slope of the letters begins to grow noticeably different. This repeated change of position of the elbows is, howerer, neither easy nor conducive to fluency of writing.

The corrective movement of pronation which we have been discussing, is required no matter what the slope of the letters. It is not a factor which will help to settle any of the disputed questions in regard to the slope of writing, it is rather a factor of movement 
necessary to secure uniformity, whatever the slope. It is one of the nicest refinements of the whole complex coordination, and when fully developed it can be observed as a regular and very gradual adjustment as the hand travels across the page.

This movement of pronation furnishes a favorable subject for investigation, just because of its incomplete development in most adults. A group of ten teachers was once induced by the present writer to give some attention to the regularity of the slope of their letters. The niembers of this group were asked to pay attention as closely as possible to the conscious processes which accompanied their efforts to improve, and they were also asked to make daily records of their observations and to note whether or not they really improved in the regularity of slope during the period of practise. These ten teachers were all trained in careful observation and could consequently be depended upon to take up the practise with intelligent interest. On the other hand, they had no special preparation for the particular form of practise which was prescribed. No one directed their attention during the first period of the experiment to the movement of pronation, and they were asked to put themselves as far as possible in the normal attitude of one who is trying as earnestly as possible to improve his writing, rather than in the studied attitude of one who is investigating the problem merely as an outsider.

The first result of the practise was that each of the persons became clearly conscious of the fact that his own writing contained many irregular slopes. Attention to this matter grew so keen that it extended to 


\section{GENETIC PSYCHOLOGY FOR TEACHERS}

the writing produced by others, and all the observers expressed surprise at the degree of irregularity that had, up to this time, escaped notice. There was a very general agrcement that the recognition of this irrcgularity of slope was a definite experience resulting from an unusual and clearly conscious comparison of the forms of all letters looked at by the experimenters.

As soon as the irregularities were recognized, and the effort to correct these irregularities commenced, there was a general agreement as to the difficulty of finding any guiding slope to follow in actual writing. The effort to refer back to earlier letters in a given line, the effort to refer to letters in the line above, the effort to carry in memory a sort of standard angle with the horizontal line-all these devices are mentioned as methods of securing uniformity. There is not a single case among the early records of the ten adults in which refcrence of any kind is made to any form of movement. All the devices mentioned emphasize the visual guides as the ones consciously employed. Several noted the tendency to write more slowly and carefully, and one noted later that it cramped his hand to write regularly. All found it possible to improve the slope of the letters by constant attention. Scveral noted that there were days when the letters were very much less regular than on other days. Many times the days of irregular movements were described in terms which indicated that the physical condition of the writer was not good, but not infrequently the records merely remarked that there was no apparent reason.

Nothing could be more obvious from the records than the fact that the whole practise of these persons 
consisted in what we have called a non-rational effort to approach an end which was always presented to consciousness in terms of visual perception, and never presented in terms of the movements which were the real means by which the end must be reached. The movements were hardly more intelligently or directly guided than are those of a child. The whole attention was concentrated on the product.

After practise had been going on for four weeks with some evidences of improvement, but no definite notion on the part of the practisers as to how they might accelerate the improvement, they were all asked to write under observation a single word at the beginning of the line and then to pass over the middle of the paper to the extreme end of the line and there to write the same word again. The word "long" was used for this test, this being a suitable word to emphasize the slope both above and below the line.

Thrce distinct types of results showed themselves in this experiment. First, there were two cases in which the elbow and whole arm were carried across the page in such a way that the arm was, at the end of the line, in a position parallel to its first position. For these two subjects, the conscious control of the slope consisted, as throughout the practise, in a simple visual recognition of the slope of the letters produced. They could not even describe their movement when asked to do so. Secondly, there were three distinct cases in which the hand was adjusted by a movement of pronation, such as that described. But even in these cases the movement was present in such a completely automatic form that it attracted no attention 
to itself. Finally, the remaining five members of the group fall into a elass intermediate to the first two elasses mentioned. For these five experimenters, the movement was not purely automatic nor could it be described as wholly developed. When these writers reached the end of the line they found the hand in such a position that it was impossible to make a slope that satisfied their visual expectation without executing some kind of additional movement. The movements employed were of various kinds, but usually contained an element of pronation. The pronounced demand for a change in the position of the hand called attention to the hand itself. It is to be noted at once, however, that no one of the subjects paid attention to the hand any further than to try to get the fingers into an easy position. There was no disposition to make the hand the chief factor in attention. So long as the hand could not be used readily in produeing the slope desired, there was a recognized demand that it be moved. The movement was of a tentative and non-rational kind, now in this direction, now in that. There was no distinct and clear recognition of the position aimed at, nor of the superiority of one kind of movement over any other. There was merely an effort to reach a certain end of production, and in order to reach this end, the hand had to be in an easy position, and it was moved until brought into this easy position. That attention to the hand was not of clearly recognized importance in developing the right form of action, appears in the fact that there was no uniformity in action even after some of the subjects had by chance hit upon the easy movement of pronation. They eontinued, time after time, 
to find it necessary to makc tentative efforts in this direction and in that, until finally the proper movement was hit upon by what seemed in each case to be pure chance. No one of the subjects ever discovered the movement itself in any such way as to call attention to it as a fact of movement. In other words, the position of the hand was never clearly recognized in terms of its own movements. Consciousness on the part of these writers was always visual consciousness. Movements were not subjects of direct attention, and they wcre never held in consciousness in the form of memories of clearly recognized movements.

Here, then, is a splendid example of how, through one's own training, one may learn what are the difficulties in the educational process. Writing, which is essentially a coordinated movement, has to be developed through trial after trial, with consciousness directed, not upon the movement itself, but on the visual images which appear as results of the movement. What onc is training is the movement; what one is thinking of is not movement at all, but visual images. When the movement becomes well enough trained so that onc need not have any anxiety about its operating wcll, then attention is withdrawn in great measure from even the visual forms. Attention thus becomes free in the last stages of development to rcach out into wider ficlds-that is, to leave even visual experience-and devote itself to the meanings of words and sentences.

The final result of the completc development of the writing habit is that the movement thus becomes wholly automatic. This automatic character of adult writing is one of its most interesting and significant charac- 
teristies. Beeause the habit is so thoroughly automatie, we do not recognize it in ordinary experience as a subjeet worthy of study. We eome to think of it as we do of a hundred other automatic habits-as a natural endowment. Of eourse it is not a natural endowment. More than most of our highly developed habits, more than walking or talking, for example, writing has beeome automatie through individual praetise.

Walking espeeially is a form of museular coordination for whieh the nervous organization was largely provided in the brain of the infant when the infant was born. To be sure, it took some time after birth for the walking center to mature, but it was all provided for, and needed only to grow to its full maturity. But writing was provided for in the infant brain only in the general sense in which there are unorganized eenters ready for development through individual praetise. That this unorganized writing eenter beeomes a fully developed eenter of museular coordination, that we have in adult life a eompletely automatie habit of action in which attention is freed even from visual control of the movements, is an indieation of how much individual practise ean do to develop movement even when praetise operates, as we know it does in this ease, without attention to the movement itself.

It remains for us to beeome somewhat more fully aequainted with the meaning of the statement that writing is automatie. Let us begin with a deseription of the faets of experienee. We sit down and think out the thought, and then the rest of the process goes on very easily, occupying a little time, to be sure, and 
requiring some little directing attention, but making no heavy drain upon consciousness. So slight, indeed, is the attention devoted to the writing process after the thought has been clearly worked out, that one finds himself making all sorts of curious slips. One finds himself writing the for they, as though the word having been once thought out, consciousness hurried on to the next word and did not notice in its haste that sufficient time was not allowed for the execution of the first order. Or the fact that consciousness is far beyond the laggard movement of writing appears in the mistaken ending which is added to a given word and is obviously borrowed from some word farther on in the sentence. I find illustrations of this in my own manuscript where I have written "in favoring" in the phrase "in favor of their learning," or where I have written "broal" in the phrase "broad and liberal." Again, one sees how little consciousness watches over the developed writing movement when some wholly undesired word is written instead of the one thought. Thus, one writes "is" for "if," "from" for "for," and less frequently makes such substitutions as the following, borrowed from a letter now on my desk, "shall" for "sound." Here the first letter of the word being well under way, the attention of the writer evidently left the movement to finish itself automatically. The writing habit is so thoroughly organized that for the most part it can be relied upon to do what is appropriate. These mistakes which show how far the movement may go wrong, give us a notion of how thoroughly we rely, in all cases, upon the organized movement to go on without watching. 
Another way of realizing how thoroughly automatic the writing movement has become in adult life, is to contrast the easy flow of thought that one enjoys when all is well with the writing-as, for cxample, when one is using a good pen-with the utter impossibility of doing anything in the way of thinking when one is supplied with a poor pen or bad paper. The poor pen kecps consciousness so busy with the mere making of marks that there is no surplus attention to reach out into the realms of thought. Noble sentiments with a bad pen are at least difficult, one is probably justified ill saying they are uttcrly impossible.

The statement that the writing movement requires very littlc attention to itself is an important description of the developed adult mode of writing. But to tell where attention is not concentrated, is a negative statement, and is never complete without its positive supplement. The positive supplementary statement has alrcady bcen more than hinted at in our discussion, but is of sufficient importance to deserve special consideration. The attention freed from concentration upon any phase of the mere act of production, is turned to the thought to be expressed. Writing would not be a means of expression unless it were automatic enough to leave the mind free to arrange its ideas for expression. In adult life we are usually thinking about what we are expressing. In other words, the developed attention is turned away from the process of production, and in very large measure even from the product as it appcars in the written lines, and is concentrated upon what is being cxpressed.

There are some cases, to be sure, in which writing 
is not thus used solely as a means of expression. Then we notice at once a marked change in the character of our experience and in the direction of attention. For example, when one writes copy on the blackboard, he is sure to do something besides express ideas. He tries to make unusually regular lines and perfectly symmetrical letters. The thought which the word expresses is not uppermost in the mind. It is well to consider carefully the fact that such copy writing is not writing for expression, but is rather writing for beauty and regularity of form. Attention is brought back in such cases to the process of production, and the writing activity is not automatic.

Sometimes one withdraws attention from the process of production at a stage of development at which it is at least doubtful whether one ought to trust the process of morement to take care of itself. We have already indicated some such cases in our earlier discussions. Thus, the process of writing is usually not sufficiently developed in adult life to ensure regularity in the slope of writing. Most of us do not care to bother, however, with the labor of improving in this particular, and so it comes that long before the refined movement of pronation which we have described, is anything like completely developed, we withdraw attention from the process of getting uniform slopes and turn to the ideas which we are expressing. The first step, if one would improve the slope of his letters, is to go back to the stage of development in which attention is turned to the process of production. As we saw in the cases described, the first step toward im. provement in slope is to attend to slope. 
This study of adult writing marks out for us the problems which must be taken up when one attempts to investigate the development of writing in immature writers. There are two entirely distinct problems of development. One problem is to discover the character and degree of the muscular coordination involved at different stages of development, and the other problem is to discover the direction and object of attention. The one problem consists in the analysis of the movement into its factors, and in the intelligent understanding of the way in which these movement factors cooperate in the unitary and yet complex form of action under discussion. The other problem is the problem of the conscious states parallel to the physical movements.

And now our examination of the teacher's process of writing is complete, at least as far as we can carry it here. We find writing to be an automatic form of production in which all one's past development is expressed in one's own individual mode of coordination. Let us ask some of the questions that are so often asked in the discussion of writing. First, what is the most approved form of movement? Second, how shall one hold the pen, keeping in mind the fact that its angle to the paper must be changed as the hand moves across the paper? Third, how shall one hold the hand? Fourth, how shall one place the paper? Fifth, shall one make the letters round or long; and at what slope shall the letters stand? Sixth, what is the normal speed of writing? Seventh, what is the normal age at which automatic writing is attained? Do you not see that these questions can not be answered without very large con- 
sideration of the individual? You are not dealing, let me repeat it, merely with pens and paper when we take up these questions. You are not dealing primarily with forms and letters; you are dealing with some individual's muscular coordinations and with some individual's conscious processes of attention. I should rather see the writing teachers of this country intelligently interested in the development of this or that child; I should rather see them engaged in the careful study of the particular form of coordination that has been attained at any given stage of development; I should rather see them interested in the necessity of turning the attention of the individual child in this direction or in that-than to see them interested, as they now too often are, in all the systems of writing that can be invented. How often those who have given any attention to the writing taught in the schools have seen the same system successful in one class room and utterly unsuccessful in the next room. Why is this? The explanation is to be found in the difference between the teachers. Some teachers recognize even now that the child is the important center of intercst during the writing lesson. Such teachers are on the right road. Let us follow their lead, striving only to extend our knowledge of the writing process beyond what is known at the present time.

The question is seriously asked again and again in these times: "Shall teachers be investigators?" And the wail of the overworked teacher is heard answering this question in the negative. I think that we have too often been misunderstanding what investigation means. We have been led to think that it means in- 
quiring into matters outside of our practical workthat it means leaving untouched the matters that lie at our very hands. Of course you will be overburdened if you investigate some remote corner of the globe and then clumsily blunder with the processes of every-day school life. Will you not see that you should revise your notions of what investigation is? Will you not take up some investigation which fits your work? Make your investigation relevant, and then it will not overburden you. On the contrary, it will lighten your task.

What investigations are relcvant, do you ask? I think there can be no difficulty in answering that. Study to understand the common forms of bodily and mental activity with which the school deals. Study yourselves and study the children. It will profit you more to know all about what you do when you write, and all about what your children are doing when they learn to write, than it will to know about some of the remoter phases of mental or physical life. The truth is that we are not quick to see the value of studying commonplace facts. We want something striking. We study children's preferences for colors, and children's secret languages, and what not, and we find their everyday commonplace activities with which we have to deal in our routine lives entirely escaping us. Or we try to answer some profound question about the nature of attention or memory, or about the forms of reasoning or the categories of thought. Give up all that for the time being. There are problems without number to be solved here at our very hands. They are the direct problems, the productive problems that we need to 
solve for the sake of our own activities. Let us try to solve them first, and then I am disposed to think that most of the others will disappear.

As we bring this chapter to a close, let us review briefly the ground we have covered. Writing is a complex movement. Its complexity is of the harmonious type which results from thoroughgoing cooperation of the various muscles. This cooperation is brought about through the development of a coordinating center in the nervous system. Individual coordinations exhibit certain typical differences which show that the whole problem of writing is one of individual eoordination. The mental processes which parallel the development of muscular coordination may be described by pointing out that when coordination is complete the attention is freed from the producing process and may be devoted to the thoughts expressed. The direction in whieh attention is turned before writing becomes automatic is clearly indicated by observations which any one can easily make if he will try to develop some relatively undereloped phase of his own writing-as, for example, the regularity of the slope of his letters. Such an effort to develop regularity of slope will show that attention in non-automatic writing is centered chiefly on the visual results, and on certain visual eopies.

The aequaintance we have eultivated with the writing process as it is exhibited in ourselves will make it possible in our next chapter to take up a number of questions in regard to the development of the writing habit in others, especially in children. These studies of the development of the habit in others belong to our 
teacher-study as legitimate lines of supplementary investigation, and they will serve also to illustrate the unity in spirit which exists between our point of view of self-examination and the point of view of the true child-study, which is the study of growing faculties. 


\section{CHAPTER VII}

\section{RACIAL AND INDIVIDUAL DEVELOPMENT IN WRITING}

A GOoD deal has been said and written about the parallclism between the development of the raee and the development of the individual. Indeed, it has sometimes been argued that beeause therc is sueh a parallelism, we may safely follow the history of the raee in arranging the eonditions with whieh to surround the developing ehild. This direet application of raeial eonditions to individual life is, however, out of harmony with the fundamental idea of adaptation as we have already studied it in our discussion of the meaning of development. The modern child has before him the problem of fitting himself to the modern, and futurc environment. He will never be placed in the same environment as was his savage aneestors, and it is a great mistake to drag him baek to that primitive environment in the hope of adapting him in that way to the highly complex and highly developed eonditions of life which really eonfront him.

I have made this prefatory statement in the hope of preparing your minds in a negative, as well as in a positive way for the disellssion whieh we have now to take up, for we shall begin our discussion of the way in which the writing habit develops, with an outline of 
the way in which the race has developed the ability to write. Then we shall trace the parallelism between this general racial development and individual development. And I warn you again that the parallelism is not directly productive in the sense of giving us methods or devices that can be taken up in immediate pedagogical practise. For example, as we go back to the days when men wrote with pictures only, do not begin to think that the child of to-day would profit by a similar ordeal of picture-writing before he attains to symbolwriting. That is not the value of the parallel. The real value of the parallel lies in the fact that in the history of the race's struggle we have a long and complete record of how the human mind and the human hand have, under comparatively simple conditions, grown more and more skilful in this particular art. Having learned in this way something of the principles which underlie this art, something of its aims and purposes as revealed in its development under simple and diverse conditions, we can better attack the much more complex problem of the modern child learning to write under more complex and stable conditions. The development of this individual child will certainly not be the same as that of the race, for the child does not have to develop a system of writing. He has merely to learn what the race has prepared for him to use.

By way of positive statement, we may say that where the child differs from the race we shall look for differences in the conditions surrounding the two processes of development. Where, on the contrary, the motives and tendencies of development are dependent on characteristics of the mind or hand rather than upon vari- 
able external conditions, we shall gain from our study of racial development eertain positive suggestions about the character of the child's development, in spite of the different ways in which these motives and tendencies actually manifest themselves in the two cases. Our study of the parallel ean thus be made productive without our being misled into any effort to find direct applicability of racial history to the work of the school, or without our losing sight for a moment of the fundamental differences as well as the fundamental likenesses between raeial and individual development.

The most primitive writing was of the kind which all of you have seen represented in our histories, where they describe the savage condition and early writing of the American Indians. A specimen of such writing is given in Fig. 21. Sueh writing always eonsists in a few rough pictures. There was evidently little ability to make fine, regular lines. The writer's museles were not trained for delicate work. There was not even a clear and fully matured reeognition of the form of the objects presented. No details were present, and the whole picture was a sort of rough approximation to the original. But rough and crude as these drawings were, they appealed to the savage's nemory and imagination enough to eommunicate to hin certain ideas. What could be more natural than that these lines and figures intended for the eyes, should reproduce that aspect of objects which appealed to the eyes, namely, the form? This primitive writing was, all through, a matter of visual interest and visual recognition. Its purpose was to communicate ideas as elearly and as accurately as possible by an appeal to the eye. 
Starting from this primitive picture-writing, human development runs out in two different directions. In the first place, men began to take more and more interest in the reproduction of form. The details of the
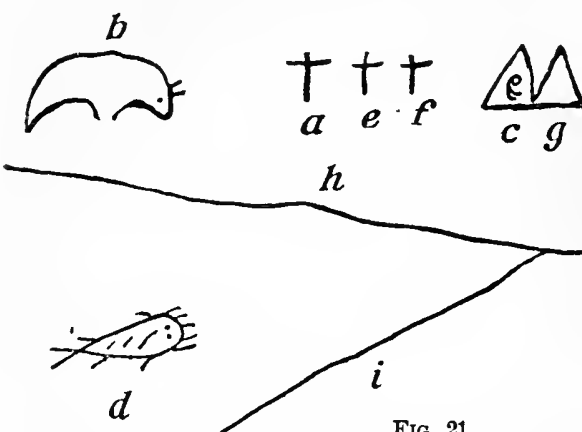

An Ojibwa love-letter, recorded and explained by Garrick Mrallery in the Annual Report of the Bureau of Ethnology, 1888-'89, p. 363. The writer, a girl of the Bear totem (b), summons her lover, who belongs to the Mud Puppy totem (d), along the various trails indicated, to the lodge $(c)$ from which the beckoning hand protrudes. The enclosed figures at $l, j$, and $k$ are lakes. The crosses indicate that the girl and her companions are Christians. "The clear indications of locality," writes Nallery, "serve as well as if in a city a young woman had scnt an invitation to her young man to call at a certain strect and number."

original objects began to receive more attention and to be more accurately and fully incorporated into the reproductions. This refinement of form very soon began to go beyond the limits necessary for the communication of ideas, and an art developed whose chief interest is the higher and higher treatment of form. This art which deals with form appeared at first as drawing, later as sculpture and painting. In these 
various branches of what we call art in the narrower sense of the term, the direct appeal to the eye is continued and brought to its highest perfection.

The second line of development, which begins with primitive picture-writing, is the one in which we are interested in our present discussion. It is the line of development of writing proper. Here we must recognize a greater devotion than in art to the desire to communicate ideas. The form of the figures used in writing is of interest only in so far as form stands for some kind of meaning. The result of this chief interest in meaning rather than form is that the forms are reduced to their simplest terms. There is, indeed, a point beyond which the form can not be simplified without danger that it lose its power of communicating a distinct idea. Thus, if the savage wishes to make a distinction between horses and cattle, he must keep enough of the distinctive details to insure the communication of the right idea. He accomplishes his end in this particular case by retaining the horns as the distinctive mark of his drawing for cattle. But while form can not be lost sight of entirely, it is so unimportant that purely external causes may contribute to the corruption and simplification of the forms of the drawings. Thus, one such outside consideration is to be found in the fact that straight lines are easier to draw than curved lines in the kinds of materials frequently used for early written records. The result is that not only were forms much simplified in the early stages of writing, but they were simplified in Egypt and Greece and in many other primitive civilizations, so as to be more easily engraved on stone and metal or other inflexible materials. 
Some exeellent illustrations of corruptions in form are given to us by students of Chinese writing. Chinese writing, as you may know, is not like our own, made up of a few elements. It has a separate symbol for eaeh word. The word for sun, for example, is a single symbol rather than a series of three letters as in our writing. The modern Chinese symbol for sun looks like a ladder with three rounds. At first sight this does not seem to lave any relation so far as its form is concerned to the objeet for whieh it stands. But compare this modern symbol with another symbol of more ancient origin and the meaning is elear and the modification in form is immediately reeognized as due to the general prineiple that straight lines are easier to draw with the brush-pen of the Chinese than are curved lines. The aneient form for the sun is a pieture, eonsisting of a cirele with a dot in the eenter. The dot of the aneient symbol is the middle round of the modern ladder-shaped symbol. The sides, and the top and bottom rounds of the modern figure, are the final rectilinear remains of the eircumferenee of the ancient circle.

Fig. 22 reproduces a number of ancient and modern Chinese forms which bear out the same eonclusions as those reached in the ease of the first symbol for the sun.

Form-writing thus developed gradually into what might be called convenient or simplified form-writing. The convenient writing would not have been possible unless there had been the aeeompanying mental development away from the form to the meaning. This latter fact of greater and greater emphasis on mean- 
ing rather than form, makes the characters used in the writing symbolic in their use, and so we refer to such writing as symbolie writing. Finally, we must not lose sight of the fact that even in this symbolic stage, the
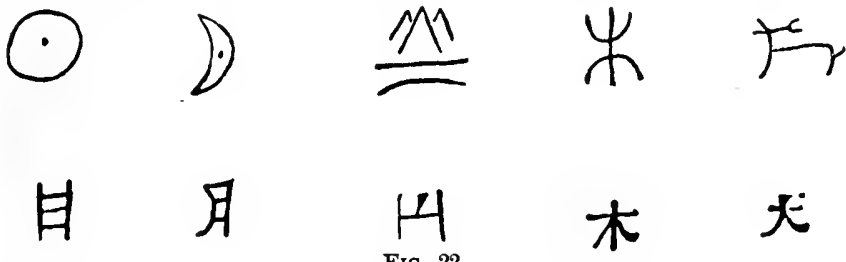

The upper line shows ancient forms of Chinese writing, the lower line shows the derived modern forms. The characters signify, reading from left to right: sun, moon, mountain, tree (or wood), dog.

imagination of the reader or writer is aroused direetly through the eye. The visual symbol means a visual object, so that these written reeords constitute a series of purely visual experiences.

The symbolic attitude, or the attitude in which meanings are more attended to than forms, makes possible a wide range for development. Symbols freed from any direet referenees to objeets of like form, eame very soon to have two or three meanings, some very remote from the original signification. Thus, in Egypt the figure of the owl eame to mean, not only the bird itself, but also, as with us, night, and still more indirectly, wisdom. Among our American Indians, the animal which the Indian ehief painted on his totem pole came to stand for the man, and sometimes for the whole tribe. Symbolism of a highly developed type thus beeame eommon. 
At this point therc set in another line of development which was slowly worked out in Egypt and Phenicia, and which has liad the greatest possible influence on the development of our present form of writing. As soon as form symbolism had reached a high development, it naturally came into contact with another symbolical mode of representing objects which the race had developed. This other mode of representing objects by something quite different from the objects themselves, is what we call speech. It needs no long discussion to bring to your minds a clear recognition of the fact that speech is a kind of symbolism. A given sound arouses in the imagination an idea which is quite rcmote from the sound itself. To make this step in the development of writing somcwhat clearer, let us put it thus. Here is a given object. When the primitive man looked at that object he received a direct impression. If, now, after having received a direct impression, he wished to arouse in a companion a recollection of such a direct experience, he could do it in one of two ways, either by making a symbolic mark or by making a symbolic sound. The symbolic mark and the symbolic sound had at first no connection exccpt as they both referred to the samc object. But very soon the sound symbolism began to assert its superiority. The sound name of an object was so fully developed and so thoroughly familiar that it took precedence as the means of expressing thought. Men did not even stop to recall in full the direct impression made by the sight of the object. They began to do as we do, to think in words, and to let the objective appearances drop into the background. And just as soon as this hap- 
pened, the written symbol was forced into relations with the sound symbol.

The first steps of this growing relation between sound and written symbols were of a type with which we are all quite familiar. You all know the kind of puzzle called a rebus, in which the first personal pronoun I, for example, is represented by a picture of the organ of sight, which has a name similar in sound. The verb " can" may likewise be represented in a rebus by that convenient tin article of household furniture with which we are familiar. We are thus well on the way to a sentence. "I can see a house," for example, would be easily completed in the same general way so far as the verb " see" is concerned by a picture or symbol of the ocean; and then all we need for the house is a true written symbol of the house itself.

Now this kind of rebus-writing actually appears in some of the old Egyptian records, to show us how sounds and written symbols began to be related. Thus, the Egyptians had a word, the name of one of thcir gods, which was pronounced Hesiri. They also had two distinct words, hes and iri, exactly like the two syllables of the name Ifesiri, so far as the sounds wcre concerned, but in no way related in meaning to the name of this god. The two separate words, hes and iri, mean, respectively, a seat and an eye. When they wanted to write the name of the god, they did not draw his picture, but they evidently thought of his name, and then, thinking of the sounds only, they made this double pun that he was a seat-cye god. After that the representation of the god was easy, for they drew first the seat and then the eye and let it go at that. Another 
illustration from Egypt is the use of a basket to mean lord. This usage is perfeetly elear as soon as we know that the word for basket and the word for lord were both pronouneed neb.

Notice that the written symbol is, by this eonneetion with the sound, given a wider range of usefulness than ever before. The pieture of a basket, for example, came to stand, not only for the basket itself, and for the aet of earrying, and for the idea of plenty, but it eame to stand also, through the assoeiation with sound, for the word lord.

After this form of rebus-writing, the sound assoeiation went forward another step. Instead of using a symbol beeause of the total sound whieh it represented, the symbol began to stand for the first sound contained in its name. Thus, to invent an illustration using our own English words. Suppose one wanted to write the word monkey. This being a rather hard animal to draw, the writer would divide the word into two syllables, and would then look around for some objeet the first syllable of whose name was the same as the first syllable of monkey. Mon is the eommon syllable of the words money and monkey. Use the pieture of a eoin then to stand for the desired syllable mon, and our word monkey is half written. The last part of the word monkey can be easily represented in the simple rebus fashion by a key.

This way of breaking up words so as to extraet the first syllable is a very elumsy deviee, to be sure. We ean hardly understand how the race had ingenuity enough or patience enough to do it. But if you will think a moment you will see that the work of breaking words 
up into constituent sounds had to be done in some such gradual way as this. It is not an easy thing for the child of the prescnt day to break up words with which he is familiar into their constituent sounds. Have you not heard a child saying over words which contain similar sounds with obvious delight at the similarity he has discovered? The pleasure which children get from such combinations as ding-dong, see-saw, is evidently due to the like sounds at the beginning of these syllables, and the intercsting contrast in the later sounds. With such illustrations in mind, it is easy to understand how the old Phenicians gradually, by this comparison between initial syllables, discovered the fundamental sounds and produced a sound alphabet which was capable of expressing all the different possible phonetic variations in their language.

The illustration which we invented of monkey and money is paralleled by real historical facts in abundance. Thus in the ancient Egyptian language the name of the owl began with the sound which we represcnt to-day by the letter M. The Egyptians came to use the owl as a symbol for this $\mathrm{M}$ sound. And as little as one would guess it from the form of our letter M, this letter is the direct historical descendant of the Egyptian symbol of the owl. Fig. 23 will make it clear to you how the line of descent is traced. This series of figures also shows again the fact to which we have already called attention, namely, the fact that as interest in the form of the symbol grows less and less intense, the form will decay and become more and more simple and convenient. It will finally be reduced, as are all our lctters, to comparativcly simple groups of lines, not re- 
sembling even remotely the objects from which the figure was first derived.

Sometimes the historical evidence for this derivation of letters from the first syllable or sound of names, is preserved for us in the names of the letters them-
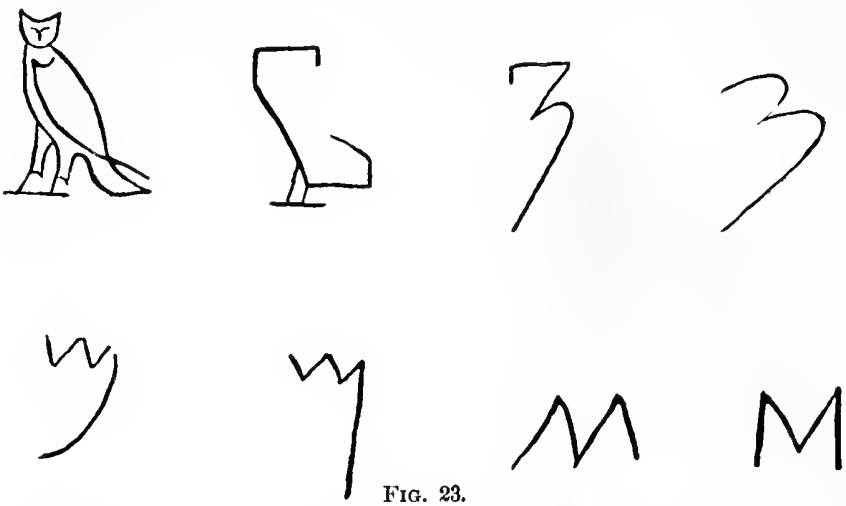

Fig. 23.

The figure shows the derivation of the letter $\mathrm{M}$ from the Egyptian hieroglyphie owl. The four forms in the upper part of the figure are Egyptian forms. The first on the left is the usual hieroglyphie pieture of the owl, or, as it was called in the Egyptian language, mulak. The three remaining upper forms are found in the writings of the Egyptian priests. The first form on the left of the lower series is an aneient Senitic form. Then follow in order an aneient Greek form, and two later Greek forms. (From I. Taylor's The Alphabet, pp. 9 and 10.)

selves. Our own English letters now have names which correspond to the sounds of the letters and these simplified sound names are no longer indicative of the origin of the letters. For significant names we must go back to some of the more ancient alphabets where the letters retain their primitive names. Thus, in the Hebrew 
alphabet the first letter is aleph, and means ox; the second letter is beth, and means house; the third letter (like our English g) is gimel, and means camel; the fourth is daleth, and means door, and so on.

We have now traced the history of writing down to the point at which it begins to be a means of representing sounds rather than direct visual experiences. We should recognize clearly that the primitive attitude of mind was one of attention to form. That the gradual emancipation of attention from form and its transfer to meaning was complicated with the secondary line of development which grew out of the necessity of subjugating written symbolism to the more fully developed sound symbolism of speeeh. All this development was very ancient. The Greeks emerge from their early association with the Oriental world fully equipped with a sound alphabet, which was, doubtless, borro largely from the Phenicians. The Romans learned the same alphabet from their Italian ancestors and later modified it through their own use and through contact with the later Greek forms.

The forms of our own letters are derived in very direct lines of descent from the Roman forms, so that we may confine our attention to the Roman alphabet and the later European alphabets derived from the Roman.

The earliest Roman forms were used on monuments, and owe their form very largely to the hard materials on whieh they were traced. The letters were made up almost entirely of straight lines and sharp angles. They were all very nearly uniform in height, and were written without connections between the suc- 
cessive letters and without breaks between words. Fig. 24 gives an illustration of this earliest type of writing, as used even in some of the later Roman manuscripts. One needs only to look at the letters to recog-

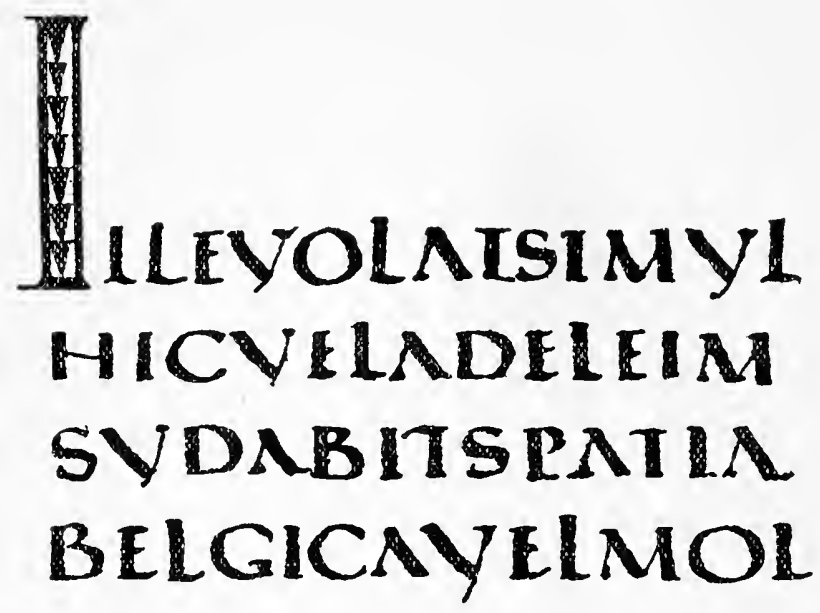

Fra. 24.

Roman capitals from a manuscript of Vergil's Georgics. The letters here reproduced show the first parts of four successive lines and are to be deciphered as follows:

Ille rolat simul ...

IIic vel ad Elei $\mathrm{m}$...

Sudabit spatia ...

Belgica vel mol ...

(Copied from Arndt's Tafeln.)

nize at once that in the modern world many of these same Roman capitals are still doing service where straight, angular letter's of great legibility are desirable and possible.

The capitals represent what we may call the maxi- 
mum of legibility. It would be difficult to improve upon these forms if mere legibility were the only consideration in the formation of letters. But there are other considerations than mere legibility. The capitals are very clumsy letters to write. One could not write very rapidly when he had to make those sharp angles and separate letters.

The demand for a more rapid form of writing must have made itself felt very early. Indeed, we have evi-

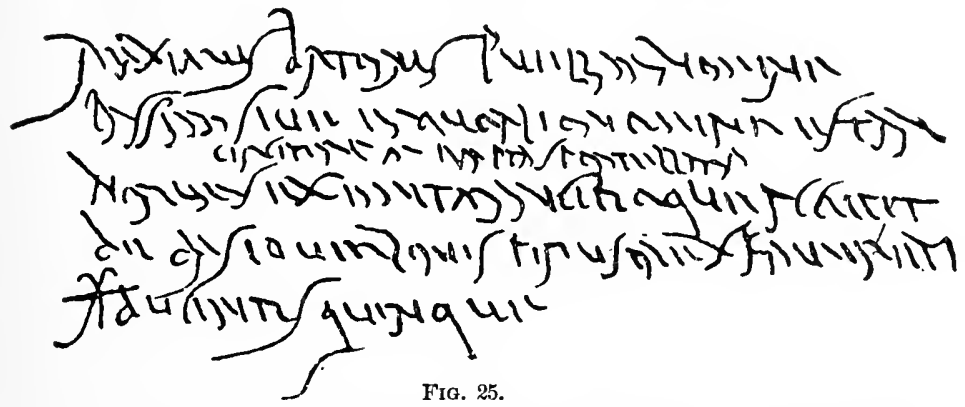

Early Roinan cursive from wax tablet written in the year 139 A. D. It relates to the purchase of a slave girl. It is to be deciphered as follows:

Maximus Batonis puellam nomine

Passiam sive ea quo alio nomine cst, an circiter plus minus empta sportellaria norum sex emit mancipioque accepit de Dasio Verzonis Pirusta ex Kaviereti \# ducentis quinque.

(Copied from Arndt's Tafeln.)

dence from a few business records belonging to the beginning of the Christian era that even the early Romans had a rapid running hand which was used for ordinary business records. In Fig. 25 you see a speci- 


\section{GENETIC PSYCHOLOGY FOR TEACHERS}

men of this early Roman eursive, as it is ealled. This cursive differs from the eapitals in a number of eharaeteristies. The letters tend to run into eaeh other. Indeed, in some eases in even the earliest eursive, there are eonneeting lines or ligatures between the letters. These ligatures are regular and pronouneed characteristies of all the later forms of eursive. Their less frequent appearance in the early forms is due to the fact that this writing was done for the most part on very unpliable wax tablets, and was, eonsequently, by no means as free and easy as was the later writing which was done after better materials had been diseovered in papyrus and vellum on which one could write with pen and ink. Finally, it must be noted that this early eursive writing is by no means as regular or legible as is the writing made up of eapitals. Something of the regularity of form and of the elear-eut legibility of letters is always saerificed when rapidity of exeeution beeomes the ehief eonsideration. Note also the tendeney toward baek-hand slope in the lines, a feature evidently due to the effort to gain greater speed.

The eontrast between eapitals and eursive is the ever-reeurring eontrast between forms of legible writing and forms of rapid writing. As one eomes down through the later periods of the history of writing, he finds a sueeession of forms devised like the capitals for legibility and beauty, and on the other hand he finds other forms devised for rapid and easy writing. The tendeney of the beautiful and very legible forms is to beeome more and more regular and diffienlt to make, and the tendeney of the rapid forms is to beeome more 
and more difficult to read. Human nature does not seem to have changed much in these respects.

After the Roman capitals and the early cursive, there grew up a kind of compromise form which was more rapid and less angular than the capitals, and hence easier to write. It was used, however, only by the book-making scribes, for it was still too difficult for ordinary use. This form is reproduced in Fig. 26 and

\section{quoscumcos

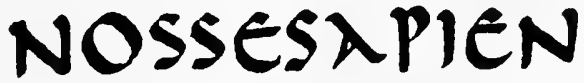 \\ IISESITUMUE

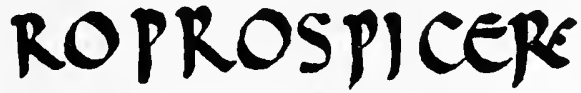

Fig. 26.

Uncials from a manuscript of Cicero's De Republica. The manuscript was probably written in the third century. The lines are to be deciphered as follows:

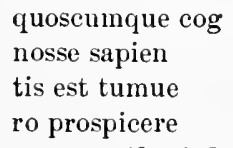

(Copied from Arndt's Tafeln.)

is the so-called uncial form. A typical letter in this form is the letter $e$, which is no longer angular as it was in the capitals, but is much more like our lower-case letter. The derivation of this round $e$ from the square capital is sufficiently direct to be obvious. The motive for inventing this new form is also obvious. The 
round letter is mueh more eeonomical in the number of movements whieh it requires. In the square eapital, the upper and lower horizontal strokes and the one vertieal stroke, all had to be made separately. In the round letter, one uninterrupted eurved movement was substituted for the three separate movements just mentioned. The single curved movement is therefore to be looked upon as a concession to the demands of movement. But the eoneession to movement would never have been possible without a ehange from the earlier writing materials. This ehange has been deseribed by an eminent authority in the following sentenee: "T'o the substitution of a soft surfaee for a hard one, of the pen for the graving tool, we undoubtedly owe the rounded forms of the uncial letters." 1

One may say that the process which shows itself in the development of this $e$ is the typieal proeess of compromise whieh has been going on since the Roman period even down to our own time. There is a eonstant and growing eoncession to the demand for easier movement on the one side, and a elcar effort on the other side to preserve the legibility and beauty of the letter. The great variety of forms invented since that early date are nothing more nor less than the experiments of the race in legibility and beauty, and ease and fluency of writing.

During these experiments almost every coneeivable form has been tried. The widest extremes have been reaehed and fortunately abandoned. The cursive grew so illegible in the thirteenth century, we are told, that

${ }^{1}$ E. M. Thompson, Ency. Brit., 9th ed., vol. xviii, p. 145. 
Frederick II was obliged to prohibit its use. The tendencies toward elaboration among the careful and artistic writers went to such extremes that we are told of months spent on a single letter.

With the invention of printing there entered a factor which tended to put a stop to experimenting with forms. The makers of types began to select from among the various scripts used by the scribes of the time, and the alphabet began to settle into its final form. The German printers, for example, selected the forms we know as the Gothic letters. The world has decided that the German printers made a mistake, and most of the rest of us, and even some of the better German printers of to-day, are using the much simpler and more legible forms of the old Roman capitals and later uncials.

The invention of printing also fixed out English script. We borrowed the style of letter that had been made permanent by an Italian printer. Before we turn to that matter, however, let us glance at one or two forms of medieval script which will show us what we escaped. Fig. 27 reproduces one of the most elaborate and fantastic of the early scripts. It is without the virtues of beauty or legibility, and it was too elaborate to survive in a busy world. On the other hand, the specimen of Anglo-Saxon writing shown in Fig. 28 certainly is beautiful and legible; its cardinal, and fatal fault is its elaborate and unwieldy form.

We are indeed fortunate in the form of script which was finally adopted in England. We are fortunate as compared, for example, with the Germans, who are even to this day struggling with an elaborate and angu- 
lar form of writing. And it is to Italy, as I said a moment ago, that we owe our script. In the days of Queen Elizabeth the educated Englishman went to Italy

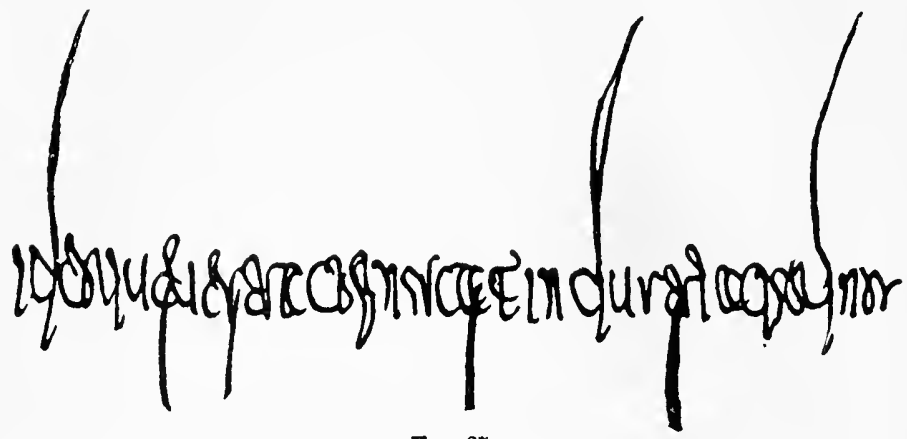

Fig. $2 \%$.

A specimen of Merovingian cursive from the year 688 A. D. The part here reproduced is the end of the first line of the manuscript. The four lines which appear below the letters and extend into the writing, are the upper loops of some of the letters of the line just below the one here reproduced. The letters are to be deciphered as follows:

Ideoque vestra cognuseat industria quod nos

(Copied from Arndt's Tafeln.)

to gain the polish which comes from contact with an older civilization-much as we go to Europe-and from Italy he brought back a simple, beautiful, running script. This script was borrowed from the form of printed letters which we call italics. The very name italies shows you that the type was made in Italy. The story goes that onc of the famous printers by the name of Manutius Aldus, who did his work early in the sixteenth century, copicd the handwriting of the great scholar Pctrarch, and that Pope Julius, in recognition 
of the beauty of his new type, granted Aldus exclusive right to use the same. This type of Aldus became our italics, and undoubtedly was one of the most influential factors in determining our modern form of script.

The general form of our letters was thus fixed after long periods of development. The race had to experiment a great deal in order to settle certain questions. But it has settled some matters definitely for us who inherit the benefits of all this experimentation. No one can tell us in these days that the chief function of handwriting is to be as legible as possible. We have a model of regularity and legibility in our printed capi-

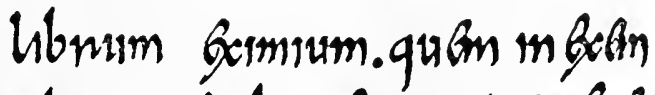 phum reouhriganinuro ophere.

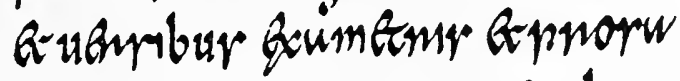 conpopure. Scmprto Reuliw}

Fig. 28.

Anglo-Saxon forms from the eighth century. This is a manuscript of Beda's History. The lines are to be deciphered as follows:

librum eximium, quem in exem
plum Sedulii geminato opere,
et versibus exametris et prosa
conposuit. Scripsit et alia

(Copied from Arndt's Tafeln.)

tals, and we have preserved these forms in our printing just because they were very regular and very legible; but our fathers some hundreds of years ago gave up the employment of these capitals for the ordinary uses of 
every-day life and compromised with the legitimate demands for fluency and case of execution.

It would seem as though the forms of many centuries might be appealed to in settling certain otlier questions. For example, all cursives have a certain running slope which grows too great when onc writes very rapidly and carelessly, and which tends to disappear when one tries to write the most legible hand that can possibly be written. Perhaps it was an accident that Petrarch wrote with something of a slant. Pcrhaps it is an accident that most fluent writing of the type which imitates italics has a slant. Perhaps it is not an accident. Certainly history offers us a plain lesson in the fact that rapid writing tends as a rule to slant; more elaborate writing, especially when it becomes drawing, does not.

For my own part, I am not sure that the clear testimony of history that human nature tends to become careless when too fast writing is attemptcd, is not sufficient justification for the demand that children spend some time at first in drawing letters. I am not surc that the final slant of letters should not be allowed to appear after the drawing stage has passed. I am not sure, in short, that the compromise between the two tendencies toward legibility and rapidity does not have to be worked out in each individual.

I wish I might induce each one of you before I leave this brief historical sketch to interest yourselves in some study of these matters. There is a very good article under the title Paleography in the Encyclopedia Britannica which all of you could read, and any good library will have other material on the subject which 
will show you how mueh we depend for our present forms of writing on the labor of past generations. It is history of this type that will make us a little slower than wc sometimes are in introducing sweeping innovations into our schools.

Of eourse, history can not solve all our doubts and difficulties. We must progress and improve, and progress means a better fitting of historieal inheritanees to present needs. With an alphabet evolved through long centuries on the one hand, and with the modern child on the other hand, the teacher's task is elear. What the study of history does not settle definitcly, the study of present-day human nature will tend to make more plain. If wc are in doubt as to whether ehildren should draw or write at first, let us study the modern faets as revealed in modern men and children, and let us try to answer our question from sueh studies.

Our studies of adult habits of writing and of historical developments of lettcrs have led us to a gencral point of view whieh we shall adopt in the rest of our study. An casy, flucnt, well-coordinated movement, produeing lettcrs of a fair degree of legibility, is the cnd at which we aim. The movement must be highly developed enough in the end to be automatic, so that attention may bc free to follow the thoughts expressed. And in looking toward this end, we must realize that the child has to pass through stages of immaturity at which the movement is not fluent, and attention is not free, at which the forms of letters must be studied, and at which the mind is absorbed in the process of writing rather than in comprehending meanings.

Certainly one ean easily approaeh the practieal prob- 
lem of cultivating an easy, fluent movement in the child, from the negative side, by watching a child trying to write. If there is anything that can be definitely said of the child's efforts, it is that they are not fluent and easy. The child's movements are jerky and discontinuous. They are cramped, and excessive in the amount of energy which they require. They are uncertain, and seem to surprise the child as much as they do the teacher. In short, there is obvious lack of control and organization. We have alrcady suggested that the adult can acquaint himself with the acconlpanying mental attitude which attends the child's efforts to write, by trying to perform the same task with his own untrained muscles. Under such conditions the adult's movements will also show lack of control and lack of organization.

All these excessive and unorganized movements of the child are the raw material, if we may use that term, out of which a flucnt, easy movement must be developed. The child's movements and those of the adult when he tries to use unpractised muscles, are called diffuse movements. You will have no difficulty with that word, I am sure, for nothing is more obvious than that the untrained movements are too much spread out. The right muscle docs not contract at the right time, and the whole irregular mass of activities lacks organization in just the way indicated by the word diffuse. And diffusion of movements can be understood when we recall our earlier discussion of the disturbing effects of sudden loud sounds on the regularity and control of movement. The real seat of diffusion is not in the muscles, but in the nervous system. When 
the muscles move diffusely this is sure evidence that the impulse in the nervous system has been spread out or diffused, rather than carried along definite fixed channels. And finally, this diftusion of impulses in the child's brain not being due to any sudden strength of the impulse, as it was in the cases of disturbance through sudden sounds, is explained by the fact that in the child the brain mass is itself unorganized and diffuse. The regular lines of connection necessary for coordination have not yet been laid down. An impulse is free to wander about and shoot out at this point or at the other, in a very irregular and uncoordinated fashion. The child's brain, therefore, needs organization to overcome this natural diffuse state; and the irregular movements with which he starts are, as we have said, the raw materials for development to work over.

I want to digress from our main discussion for a moment to call your attention to the fact that if it were not for this diffuse condition of the child's nervous system, there would be no hope of cultivating any individual habits of action. Suppose that all the possible lines of connection through the brain were inherited by the new-born infant ready for action. Then every form of movement would be fully provided for, and the infant would simply go ahead in a prescribed way without any possibilities of bringing forth in his own experience original forms of action. This is very nearly a true description of the condition of such an animal as the chick. The young chick just out of the shell, has a brain which is inherited in an almost completely organized condition. The young chick can, therefore, do whatever it is going to do in life fairly 
well from the very first; but it has no large possibilities of developing individual modes of action. Diffusion, as opposed to the chick's condition, means possibilities of organization. Absence of diffusion means completed development, and eompleted development always has a negative side. Where you have completed development you can not have possibilities of new and original individual habits.

With this word of digression to remind you that the child's diffuse nervous eondition and diffuse movements are the necessary raw material for the development of a fluent individual form of writing movement, we proceed to discuss one or two of the details of this matter of diffusion.

One of the most noticeable faets about the child's diffuse movements is the fact that these movements are excessive, espeeially the movements of the finer museles. Somewhere or other the false notion lias erept into our pedagogy that the child's fine muscles do not develop until later than the large muscles. How can one believe such a false statement when he sees a young infant elutching with its little fingers and exhibiting in this grip one of its strongest movements? How can one believe this dogma when he sees the boys and girls in the first grade doing all the work that they do in writing with the fine finger muscles-literally overdoing this work in a very notieeable degree? The fact is, the finer muscles are in full operation very early in life. Indeed, they are the muscles which in diffuse movements are most apt to be called into action. It requires a less powerful excitation from the nervous centers to set the fine muscles into aetion. They contract 
at the slightest stimulation. These are the museles which always grow tense first in later life when the brain beeomes overexeited. In emotional exeitement, for cxample, it is the fine museles of the face and hand that are first affeeted. One's fingers are folded into his fist long before he strikes the angry blow; one's jaw is set long before he speaks the angry word. In short, diffusion always exaggcrates first of all the movements of the fine muscles.

It is elear, however, from our earlier study of adult handwriting that the fingers alone ean not do the work. The fingers become eramped-they must have an opportunity to straighten out. They must be earried forward by the arm in order to get aeross the page. These additional arm movements are made by the ehild, not as well-eoordinated additions to the finger movements, but rather as separate and clumsy interruptions of the finger movement. The ehild writes with the fingers until they are so eramped that he can write no more. Then he stops the finger movement entirely and with a sigh he carries his hand aeross the page and settles down after this interruption to more writing with the fingers. While the finger writing goes on, the hand and arm are all the time, through the diffusion of the stimulation, kept tense and ready to move. Indeed, while we are notieing the fact that the fingers are the parts that are most affected by diffusion, do not let us fail to reeognize the faet that a grcat many other museles are sharing in the diffusion. Not only the writing arm is diffusely eontraeted, but the other arm also is having its part in the agony of effort. Have you not seen the left hand under the desk folded in a grip almost strong 
enough to drive the nails into the flesh? Have you not seen the left elbow drawn up against the side as if it would fain get over and help the right hand? This is all diffusion. So are also the facial contortions and the bodily movements and the movements of the legs. The bending of the head down to the paper, of which we complain so much, and whieh some people have falsely told us can be corrected by using this or that patent pen, or desk, or paper, is a natural consequence of the diffusion of the motor impulse throughout the whole body, and is also the natural bodily expression of intense visual attention.

In movement, as in every other sphere, nature attacks her problems of development by producing more than she needs and then picking out the best. Nature produces more flower-seeds in a single year than could grow on hundreds of times the amount of soil available on this earth, and then she lets the seerls struggle against each other until the best and strongest survive. And so it is with movement. Nature starts out with a diffuse brain as if she would say to the individual, "I will not plaee any restrictions upon you, but will let you have at first all the possible movements to select from." She stirs up the brain in all directions, and the diffuse movements begin to appear in abundance. There are movements of the head and arms and feet and trunk. Not all are necessary to the final form of action, and most will drop away as development goes on. But in the whole mass of movement the right ones must be there, and development means the selection of the right movements out of the total mass of diffuse movements. Only one limitation appears in all this 
provision of many movements. That is the linitation we have noted. No mechanism could be devised which would not, in the general stimulation of the muscles, affect the small muscles more than the large ones.

This limitation in nature's provision for free movement, is the first point at which the teacher's rational mode of developing the child must come in to supplement nature's provisions. The teacher should see to it that if diffusion tends to emphasize the small muscles, teaching should emphasize in duc measure the large muscles. Thus, some teachers begin the tcaching of writing by free use of the blackboard, becausc on the blackboard the larger movements have better opportunity to show themselves. Even if you try this, you will notice that through diffusion the fingers grasp the crayon too intenscly, but yet the larger arm movement will be called into play, and that is well. Blackboard writing for a whole class, and during many years of school training, has many obvious objections, and so it is well to devise some other method of supplementing nature and of calling the large muscles into play. Large arm exercises are the most available devices for attaining this end.

I am well aware that these large arm exerciscs are by no means novclties in our teaching of writing. What we nced, however, is to come to recognize them, not as mere incidental exercises to be taken now and then, but as the staple forms of early writing lessons. I am fully acquainted with the desire of children and even of parents, that the ability to produce actual writing should be cultivated as early as possible. I am also aware of the fact that teachers do not commonly see any imme- 
diate results from these large frec exerciscs. Indeed, time and time agrain, I have seen neat, regular letters produced in copy-books by classes who never had any of these large arm circles or ovals. But our discussion up to this point has failed of its whole aim if you are not convinced that neat letters in a copy-book are not the ends of writing instruction. You are not succeeding in your duties as teachers if you are led by the desires of parents and children rather than by the larger considerations of final development. Look at the children who learn to write early, and who learn under a teacher who neglcets the frce exerciscs. I care not what their copy-books contain, look at their hands and arms. See them laboriously and in a cramped position carving out forms as the allcients uscd to before the beginning of the Christian era. Let us put an end to all this! Let us give up the notion of writing too soon, and let us train the arm with its larger coordinations, systematically and conseientiously, until its movements shall become throngh training coordinate in number and importance with the finger movements of which nature has furnished such a superabundance.

If we could have such frequent exercises in arm movements we could well afford to leave the ordinary writing exercises cntirely out of our school programs for at least two years.

I do not wish to be understood as subscribing to the doctrine that is being offered to teachers by certain prominent educators, that writing should be left to grow up “incidentally" in connection with manual training and shop work. Writing seems to me to be too important a part of school training, too closely connected 
with reading, and too complex a form of activity to bc neglectcd. Activities of such a complex type may grow up incidentally if conditions are not too loosc, but then they will grow up in what we have callcd a non-rational way. Better far that we should devote the energy of the school to a rational cultivation of the right kind of movement. Let us have writing exercises, but let these cxercises be planned to supplement nature, not to hurry nature, nor yct to leave the whole task to nature.

Another important stcp in supplementing nature, besides that which $I$ have mentioned of having many frce exercises of the large muscles bcforc the school writing is taken up, is to recognize and act upon the principle that the writing teacher is not concerncd mcrely with the hand that docs the writing, but is rcsponsible for a training of the body as wcll. During the effort to write, the child is wholly unconscious of the diffuse movencnts which kecp the other arm and the face and the legs in motion. It is not cnough to tcll him to sit up straight from time to time, we must train him to sit up straight. The only way to get good position in writing is for the teacher to make just as much of a point of position as he makes of the work done on papcr. Remember that it is the habit of the child that you are training, not the end of the pen. You can get good copy to show your supcrintendent even if you neglect position, but you can never train good writers.

The third principle I wish to lay down is one that involves some dangerous possibilities of misapplication. And yet in spitc of these possibilities of misuse, I wish to cmphasize this third principle as perhaps more im- 
portant than any other. Bricfly put it is this, evcry child should be allowed to sit and hold his pen and paper, and move his hand in the way best suited to develop his own individual mode of action. Every child is an individual problem to the teacher.

I said that this statement involves a good many possible dangers. In the hands of a careless or uninterested teacher, a class that is allowed individual liberty simply goes wrong at almost every point. Such a class does not have, however, what wc should call individual libcrty, it has rather licensc. The teacher who is careless and lets the children do as they please is by no means following the injunction to let the children do what is individually best for them.

I once saw a class in a school where the teachers werc trying to devclop the principle of individual training, and in that class about half the children were lolding the pen between the first and middle fingers. Now, I shall by no means make the asscrtion that this position of the pen is bad. On the contrary, I have found that it is, in practical life, a very common position of the pen - certainly more common than the orthodox position which is described as pointing over the right ear. But, good or bad, the position of the pen in that class was wholly without justification. We found on some inquiry that the position in question had recently been imported into the class by a boy in one corner of the room, and that it had spread as a sort of fad. The children were many of them having difficulty with it, but it was the fashion, and hence was being acceptcd. I am not sure that children have not a right to introduce fads into the writing class. Certainly there has 
been much introducing of fads among their elders. But what I object to in this particular case is the interpretation which the teacher gave the principle of individual training. To leave the child to pick up whatever strikes his fancy is not individual training, it is educational anarchy. What that teacher needed to learn was the fact which I am trying to make clear in this statement to you. Individual training means a careful study of individual needs, and a suggestive, helpful guidance on the part of the teacher.

Helpful guidance should try to work out such a problem as that on which the children just mentioned were working, namely, the problem of holding the pen correctly. I often ask teachers whether they have ever worked out that problem of holding the pen. I will venture the generalization on the basis of a good deal of past experience in asking this question that if we could get a free expression of opinion on this topic, we should find that the directions given in the books are very seldom really accepted by teachers themselves, and even less frequently accepted by practical people. As a matter of adult writing, each of us holds his pen as he can best use it. Each of us has determined that position by a good deal of practise and non-rational adjustment. This lack of uniformity in actual practise is the outcome of a system of education which went forward according to an assumed rule of uniformity in training. How much time do you suppose you and I lost because we had to hold our pens in a position wholly unadapted to our needs? Are we any better off because there was a theoretical rule about pens preached to us crery day? If not, what would have helped us? 
Would it not have been better for the teacher to have given up preaching a purcly theoretical formula about how the pen should be held, and to have helped us in developing our own way as rapidly and as well as possible? It is not an innovation in real life that $I$ am asking you to consider. For in real life, the boy or girl does, sooner or later, develop his own position in spite of his teacher. What I am asking you to consider is the advisability of abandoning a false theory of impossible uniformity and of adopting the more rational method of helping the boy or girl in what he or she will do, and what he ought to do in any case. If this is an innovation in pedagogical theory and practise, then so much the worse for the theory and practisc.

What I have said about the holding of the pen I should like to repeat about many of the other phases of writing. I should like to venture even on that most delicate of all topics, the topic of the form and slope of letters, far enough to say that I believe the day is coming when the pedagogical world will be at peace on this question, because it will be seen that writing is not a question of forms and slopes, but of individual habits. After a copy has been set long cnough to make the young child recognize the fact that the race lias a better alphabet than he could invent offhand, I believe that the copy has lost its chief significance. Let the child learn the essential features of this copy by drawing the letters ever so carefully at first, if that seems best, but do not be guilty of confounding writing with drawing. Those teachers who keep the boys and girls at the task of making beautiful copy when they ought to be writing, will have left us when we grow 
wise enough to let each child have his own slope, and it will be better for the schools.

One more suggestion and I am through with the part of our discussion which deals with movement. Every teacher should try to hasten the cooperation of arm movements and finger and hand movements by insisting on rapid writing as soon as the drawing period of the child's training is passed. This again requires a pedagogical insight that shall look beyond the dreadful scrawls which will be produced at first. It requires insight that sees that the true teaching of writing consists in securing beauty and fuency, not merely beauty of form. If beautiful copy is what you insist on laving at first and always, then do not accept this suggestion. But if you can see that the child must somehow work out complete coordination of his movements, and if you can persuade yourself that there must be a period of faitliful devotion to the development of this coordination under the guidance and helpful criticism of a wise teacher, then make it impossible for hand and arm to work apart, by demanding that the total speed be such as to make separate action less convenient than cooperation. If you wish to accept this suggestion in a conservative way, introduce in the very first years, an exercise of a few minutes in rapid writing at the end of a regular copying period. But in some form or other consider the advisability of cultivating fluency of these movements in school.

And now there is one more topic on which $I$ have to touch very briefly. It is the topic of the child's attention during writing. In what direction is the child's attention turned? There can be no question 
about where it is not turned during the early years. It is not turned to the meaning of what he writes. I think another negative statement can be made on the basis of our earlier discussions with equal certainty. The child's attention is not turned to his movements. When we turn from these negative statements to show where the child's attention is turned, positive statement must be made in a somewhat more tentative way, for the child's attention seems to be divided between the copy and his own written letters. Probably his own letters are the factors which most naturally attract his attention. Every teacher has been drilled into the recognition of this division of the child's attention between copy and the child's own productions, by the effort which has to be expended in conforming to what is supposed to be the all-important and necessary duty of bringing the child back to the copy.

Let us consider the question of the advisability of concentrating so much attention on the copy. In the first place, the copy is unquestionably neccssary at first. It is valuable in that it conveys to the child the expcrience of the race in regard to the advantagcous form of any given letter. The copy is the social inheritance, and we say in effect to the child when we give him the copy, "imitate that as you imitate other social practises." The child strives to imitate. Hc comes very soon to get the fundamental lines well in mind. But now the difliculty is that he can not get regularity and fluency enough into his movement to reproduce these forms in a practical way. His muscles do not respond to his mental picture, and he gets poor products. We say to him again, this time in so many words, "look 
at your copy." He looks at his copy, and, without realizing fully the defect in his own work, and ccrtainly without having the muscular control to do perfect work, he tries again to imitate.

Would it not be better to stop this mere reference to the copy in the hope of attaining non-rational imitation, and to substitute for the merely imitative attitude, a critical attitude on the part of the child toward his own work? Do you suppose a child would fail to recognize the fact, if you told him, that his own $l$ was too flat, or his $o$ too much opened at the top, quite as easily as he could see it by looking at his copy? To be sure, his copy would show him these things if he would examine it, but he does not ordinarily examine copy under our present method of instruction. It takes more training than he has to examine copy with a view to making a critical comparison with his own work. The copy shows certain forms to his eyes, but it does not discuss these matters with him as a living, intelligent teacher might. Thus, how easy it would be to get a boy to compare his own $u$ with his own $n$, and he would learn quite as much in this way as by looking at copy. Show a boy the interesting things about his own writing, and you may make his improvement of his writing more interesting and intelligent.

Indeed, the strong tendency which shows itself in every individual's development is to accept his own forms sooncr or later in spite of the copy. We ultimately grow tired of trying to recall the impossible, or at least impracticable regularity of copy, and we settle down to making forms which we consider adequate. If our teachers had only thought of this and had only 
helped us to cultivate proper ideals within our reasonable grasp, how much better writers we might be to-day! And now when we have come to occupy the positions of teachers, let us give up so much referring of our pupils to a dumb copy, and let us try to improve the boy's own style by individual criticisms.

During the first two years of actual writing, after the free-arm exercises, the copy may be retained as the standard of appeal. After the first year of actual writing, the copy need not, and should not, be made the chief guide. This first year is what I have referred to before as the drawing period of training in the forms of letters. After that first year, the form of the letters ought to be perfectly familiar. Then appeal to the child's own sense of symmetry and beauty, and concentrate training on the task of developing fluency. Allow the child some reasonable freedom in the construction of his letters, but criticize his writing with him. Compare his iregular letters with his own regular letters. Show him how to try again on the basis of his own past efforts. In short, substitute a living, rational teacher and a self-criticizing pupil for lifeless copy. The only value of copy after the form is mastered, consists in its repeated, but too often unheeded, exhortation to regularity and symmetry. After the fifth year there ought not to be any need of criticism. If there is, do not be afraid to use it, but certainly do not use it in the old and non-rational way of presenting mere copy.

The final problem of writing instruction carries us over into our next topic which deals with reading. When written characters begin to have meaning, the art of reading has generally been developed to a high de- 
gree. There is one condition necessary to fulfil in the development of the movement, before the advantages of the art of reading can be fully applied to onc's own writing. That condition we have already discussed in our treatment of the question of the automatic character of writing. Reading can never be applied to writing until the attention becomes frce in some degree to devote itself to meaning rather than to form. Just in the degree in which the child comes to be free from attention to copy and to the form of his own letters, just in that degrce can he think of meanings. The art of sceing meanings in words is, however, a complex mental process, not connected merely with a mastery of the writing movements. We shall, therefore, treat the whole question of seeing meanings in the written words, more appropriately in our next discussion. 


\section{CHAPTER VIII}

\section{THE PROCESS OF READING}

The methods of teaching reading have been very radically modified within the memory of our generation. The spelling-book with its long lists of unconnected words as the necessary introduction to reading, is no longer to be found in our schools. The method of deciphering new words letter by letter is no longer allowed. The monotonous formulas with which the first readers used to begin, are gone, with very little prospect of ever being heard from again. Instead, we have the modern nature-study reader with its phonetic alphabet. We have the reedited literary masterpiece from which even the primary grade pupil is supposed to derive high and worthy thoughts while he is gently led, without all the tumult of former days, into the intricacies of our unphonetic English orthography.

It is as if teachers had suddenly cast off the old notion that children can not grasp meanings in what they read, and had admitted the youngest child into the largest possible use of reading as a means of getting information. Where the old schoolmaster was satisfied to drill his pupils in the forms of reading, was satisfied to take almost any sort of reading material if he could only get the right pauses and the proper rising 
and falling inflections, we pass lightly over the formal considerations and seek to emphasize the import of what is read. We are everywhere seeking the shortest possible road to meanings. If a word can be recognized as a single whole without breaking it up into its letters, so mueh the better, we say, for it is the word as a whole that has meaning, not the letters that enter into the word. If a new word can be introduced in such a conneetion that its meaning shall be apparent without a formal definition, so much the better, we say, for it is the meaning in a practieal form, not in a stilted definition, that we are aiming to eultivate. And so on in every detail of our modern reading, it is the meaning that we are striving to bring out.

All this is in the fullest accord with the spirit of our modern lives. 'There was once a time when reading was a kind of aceomplishment. That was in the days when reading of Latin was quite as necessary a part of a gentleman's education as the reading of English. That was in the days when men did not read the newspaper every morning and did not have bulky eorrespondence to look over in their business. In those days a book or two a year, or even less, constituted the total reading of a family. The Bible, an almanae or two, Pilgrim's Progress, and a few other religious and medical works, made up the family library. But within a half century how all this has changed! One almost hesitates to eount up the amount of reading done by even the ordinary man to-day. The eommon workman reads in these days. Of course he cares little for the short pauses at commas, and the long pauses at periods, and the other formal considerations. He wants 
the meaning of what he reads. And when his boy or girl goes to school, lie wants that boy or girl to learn to read, not to learn to declaim. He sees, and we teachers see, that reading is not an end in itself, but rather a means to something higher.

So eager are we in the pursuit of meanings in our teaching of reading that we sometimes fail to realize that there are any mechanical and formal requirements that must be fulfilled before the child can attend to meanings. It is all the easier for us to overlook the earlier mechanical steps that lead up to the recognition of meaning, because in our developed adult lives reading has become, on its mechanical side, a purely automatic process. We do not realize that there is any process lying between our looking at a printed or written word and our recognition of the signifieance of that word. We do not see the process of development through which the individual passes in any such way as we see it in the ease of writing, and so we not only do not realize the complexity of the process, but we do not realize that it is there at all.

Our first aim in this study of reading must therefore be to bring to consciousness what does not naturally present itself to adult consciousness-namely, the nature of the proeess which precedes and conditions our recognition of meanings.

In undertaking a complete study of the reading proeess, attention naturally turns, first of all, to the eyes which receive the impressions from the printed or written page. It has been possible, by means of photographs and by means of recording apparatus attached 
to the eyes of adults, to discover with a good deal of exaetness just what the eyes do during reading. ${ }^{1}$ They do not travel continuously along the line whieh is being read, but they move along in three or four steps from the beginning to the end of the line. That is, they move through distances which measure about an inch along the printed line, then they pause for a moment, and after the pause, move through another inch. After erossing the page in this series of steps, they eome back in one long continuous sweeping morement to the beginning of the next line and then proceed again by steps across the page.

During each period of movement, the eyes see nothing. It is only during the pauses between morements that the eyes see. This has been demonstrated in a variety of ways by some of the ingenious seientific investigators who have studied the problem of how the eyes behave during reading. There is one very simple way of demonstrating these facts, to which Professor Dodge has called attention. ${ }^{2}$ 'Take a looking-glass and try to see your own eyes move. They will never be seen moving. During actual movement, the eyes do not see anything. It is only when they stand still and fixate some point that eonscious recognition is possible. It is evident, then, that the points where the eyes stop in their steps across the page are the points of interest to us in our study of reading. At sueh points the eyes see before and behind, taking in all the surround-

1 Erdmann and Dodge, Psychologische Untersuchungen üher das Lesen, 1898. Hney, Amer. Jour. of Psycholngy, 1900, p. 283.

${ }^{2}$ Psychological Review, vol. vii (1900), p. 456, and in earlier works there referred to. 
ing letters at a single glance and then step on to the next point of fixation.

The number of points of fixation is of interest to us, for this number shows us what is the range of letters or words that can be taken in at a single glance. Make the observation for yourself sometime. Sit down in front of some one who is reading, and notice how the eyes move. Count the number of steps in passing across a line. You will find that the number of steps will differ from line to line and from individual to individual. It would be an interesting study if some one would make a table of the different ways in which different individuals move their eyes across a given line of print. Think, for example, of the difference between an adult and a child in this respect. A few observations that I have made, show that children move the eyes very slowly across the page, taking many more steps than do adults. How many such steps a child takes, one can sometimes see from the way in which the child uses the finger to point to the place. The finger is a kind of landmark to aid the cyes in their fixation, and it helps in keeping the path during the long journey through the jungle of letters where short, uncertain stcps are in danger of going astray.

These facts of movement are of importance when we study the process of recognition of words. It is evident from the very movements that in adult life we do not treat the letters as separate objects of attention. Te look at the letters in groups. This fact has been demonstrated in certain other experiments dealing with the time required to recognize words. It has been 
found ${ }^{1}$ that the time required to recognize short words made up of four or five letters, is no greater than the time required to recognize a single letter standing by itself. The niovement of the eyc corresponds thus directly to the movement of the attention. Both the eye and the attention move across the line in stcps or stages, not in continuous recognition of each successive letter.

We come thus upon a new confirmation of the principle which we laid down in the fifth chapter. You remember that we there called attention to the fact that the impressions made upon the eycs might be the same in the child's life and in the life of the adult, and that the movement made in response to these impressions might be very different. This movement, or fact of expression, stands, furthermore, as we there pointed out, in very much closer relation to the mental development of the individual than does the fact of impression. No better confirmation of all this could bc found than that which we find in the like impressions from the printed page which come to the child and the adult, and the utterly unlike movements of the traincd and untrained eyes as they move across the page. The stage of mental derclopment attained in these two cases is indicated by the kind of movement, not by the kind of impression.

There is another group of movements connected with our adult recognition of words which serve to emphasize the principle so obvious from our study of the eye morcments. This second group of movements con-

1 Prof. J. MeK. Cattell, Philosophische Studien, vol. iii, p. 485. 
sists in certain involuntary tendencies to articulation which always accompany our reading.

You must have noticed, at some time or other, some adult who was moving his lips in inaudible whispers as he read with profound attention from the newspaper or from some written or printed page. If you have never noticed an adult doing this, you are certainly familiar enough with the tendency of children to do it to such an cxtent that the whisper becomes at times even audible. What that adult does with his lips, and what children often do so intensely, we all of us do in some degree with our vocal cords and other organs of articulation. Indeed, not only in rcading, but cven in thinking, we always tend to spcak the word which wc have in mind. So that we may lay it down as a general fact that rccognition of a word, or thought about a word, is always accompanied by a tendency to articulate that word.

It is an interesting story of scientific investigation that lies back of the best demonstration which wc havc of this fact of involuntary whispering when we think of words. Two Danish scientists ${ }^{1}$ became interested in some English investigations of what is known as telepathy. Telepathy is the name for the supposed process of thought transference. There are some pcople who believe that one mind can affect another at a distance, in such a way as to make the other mind think the thoughts of the first, and they call such influence of mind upon mind "telepathic influence." Two English

'Mansen and Lehmann, Ueher unwillkürliches Flüstern, Philosophische Studien, vol. xi, p. 471. 
scientists made some experiments on telepathy. Their investigations consisted in a carefully recorded series of trials which aimed to determine whether one person who was sitting at the end of a long corridor and thinking intently of a certain number, could influence the thoughts of a second person at the other end of the hall, sufficiently to result in the second person's guessing the right number. The person who thought the number was, of course, to think to himself and in no way to communicate with the guesser at the other end of the hall. The English investigators, after a very carefully conducted series of such experiments, found that the guesser had succeeded in getting the right number a good many times, and they concluded that there must have been some sort of transfer of thouglit.

The Danish scientists who became interested in these experiments on tclepathy were doubtful as to the conclusion that thought had been transferred. They said that perhaps it was some form of physical energy that had carricd the communication from one person to the other. At any ratc, they thought of a way of deciding whether or not it was physical energy. All forms of physical energy can be focused. You know, doubtless, how sound can be focused just as well as light. So the Danish investigators repeated the English experiments, with this modification-they put the thinker and the guesser at the foci of two focusing sound mirrors; and they found that the number of right guesses was decidedly incrcased. But where did the sound come from? The thinker had been perfectly sincere in the experiment, and had produced no sound so far as he knew. The rest of the demonstration is what inter- 


\section{$2 \pm 4$ GENETIC PSYCHOLOGY FOR TEACHERS}

ests us in our study. The thinker had been involuntarily whispering the number with every expiration of breath from lis lungs. 'The more intensely he thought of the number, the more firmly his vocal eords and other organs of articulation became set for the name of the number of which he thought. The air breathed out with each expiration was enough to give slight sounds, and these slight whispers when focused, helped the guesser even more than they had helped him before being focused.

Every time we eoneentrate attention on a word, aceordingly, whether it be in reading or in the mere effort to think of the word, we tend to make a movement of articulation. The investigations just reported are not the only ones which prove the truth of this assertion. Some years ago Professor Münsterberg ${ }^{1}$ tried some experiments on the remembering of words. He found that if he prevented the person who was trying to learn certain words from making the appropriate artieulation movements by requiring him to hum a tune, or to say $\mathrm{ah}$, ah, ah, continually, the proeess of remembering was mueh interfered with. This experiment has been repeated by a number of investigators with many modifications, and it always gives the same results; showing that the normal accompaniment of attention to words is a movement of articulation.

These movements of articulation, like the movements of the eyes across the page, correspond, not to the single letters that make up the visual impression,

1 Zeitschrift für Psychologie und Physiologie der Sinnesorgane, vol. i. 
but rather to the words as wholes. Indeed, in their most highly developed form they may undergo a further reduction which we do not understand very fully, by which a single unitary movement may correspond to a whole group of words, rather than to even the single words.

These facts of active adjustment of the individual in his reading, are certainly the results of development. Progressive development turns in the direction of greater and greater eomplexity in both artieulation and the reeognition process. Given the letters in words and the words in sentenees as the material for comprehension, the individual learns to take up these impressions and group them. This grouping of the elementary impressions into larger wholes is one of the most essential faets in the growth of recognition, and, as we have seen, it is always paralleled by some corresponding form of bodily aetivity.

So important for our eonsideration is this fusion of letters into words and of words into sentences that we must dwell upon it witl some detail. We are fortunate in having a seientific record which will throw light on our diseussion of this matter. The scientific record is not direetly related to the common proeess of reading printed or written charaeters-it relates rather to the reading of the telegraphie language. It is somewhat easier to get a reeord of what one does in the proeess of aequiring ability to read telegraphie messages. In the first plaee, telegraphy is learned at a period in life when one ean experiment more easily with the learner. One ean measure results more easily, too, for the letters of the Morse alphabet require an 


\section{GENETIC PSYCHOLOGY FOR TEACHERS}

appreciable time for transmission and reeption, and the time furnishes a good means of measurement. We have very little data on the manner of developing the ordinary habit of reading print or writing. Children are very diffieult to investigate in such matters, and the proeesses of reading are always difficult to measure. It is to be hoped that some day, through a careful study of the developinent of eye movements, we may have a direet record, throwing light on the elaraeter of the fusion of letters into words and words into phrases in ordinary reading. In the meantime, we shall get sueh light as we ean from the investigations of Bryan and Harter ${ }^{1}$ on the development of ability to reeeive and send telegraphie messages.

The eharacter of the investigations is not diffieult to understand. Men who were learning to receive and send telegraphic letters, were tested at the end of eaeh week of praetise as to the number of letters they eould send and reeive per minute, and the results for a period of months were reeorded in the eurves reprodueed in Figs. 29 and 30.

The eurves in Fig. 29 represent the improvement of a single learner in a period of forty weeks. The upper eurve is the sending eurve; the lower is the eurve for receiving. Notice two facts, first, that the learner shows more rapid improvement in sending than in reeeiving. The parallel to this fact in reading is that one must learn the aetive side of reading, espeeially the artieulation side, before he learns to reecive ideas from the printed page. We have seen how the art of 
writing was influenced in its development by the fact that men had a well-developed sound language before they began to write, we must never lose sight of the fact that our teaching of reading always follows the

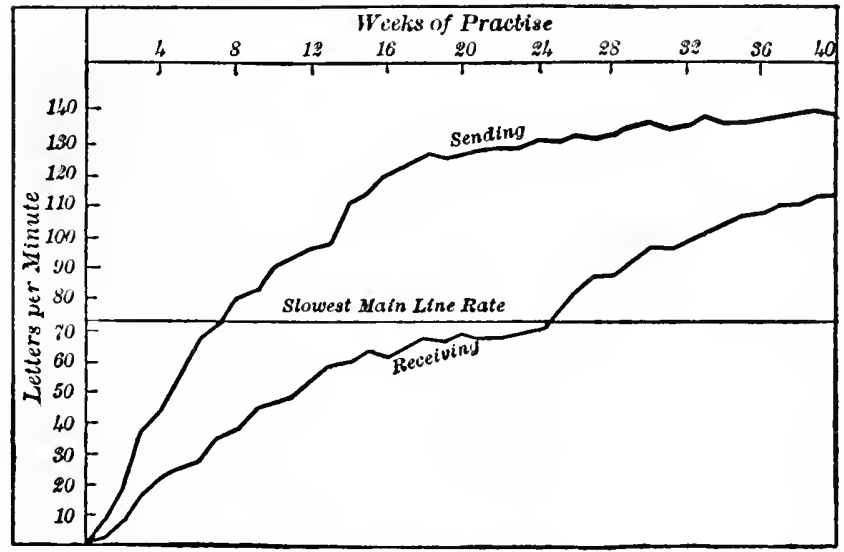

Fia. 29.

Sending and receiving rates of student Will J. Reynolds. Tested weekly by Noble Harter at Western Union telegraph office, Brookville, Ind.

acquirement of ability to speak. The recognition of a word as a whole is one of the important factors, as we have seen, in adult reading. The articulation, which is of words as wholes, is developed as an active fact, before the recognition of written words as wholes is possible. Indeed, one may insist in reading, as in writing, that before the attention is free to get meanings from written words there must be a full development of the activities, that is of the articulations and of eye movements. These must become automatic and must be 
disposed of fully in order to leave attention free for the higher process of fusion of words with thought. 'This lesson of the earlier development of the active processes is the first fact that comes to us from a study of Fig. 29 .

The second fact which you should note in Fig. 29 is that improvement in sending and improvement in receiving, follow different courses. Notice how the sending curve gradually rises to its full height in a regular sweep. There are minor irregularities, to be sure, weeks when the improvement is somewhat slower than usual, but on the average the improvement follows a fairly regular course. With the reeeiving eurve it is very different. At first it shoots up regularly, somewhat like the sending curve, and then suddenly, in this ease at about the fifteenth week, it begins to show no further signs of improvement. Here comes the long level part of the eurve which the authors of the investigation have ealled a plateau. This is one of those discouraging periods which you all recognize from your sehool experienees, when there is no marked improvement, just a standing still as it seems. But do not be diseouraged by these plateaus, for as you see in our curve, there comes ultimately an end of the period of standing still and then there is another sudden rise. This plateau represents in education a necessary period of readjustment and assimilation. It is a period of preparation.

We must interest ourselves further in this dificrence between the sending and the receiving curve. It is not enough to say that the growth of ability to receive passes through a period of delay until certain steps of 
development can be fully prepared. Wc are interested in knowing definitely what these processes of devclopment are. The investigators of the telcgraphic language have given us a good deal of light on this problem by their later investigations rccorded in Fig. 30 .

Here they show in the upper curve the same kind of a receiving curve with its plateau, as that which we have

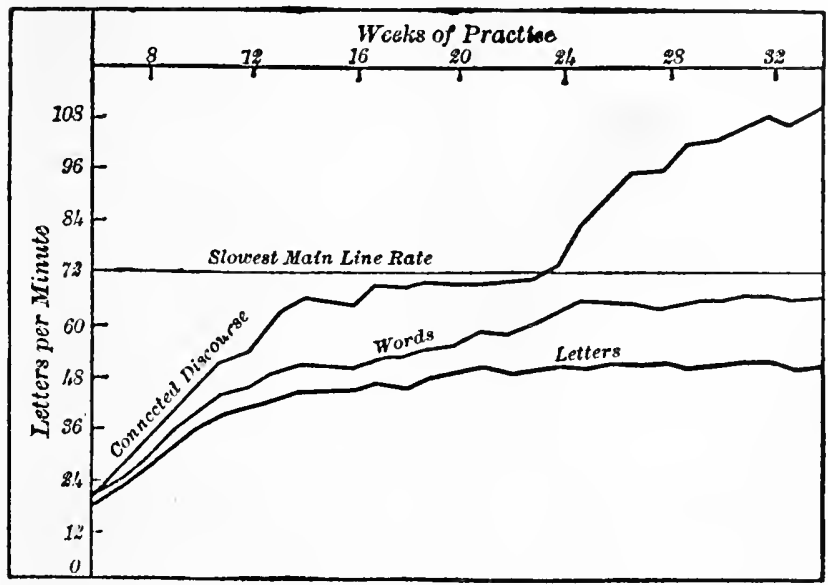

Fia. 30.

Receiring rates of student John Shaw, Brookville, Ind. Tests began with seventh week of practise.

already studied in Fig. 29. This upper curve in this figure shows what could be done under the ordinary conditions where the letters united to form words, the words in turn entering into sentences. The middle curve of Fig. 30 shows the rate of improvement in the reception of words which did not form sentences. This curve shorrs, accordingly, what happens when letters unite to form 
words, but the words are unrelated. Finally, the lowest curve shows the rate of reeeiving isolated letters which did not form words at all. The interesting and signifieant faet about these three curves when thus eompared, is that they explain the meaning of the plateau. The plateau comes at the point in the eurve where the power to receive the words as isolated factors has been fully developed. It rcmains for the lcarner to fuse the words into sentences in order to make more rapid reeption of whole sentenees possiblc. The plateau represents this period during whieh conseiousness is gaining suffieient mastcry of single words to make possible the fusion of words into phrases. Certain lower fusions have to be made, for the end of the platcau eomes only when these lower fusions are taken up into higher fusions. It requires a long period of assimilation to prepare for this larger fusion, but with the ability to make the fusion, the rapid advanee after the platcau begins.

There are othcr examples of a similar type which illustrate this kind of development through a plateau period. Time and timc again it has been notieed by those who arc lcarning some forcign languagc, that there is a most discouraging period when one does not seem to make any progress. You begin to learn your German, for example. You learn new words eaeh day, and think you must soon have enough to be able to understand what is said to you. You find yourself even able to speak short sentenees that you have worked out-but the time of understanding is not yet. You go on and on without seeming to advanee a step, until suddenly you wake up somc morning with a conscionsness that 
you can understand whole sentences. You have passed the plateau.

These plateaus, or periods of preparation for higher fusions, are more numerous than our curve in Fig. 30 indicates. This particular plateau in the figure is, as we have said, the one which represents the growth of power to fuse words into significant sentences. It might be compared directly to a certain period in children's lives as they learn to read. All of you know that period when children read word by word. There is no expression or modulation, just a scparate articulation of each word. If you ask the boys to do exhibition reading at this period in life, they exultantly shout out each word as if it were a triumphant success to get that word out, whatever becomes of the rest of the sentence. The next step in the reading instruction after this conquest of words, is to prepare for just such a step of fusion as that which is represented in our curve of telegraphic languagc, the fusion of words into sentences.

This one kind of fusion is, however, as we said a moment ago, not the only kind of fusion involved in the reading habit. There is the first fusion of all, when the child comes to connect a written letter or word with his spoken language. We do not think of this fusion of sound with written letters very often in our analysis of reading. Generally, children brought up in homes where reading is common, know something about the art before they come to school. They have already taken the first step. Something of the advantage that comes to our school work through these early fusions of written words with sounds can be understood when we 
think of that long period during which the race had to struggle with the problem of passing from pictorial writing to a sound alphabet. Or one ean find present-day illustrations of the same fact by going to some institution for deaf-mutes where this eonneetion between written words and movements of the organs of articulation has to be laboriously worked out. It would be a most enlightening experienee for every teacher in our schools to see the methods of training deaf-mutes.

After the first general recognition of the faet that written letters may represent articulations, there is the process of fusion which eombines letters into single words. This is a complicated problem. It deserves more eareful study than it has ever reeeived. Let us try, if we can, to understand something of the eomplexity of this process. Suppose, to begin with, that the ehild had to be taught to read Chinese. You will reeall the fact mentioned in the last ehapter, that the Chinese have a separate eharacter for each word. The process of fusion in each ease of a Chinese symbol eonsists, therefore, in uniting with a eertain written figure a certain articulation. The articulation is all ready when the readiug of the symbol begins, because of the child's knowledge of oral language. All that is necessary, therefore, is to fuse a known articulation with a written symbol. This requires some attention to the symbol to distinguish it from other symbols, and also requires some effort in bringing about the fusion.

The case that we have assumed is the ease that parallels exaetly what we do in our modern methods of teaching reading when we tench in the first years, words as single wholes. I think that this method of teaching 
has the largest possible justification in the fact that the child's articulations which are factors of these early fusions, correspond to words as wholes rather than to single letters or parts of words. The most natural fusion is always the one for which the child's past experience has partly prepared him.

It would be a relatively simple matter to follow this method of associating word articulations with word symbols, if it were not for the fact that we soon find it necessary to analyze both symbol and articulation into elements. The Chinese language is exceedingly clumsy because it has never made such an analysis. Our writing and reading is capable of the greatest possible range of rccombinations bccause we have elcmentary forms as the material for our writing, and clementary sounds as the basis of our articulation. This usc of elcments in writing our language calls for a new phase of training which is never demanded of the Chinese child. Wc can get at the elements, after our first fusion of articulation wholes with word symbols, only by a process of analysis. Such analysis in our English writing and rcading is made doubly difficult by the fact that the elements of articulation do not correspond in all cases to the elcments of the printed word. We all of us rcalize this fact. Our alphabct and written symbols come with few modifications from the ancient Phenicians. The alphabet represented doubtless with some degrec of accuracy the fundamental elements of both writing and articulation for the ancient language. But when wc adopt this ancient, oriental alphabet, and try to fit it to our northern and modern language with its new sounds, we find difficulties innumerable.

This is, however, 


\section{GENETIC PSYCHOLOGY FOR TEACHERS}

what we have to do. We have to take writtcn and articulated words and analyze them until we come to the elements of each.

This process of analysis was what the old spellingbook and letter method of teaching reading delighted in carrying out. Indeed, the old method began with the elcments and after seeing to it that the child mastered the elements, the old method went about the building up of words in a synthetic way. I think wc do better to follow the more natural ordcr. Let the child synthesize or fuse written symbol and articulation first, and then let him analyze from the matcrial in his own consciousness. The warning we necd in our modern methods is that the analysis must not be omittcd.

It is so casy when we have trained the child to attach the right articulation to a word symbol to believe that we havc given him the same mastery over the word that the adult has. But we have not. The adult attaches the right articulation to a given group of lettcrs because the combination of letters is thoroughly under his control as a combination of elements. It is a mere question of method of procedure whether you shall give this full mastery of the word through a placing of clements together as the old method did, or through an analysis of the wholc into its elements as the ncwer methods should. The final stage in either case will be a mastery of both elements and combination. This is what must be had before development can be complete. The trouble with some of our teaching by words rather than letters, is that we sometimes believe that the mastery of elements can be left to take care of itself. It can not. We must teach cur children how to break up articula- 
tions and written words into their elements. This is a necessary preparatory analysis bcfore later and more complex forms of synthesis can be possible.

Now come back to the child who lcarns the fusion of a word symbol with a given articulation, as the Chinese child docs. What shall be the next step? Again I believe that our modern method is right in that it begins the analysis with an analysis first of the articulation process which is under the child's control, rather than with an analysis of the inherited and wholly artificial written symbols. We ought to begin analysis with some sort of phonetic method. I do not know of any phonetic system that is free from objections. But we have had this idea too short a time to work it out fully. That we are on the right road is clear. Let us keep on. The combined cxpericnce of individual teachers is the only thing that can makc the method perfect. Get the principle, and become a worker yourself in the field of constructive method-making.

The phonetic analysis is the starting-point of analysis, but analysis must not be governed entirely by phonetic considerations, for our problem is ultimately to come to a combination of phonetic elements and alphabetic elements. The perfect analytic method toward which we have to work is one that passes from purely phonetic divisions, and that very rapidly, to observation of the corresponding letter divisions. Good spelling results from an acquired habit of observing the elements of words. Good spelling is very easy if attention is trained in this direction early in life, it is difficult if attention gets a wrong bent. There can be no doubt that we tend in our modern methods to neglect analysis. 
This negleet of analysis is one of the natural and most serious results of our modern desire to get at the higher forms of fusion as soon as possible. We are striving so constantly to grasp wholes in their totality that we fail to see that the wholes are made up of elements. Let us correet this fault. The older methods from their very nature avoided this, whieh is our most radieal fault.

Enough has been said to show how eomplex and involved is the fusion of letters into words, and of words with appropriate artieulations. But these preliminary fusions must take plaee before fully developed reading is possible. After these preliminary fusions, eomes the stage of fusion illustrated in Fig. 30, the fusion of words into phrases and sentenees. Conneeted with this last fusion and, indeed, probably as an essential phase of the proeess, is the eompletion of the fusion already begun in the earlier proeesses, namely the fusion of written or printed words with thoughts or meanings.

The eomplete reeognition of the meaning of a word is one of the final stages of development. The reeognition of the sounds eonneeted with letters, the fusion of these elementary sounds into a single artieulation are all preliminary proeesses. The attention ean not be free to take up meaning easily and fully until these preliminary stages have been passed througl. It was pointed out at the beginning of this ehapter that our modern teaehing of reading is in some danger of overlooking all these neeessary preliminaries to the reeognition of meanings. I hope that statement is clear by this time. The meaning whieh eomes so easily in adult writing and in adult reading, is possible only beeause the preliminary proeesses have become automatie. Let us not for- 
get the similarity between the more obvious organizing processes in writing and the less obvious, but no less necessary, organizing processes in reading.

And now as we attack the problem of the final fusion between meaning and written or printed form, we shall certainly not lose sight of the suggestions that grow out of our past discussions. The processes of fusion which we have discussed up to this time are not mere receptive processes, thcy are all intimately connected with certain forms of activity. When the eye moves in such a way as to indicate that words and phrases are taken in as single wholes, we can not fail to see the relation of the active individual to the process of fusion. And when the words of a scntence fuse with the thought which they express, surely there must be some active processes connected with this higher form of fusion.

I think we shall have no difficulty in recognizing the truth of this statement if we go back to our earlicr discussion of the boy or girl who reads by pronouncing scparate words, bcfore those words are fused into sentences. Compare the active expressions of such an untraincd reader with those of one who knows the thought of the whole sentence, and how different are the two! The fusion of the words into a significant sentence will be expressed by a single rising or falling inflection running through the whole group of words. The sentence thus becomcs a single expression. It has elements, to be sure, but the clcments are not held apart any morc than are the elements of the fully developed movement in writing. They are fused into a single active uttcrance. This appears nowhere more clearly than in sentences that convey some emotional thought. Then, 


\section{GENETIC PSYCHOLOGY FOR TEACHERS}

even the rate of articulation may ehange and help to express the emotional eharaeter of the thought. There may also be added to the emotional artieulation of the words some other bodily expression sueh as a straining of the tension of arm muscles, as in anger. The hearing of some sentenees or eren the silent reading of them, may send the blood surging to the brain in a new and distinet response to the thought of the sentence as a whole. Such reaetions as these are not reaetions to the words, they are reaetions to the thought. They appear at a stage of development in whieh there is being worked out a form of fusion higher than that whieh eomes in the mere fusing of artieulations and single words.

The emotional reaetions whieh we have found entering so naturally into our diseussion, are perhaps the most obvious reactions aceompanying these higher fusions, but they are by no means the only forms. Take some simple sentence and try by an examination of your own mental process to see what enters into your understanding of its meaning. It makes no great differenee for our discussion at this stage whether the words with which we start are read, or heard, or merely thought of. The preliminary fusions of written words with artieulations are different from the preliminary fusions of words that are heard with the same artieulations. But onee let words that are heard, and words that are written, be brought up to the point where they ean take on meanings, and the further proeess will be the same in either ease. The taking on of meaning is a form of fusion which is alike for words written or spoken. And if you would understand this proeess of taking on mean- 
ings you must make, as I have said, a very careful analysis of the process in your mind, for a superfieial analysis may lead you astray.

It has been a favorite formula in much of our scienee to say that the meaning of a word consists in a whole series of images of the object to whieh the word refers, this host of images hovering as it is supposed somewhere in memory. A sentence in like manner has been described as associated with a train of images also hovering in memory. But one is led to ask, why this train of images? Is that the end of recognition of meaningsjust to have a series of pictures in the mind? Certainly not. Pietures when they are called up by words are merely the intermediate stages of a more complete process. Every recognition of meaning ultimately results in some appropriate total reaetion. All our earlier discussions of action and its relation to mental life confirm this conclusion. This conclusion gives us the best and highest view of mental life, for under it we think of mental processes as contributing to our adaptation to our broader environment. In securing adaptation, there is no place for mere passive pictures in the mind. Pictures must lead to aetion, and pietures do lead to action. One can not see a picture of a hammer without feeling his fingers reaching for its handle. One can not look down a steep precipice without thinking either of the leap or of turning away to avoid a fall. Pictures are carriers of meaning. When they come into the mind they bring with them as their ultimate consequenees some kind of reactions.

The ultimate value of words when fused with meanings, appears most clearly in the cases of thoroughly 
familiar words. In these cases the intermediate pictures are not necded. If they were ever present they liave disappeared in the course of development. The familiar word passes at once into a reaction. Let me say to you, for example, "here are twelve dollars go and spend them," and I venture the guess that you did not think of my single words at all. You had only the haziest sort of a picture, if indeed you had any, of how the twelve dollars would look. The first thing you catch in consciousness as a result of my sentence is a feeling of yourself in some store doing what we were talking about your doing. If we had all the necessary apparatus attached to your muscles we should find them responding to the words that went into your ears with actual muscular contractions which faintly, but no less surcly, tend to realize the command to "go and spend it."

Professor James will help us again in our effort to make this idea clear. He writes on page 27 of his Talks to Teachers as follows: "No truth, however abstract, is ever perceived, that will not probably at some time influence our earthly action. You must remember that, when I talk of action here, I mean action in the widest sense. I mean speech, I mean writing, I mean yeses and noes, and tendencies 'from' things and tendencies 'toward' things, and emotional determinations; and I mean them in the future as well as in the immediate present. As I talk here, and you listen, it might seem as if no action followed. You might call it a purcly theoretic process, with no practical result. But it must have a practical result. It can not take place at all and leave your conduct unaffected. If not to-day, then on some far future day, you will answer 
some question differently by reason of what you are thinking now. Some of you will be led by my words into new veins of inquiry, into reading special books. These will develop your opinion, whether for or against. That opinion will in turn be expressed, will receive criticism from others in your environment, and will effect your standing in their eyes. We can not escape our destiny, which is practical ; and even our most theoretic faculties contribute to its working out."

This development of all mental life toward practical activities is the most fundamental educational ideal which we have derived from the general doctrine of development. The place of reading in the development toward action will be obvious from a study of the way in which impression and resulting activity are related at different stages of development. The simplest case of activity, long before reading begins, is that in which impression passes at once into its appropriate reaction without even a word or thought intervening. This is the case illustrated when we start at a loud clap of thunder. Then come in order of their complexity, less direct forms of reaction in which we do not respond to the impression directly, but pass from impression to some suggested thought, some suggested image perhaps, and so on through this suggested thought or image to the appropriate reaction. This is the case when I hear a clock strike and think of my engagement and go to meet it. Indirect responses of this type come to be more and more elaborate in higher and higher development, and it is as an aid to such indirect reaction that language finds its great value. I see an object and think first of its name. The name suggests a further 
train of thought leading ultimately to action. The advantage of such a system of words is that some one else may often do the first stages of the reacting for me. The seientist sees the object and investigates it, and gives us the results of his developed reeognition of meaning in words, and we ean pass from words to the appropriate bodily response by following what he has put into words.

Words are of value only when they arouse something more than mere articulations; they must arouse ultimately reactions appropriate to their remoter meanings. So long as a word arouses an articulation as its only response it is an end in itself. It does not serve its highest purpose as a link in a ehain of indireet reactions. This is nowhere better shown than in the faet that as words become more and more familiar the mere articulatory activity is more and more reduced. The most familiar words tend to pass direetly into appropriate reaetions. Take sueh a familiar word as " high" for example. One feels himself tending to roll his eyes upward when he hears or sees the word. The intermediate steps of reeption of the impression, artieulation, interpretation, have all faded into relative insignificance, and the final act eomes without noticeable delay. This is an advaneed form of development and shows that the fusion between word and meaning has reached its most advaneed stage.

The line of thought which I have sought to bring out in this diseussion of the relation of action and meanings is so rieh in its suggestions to the teacher that it would require a whole volume to complete all the possible lines of applieation into which it leads 
us. Our whole system of modern education is getting at the fact that a real meaning involves direct contact with objects and direct manipulation of them. We try to give a child some reactions with which to build up these highest fusions with words, and we do well in doing this. Training which gives meaning to words is always practical training. Not narrow training in some single craft, but training in the broad recognition of our adaptive relations to the objects about us. And such training in the use of words is highly practical also in the possibilities which it brings to us of acquiring new indirect adaptations from our fellows.

The cultivation of this ability to receive adaptive suggestions indirectly is, let us repeat it, one of the highest stages of development. A very large part of the justification for the existence of our schools is to be sought in the necessity of bringing our children into full possession of language in order that they may borrow from the cxperiences of others and thus get knowledge indirectly.

The outline study of the process of reading which we have taken up, ought to suggest to you some of the yet unsolved problems. How are we to make the mechanical side of reading most complete without making articulation an end in itself? How are we to do our full duty in calling attention to the analytic work necessary for spelling and yet get at the synthetic processes as rapidly as possible? How are we to make language really productive as a means to adaptation? These are problems that we shall not solve satisfactorily until we understand the inner nature of the reading process. 
264 GENETIC PSYCHOLOGY FOR TEACHERS

It is with this group of problems then, that I leave you. Some hints we have had of their solution, but we need more study. More study on the part of individual teachers who see the meaning of the problems and then go forward to their solution. 


\section{CHAPTER IX}

\section{THE IDEA OF NUMBER}

THE use of numbers is quite as ancient as the earliest forms of writing, and may have been even earlier. Our word calculate and all the words from the same root, are derived from an ancient Latin word meaning pebble. This carries us back in thought to an early period when, instead of making the simple marks which were very early used in keeping tally, primitive man laid aside a pebble for each unit as he counted, and the pebble was his tally-mark.

Or again, as we study the names used by primitive peoples for their numerals, we find them bearing unequivocal testimony to the fact that men counted on their fingers long before they tried to mark down the results of this counting. Thus, a student ${ }^{1}$ of the Zuñi language tells us that the Zuñi word for one (töp'in te) means "take down to start with," that is, fold down the little finger; and the word for two (kwil-li) means "put down with," or put down the next one with the little finger. The Zuñis still count by starting with all the fingers stretched out and folding down one finger for each tally. They always begin with the little finger.

${ }^{1}$ Fr. H. Cushing, in Amer. Anthropologist, vol. v (1892). 
Their names for three, and so on, are of the same character as the names given, and indicate the origin of their whole system of counting from the hand. One hardly needs to recall that the decimal system which we follow, is evidence of the influence of the ten fingers in developing our own system before there were even primitive means of keeping tally. As a matter of well-known fact, our decimal system is by no means the best system that could have been devised if men had been mathematicians from the first. A better system would have been one based on twelve. Indecd, we have this system in our measurements of time and in our measurements of circles, both of which were borrowed, not from the natural system of kecping tally on the hands, but from the Babylonian scientists.

But while men used number very early, they never succeeded in carrying numerical processes to any very high degree of perfection until in comparatively recent centurics. The Egyptians had a most clumsy arithmetic. We are told that in order to add fractions, the Egyptians were obliged to raise these fractions to the denominator sixty, instead of to some simple common denominator such as we use. Even the Greeks and Romans had a very unwieldy system of notation. We are all acquainted with the Roman numerals. They can never be set down in columns to be added; and multiplication is a bewildering process if one undertakes it with this system of notation.

Even while number processes were thus at a relatively low stage, and while number notation was still very undeveloped, certain forms of practical application grew up which have always been of great importance 
in connection with the use of numbers. These lines of application consisted in measurement. Land measurement was one of the earliest forms of measurement, and the measurement of values involved in primitive barter early needed the assistance of number. Indeed, so intimate has been the relation between number and its application in measurement that some recent writers $^{1}$ on the subject of number have urged upon us as teachers the importance of recognizing this relation as the fundamental basis for our teaching of arithmetic. We cren have text-books prepared to illustrate how number may be taught through its applications to measurements.

It is interesting to notc in connection with this recent urgency for a measurement-arithmetic that the greatest measurers and the greatest geometricians among the early nations, did not, as a matter of fact, have a very highly developed science of number. The period of Euclid, that master from whose work we still borrow in our school text-books on geometry, was not a period of profound knowledge of arithmetic.

For our arithmetic and for those scicnces which deal with number, we have to wait until the dawning of the modern period. In the carly beginnings of the Renaissance, that period of the revival of intellectual life in Europe, we borrowed from the Arabian scholars, probably from the Moors in Spain, the system of numerals which we call even to-day the Arabic numerals. With the arrival of these numerals the history of mathematical sciences enters upon a new

1 McLellan and Dewey, The Psychology of Number. 
period. And the interesting fact about the Arabic numerals is that their value consists, not in their more immediate applicability to measurement, but rather in the presence of eertain characteristics which favor the development of easy processes of manipulating number relations. It was the expression of certain distinctly numcrical relations whieh gave our modern arithmetic its start.

You are doubtless familiar with the essential superiority of the Arabic numerals over the Roman numerals. Every value has in the Roman numerals a separate symbol. In the Arabie numerals, we have a fer symbols placed in different positions to express different number relations. The likcness of the Arabic symbols in various positions shows immediately that the possible processes or modes of treatment are the same whether the symbol is in unit's plaee or in thousand's place. The simplification of numerical proeesses which results is very great, so great indeed, that all our modern methods of manipulating number relations depend upon this essential faet. Thus, to take a eoncrete illustration, suppose we represent five hundred fifty five by Roman notation. It will be DLV, eaeh five being represcnted by a symbol of its own. If one were going to multiply DVL by five it would not be obvious on the faee of it that the numerieal proeess is the same in the case of eaeh of the three terms of the number. How obviously the proeess shows its eharacter when, as in the Arabie notation we use 555 . We see now that whether in hundred, or in ten, or in unit, place, the five means the same process of multiplication.

This suggestion from the history of arithmetic 
that there are certain purely arithmetical relations, scems to me to be most fruitful for the teacher to follow out and I shall ask you to inquire more in detail into the nature of a simple arithmetical process. Let us begin, as we have all along been doing, with the developed consciousness of the teacher.

Take the simple process of addition, $7+5=12$. In some sense or other we place seven and five as identical with twelve. But after all, seven and five are rccognized as not identical with twclve. If seven and five mcant exactly the same thing as twelve, then there would be no motive for talking about them as in any sense distinct. So we sce that our cquation $7+5=12$, comes to be an expression of identity with a recognition of the fact that the two sides of the equation are not fully identical.

The kind of identity and difference which are here united will be obvious, I think, if we will recognize that twelve means one way of arranging a certain collection of objects, and seven and five mean another way of arranging these same objects. The identity consists in the fact that the objects dealt with all along arc the same, and the difference appears in the mode of arranging the same objects. Lct us try to express this equation $7+5=12$ in other terms. We may do so as follows: here are certain objects, wc may arrangc them in two unlike groups, or we may put them all together in one group. Or again, we may say, here are certain objects which are in two small unlike groups, let us put them into a single group when we shall have exactly the same objects, but a different arrangement. It makes no difference for our thought whether these 
processes of varying arrangement are actually carried out or not. The important consideration is that we shall think all the objects together in one case and in another case we shall think of them as not altogether, but in two separate groups.

This idea that number equations express different modes of grouping, can be carried also into the examination of any single number. Take five, what does it mean? It means that we have for some reason thought of one, and one, and one, and so on up to five, as bclonging together. It makes no difference whether the things are actually together or not, we may think of them as together. Every time we count up a scries of objects wc put them together in a group. 'This appears in an interesting way if we inquire into the meaning of the word five as we use it in counting. We arrive at a certain object and say five. Our attention is chiefly on the object, but it is also in some measure on the objects which have gone bcforc, for the word five refers, not only to this object at which we are now looking, but also to the whole group up to this point. Indeed, so strong is the group idea in the word five that we have in our modern language developed a word with which to designate more specifically the position of the object in the group. We call this derived word an ordinal numeral and we speak of the fifth object.

Follow out the line of discussion in any direction you please and you always come upon this same fundamental fact, that numbers express modes of grouping objects. Thus, take the process of subtraction as expressed in the equation $12-7=5$. The fundamental 
operation of grouping is here approached from a somewhat different point of view than that adopted in the equation of addition. This equation of subtraction calls attention to the fact that given a group of twelve objects, we may break the given group into two lesser groups, one of which is specified as seven. After seven are withdrawn from the larger group of twelve, a group of five still remains.

We all know how far this process of regrouping seen in subtraction may be carried out as a merely ideal process, in the fact that we ultimately come to apply the process of subtraction to cases where it involves us in curious complexities. Thus, suppose we have seven objects and some one demands of us that we give up a group of twelve. This is essentially a process of subtraction. $7-12$ is the way in which the process is to be expressed. Now as a matter of actual transaction $7-12$ is an absurd demand. As a matter of thought, on the other hand, it is quite reasonable. Given seven things with a demand that we produce twelve, we see at once that there is a deficit to be made up somewhere else. We ascertain the amount of the deficit which is five, and we indicate the amount by using the ordinary numeral 5 , and we mark it as a deficit by giving it the sign which shows that it is to be withdrawn from somewhere else. The result of all this thought is that we say $7-12=-5$. 'This negative quantity expresses something that does not exist as a reality, but is demanded in thought. For our thought about processes it is a perfectly clear conclusion.

It will be seen that the processes of addition and 
subtraction are, aeeording to this explanation, nothing but different phases of the general proeess of grouping. Addition means building up larger groups from smaller. Subtraetion means breaking up larger groups into smaller. Both addition and subtraetion belong to the fundamental proeess of making up groups.

When we come to multiplication and division we have modifieations of the process of grouping. The natural step to these proeesses of multiplication and division is not through multiplication, but through division. I believe that we shall eome to reeognize this some day in our school practise. Be that as it may, the kind of grouping present in both division and multiplication is to be defined by saying that the smaller groups inrolved in these processes are always equal to each other. Thus, when we subtraet seven from twelve and get five, there is nothing about the two smaller groups seven and five, to lead us to compare them, except the general fact that they are unequal. But divide twelve into six and six, and the process proves to be an especially interesting ease of subtraction. Here is a ease of subtraction in which the two lesser groups are equal. Division is therefore a special case of subtraction. The character of the groups obtained by division into equal groups, leads to our development of a genuinely new mode of thought. When the groups are alike we begin to count the equal groups as single wholes, thus treating eaeh group as a unit of higher order. Thus, when we say there are two sixes in twelve, we have said there are in twelve two units of higher order. If you ask what makes up eaeh of these units of higher order, we answer six units of the lower order. 
Division and multiplication thus eome to be processes dealing with units of higher order.

There is another way of getting at this truth about division and multiplication. We all know how intimately the processes of multiplication and division are connected with the general fact that our whole system of notation is a decimal system. One can multiply by tens without any difficulty. Multiplying or dividing by ten is just like counting. Did you ever realize that this is due to the fact that ten is, in both counting and multiplying, a standard unit of higher order?

Think of the matter in this way. You are eonfronted with a large group of objects, say a hundred or more. The group is so large that you can not manage it well as a whole, and the individuals are so numerous that you can not treat them satisfactorily as individuals. What do you do? You do the most natural thing in the world, you break up the unwieldy whole into certain groups that can be managed. From the earliest times men have divided up armies, and cattle, and lands, on just this principle. Each smaller group is then treated as a unity of higher order. Thus, the small companies of the army were all given a responsible commander. He represented the unity of the whole group. Rations were given to him for the whole group. We have carried this same idea of dividing into eompanies into our eounting. When we have a mass of objects we eount one, two, and so on up to ten, and then we stop. We set aside that ten as a manageable group, as a unity of higher order, and then begin again.

The fact that ten is a unity of higher order, is expressed in the very fact that we label it with the same 


\section{$27 \pm$ GENETIC PSYCHOLOGY FOR TEACHERS}

symbol as that which we use for the lower unities. We merely mark the higher order of the decimal group by giving to the digit when it expresses a unity of higher order a higher position.

When now, having arranged our great mass of objects into tens, we begin to count by tens, we do exactly what is done in every process of multiplication and division. We treat small equal groups as unities of higher order. That is what makes multiplying by tens so easy. The reason why multiplying by threes or fours or other numbers than ten is not so easy, is, that having adopted a standard group of ten for our whole notation, everything else has to be turned into terms of this standard notation. The ordinary multiplication is therefore, a double process; it is treating small equal groups as unities of a higher order, and then turning the results into terms of our standard decimal notation.

Without attempting to carry the discussion into any further detail, we may conclude that there is such a thing as the science of grouping. The objects which are grouped, are not centers of attention in this science, but rather the different ways in which the grouping may be carricd out, no matter what the objects are. That two groups, one of seven and one of five may be made out of a single group of twelve, is a fundamental fact of the science of grouping. This is not a fact of nature-study or history or literature, it is a fact that deserves to have independent recognition. It is a fact of the science of number.

I have no patience with the efforts being made in so many departments of our education to swallow up 
such subjects as arithmetic into some other subject. By no means in the world can the fact that $7+5$ $=12$, be taught except through a definite and wellordered directing of the attention to a fact of grouping. It makes no difference how much you dccorate the fact with outside frills, the fact will have to come out sharply and clearly as a fact of importance in its own right.

One of the sad results of our prescnt-day efforts to evade arithmetic is that we get neither the other subjects we seck to reach nor the arithmetic. I once saw a teacher in one of the most widely known expcrimental schools in the country, illustrate very clearly the mistake herc referred to. She was teaching a beginning class in social relations and was "incidentally" teaching number. For her own thinking the number expressions and processes were obviously the most important facts involved. So absorbed was she in number that she allowed a youthful storekecper to sell a large well-bound book for ten cents and an unbound pamphlet for seventy-six cents. She then allowed the pupil who next in order of rotation became storekceper, to buy back the ten-cent book at the ruinous price of sixty cents. In short, she forgot entircly the commercial relations; and the children, not being controlled by any deep-seated motives of cither commerce or aritlmetic, lost all the instruction that might have come from an intelligent pursuit of cither of the relations alone.

Another difficulty with our teaching of arithmetic when we fail to recognize the fact that arithmetic is a science of grouping, is that we take up a whole serics 
of subjects in arithmetic and think we have treated them adequately in arithmetic, when, as a matter of fact, they, as wcll as the science of grouping, ought to have independent trcatment. For cxample, most of us learn the greater part of what wc know about spatial rclations, not from the spatial values themselves, but through the abstract numerical expressions of these valucs. The result is that we are deplorably deficicnt in ability to think in terms of rcal spatial relations. We can talk very glibly in number terms of ten feet and half a mile, but we do not think these values in spatial terms at all. Even smaller distances, such as eight inches and five centimeters, have little concrete meaning for the ordinary mind. Systems of form-study are fortunately bcing worked out to correct this defect in our educational system. But form-study is distinct and different in its motives from number work. The two must not be identified. Note that it is not for a moment asscrted that the two kinds of study may not be advantageously combined at certain stages. But it is asscrted that spatial relations are not identical with number relations and must not be confounded with them.

I agree heartily with Mr. Speer in his criticism of the blind mixture which we make of number and measuring. He writes in his Primary Arithmetic ${ }^{1}$ as follows: "Place a measure in the hands of a pupil and set him to marking off spaces on this or that, and counting them bcfore he is ready for such work, before anything has been done to induce the habit of looking from one magnitude to another, and you absorb him 
in a mechanical process which turns the thought from the relational elcment with which mathematics deals. He may write, 'the door is eight fcct high,' when he has simply countcd eight spaces. But he has madc no mathematical comparison, observed no relation, done little which develops power to think."

I should be willing to subscribe to an extension of this criticism over most of the departments of our arithmetic. The great trouble in teaching percentage or fractions, or other departments of arithmetic, is that we are doing two things at once and commonly not doing either one fully. We are trying to teach certain practical relations of life such as business relations, and we are at the same time trying to teach number relations. We do not seem to realize that the number relations are not identical with the business relations. We do not secm to understand that a problem in interest, for example, involves a human relation which is not arithmetical at all. As a matter of fact, I doubt very much whether the majority of our children have the vaguest notion of what the meaning of interest on moncy really is. They always think of interest as a problem in number.

What I have said about the difference between number relations and spatial and busincss relations can be emphasized, I think, by calling attention to the fact that there are ways of dealing with spatial and business relations that do not involve any number. For suitable examples, we shall, of course, have to appeal to cases in which training has been of a different type from our own. Such examples are numerous, however. Take any savage who has not had a course in number, 


\section{GENETIC PSYCHOLOGY FOR TEACHERS}

but has had a very thorough course in spatial relations. He can shoot his arrow or throw his spear with a nicety of spatial estimation that surpasses a hundredfold his ability to count. He knows at a glance whether an object can be reached sooner or later than another object. He knows how much higher the highest rock is than the one below. But he never translates any of his knowledge into number. His number relations lag far behind his spatial ideas. Now note that this does not show for a moment that spatial apprehension should always precede number expressions in individual development, it merely shows that spatial ideas have a rcality and value which is peculiar to themselves. They are spatial quantities, not numerical quantities. The use of number in connection with these spatial quantities as we teach it in our schools, is not necessary, it is not universal, it is not a sufficient justification for the confusion of the two which usually takes place.

Again take the relations treated in that part of our arithmetic which usually deals with buying and selling. We are constantly buying things in practical life, that is, in technical language, we are securing goods of various kinds in exchange for the precious metals. In such transactions we use number calculations so constantly that we have come to look upon the buying process in our school treatment of it as entirely mathematical in character. But there is an important distinction to be made between the number expressions used in buying, and the end for which the number expressions are employed. The real relation involved is one of relative desirability of the goods in the eyes of the various parties to the transaction. That is, the 
real relation in commerce is illustrated in its simplest and purest form in the barter of the savage. He has one commodity and wants another, so he makes an exchange. Some day his descendants will use gold and silver and they will state their desires in terms of figures, but their essential act in buying will continue to be one of exchange.

This fact that the number idea is not identical with spatial ideas or with ideas of valuc, but is equally applicable to these different sphercs of quantity, is what makes the number idea an abstraction. Therc is a good deal of vagueness in many minds about the meaning of the word abstract. We recognize in a general way that number is highly abstract, but do not know exactly what this highly abstract character consists in. Let us see if we can make the matter clear.

We have a certain group of objects lying before us; to be definite, let us assume that we have twelve coins. We may make a great many different kinds of real groups out of these twelve coins. For cxample, we can, if we wish, hold 5 in one hand and $\gamma$ in the other. Such a division of our twelve coins into two groups is a real division, or as we say, a concrete division. There is nothing abstract about such a process.

Now take the first step toward abstraction. Let the twelve coins lie together on the table, and with your eye draw a purely imaginary line through the group of twelve, dividing it into two groups, one of seven and one of five. Here the objects are concrete as before, but the division is a purely ideal division, real only for the thinking individual. This possibility of making purely ideal rearrangements of the objects about us 
is one of the first steps in the growing independenee of our thought. We begin to realize the fact that there is a difference between objects and our mode of arranging them. We begin to see that we are the really important faetors in the process of arranging. We can think of a eertain arrangement whether it is aetually earried out or not.

This faet that the mode of arrangement belongs to ourselves rather than to the objects may be made elearer in this way. Suppose I begin pointing to the various eoins in my pile of twelve. I point first with my right index-finger and keep pointing with this finger until I have tallied off five of the eoins. I ean now turn about and point to the other seven with my left indexfinger. I had a series of aetivities arranged in two distinct groups, one of five and one of seven, and the coins were in no way disturbed by the classification which I introduced by dividing them into right-hand coins and left-hand coins. The proeess of arrangement was my own. I tallied off the eoins as I pleased. It may be that the coins were not mine or were quite beyond my power, but the arrangement was fully in my control. If I please I can at another time, point to nine with my right index-finger and to three with my left. Or I can point to all twelve with either right or left finger.

This is the first step in the proeess of abstraetion, to realize that the mode of arranging objects is quite independent of any eonerete redistribution of the objects themselves. There is no reason, for example, why we slould not point with our left finger to all of the desks in the selioolroom and then point to all the 
window-panes with our right finger. And there is no reason, on the other hand, why we should not point to both desks and window-panes with the same hand. The notion that number depends on some kind of uniformity in objects is all false. Some writers tcll us that only like things can be counted together. This is sheer nonsense. We can count anything we like together. We are the ones who do the counting. Counting is an individual process. We can control it without refercnce to outside difficulties of arrangement. When the process is devcloped in its higher forms, abstraction, or freedom from particular objects outside of ourselves, becomes complcte.

I have used the illustration of pointing so as to get some definite and obvious form of personal activity. Of course, we can count without pointing, and we can distinguish groups without using the right and left sides. The division is easy enough when we are trained in counting, because we have different actions of the rocal cords for each individual object we count. We have already seen in our discussion of reading that word ideas always arouse certain activities in the vocal cords. This involuntary expression accompanying thought processes is nowhere more strikingly manifested than during counting. Each new object which we include in this or that group, is literally pointed out, not by a finger movement, but by a distinct response of the vocal cords. Thus, we see the truth that number arrangement is a process of individual activity, confirmed in a very literal sense. Even in its most abstract forms, number is related to individual activity. 
We have said that the individual after acquiring this ability to use abstract number classifications may apply them as he likes. There is, however, one limitation to the free manipulation of his rearrangings, which we must notice. The individual is not at liberty to be inconsistent with himself. For example, I can not arrange a certain series of objects in my thought and call that serics five to-day, and to-morrow call the same scries elcven. To put the matter in another form, I can not point in a certain way to-day and in a totally different way to-morrow, and then treat the two cascs of pointing as if they werc the same. If I do I shall get into trouble. I shall find that inconsistcncy will be my undoing. The one thing that I must learn about this mode of arrangement which I cultivate is that it will be necessary for me to be consistent.

Some of the means by which the race has slowly worked out a series of helps to consistency are obvious. For example, suppose that instead of pointing time and time again with the index-finger-a form of movement which might easily lead to confusion and inconsistency -we point successively with thumb, index-finger, middle finger, and so on. Then we should be able to mark a given stage in the process of counting by the part of the hand that has been covcred. This is exactly the sort of counting process which we sce devcloped into written form in the Roman numerals. Again, when it comes to using activities of the vocal cords instead of finger movements, consistency is sccured by developing a certain fixcd order of vocal cord movements. The fixed order is learned and adhered to whatever the subjects of the arranging activity may be, The 
children of a developed race have the advantage of racial experience in this matter, for they find a fixed order of vocal cord movements all prepared in the racial series of names for numerals.

More important even than consistency in the counting of relativcly simple groups, is the devclopment of the power to be consistent in the combining of thesc groups in various ways. Suppose that we have a group of three and a group of four, we may rearrangc these two groups in a variety of ways. But in all of the rearrangements we must be consistent with the first grouping into thrce and four. This may be expressed by saying that whatever we do with these two groups, we must always be able to come back to the original groups instantly and without contradicting ourselves. This necessity of always being able to return to the original form, leads us to study the rules of consistent arrangement. Anything that is consistent with a return to the original grouping is permissible in our handling of three and four. The study of what is permissible or consistent is the study of number rclations. Do you not see that when I say 3 plus 4 cqual 7 , equal 5 plus 2 , equal 6 plus 1 , equal 4 plus 3 , and so on, I am merely working out all the various consistent statements that can be made about three and four?

There is no difficulty in understanding now why the science of mathematics is so closely related to what we call logic. Logic is the science which studies the modes of consistent reasoning in all departments of thought, and mathematics deals with consistent modes of dealing with group relations. The reason why we have to have a science of number is that it takes much 
investigation in many directions to make sure that our modes of ideal regrouping are really eonsistent. It would be uneeonomical for every individual to seek out all the different consistent forms of number arrangement, so the raee has reeorded what it knows about various modes of eonsistent reasoning, in the seience of number relations, and the individual gets the benefit of all this aecumulated experience.

Let us now ask ourselves, on the basis of our study of arithmetie as the seience of groups, what the proeess is when we work out a practieal problem by the aid of our mathematieal prineiples. The practieal problem presents to us certain faets arranged in certain relations with respect to eaeh other. Our first step is to understand the given arrangement of the faets, and the second step is to express these relations in terms of our number system. This second step is not always easy, when the relations are eomplex, but upon its aeeuraey and eompleteness depend all the later steps of the operation. It is just at this point that there arises one of the great diffieulties whieh our pupils have with the eomplex problems we give them in arithmetie. They frequently do not understand the nature of given relations and they do not know how to formulate the problem in terms of the number system. When sueh diffieulties arise in the very first stages of an example, where is the remedy to be sought? In a more thorough comprehension of number relations pure and simple? Certainly not. If the pupil has difficulty in understanding the problem in its first stages, what he needs is some explanation of the real faets involved. He should understand the situation first in its ordinary 
terms. Then he should have some training in the means of expressing these real situations in terms of the purely numerical relations.

After the second step of intelligent statement of the problem in terms of number, the rest of the process falls within the domain of the science of number relations. We know through this scicnce how to rearrange and manipulate the relations, always kccping ourselvcs consistent with the original facts. Thesc manipulations do not affect the real facts one way or thic other. They simply show us what would rcsult if the relations werc consistently rearranged. It does not make any difference what the facts are aftcr they are once translated into the number expressions, from that time on we are interested only in the consistent rcarrangement of the rclations with which we started.

It is quite possible to start with rclations that are entirely prepostcrous so far as the real world is concerncd. One may start, for example, with ten houses costing fifty cents each. It makes no diffcrence so far as the consistcncy of the process is concerned whether one can or can not reasonably make the assertion with which he starts. But from the point of view of intclligent education it is a mistakc to misrcpresent the real relations even where we might neglect them without danger to our science of numbcr. The science of number as such may not suffer, but the pupil's notion of what an application is, certainly suffers. The number process may be the same when based on an absurd proposition as when based on a reasonable assumption, but there is always a loss in the character of any men- 


\section{$2 S 6$ GENETIC PSYCHOLOGY FOR TEACHERS}

tal process when it eontains an absurd element, even though that element is of secondary importance for the study of number relations.

The significance of this statement which we have just been making, that the best edueation ean never be obtained by starting with absurd propositions, is wider than most of us imagine. Do you ever realize how absurd it is to tell a child to suppose that he has a thousand dollars in the bank? Most of us would have to think two or three times to rise to any very vivid realization of such a state of affairs in our own mature minds. To the child it is no real application of arithmetic to life to give him such a proposition. We mistake if we think that there is anything enlivening in such a proposition. As a matter of fact the mind simply passes as rapidly and as fully as possible over the absurd proposition and gets at the number process involved. The ehildren soon get used to accpting absurdities without much thought about them, and our whole seience of number gets to be a kind of vague mixture of more or less remote and senseless propositions and half-understood number rules. Through this maze the children are carried, wondering now and then that numbers seem to fit each other so well, and wondering somewhat less frequently that men in the arithmeties live such fanciful lives. But worst of all, losing all the time, what they should be gaining, an idea of the real utility of their science.

It is not to be wondered at that we feel sometimes the inadequacy of our number work. It is not to be wondered at that business men and practical men condemn our methods in the sehool. The trouble with us 
is that we have no clear notion of what we are doing, or of the end at which we are aiming.

And now I suppose you are prepared to ask how all this discussion is to be turned into practical school work. I am tempted to make short work of your question by saying that it is your business and not mine to turn this into practical school work. I believe I should be justified in disposing of the matter in that way. Indecd, I can think of nothing which would be more opposed to the whole spirit of my discussion, than for me to formulate for you a fixed system of arithmetic teaching. Arithmetical knowledge does not consist in a scries of rules or examples. It consists rather in a growing comprehension of the consistent methods of treating number relations, whenever and wherever these number relations appear. If that sort of knowledge is to be taught to children, there must be a living teacher who can help the child with his special difficulties. The child's difficulties do not appear in accordance with any fixed system that was ever written. The teacher who does nothing but follow some set system is not going to succeed in helping children where they need help most, and when they need it most.

There is another rcason why I shall not take it upon myself to lay down any new system of arithmetic teaching. If the analysis of the number idea which we have been working out is valid, if it agrees with your own study of the mature number ideas which you find in your own minds, then the principles of teaching to which we sliall be lead by this analysis arc applicable to all the existing systems of teaching arithmetic. When you find a man who has to change the whole system of cduca- 
tion in order to fit some of his ideas, beware of that man. No man can impeach a nation. No man can impeach our schools. They are the products of centuries of development, they represent something vastly broader than the individual. There is something worth retaining in every system of teaching that has been followed in the schools. And so now we may say that whatever system of arithmetic you teach, you can teach it more intelligently and with better results, if you will make yourselves intelligently familiar with the fundamental nature of the number idea. Indeed, we may boldly venture the assertion that it is only through sueh a clear understanding of the nature of the number idea that you ean teach arithmetic in any other than a blind non-rational fashion.

Such practical suggestions as I have to make, therefore, are intended to fit the system which you teach, whatever that system may be. The first suggestion is that in teaching arithmetie you should never lose sight of the main purpose which is to give instruction in number relations. Do not let this ehief purpose beeome obseured through your interest in the illustrative examples which you may have occasion to use. Do not fail to keep in mind the fact that the examples are examples, and not the chief subjects of attention.

You have heard some of those tedious talkers who begin to give you an aeeount of something and are distraeted from the line of their narrative by a hint which eomes up in the course of their talk. They lose the point of the story and they lose the advantage of the seeondary line of diseussion as well. The same thing is true of the sort of false eorrelation which we some- 
times see practised in arithmetic. The lesson starts out bravely as a lesson in arithmetic, but it gets eonfused by its own illustrations, and at the end of the period it is neither arithmetie or anything else.

The only true principle of correlation is to have one main line of interest at a given time and cluster examples about that main line, never for a moment allowing the chief consideration to be lost sight of. At some stages of school work the only way in which it is possible to maintain sueh a clearly defined line of thought and work is to give relatively little in the way of distraeting illustrative thought to be mastered. In the early grades of school it is not well in a single day of school work to approach the same object from too many points of view. Let the children have a fair opportunity to beeome acquainted with one aspect of a situation before you thrust another upon them. If it is an example in arithmetic, the objeets should be simple, and should be chosen for their availability to illustrate as simply as possible the facts of number relation.

We shall never eeonomize time in our school programs if we fail to recognize this fundamental principle of arrangement, that certain lines of instruction have at times the right of way. It is only by arranging arithmetie with referenee to the demands of arithmetic, that we shall ever get over that subject eompletely. How long do you suppose one would have to wait before all the possible number relations came up "incidentally" in connection with a course in manual training? Almost indefinitely. If we want our arithmetic to be in any sense of the word complete, we shall have 
to force examples into the course at times for no purpose other than to give a complete view of number relations. The tcaelier who does not recognize the right of arithmetic to be taught as the main line of consideration, and to be taught at times in a forced way, is simply turning baek from the rationalized order of sehool training to the purely aceidental order of the natural environment.

Of eourse a child ean get training by the purely incidental method, but it is like the training of the savage. Such training is never complete. The training of the street gamin is also of this type and it is never complete. Within the limits of their natural experience, savage and street gamin may be ever so acute, but their unsystematie training has never prepared them in an all-round way for a full, broad grasp of any subject. A full, broad grasp ean come only from taking up sooner or later a systematie, rather than the purely natural, order of study. Our arithmetie of to-day is suffering in some quarters from a giving up of the idea of completeness. We are too often satisfied to deal with those number relations which appear incidentally rather than with all the number relations in their completeness.

There is, of eourse, a sort of seeking after immediate eompleteness which is absurd. The old Grube method which aimed to treat every possible phase of a single number before passing on to the next, was mistaken in its devotion to sueh immediate completeness. Completeness does not mean that the child shall go through a subjeet at one sitting, or in the absolutcly logieal order. Let the order be flexible so far as it ean be, but let the teacher be ever aware of the need of 
making this flexible order ultimately eomplete. If the teacher will hold the situation clearly in mind and will resolutely set out to make the work in arithmetic lead to eompleteness of training in number relations, the path to that eompleteness may be varied by this or that reasonable bending. The warning whieh we need these days is not to get out of sight of the main line of training. Do not forget that there is a body of number relations and that these are worth teaehing.

The second suggestion whieh I have to make is one whieh I realize is out of harmony with some of the seemingly general tendeneies of the times. But I shall nevertheless venture the suggestion, and you shall judge of its soundness. If it be true that the raee has found it advantageous to establish eertain fixed orders of counting; and if it be true that the race has spent a great deal of time in discovering eertain series of eonsistent relations; and if it be true that the ehildren need to have these series of established relations firmly fixed in mind-then there is nothing whieh we as teachers ean do to make a royal road to all these possessions which the raee offers the ehild. The ehild must exert himself to aequire these fixed orders and these diseovered eonsisteneies. The ehild must be drilled into line and must learn to mareh aecording to the rules of the ar'my. If he is not drilled, he may learn how to straggle along by himself, but he will never get the full advantage of his social inheritanee. All this means that some of the faets of the seienee of number have to be made automatie by diligent and long-eontinued practise. We shall have to give up our bright dream that the hard ways of sehool life ean be made casy. These ways may 
be made less difficult perhaps by judicious preparation and by careful subdivisions of the task to be completed. But the work of lcarning consistent number relations as they appear in the multiplication table, for example, can ncver be escaped.

The third suggestion which I have to make is that the teacher will never find a better opportunity to cultivatc the power of abstraction or to study the development of that power than in the teaching of arithmetic. Like all abstract thought, arithmetical thought must be based upon concrete experiences. We can not cxpect the children to acquire the control of highly abstract modes of thought suddenly. There must be a gradual detaching of the process of thought from the particular objects to which the thought is applied. We have been working at this problem in the past without recognizing always just what we were doing. Our method has been to apply a given process of number manipulation first to one concrete situation and then to another, depending on the child's mind to arrive ultimately at a kind of general mode of thought. We have too seldom directed the attention of our pupils to the processes themselves. This ean be done, however, very successfully, even at an early age. Thus, one can lay a group of blocks before children in even the first year and ask them to think how they could divide them into groups without actually making the division. Then onc can go a step further and ask the children to close their cycs and think how they would divide the blocks. To bc sure, this is not a very high degree of abstraction, but it is abstraction begun. I think the true value of the Speer method is not in what Mír. Speer calls the 
ratio idea, so much as in the fact that the children have to think divisions into the blocks whcre there are in reality no divisions. Whenever you teach a child to think a division where there is no division, you have taken a step in the direction of cultivating his power of abstraction.

The training in abstraction must not stop at these early stages. A form of number manipulation which is sufficiently freed from the objects to be transferred to the fingers, is not yet fully developed, as we all know from our recognition of the evils of the counting-onthe-fingers method. Nor is abstraction complete when every problem of number relations has to be thought out in terms of any concrete objects other than the fingers, as for example, blocks. The watchful teacher who uses the Speer method, knows that the time comes when the next step in abstraction means the freeing of the children from even the blocks. The number processes must stand out by themselves. This is what accounts for the pause in the derclopment of children trained by any of the concrete methods. They come to a certain stage of development where abstraction is necessary for further progress and then the inevitable mental struggle has to be made to pass on to the higher processes.

If some teacher would make it his spccial study to find out how children can be assisted in cultivating the power of abstraction, he would perform a great service for the science and practise of education. There have been a good many theories of abstract thought in psychology and none of them seem very helpful to the teacher, and about all that we do now in a practical way. 
seems to consist in keeping ehildren at various examples and in waiting for the abstraction to work itself out. Perhaps we may learn some day how to eall the attention of the children more to the process itself. For example, I think even in such advanced problems as interest, we might advantageously take a little time to show the children that the fundamental combination of processes is the same whether the base and rate be given, or the base and interest. At the more elementary stages of the study, we should similarly make a distinction between the conerete factors and the fundamental relations. One method is that which I described a moment ago of thinking out divisions without actually making them. But in any ease, abstraction is not easy for the children, and we must make some effort to help them in earrying it out. Let us see if we can not gather some new observations on this subject so that we may do more than throw the ehildren blindly on their own resources in this difficult matter.

We must close this diseussion of arithmetie with these general suggestions. They are all of one type. They all center about the fundamental pedagogieal principle which it has been our aim to illustrate in each of our diseussions. That fundamental pedagogieal principle is that the teaeher should first understand the inner nature of his own mental processes and seek in his own understanding of these processes the methods of teaching. It is futile to study children unless we undertake the kind of study which the biologists eall eomparative study. Comparative study eonsists in taking various specimens illustrating different stages of development, and comparing them so as to find out their 
likenesses and unlikenesses. This discovery of the likenesses and unlikenesses, gives the only true basis for an understanding of the process of devclopment. A study of child life without an application of the comparative method is a veritable groping in the dark. It has no sure footing and it lias no definite outcome. It has no sure footing, for we do not know whether or not extcrnal expressions of the child mean what our external expressions mean. It has no definite outcome, for our study of children can never be undertaken with a view to keeping children at their present level. We want to elevate and develop them. And before we can answer the question of what we want to elcvate them into and develop them into, we nust study the higher as well as the lower stages of mental development.

'There is a passage in Wundt's Outlines of Psychology which I shall quote to you in closing, for it states the case with all clearness and with the high authority of one who is undoubtedly one of the leaders of scientific thought in our day. Wundt writes:" "For these reasons it is an error to hold, as is sometimes held, that the mental life of adults can never be fully understood except through the analysis of the child's mind. The exact opposite is the true position to take. Since in the investigation of children and of savages, only objective symptoms are in general available, any psychological interpretation of these symptoms is possible only on the basis of mature adult introspection which has been carried out under experimental conditions. For the

1 Outlines of Psychology, second English edition, p. 330. 
296 GENETIC PSYCHOLOGY FOR TEACHERS

same reasons, it is only the results of observations of children and savages which have been subjected to a similar psychological analysis, which furnish any proper basis for conclusions in regard to the nature of mental development in general." 


\section{CHAPTER $\mathrm{X}$}

\section{SOME LIMITATIONS OF OUR NATURE}

IN this last chapter I shall bring together several miscellaneous topics which should be included in our teacher-study, and shall also review briefly the ground which has been covered in the earlier chapters. Our present task is to gather up the loose ends and main lines of our thought so that we may secure a general grasp of the nature of teacher-study and may carry away some clearer recognition, I hope, of the importance of continuing this study in every-day class-room work.

For want of a better title for these miscellaneous topics I have called them all, discussions of the limitations of our nature. That may sound like a rather discouraging subject with which to close what has aimed to be throughout an optimistic view of school life; and it would be a discouraging subject if there were not means of bridging over these limitations. I believe there are such means, and that is why I shall call your attention to these particular limitations. If there are other limitations of which any of us are conscious and for which no means of correction are in view, let us consider them in secret. In public we shall think only of these limitations which can be overcome.

The first limitations of the tcacher's nature which 
are important for our consideration are those which grow out of the fact that we, and all our ancestors, were originally made to live outdoors where the air is free, and the ranges of vision are long, and the light is strong and well distributed and shaded by the soft colors of nature. We are not in our natural environment when we find ourselves shut up in small closed spaces which are insufficiently ventilated and lighted, and where we are set about accomplishing confining tasks.

Take for example, the means which nature has given us of testing the air we breathe. We call it the sense of smell. This sense of smell is nature's sentinel at the portal of our lungs. Any foul gas which should not pass this portal is challenged by the sentinel and a general alarm is sent to headquarters. But the poor sentinel finds himself quite unable to cope with the hard tasks set for him in the schoolroom. Have you never come into a badly ventilated schoolroom from the fresh air of outdoors and noticed at once the warnings given by your sense of smell? But stay in that room a few minutes and the protests grow fainter and fainter and finally you breathe the foul air without any consciousness of its impurity. If you had been in the room from the early morning, and the air had gradually grown impure, it would have been quite impossible for you to notice the gradual process of deterioration. Nature's sentinel at the portals of the lungs is a very imperfect guide in the artificial rooms in which we live. If we lived in the open air where changes are of no importance unless they are sudden and marked, it might be different. But nature can not makc a man suited for the outdoor conditions of life and yet have 
him suited to artificial indoor life as well. What is to bc done in such a case? Obviously, there is only one course to follow. Recognize the limitation of one's nature and prepare to meet it. If you can not depend on your sense of smell to tell you when a room is filled with impure air, then adopt some other safeguard quite as artificial as the room itself-get a ventilating systcm.

The trouble with most of us is that we are not convinced of the limitations of our natures. It seems to be uscless to produce statisties. That has been done time and time again and has proved beyond the shadow of a doubt that the ordinary teacher, in any schoolroom not provided with adequate means of ventilation, is breathing impure air and is allowing the children to breathe impure air. I think the most convineing argument which could be brought to bear on most teachers would be to have them go outdoors for a short recess each day in the winter just before school is out, and let them come back with their natural air-testers in condition to act for a short time in an artificial environment, and let them in this way get an individual realization of the air they had been breathing all day.

Or turn to another illustration and note how nature was limited in the production of a natural thermometer. Suppose you felt the cold of a winter day as keenly all the time you were outdoors as you do when you first go out of a warm room. The cold of a winter walk would be simply excruciating. As a matter of fact, nature has arranged our temperature scnse in such a way that we soon get adapted within wide limits to the surrounding air, and do not feel cold and warmtl 
exeept when there is a sudden or extreme inerease or deerease of the surrounding temperature. You do not feel cold on a spring day when the temperature is $60^{\circ}$, nor hot on a summer day when the air is $80^{\circ}$. The skin has adapted itself to the surrounding air. The seientist expresses this faet by saying that the skin has a fluetuating or adaptive zero. This skin zero goes up or down within wide limits with the atmosphere, and we do not notice anything but sudden ehange above or below the skin zero. The praetical applieation of all this you know. The teacher forgets about the temperature, and his sense of temperature does not warn lim, and the temperature gets up above $80^{\circ}$. The result is that everybody gets restless, and work does not seem to be easy-all beeause nature could not make us into good thermometers and at the same time fit us to be eomfortable in the various temperatures in whieh we have to live at various times.

Take still another limitation of our natures. Nature did not give us any sense at all with which to reeognize ehanges in the amount of moisture in the air. Most of us never know, exeept in extreme eases, anything about humidity. We know it is humid when everything is damp, and matehes will not light; and we know it is dry in rooms where furniture warps and craeks; but we do not know about the lesser ehanges, and we do not recognize any of the changes direetly through our senses. And yet there is many a day when the throats and mueous linings of our pupils are suffering from the parehing of the dry air of the sehoolroom. Nature expeeted when she made animals and men to live out of doors that the ordinary atmosphere 
would have at least enough humidity to keep the mucous membranes from drying up. Nature never provided the proper senses to go with steam-heating plants or furnaces.

When it comes to the sense of vision what havoc we have made with nature's plans! Many of us are reaping the rewards in the artificial supplements to nature which we wear to indicate the effects of indoor life on eyes. Nature ought to have attached some sort of a fatigue-recorder to eyes. As it is, we use our eyes under the nost adverse conditions. We concentrate the eyes on fine print. We try to see in dark corners for which only owl's eyes are made in nature's scheme. We sit facing the strongest light in the room. We do almost everything imaginable, just because nature never attached this fatigue-register to our eyes. We get a headache in the end, but even that is not labeled so that we may know where it came from. We squeeze our eyes literally out of shape, but the eye is the one thing the shape of which we can not see, and so we do not know it is deformed until the oculist tells us.

Finally, if we overwork with our eyes, we who teach seldom get enough exercise with the rest of our muscles. The muscles should have been provided with an exercise-gage if nature had been fitting men to do most of their work at desks. But here again nature prepared the simpler methods of knowledge to fit the simpler stages of life, and left us to work out the more complex problems of our more complex life with higher forms of knowledge.

I hardly need to dwell longer on these lines of con- 
sideration. If you will not see that a higher form of knowledge is demanded of you than that whieh eomes to you through your senses, then further argument will not eonvinee you. And as to the means of ineeting all these limitations, you are referred to the very excellent treatises now in existenee on personal hygiene and sehool hygiene. We ean not go into the details of this study now. 'The study of one's own nature gives many hints as to realms of desirable knowledge beyond, and one of the natural sequents of our teaeher-study is, as I hope you see, a perusal of hygiene. Do not think you ean get on without this enlargement of your world of knowledge. You will never do your full duty as a teacher until you learn to surround your pupils with healthful eonditions of air and heat and light, and nature did not provide you with the neeessary senses to aceomplish all this without study.

Let us turn now to a second line of thought whieh has been diseussed liere and there throughout this course. What ean the teacher with all his and her regular duties, hope to do in the way of aetual study of the problems appropriate to the profession of teaehing? Generally, teaehers have been urged in answer to this question to take up some line of ehild-study.

Child-study has been something of a disappointment to the world at large. There are a few enthusiasts who seem to be satisfied with the results, but in general the results have to be reeognized as rather meager. I think one ean understand the limitations of mueh of our ehildstudy. In the first plaee there has not been enough preliminary teaeher-study. It has been the aim of this whcle book to convinee you of that and so I shall not 
dwell on this neeessary preliminary to eliild-study any, longer. The limitations of elild-study to which 1 wish to eall your attention now are those which appear in the very problems whieh have been attacked and in the methods whieh have been employed. If we could get a new view of the produetive problems and methods of this study, I believe much might yet be done for ehild-study.

One of the general problems which has been very prominent in the minds of those who have undertaken the study of children has been the problem of ascertaining the time when certain traits of character and eertain instinctive forms of aetion first show themselves in the eliild's life. Such a study of the time faets of mental development ean be undertaken only in onc of two ways. Either the history of a single ehild is earefully followed, and then the result will not be a general formula applieable to other ehildren, or a large number of eases are brought together in what is known as an average time for a whole class of children. This average time is, however, just as inapplieable to the single child as the history of the single child was inapplicable to the wholc elass. Indeed, it is a familiar prineiple of all statistical inquiry that average results hold true only for masses, not for individuals. Thus, when we say tliat the average life of man is thirty-three years, this has no meaning whatsoever for the individual. It means only that while some individuals die young and others die at an old age, the general average of all lies between the extremes. Note that we are not denying that for eertain broad general purposes there is value in statistical inquiry, but we are stating that the value of 


\section{GENETIC PSYCHOLOGY FOR TEACHERS}

such inquiries is not in their immediate utility for the teacher who deals with small numbers of children and who should, in an ideal educational system, deal with these children as individuals.

Our criticism of child-study is not, however, directed merely against the method, it is directed also against the choice of the problem. It makes very little difference after all at what moment a certain event occurs. If you want to understand the inner character of an event you must go about the study of the conditions which lie back of the event. Science is interested in the time of an event only in so far as the time helps to locate and define the underlying conditions. Law courts sometimes inquire into the time of events, but they want the time, not for itself, but for the purpose of discovering through the location in time what the causes were which produced the fact.

The only legitimate reason for inquiring what a certain child does at a certain time, or for inquiring at. what time the child shows a certain trait, is that we want to make use of this time fact in order to understand the real inner nature of the child's development. But we shall get at this problem of the inner development of the child's nature much more directly and completely if we neglect very largely the mere time facts and attack the main problem of the analysis of the child's mental nature. One can see the evil results of neglecting the analysis and seeking dates and times only. The time investigation usually gets at nothing but superficial cxpressions. Furthermore, it is a matter of practical observation that a child will, when ripe for a new step in his progressive life, frequently fail to show this fact 
by any external sign. If we are attending merely to the time problem and its superficial determinants, we shall make a twofold mistake. In the first place, we shall get our time wrong because we shall not see the inner trait in question when it first really began to exist. And in the second place, we shall be hindered in doing the most advantageous thing for the child by the absorption of our interest in the carlier or later appearance of a mental condition which we should very often not wait for but actively engage in producing. A careful examination of the disagreements that appear in the results of various studies of children, can leave little doubt that most statistical averages of children's habits contain a large number of cascs in which the extcrnal manifestation of characteristics has been delayed for a period, thus rendering the average time too late for the real demands of natural cducation, and consequently vitiating the results entirely and rendering them wholly worthless to the teacher.

The really important question for the teacher is this: What are the conditions that must be fulfilled before the mind is prepared for a new step in development? Or to make the matter concrete, suppose one is about to teach fractions, the question is not, "When is the child going to exhibit a natural interest in fractions?" It is rather, "What are the mental conditions which will make it natural for interest to arise?" The time when a phenomenon takes place is significant only in so far as the appearance of that phenomenon shows that certain conditions have already bcen fulfilled. What we must know are the conditions. If we know the conditions and can control them, we can then produce the phe- 
nomenon at such a time as we may deem appropriate. And I take it that it is in very large measure the business of educational endeavor to produee eertain proeesses of mental devclopment at a rate which is more rapid and in a way which is more economical than that in whieh the samc result would have been aeeomplished without supervision.

Sueh a knowledge of the conditions of the ehild's development ean best be gained through eoneentration of attention on some single definitc phase of mental development and through a elose analysis of the sueession of conditions aetually appearing in such devclopment. Study the way in which your children progress in writing or arithmetic, or whatever you plcase. Do not take up all these subjects in the same year, but divide the work, and concentrate cach year on one partieular eyele of growth and study it earefully and fully.

This is the sort of child-study whieh I hope may issue from our review of teaeher-study. Let the dates of nascent periods go. Never mind at what age abstract thought begins. Do not even devote yoursclves to a determination of the date when the pupils of your grade pass from the state of "savagery" into that of "barbarism." The dates will take eare of themselves if you know how to reeognize and manage the conditions of mental life at those periods.

A third line of thought which I wish to toueh upon briefly conecrns our rclations as workers in the broad field of education. We have taken up these chapters from different points of view-you from the point of view of practical school life, I from the point of view of the university student of scienee. There are some 
of you I know, for I meet sueh people in every eompany of teaehers, who look with some degree of misgiving on the universities and the work they are trying to do by way of studying edueation. And I am very sure that there are a great many university men who doubt seriously the propriety of our taking up this elose relationship with the sehools.

The faet is, universities and publie sehools have been separated by a wide breaeh ever sinee there began to be universities and eommon sehools in our oeeidental eivilization. The universities, as you know, eame first, and represented at the time of their origin, as they have down to a very reeent date, the spirit of exelusiveness and speeialization. The universities were attended by the ruling elass, and the priestly elass, and later by all those eonneeted with the so-ealled learned professions, but they were not attended by the eommon folk. The influenees that emanated from the great eenters of learning in Europe reaehed the people only in the most indirect way.

The result of this exelusiveness was twofold. In the first plaee, the universities, removed from the aetivities of eommon life, eultivated a form of study and a form of training that was highly artifieial. There eame to be a eonventional university spirit whieh in its worst forms was, and is, arrogantly boastful of its remoteness from the people. And while the universities were thus withdrawing more and more into the narrow eireles of their own exelusiveness, the effeet upon the eommon man was the eultivation of a feeling of disrespeet for an institution that did not deal more direetly with the common, praetieal affairs of life. And even to-day it is 
not difficult to find business men, and men in many other walks of life, who sneer at the university.

When the eommon school began its long struggle for establishment and reeognition, it was, in its very birth, and because of the attitude of the universities, an institution at variance with the universities. The common school came to embody the ideals of the eommon man, it fitted his needs and prepared for his workaday life. University men regarded the people's school as so fundamentally different from the university that in the older civilizations of Europe even to-day we have the spectaele of two distinct systems of education: one for the boys who expcet to attend the universities and through the universities to enter upon the professions, the other system adapted so far as may be to the non-university elass-one might almost say the antiuniversity classthe common folk.

The antithesis between university and eommon sehool has unfortunately been seen in our own land which boasts so often of its freedom from caste distinctions. To be sure, we have done more than any other nation to remove this antithesis, but we have it yet. The institution of our American edueational system which more than any other has shown the effect of this struggle between the spirit of exclusiveness on the one hand, and the spirit of practical helpfulness to the common people on the other, is our American high school.

The history of our high schools is a most remarkable educational record. The old Latin schools of colonial times were distinctly preparatory schools for the highly speeialized universities of that day. The 
common people did not attend either Latin schools or universities. But the pressure from the common schools was very great, and soon there began to arise in distinction to the Latin schools, academies and general high schools which were equipped to give the common people more advanced training than they could receive in the common schools, but in a spirit and form differing from that exhibited in the Latin schools. The public high school of to-day is a compromise between the university preparatory school, or Latin school, and the academy or general high school. Its influence has been great in remodeling our university life and in remodcling also the life of our common schools. The brcach between the plain man and the proud academic scholar has not becn healed by this high school, standing as it docs between them and reaching out toward both, but certainly the difference is less than it used to be, and compromises are easier to make, and revisions of cducational creeds more frequent, because of the influence of this high school in which we are all interested.

But while the high school has done much toward establishing unity where there was before division, yet the careful student sces all too clearly that unity and harmony are not yet at hand. The traditions of centuries are yet alive. New forms of subdivision threaten our system. The high school is not practical enough, says the plain man once more, and he endows a technical school. The university is too abstract, let us have engineering departments, and schools of agriculture and schools of forestry. And the academic man in his turn shrugs his shoulders at the new professors of "corn- 
planting and wood-ehopping," and breathes out the wail, "It is learning's deeline! Let us withdraw onee more into our aeademie exelusiveness!"

All this laek of harmony finds most emphatie expression in the views held by sehool men on the matter of the training and seeuring of teaehers. Who among us has not heard the eritieisms launehed against university graduates, who, fresh from the flights of aeademie experienee, have sometimes shown themselves deplorably ineompetent to walk along the praetieal paths of sehool life? And, on the other hand, who among us has not noted with approval the plea of this or that great edueator for the better training of teaehers, and for the more frequent attendanee of our eommon sehool-teaehers on the eourses offered by the university?

We all of us know perfeetly well that in the presence of such a fundamental laek of harmony there is no use of one party trying to put the other out of eourt. The faets are that our edueational system is not a unit and never ean be a unit as it now exists. I shall not seek to gain the ends of harmony by asking you to give up altogether your belief that there is something wrong with the university, nor shall I tell you falsely that the university is eoming to aeept your modes of thought and teaehing as its own. What I have to say is by no means as final as that, and yet it is, I believe, more hopeful for the future of American edueation than either of those propositions would be.

What is true, is that the universities are rapidly taking up the work of making a thorough study of all phases of edueation. The universities see, no less elearly 
than the teachers in the sehools, that our Ameriean system is not a unit, and they have finally been frank enough and elear-headed enough to say that the whole problem shall be opened for full examination and revision. In this task of eanvassing the whole situation, the universities ask the schools of other grades and interests to join. No intelligent word on edueational problems eseapes the eareful students of edueation in our American universities to-day. Indeed, very many of our universities have gone further. They have undertaken to organize within thenselves practical departments for the special study of education. All over the country are growing up departments of education, or teaehers' colleges, within the universities.

I ean speak only with somewhat less assurance of the spirit on your side. But I am profoundly in error if I do not observe the same tendeney among the more progressive leaders in the schools. Certain it is that the modern normal sehool is taking up its task in a mueh broader and more comprehensive way than did the normal school of a few years ago. Certain it is that the books which teaehers read in these days are not so much as they used to be mere colleetions of deviees. The indieations show elearly enough that teachers are studying education, not merely their own grade work, and not merely formal methods.

All this is more hopeful for the future than any lazy agreement between the sehools and the universities could possibly be. If the laek of unity in our Ameriean system has set us all thinking, then laek of harmony has not been by any means an unmixed evil, and laek 
of harmony will not last very long after the study and thinking begin on all sides.

What I have said in regard to universities and schools in general, I shall now take the liberty of repeating in regard to our relations to cach other. I would not seek to tell you in any dietatorial fashion how to teaeh your classes. I offer to you university-made studies on education. I want to insist that you recognize the fact that study carried on in a university may include matcrial gathered from every souree from which edueational faets ean be gathered. I wish you to understand especially that we study your kind of cdueation in the universities. I have made bold to ask you to follow the proeesses by which some of us work out our views about the sehools, and then I leave this material with you. I am quite willing to have you subjeet it to critieism. I am quite willing to have you improve upon it. As I understand it, that is the way in whieh we are to work out the salvation of American education, by eontributing eaeh the kind of material he has at hand. The main exhortation I wonld leave with you is, study edueation. I shall be glad, of eourse, if you can accept some of my lesser exhortations. But I shall not insist so much on those.

I shall, however, do my duty by my minor cxhortations as well as by my main proposition. I shall add a brief summary of each of the ehapters so that you may see the conclusions clearly after all the details have been removed. 


\section{Teacher-Study, its Scope and Aims}

In periods of change in edueational methods, teaehers often find it difficult to adjust themselves to the new order.

Teaehers need to study their own edueation at sueh times. Their own eapaeities and their own diffieulties are quite as important to understand as are the needs of their pupils.

A study of the teacher's education will also throw much light on the character of the mental development of pupils.

Some very good illustrations of the teacher's present state of mental development may be borrowed from the study of ordinary pereeption of space.

Length as we see it, depends on the character of the surroundings and on the individual's mental standards, both of which may vary. Illusions are figures whieh are so new and so complex that we interpret their lines in a way different from that in whieh we should interpret the same lines if they appeared in simpler figures. Practise with sueh complex illusory figures makes it possible to overeome entirely the illusion. Thus, it is shown by direet experiment that praetise may modify one's way of seeing lengths.

Direction and size are recognized in the same way as length.

If one can find new possibilities of self-study in sueh a simple case as this, the further pursuit of teaeherstudy certainly promises to bring to light material worthy of examination. 


\section{How Experiences are Consolidated into Inter- PRETations of Meaning}

The images that strike the eyes, and the sounds that eome into the ears, are not attended to for their own sakes, but are interpreted in sueh a way as to eoneentrate attention on their broader meanings.

Developed mental life of all forms, is constantly dealing with meanings. Sometimes the meanings attached to experiences are right, sometimes they are wrong. When wrong the distinetion between experienee and interpretation beeomes very obvious.

Education consists very largely in training in the recognition of the true meanings of experienees.

Meanings arise from experience, but they are not due to mere memory, that is, mere retention of experienees in their original forms. Meanings are consolidated experiences-experiences stripped of their unnecessary and non-essential factors and reduced to their lowest terms. Meanings ean be learned only by working over and sifting experiences for oneself. Consolidation of experience may sometimes go so far as to leave behind no possibility of revision or enlargement. This is to be avoided by a judieious combination of memory, or retention, with consolidation.

\section{The Origin of Some of our Educational IDEALS}

The absence of immediate results makes the teacher's work largely dependent on ideals. Ideals are sometimes blindly borrowed from tradition or from wholly outside sources. The teacher's ideals are to be regarded 
as consolidated social expcriences. They represent the fixed, and often unreasoned, forms of educational thought.

For cxample, it is very difficult to account rationally for many of our accepted traditions of school order and instruction.

The reform of traditions can be effected economically and advantageously only by a careful examination, first, of the grounds of present practises, and secondly, of the true foundations of rational practises.

The changes in our course of study demand most urgently such rational considcration. Naturc-study, for example, and especially manual training, can not be rejected because of any lack of agrecment with earlier traditions of school life. Perhaps it is the traditions which should be rejectcd. This is clearly the case with our traditional attitude toward bodily movement. All our modern science shows that carlier ideals were at fault in their sharp scparation of mental and bodily activity. Bodily activities parallel mental life at every point. It is nccessary for us to modify our idcas of activity so as to include certain inner activities and certain constant external activities which often escape attention.

\section{The New Ideals of Development}

The gradually disappcaring traditions of the past are making place for the new idcals of development.

Development is most fully understood in connection with the bodily life of animals and man. Individual variations from the parental type are the first steps toward development. Advantageous variations are favored by natural selection. The variations thus se- 
leeted are transmitted from generation to generation. This proeess of development ends in the adaptation of a speeies or individual to the environment.

Social habits are transmitted, not through struetures, but through imitation.

At the beginning of development an individual is neither good nor bad, he is simple unadapted to his environment. Development begins thus with possibilities of either good or bad. Our whole notion of the ehild's moral character is coming to be determined by this view.

Mental development consists in a change of a very fundamental type in the charaeter of mental aetivity.

Development is usually non-rational, that is, not guided by any eonseiousness of the ends to be attained. Such non-rational development in the child should be guided by a teacher who is eonseious of the eourse and ends of the ehild's progressive changes. The teacher thus beeomes the rationalizing factor in the pupil's mental development.

\section{Individuality, Adaptation, and Expression}

Development would not be possible if all individuals were alike; there must be variation. The highest form of individuality, the type to be eultivated in the sehool, is not attained by making all children alike, but by fostering advantageous variations and eultivating different individuals along the lines most appropriate to their various eapaeities.

Not refinement of functions, but the fitting of funetions to the environment, is the end of development. It is possible to be over-refined in certain direetions. In 
working out the ideal of adaptation, the term environment must be broadly interpreted. It should include more than merely scholastic subjects, or technical interests. Especially must the environment of the child in the schools be extended so as to include the broad social life accessible only through indirect modes of knowledge.

The modern ideal of training is that it can be attained only through activity, not througl mere receptivity. In the acquirement of knowledge, the senses are active; attention and feeling are conditioned by activity; memory and the formation of ideas are dependent on practical interests.

The activities of the child have not, up to this time, been sufficiently investigated-thus a broad field of productive study opens up to the individual teacher.

\section{The Teacien's Writing Habit}

Writing is, first of all, an organized movement. The various fingers that hold and move the pen, and also the hand, and the arm, all contribute to this movement, but they do it in such a way as to cooperate with each other in a single well-coordinated act.

The index-finger is most active in downward strokes, the thumb, and in less degree the middle finger, guiding. In upward strokes, it is the thumb that does most of the work, the two fingers guiding. Such coordinated action is the result of organization in the nervous centers. This organization is a result of gradual growth and not of arbitrary willing.

Individual differences in nervous organization show themselves in the different forms of writing, and may 
be demonstrated by means of experiments showing the different parts played by fingers and hand in different individual eases. Even in the same individual, the coordination may be modified by ehanging conditions.

An effort to develop greater regularity in the slope of one's writing brings out the fact that there is a phase of movement-a slight pronation-espeeially important in securing regularity of slope. This is not a subjeet of direct attention as a movement, but is developed through a blind series of trials and failures during whieh attention is directed ehiefly to the written lines. This brings us to the gencral question of the direetion of attention. In developed automatic writing, it is on the thought. In undeveloped writing, it is on the written forms.

\section{Racial and Individual Development of WRITING}

Racial development does not furnish any direet suggestions as to the proper sequenee of work in the school, for the child must be adapted to a wholly different environment from that whieh the raee faeed. Raeial de. velopment, however, shows the aim of development and some of its diffieulties, in sueh a way as to give indirect suggestions advantageous to the teacher.

The race began with pieture-writing. This grad, ually gave way to writing whieh imitated sound lan. guage. Ultimatcly, a sound alphabet was developed. The present forms of letters are due to a series of developments in whieh the eharaeter of the writing material, the demands for rapid, easy movement, and 
the demands for legibility, beauty, and expression, have all been opcrative.

The child's movements are at first uncoordinated, uncertain, and discontinuous. This is due to the fact that the nervous system is unorganized, and impulses are diffuscly discharged. The diffuscness appears, not only in the irregularities of hand movement, but also in the movements of head and body which accompany writing. Diffuseness is the first stage of all devclopment of movement.

Practical suggestions. Large free exercises should precede writing. Organize all the novements of all parts of the body. Give play to individual coordinations very carly, and aim at the development of these coordinations as the chicf end of the training. Make the child critical of his own writing.

The problem of the nieaning attacled to written words brings us to the next topic, Reading.

\section{The Process of Reading}

Modern methods of teaching reading aim to cultivate the ability to rccognizc meaning as rapidly as possible. This leads somctimes to a failurc to recognize the stages of the reading processes preliminary to rccognition of mcanings. And such failure to recognize the process, is all the more dangerous because in adult life the process is automatic and therefore not a subject of attention.

The process of reading is a very active process in that it requires active adjustments of the eye and active response in the organs of articulation.

The process of reading is complex in that it requires 
a recognition of the elements of words and their fusion into single wholes. This kind of mental synthesis undoubtedly comes to include, in the highest stages, not merely single words, but whole phrases.

The synthesis of elements into single wholes as we have it in the reeognition of words, gives us a eluc to the process of synthesis by which words and meanings are combined into unitary wholes. The aetive element in such a case as the latter must always include factors other than the mere articulation movement. Emotional reactions are obvious in the rate and intensity of artieulation itself and in aceompanying phenomena. Other rcaetions of a less obvious kind also appear.

Meaning ean be grasped only in terms of individual reaction. This is the lesson of practical, rather than purcly thcoretical, verbal training.

\section{The IdeA of Number}

A study of the development of the number idca shows that in its elementary form it was very aneicnt. In its fully developed form it depended on the relatively late diseovery of eertain spceial modes of numerical cxpression and manipulation.

What, then, is the specific characteristic which makes the number idea distinct from all other forms of thought? Number is an cxpression of grouping, and number proecsses are proecsses of regrouping. Thus, 7 plus 5 equals 12 , means that given two small groups, one of seven, the other of five, we may group them together in a single large group of 12. Other processes are of like eharaeter.

The number idca is distinct from any of its concrete 
applications, so that when a problem in application is presented, it calls for three distinct kinds of thought. First, a recognition of the real relations; secondly, their translation into group ideas; and finally, the manipulation of the groups according to mathematical laws.

Number is abstract. It is a mode of arrangement which may be thought of as applied to any objects whatsoever. Number processes are limited only by the demand that they be consistcnt with each other. The science of mathematics deals with the consistent modes of grouping objects.

Applied arithmetic should be reasonable in its examples. Never lose sight of the purely mathematical relations. Make your instruction cover these relations completely, and fix these relations thoroughly through drill. Develop the abstraction after starting with the concretc objects. The abstraction is the essential phase of the development.

\section{Some Limitations of our Nature}

Nature never provided us with senses suitcd to sccuring direct.knowledge of the artificial indoor environment in which we live. We must use a higher form of knowledge. We must know about proper hygienic conditions through spccial study.

Wc can not understand or direct children properly by merely noting the time when they exhibit certain characteristics. We must study the conditions that lie back of the stages of development in which we are intercstcd. This determines the proper lines of study and investigation in child-study. 


\section{GENETIC PSYCHOLOGY FOR TEACHERS}

Our American educational system is not well organized. There are signs of improvement. The most promising indications are to be found in the cooperation of universities and common schools in the study of education. 


\section{N D E X}

Abstraction, 279, 292.

Academies, 309.

Activity, 76, 147, 260.

and adaptation, 157 .

bodily and mental, 88,96 .

constant, 94 .

in devclopment, 247.

and emotions, 152.

and impression, 90.

vs. movement, 95.

negative, 95 .

sensory, 148.

Adaptation, 106, 113, 134, 197. direct, 142.

indirect, 142.

human, 143.

school, 146.

Addition, 122, 269.

Aldus, 216.

Analysis of words, 253.

Animal consciousness, 118.

Applications, 16, 32, 47, 58,

$66,67,95,132,193,225$,

233, 262, 284, 287, 292.

Arabic numerals, 267.

Arithmetic, 275.

business, 138, 277.

primitive, 266.
Arm exercises, 225.

Arm movements, 223.

in writing, $173,176,186$.

Arm-movement writing, 176.

Art, 200.

Articulation, 281 .

and reading, 242, 244.

Ascham, 78.

Atmospheric perspcetive, 42 .

Attention, 147, 150.

in writing, 190, 231.

Automatic habit of writing, 187.

Averages, 303.

Barter, 279.

Bce, 118.

Biology, 79.

Body and mind, 86 .

Breathing and mental state, 93.

Bryan, 246.

Business arithmetic, 138, 277.

Capitals, Roman, 209.

Cattell, 241.

Cellini, 45.

Chick's development, 221. 


\section{GENETIC PSYCHOLOGY FOR TEACHERS}

Child, 303. contrast with adult, 5 . recognition of size, 9 .

Childhood, variation in, 110.

Child's nature, 110, 113, 241.

Child's writing, 220.

Child-study, 4, 79, 295, 302. through recollection, $5,27$. true problem, 305.

Chinese writing, 202.

Church sehools, 77 .

Cireulation of blood, 93.

Class instruction, 133.

Color-blindness, 155.

Colors and distance, 42.

Community, tcacher's relation to, 136.

Condensation of experience, 56 . Condensed experience, inflexible, 63 .

Cousistency in grouping, 282. Contrast, 89, 91.

Coordination, disturbed, 167, 168.

center of, 166.

museular, 165.

in writing, 169.

Copy in writing, 230, 232.

Copying, 178.

Correlation of studies, 289.

Counting, 119, 270.

primitive, 265.

Criminal, 115.

Culture epoelis theory, 197.

Curriculum, 138. development of, 83 .

Cursive, 212.

Cushing, 265.
Damaseius, 44.

Darwin, 153.

Deaf-mutes, 252.

Deeimal system, 273.

Depth, 39.

Devclopment of activity, 26. and activity, 153. biological prineiple, 103. and condensation, 56 . of eoordination, 223 . of curriculum, 83 . equilibrium in, 107. extent of, 31 . idea of, 100 . individual, 109, 197-199. of M, 207. of meanings, 46 . mental, 20. of movements, 168. museular, 222. of pereeption, 11, 20, 26 . of perception of sizes, 8 . prineiples of, 6 . racial, 197-199. and retention, 56 . social, 108. stages of, $117,121$. writing, 6 .

Dewey, 101, 267.

Diffuse movement, 220.

Digestion and mental state, 93.

Discipline, arguments for, 76 . American schools, 78 . school, 110.

Diserimination, 155.

Dislike, as present meaning, 52. 
Distances, perception of, 120 . Division, $2 \pi 2$.

Dodge, 239.

Drawing, 34.

vs. writing, 218.

Drill, 60.

in arithmetic, 291.

Ear, 148.

Ears, two, 36, 53.

Education, 32, 48, 99.

through contact, 62 .

liberal, 146.

methods of, 144.

practical, 138, 146.

study of, 311 .

by use, 60 .

F.gypt, 204.

Embryology, 103.

Émile, 111.

Emotional expressions, 153.

Emotions, 151.

and activity, 152 .

English psychology, 87.

Environment, 133, 139.

immediate, 140 .

natural, 141.

social, 135.

Equation, mathematical, 269.

Erdmann, 239.

Euclid, 267.

Experience and interpretation, 56.

and meaning, 48.

Experiment, psychological, 36,

$38, \quad 88, \quad 92, \quad 119, \quad 152$,

$170,177,183,239,243$,

246.
Experimentation in psycholo$\mathrm{gy}, 21$.

Expression, 241.

of emotions, 153, 257.

and knowledge, 90.

Eye movements, 239.

in reading, 240.

Eyes, 148, 301.

moles', 105, 133.

Eyes, two, 36, 54.

Fear of horses (illustration), 51.

Feet, training of, 168.

Fine muscles, 222.

Finger movements, 175, 222.

illustrated, 172.

in writing, 164.

Fixed interpretation, 63.

Fixity of method, 67 .

Flueney in writing, 214, 231.

Foot, 108.

Form-study, 32, 276.

Fractions, primitive, 266.

Franke, $71,78,110$.

Froebel, 78.

Fusion of letters, 245.

of words into sentences, 257 .

of words and sounds, 251 .

in telegraphic language, 250 .

Games, learning, 60 .

Geography, 79, 81, 83.

Geometry, 267 .

Grouping through counting, $269,272,273,279$.

Grube method, 290.

Gulliver's Travels, 122. 
Habits, 65.

Hall, 101.

Hand, in counting, 265. training of, 109.

Hand movements, 172. in writing, 174, 175, 185.

Hansen, 242.

Harter, 246.

Heart, 92. and attention, 150.

Heredity, 105. social, 108, 126, 232.

High school, 308.

History, 57.

Huey, 239.

Humidity, 300.

Huxley, 101.

Hygienc, 302.

Ideals, borrowed, 71 . educational, 70 . professional, 73 . revision of, 82 .

Ideas, 156. and attention, 150.

Illusions, 116. of arrow-heads, 16. of circles, 17. demonstration of, 18. disappearance through practise, 24.

of interrupted line, 30 .

of filled space, 28 .

of length, 16 .

measurement of, 23.

of parallels, 30 .

of size, 13.

unnoticed, 18.
Illusions of weights, 88 .

Imitation, 125.

Impression, 153, 241.

Incidental education, 226 , 289.

Individual development, 109.

Individual variation, 104.

Individuality, 130, 132.

in writing, 228.

Indoor objects, 12.

Inflexible interpretations, 63.

Instincts, 120.

Interest, 111.

Interpretation, 48.

double, 55.

as experience, 56 .

of sounds, 54 .

in vision, 54.

Investigations for teachers, 27 , $33,102.158,192-194,263$, $292,306$.

Italics, 216.

James, 79, 99, 101, 120, 151, 260.

James-Lange theory, 151.

Jastrow, 149.

Lange, 151.

Lapses in writing, 189.

Latin school, 308.

Laurie, 76.

Learning games, 60.

Learning languages, 250.

Legibility of letters, 214.

Lehmann, 242.

Length, recoguition of, 10 . 
Lifting person, 89.

Lighting, 301.

Line, recognition of, 10 .

Localization, auditory, 37 .

Logic, 283.

Lucretius, 14.

M, the letter, 207.

Magic, 44, 45.

Manual training, 84, 139. and equipment, 85 . parents' view of, 85 . teachers' vicw of, 84 .

McLellan, 267.

Meanings, 40. of coins, 41 .

false, 43 .

vs. impression, 49.

vs. memory, illustrated, 51. museum specimens, 47. physical conditions, 91 . present, 51 .

in reading, 236.

of sentences, 258, 259 . of words, $41,47,57,256$, 259, 262.

Measurement, 267.

Medieval schools, 77 .

Memory, 50, 56, 58, 61, 291. and ideals, 74 .

vs. practical education, 60 .

as variable element, 65 . and variation, 64 . work, 59,62 .

Mind-reading, 149.

Minot, 106.

Minus quantity, 271.

Mirrors, concave, 44.
Mirrors, interpretation of, 55, 63.

Mistakes, 116.

Mole, 103.

Monks as teachers, 77 .

Mosso, 93.

Mosso's balance-board, 93.

Movement, diffuse, 220.

excessive, 224.

in school, 75 .

Multiplication, 268, 272.

Münsterberg, 244.

Muscle-reading, 149.

Nascent periods, 304.

Natural selection, 105.

Nature-study, 32.

Necromancy, 45.

Nerve-cells, 166.

Nervous centers, 166.

Non-rational developinent, 123.

Number names, 265.

Number systems, 266.

Numerals, Arabic, 267, 268. ordinal, 270.

Roman, 268.

Pain in education, 115.

Paleography, 218.

Pedagogical science, 310 .

Pedagogy, 67.

Pen, position in writing, 229.

Pen-strokes in writing, 164.

Perspective, 7 .

Petrarch, 216.

Phoenicia, 204.

Phonetic methods, 255.

Picture-writing, 199. 
Planchette, 149.

Plateau in development, 248.

Play, 73, 123.

Pleasure, 152.

Port Royal schools, 78.

Position in writing, 227 .

Posture, 94.

Practical education, 138.

Practise curve, 24, 25, 247, 249.

Prescnt meaning, 51.

Priests, ancient, 43.

Printing, 215.

Problems in arithmetic, 284, $285,294$.

Prodigy (mathematical), 117.

Pronation, 179.

Psychology of impression, 87.

Public schools, 307.

Punishment, 114.

Puritans, 77,78 .

Rational conduct, 127.

Reading, amount of, 237.

Rebus, Egyptian, 205.

Rebus-writing, 205.

Receptivity, 147.

Recognition vs. memory, 50.

Records, keeping of, 21.

Piefinement, 134.

excessive, 136.

Refor'ms in arithmetic, 288.

Review, 34, 97, 98, 128, 129, $195,234$.

Robinson Crusoe, 122.

Roman capitals, 209.

Roman schools, 76.

Round writing, 175 .

Rousseau, 78, 111, 140.
Savage, 145.

School discipline, 75, 110.

Oriental, 75.

origin, $7 \%$.

School environment, 139.

School, purpose of, 263.

Scripts, medieval, 215.

Sea-gulls, 120.

Selection, natural, 105.

Selection of movement, 224 .

Self-education, 6 .

Sense-training, 154.

Sensory activities, 148.

Sentences, meaning of, 258 .

Sight, 301.

Sizes, recognition of, 7,9 .

Skin zero, 300.

Slope of letters, 180, 184, 218.

Slope, practise on, 185.

Smell, 134, 148, 298.

Social devclopment, 108.

Social heredity, 108, 126, 232.

Solidity, 39.

Sound-writing, 209.

Space, education in, 276 .

Spatial relations, 278 .

Speech as symbolism, 204.

Speer, 276.

Speer method, 293.

Spelling, 253-255.

Spelling-book, 236.

Spencer, 58, 145.

Statistical method, 303.

Stevenson, 69.

Subtraction, 270.

Summary:

Chapter I, 313.

Chapter II, 314. 
Summary:

Chapter III, 314.

Chapter IV, 315.

Chapter V, 316.

Chapter VI, 317.

Chapter VII, 318.

Chapter VIII, 319.

Chapter IX, 320 .

Chapter X, 321.

Superstition as interpretation, $43,49$.

Syllables distingnished, 206.

Symbolic writing, 202.

Systems of number, 266.

Systems of penmanship, 162.

Tact, 60 .

Taste, 148.

Teacher as rationalizing factor, 124.

'Teachers' colleges, 311 .

'leachers, training of, 60, 310 .

Tcacher-study, 3, 34, 192, 295, 302.

Telegraphic language, 245.

Telepathy, 242.

Temperature sense, 299.

Ten, 273.

Tests, 69 .

Touch, 149.
Tradition and ideals, 74 .

Transmission, 105.

'Tutors, 133.

Uncials, 213.

Undeveloped movements, 168.

Universities, 307.

Unpleasant experiences, 152.

Value, idea of, 42.

Value, physical conditions, 91.

Variation, 129, 131.

individual, 104.

Ventilation, 298.

Vertical writing, 175.

Walking, 20, 188.

Wallace, 120.

Whispering, unconscious, 243.

Word-method in reading, 252255.

Words, and letters, 245.

meaning of, 259,262 .

recognition of, 240 .

written, 174.

Writing, 161.

by pictures, 199.

records, 172, 174, 176.

teaching of, 125 .

Wundt, 295. 



\section{The Standard Professional Library for Teachers}

Edited by WILLLAM T. HARRIS, A. M., LI. D.,

United States Commissioner of Education.

$12 \mathrm{mo}$, cloth, uniform binding.

35. The Intellectual and Moral Development of the Child, by Gabriel Compayré. . . . . . . . . $\$ 150$

36. Herbart's A B C of Sense-Perception, by Williay J. Eckoff, Ph. D., Pd. D. . . . . . . . . . . . 150

37. Psychologic Foundations of Education, by Williax T. HARkis, A.M., LL. D., United States Commissioner of Education.

38. History of the School System of Ontario, by G. W. Ross, LL. D., Minister of Education, Ontario, Canada. .

39. Principles and Practice of Teaching, by Jayes Jonon-

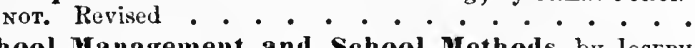

40. School Management and School Methods, by Josepu

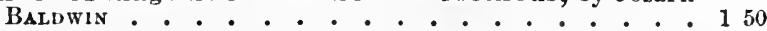

41. Froebel's Laws for all Teachers, by Janes L. Huones 150 42. Bibliography of Education, by WiLL H. Monroe . . 200 43. The study of the Child, by AleERT R. TAYLOR, Ph. D. 125 44. Education by Development, by Friedrici Froebel. Translated by Josepuine Jarvis . . . . . . . . . 150

45. Letters to a Mother, by Srsan E. Blow . . . . . . 150

46. Montaigne's The Education of Children, edited by L. E. Rector

47. The Secondary School System of Germany, by FREDERick E. Bolton, Ph. D.

48. Advanced Elementary Science, by Edward G. Howe .

49. Dickens as an Educator, by James L. Huanes . . .

50. Principles of Education Practically Applied, by JaMes M. Greenwood. Revised . . . . . . . . 100

51. Student Life and Customs, by M. D. Sneldon, Ph. D., net, 120

52. All Ideal School, by Preston W. Searci . . . . net, 120

53. Later Infancy of the Child, by Gabriel Conpayré. 'Translated by MARY E. WILson, (Part II of Vol. 35), net, 120

54. Educational Foundations of Trade and Industry,

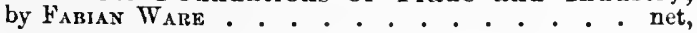

55. Genetic Psychology for Teachers, by Charleg II. JoDd, Ph. D. . . . . . . . . . . . . . . net, Others in meparation.

D. APPLETON AND COMPANY, NEW YORK. 


\section{INTERNATIONAL EDUCATION SERIES.}

\section{Dickens as an Educator.}

By James L. Hughes, Inspector of Schools, Toronto. Vol. 49. $12 \mathrm{mo}$. Cloth, \$1.50.

\section{Adopted by the Indiana State Teachers' Reading Circle.}

All teachers have read Dickens's novels with pleasure. Probajly few, however, have thought of him as a great educational reformer. But Inspector Hughes demonstrates that such is his just title. U.S. Commissioner William T. Harris says of "Dickens as an Educator": "This book is sufficient to establish the claim for Dickens as an educational reformer. He has done more than any one else to secure for the child considerate treatment of his tender age. Dickens stands apart and alone as one of the most potent influences of social reform in the nineteenth century, and therefore deserves to be read and studied by all who have to do with schools, and by all parents everywhere in our day and generation." Professor Hughes asserts that "1)ickens was the most profound exponent of the kindergarten and the most comprehensive student of childhood that England has yet produced." The book brings into connected form, under proper headings, the educational principles of this most sympathetic friend of children.

"Mr. James L. Hughes has just published a book that will rank as one of the finest appreciations of Dickens ever written."-Colorado School Fournat.

"Mr. Hughes has brought together in an interesting and most effective manner the chief teachings of Dickens on educational subjects. His extracts make the reader feel again the reality of Dickens's descriptions and the power of the appeal that he made for a saner, kindlier, more inspiring pedagogy, and thus became, through his immense vogue, one of the chief instrumentalities working for the new education." -Wisconsin fournal of Education.

D. APPLETON AND COMPANY, NEW YORK. 


\section{INTERNATIONAL EDUCATION SERIES.}

\section{Principles of Education Practically Applied.-Revised.}

\section{By James M. Greenwood, Superintendent}

of Schools, Kansas Cicy, Mo. Vol. 50. \$1.00.

This eminently practical book assumes that education is a science; that school-teachers can understand the principles of this science; and that in their daily work they can apply these with unerring certainty to the children under their control. The teacher is told plainly what to do as well as what to avoid. The directions therefore are simple, pointed, and emphatic.

Since the original publication of this book (1887) some methods, then foreshadowed, have been worked out in detail, such as the teaching of arithmetic, geography, and United States history. In this revised edition several chapters have been recast to indicate the best methods, while the spirit and general tone of helpfulness in the first edition have been preserved intact.

The author's independent and alert observations will be found an invaluable aid to the practical teacher, not only in the matter of inventing successful devices, but in seeing the eternal principles that form the basis of intelligent criticism.

The book deals with school and class management; the conduct of recitations; the art of questioning; methods of teaching reading, composition, language, penmanship, geography, history, and arithmetic. There is an extremely sensible chapter on Health and Hygiene, and the volume closes with "Only a Boy," a bright and suggestive study of familiar types.

D. APPLETON-AND COMPANY, NEW YORK. 


\section{INTERNATIONAL EDUCATION SERIES.}

\section{Student Life and Customs.}

By Henry D. Sheldon, Ph. D., Professor of the University of Oregon. Vol. 5I. 12mo. Cloth, \$1.20 net; postage 9 cents additional.

A fascinating and delightful book has been made by writing a history of student life as seen from the inside. Nearly all that is here contained concerns the reaction of the student against the strict regime imposed upon hima régime that threatens to destroy his individuality and to make him a puppet. Dr. Sheldon's book covers the entire history of university life from the Middle Ages down to I9OI, with a review of past and present student bodies, classes, societies, fraternities, religious organizations, and self-governing clubs. There are an elaborate bibliography and index. Every university and college and secondary student, and especially every teacher, will find this work of exceeding interest, while it is sure to touch a responsive chord in the heart of every alumnus. It forms a general introduction to the subject, and the facts collected in it will be of service to that group of pedagogical thinkers which, since Froebel, has made spontaneity the touchstone of educational progress. Throughout, the book deals with the utilization of the play instinct ; and it is thus connected in the most constructive and practical way with the present interest in genetic psychology and child study.

"A work of live interest to both students and educators. The distinguishing features of student life in medieval universities with all its romance and wild freedom, often degenerating into license, is interestingly told. Of nearer interest to the modern student is the sketch of the development of the American college and the origin and rise of the various elements that make student life what it is to-day. On its historical side, the stirring romance and color of student life will appeal to the general reader, and as a careful pedagogical study the book has a genuine educational value." - Wisconsin Fournal of Education.

D. A P PLETON A N COMPANY, NEW YORK. 


\section{INTERNATIONAL EDUCATION SERIES.}

\section{An Ideal School; or, Looking Forward.}

By Preston W. Search, Honorary Fellow in Clark University. With an Introduction by Pres. G. Stanley Hall. Vol. 52. 12mo. Cloth, \$1.20 net; postage 10 cents additional.

"I am not concerned that the things presented in this little constructive endeavor will not find bodily incorporation in schools; for it is cross-fertilization and not grafting that has given us our richest varieties of fruits and flowers. This work is an attempt at spirit, not letter ; at principle, not method."-From the Author's Preface.

"A book I wish I could have written myself; and I can think of no single educational volume in the world-wide range of literature in this field that I believe so well calculated to do so much good at the present time, and which I could so heartily advise every teacher in the land, of whatever grade, to read and ponder."-Pres. G. Stanley Hall, Clark University.

"It is to my mind the most stimulating book that has appeared for a long time. The conception here set forth of the function of the school is, I believe, the broadest and best that has been formulated. The chapter on Illustrative Methods is worth more than all the books on 'Method' that I know of. The diagrams and tables are very convincing. I am satisfied that the author has given us an epoch-making book."-Henry H. Goddard, Ph. D., State Normal School, West Chester, $\mathrm{Pa}$.

"I received a copy of 'An Ideal School,' and I am satisfied that I made no mistake when $I$, with the other two members of the book committee, recommended the book to the 3 1o teachers in our county."J. G. Dundore, Lycoming County, Pennsylvania.

"Certainly one of the most notable books on education published in many years."-P. P. Claxton, Editor Atlantic Educational Journal.

"You have done the cause of real education an important service. This book is, in my opinion, one of the most useful in the International Education Series."-Albert Leonard, Editor of the Journal of Pedagogy.

D. APPLETON AND COMPANY, NEW YORK. 


\section{INTERNATIONAL EDUCATION SERIES.}

\section{Educational Foundations of Trade and Industry.}

By Fabian Ware. Vol. 54. Price, \$1.20 net; postage 10 cents additional.

This timely book describes the educational foundations of trade and industry as exhibited in the school systems of the chief European peoples and of the United States.

The promotion of industry through education is the burden of the author's appeal. To make this appeal effective, he examines first the growth of national systems in general-their conditions, impulses, and directions. This leads to a series of chapters giving a detailed statement of the educational foundations laid in England, Germany, and France; and finally, those in America.

The section devoted to the United States gives an exhaustive résumé of the characteristics of American education, from the kindergarten to the graduate university. Since Mr. Ware treats the subject more on its practical than on its cultural side, his examination includes a thorough analysis of commercial and technological education in every aspect and branch. The latest information has been used, and a large amount of concrete illustration, drawn from the actual workings of individual schools, gives the argument freshness, clearness, and coherence.

"There can be no doubt that Mr. Fabian Ware's book will be of even more interest to Americans than to the English readers for whom it was primarily written. It is strictly up to date, and in view of the discussions that have recently taken place on the failure of England to keep her place in the race for trade and manufacturing supremacy, Mr. Ware has some observations to make that have a strong bearing on the subject."-New York Sun.

D. APPLETON AND COMPANY, NEW YORK. 





\section{UNIVERSTTY OF TORONTO}

\section{LIBRARY}

$\stackrel{3}{0}$

$\Leftrightarrow 2$

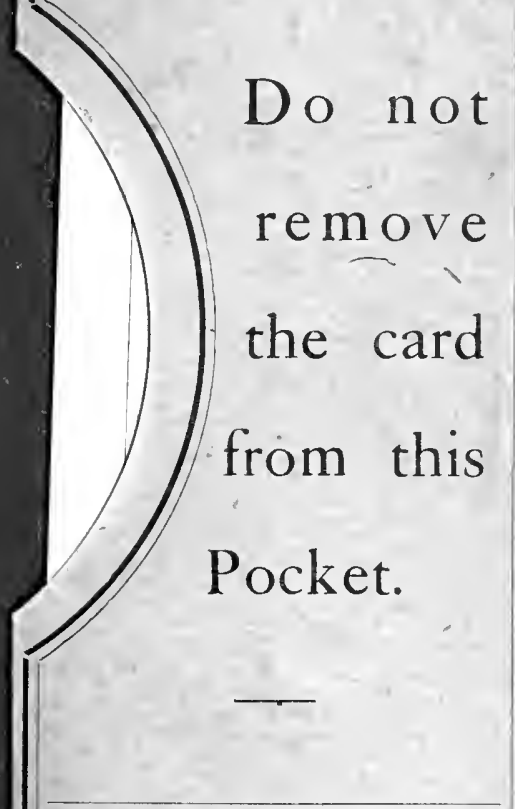

Acme Library Card Pocket

Under Pat. "Ref. Index File."

Made by LIBRARY BUREAD, Boston 


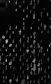

